UNIVERSIDADE DE SÃO PAULO

FACULDADE DE ECONOMIA, ADMINISTRAÇÃO E CONTABILIDADE DEPARTAMENTO DE CONTABILIDADE E ATUÁRIA PROGRAMA DE PÓS-GRADUAÇÃO EM CIÊNCIAS CONTÁBEIS

MENSURAÇÃO DO RISCO SISTÊMICO NO SETOR BANCÁRIO COM UTILIZAÇÃO DE VARIÁVEIS CONTÁBEIS E ECONÔMICAS

Lucio Rodrigues Capelletto

Orientador: Prof. Dr. Eliseu Martins

SÃO PAULO 
Profa. Dra. Suely Vilela

Reitora da Universidade de São Paulo

Profa. Dra. Maria Tereza Leme Fleury

Diretora da Faculdade de Economia, Administração e Contabilidade

Prof. Dr. Reinaldo Guerreiro

Chefe do Departamento de Contabilidade e Atuária

Prof. Dr. Fábio Frezatti

Coordenador do Programa de Pós-Graduação em Ciências Contábeis 


\section{MENSURAÇÃO DO RISCO SISTÊMICO NO SETOR BANCÁRIO COM UTILIZAÇÃO DE VARIÁVEIS CONTÁBEIS E ECONÔMICAS}

Tese apresentada ao Departamento de Contabilidade e Atuária da Faculdade de Economia, Administração e Contabilidade da Universidade de São Paulo como requisito para a obtenção do título de Doutor em Ciências Contábeis.

Orientador: Prof. Dr. Eliseu Martins

\section{SÃO PAULO}


Tese defendida e aprovada no Departamento de Contabilidade e Atuária da Faculdade de Economia, Administração e Contabilidade da Universidade de São Paulo - Programa de Pós-Graduação em Ciências Contábeis, pela seguinte banca examinadora:

\section{FICHA CATALOGRÁFICA}

Elaborada pela Seção de Publicações e Divulgação do SBD/FEA/USP

Capelletto, Lucio Rodrigues

Mensuração do risco sistêmico no setor bancário com utilização de variáveis contábeis e econômicas / Lucio Rodrigues Capelletto. -- São Paulo, 2006.

$260 \mathrm{p}$.

Tese (Doutorado) - Universidade de São Paulo, 2006

Bibliografia.

1. Crise bancária 2. Crise financeira 3. Risco 4. ContabilidadeIndicadores I. Universidade de São Paulo. Faculdade de Economia, Administração e Contabilidade II. Título. 
A Deus, pela oportunidade de uma vida saudável.

A minha família, na qual encontrei incondicional apoio e incentivo à consecução deste trabalho, especialmente a minha querida esposa Márcia, adoráveis filhos Anna Carolina, Luís Vinícius e João Victor, e admirável mãe Enaura.

Ao Professor Dr. Eliseu Martins, meu orientador, pela confiança, atenção e orientação técnica ao longo de todo processo de elaboração deste estudo, bem como pelos valiosos ensinamentos sobre Contabilidade.

Ao corpo docente do programa, especialmente aos Professores Doutores Luiz Nelson Guedes de Carvalho e Luiz João Corrar que compartilharam seus conhecimentos e realizaram observações oportunas e significativas para a melhoria do estudo.

Ao Prof. Dr. Gilberto Martins, pela oportunidade de apresentar o estudo no fórum de discussões metodológicas, no qual foram realizadas valiosas sugestões e críticas.

Ao Professores Doutores Otávio Ribeiro de Medeiros, Paulo Roberto Barbosa Lustosa e César Augusto Tibúrcio Silva, todos da Universidade de Brasília, pelas relevantes contribuições apresentadas ao projeto do estudo.

Aos amigos Antonio Carlos Coelho, Amaury José Rezende, Bruno Salotti, Giovani A. Silva Brito, Huang Chien En, Jaime Gregório, Jorge Eduardo Scarpin, Marcial Tadeu Borelli, Márcio Luiz Borinelli, Ricardo Lopes Cardoso e Roberta Carvalho de Alencar, bem como aos demais colegas, pela extraordinária convivência e importante troca de conhecimentos que propiciaram a construção de um aprendizado sólido e de qualidade. Aos funcionários do Departamento de Contabilidade e Atuária da Faculdade de Economia, Administração e Contabilidade USP, pela eficiência profissional e camaradagem.

Ao Banco Central do Brasil, pela manutenção do Programa de Pós-Graduação-PPG, que viabilizou a participação no curso. Aos colegas do Banco Central, especialmente ao Vânio César Pickler Aguiar e Cornélio Farias Pimentel, pelo incentivo, apoio logístico e colaboração ao fornecimento de dados necessários à execução do estudo. Igualmente, aos colegas Benjamin Tabak, orientador técnico, André Luiz Caccavo Miguel, César Viana Antunes de Oliveira e José Reynaldo de Almeida Furlani, pelas informações prestadas. Ao Diretor Geral da Faculdade Michelangelo, Stuart do Rêgo Barros Carício, pelo incentivo e auxílio financeiro para realização do curso.

Aos supervisores bancários dos países componentes da amostra e especialmente à Silvia Ramirez, do IMF, pelo envio de dados e observações pertinentes ao estudo. 
“A definição de insanidade é fazer sempre a mesma coisa e esperar um resultado diferente”

Albert Einstein 


\section{RESUMO}

O nível de risco sistêmico no sistema financeiro tem sido objeto de constante preocupação no âmbito de organismos internacionais e autoridades de supervisão. As crises financeiras ocorridas em países da América Latina, do Sudeste Asiático, na Rússia, e em diversos outros, causaram vultosos prejuízos econômicos e custos sociais elevados. As pesquisas referentes ao assunto têm buscado encontrar características comuns que possam sinalizar antecipadamente a proximidade dessas crises. Até o momento, as variáveis utilizadas são de natureza econômica, como reservas internacionais, taxa de câmbio e endividamento externo de curto prazo. Frente a essa constatação, este estudo buscou mensurar o nível de risco sistêmico no setor bancário com a utilização de variáveis contábeis e econômicas. Por meio das variáveis econômicas, relativas às taxas de juros e de câmbio, e das variáveis contábeis, representativas da qualidade do crédito e da liquidez, foi possível construir indicadores de riscos que, juntamente com outros de natureza puramente contábil, foram submetidos à análise de regressão logística, a fím de verificar a significância estatística desses indicadores, bem como a existência de modelos capazes de aferir a probabilidade de determinado sistema bancário ser classificado como suscetível ou não à ocorrência de crise. Os resultados alcançados revelaram a existência de indicadores contábeis e de riscos capazes de discriminar os sistemas bancários dos países componentes da amostra pelo nível de risco. As variáveis contábeis e econômicas mais associadas à ocorrência de crises são relacionadas com a qualidade dos créditos, o volume de resultados e o nível de taxa de juros. Todos os indicadores construídos com base nessas variáveis foram identificados como relevantes no processo de classificação, destacando-se os relacionados à volatilidade da inadimplência, à volatilidade da rentabilidade e à volatilidade da taxa de juros, assim como à média da rentabilidade e à média do risco de crédito. Corroborando essa evidência, as equações compostas pelos indicadores citados apresentaram percentuais de acerto nas classificações superiores a $90 \%$. Adicionalmente à correta separação dos grupos, as classificações dos países foram ponderadas pelo índice de risco sistêmico (IRS), que expressa a probabilidade de pertencer a determinado grupo. $\mathrm{O}$ ordenamento dos países pelo grau de risco sistêmico no setor bancário fornece parâmetro de comparação significativo para a tomada de decisão calibrada à exigência de cada situação. Por meio dele, é possível saber qual país apresenta maior ou menor risco sistêmico. Além disso, o acompanhamento dos IRS de um país no tempo expõe as tendências e os pontos críticos, os quais servem de subsídios à atuação das autoridades responsáveis pela estabilidade e funcionamento do sistema, tanto do país em foco como dos países relacionados.

Palavras-chave: crise bancária, crise financeira, risco, contabilidade - indicadores. 


\begin{abstract}
The systemic risk in the financial system has been a constant concern for the international institutions and supervisory authorities. The financial crises occurred in Latin America, Southeast Asia, Russia, and other countries, have caused significant economic damages and high social costs. The related researches have tried to find common characteristics able to early warn the proximity of crises. Up to now, the variables that have been used come from economic features, like international reserves, foreign exchange rate, and external debt. Considering the high correlation between the financial system and the economic health, the objective of this study is to measure the systemic risk of the banking system, utilizing accounting and economic variables together. Through the volatilities of economic variables, like interest rate and foreign exchange rate, and accounting variables, representatives of credit quality and liquidity, it was possible to build indicators comprising risk factors. These indicators, added to simple accounting indicators, were submitted to logistic regression analysis, in order to test the statistic significance of them, and to verify the existence of a model to evaluate the probability of any banking system be classified as susceptible, or not, to financial crises. The results exposed the existence of accounting and risk indicators capable to discriminate banking systems according to the risk level. The accounting and economic variables most associated to financial crises are related to credit quality, earnings, and interest rate level. All of indicators composed by these variables showed to be relevant in the classification process, highlighting those related to the volatility of non-performing loans, profitability, and interest rate, as well those representatives of the profitability and credit risk means. Confirming that, the equations resulted in correct classification above $90 \%$. In addition to the correct segregation between groups, the countries classifications were weighted by the systemic risk index (IRS), which expresses the probability to become to each group. The classification of countries by the level of systemic risk provides parameters for comparison of situations and to take actions adjusted to the severity of each one. Through these indexes (IRS), it is possible to recognize which country has more or less systemic risk, and to monitor trends and critical points, which are so important to the authorities responsible for the financial system stability.
\end{abstract}

Keywords: banking crises, financial crises, risk, accounting - indicators. 


\section{SUMÁRIO}

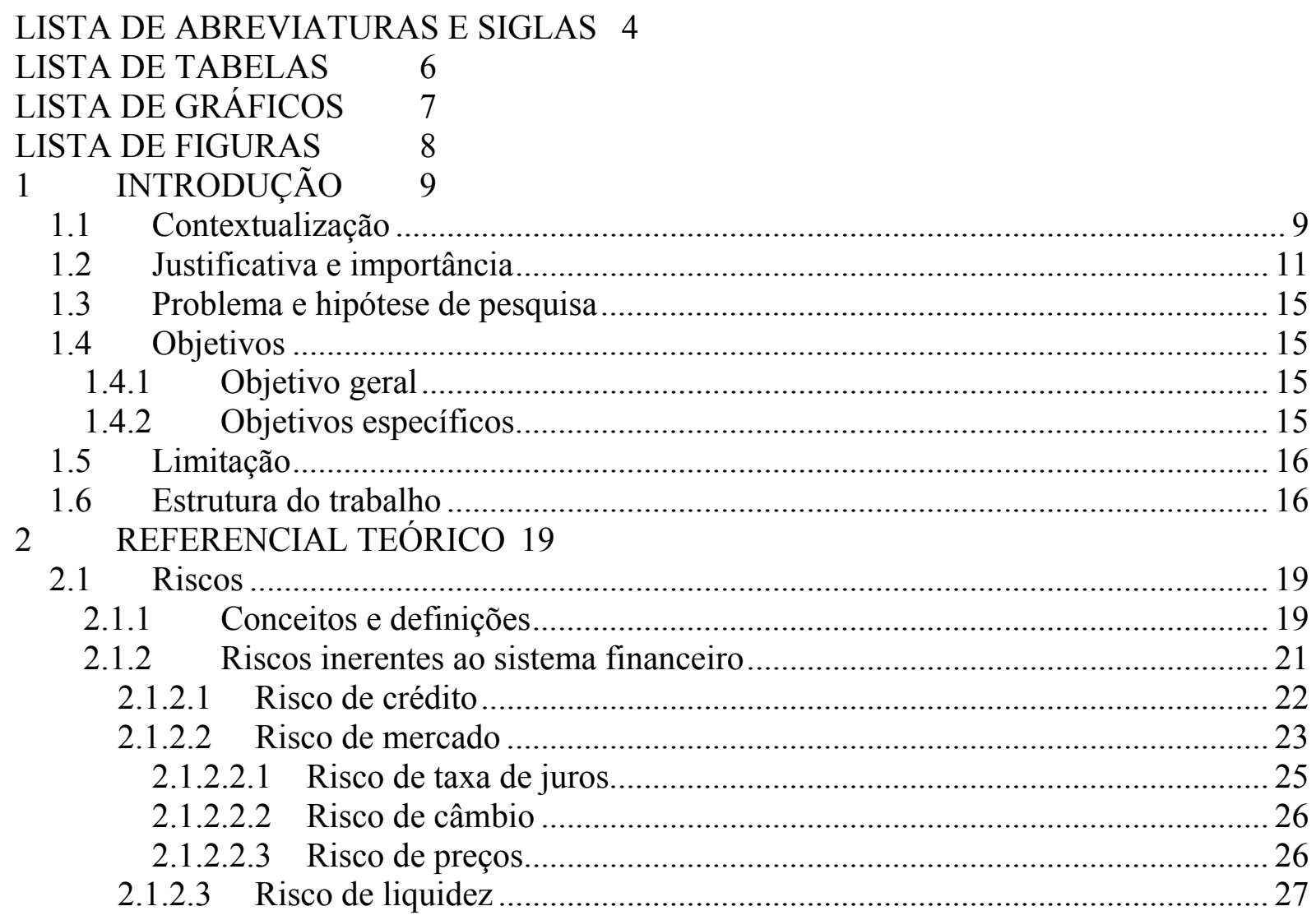

2.1.3 Risco sistêmico................................................................................ 28

2.1.4 Fundamentação do Patrimônio líquido como referência à cobertura de riscos 31

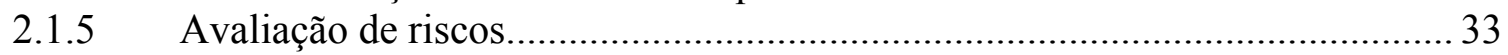

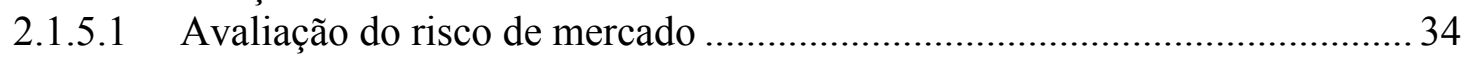

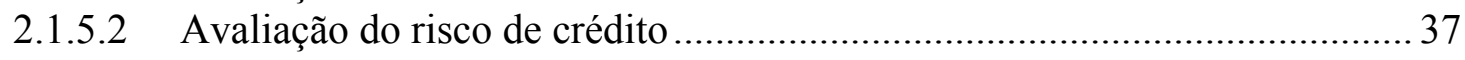

2.1.6 Diferenciação entre perda esperada e não-esperada........................................ 39

2.2 Variáveis econômicas e contábeis para avaliar riscos ................................................ 41

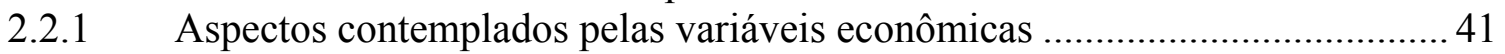

2.2.2 Aspectos contemplados pelas variáveis e indicadores contábeis .................... 45

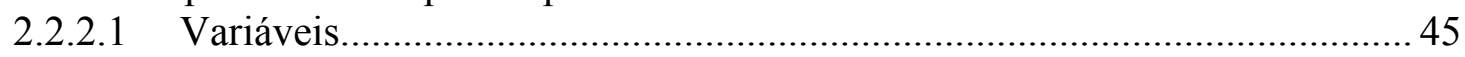

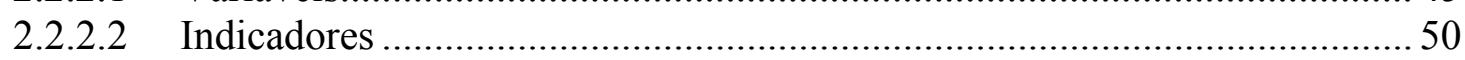

2.2.3 Relação entre o sistema financeiro e as variáveis econômicas ......................... 52

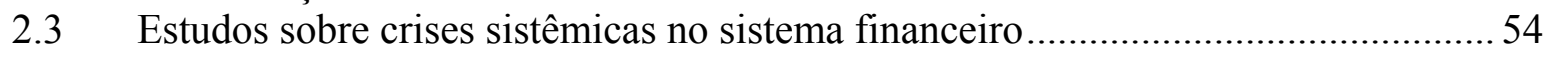

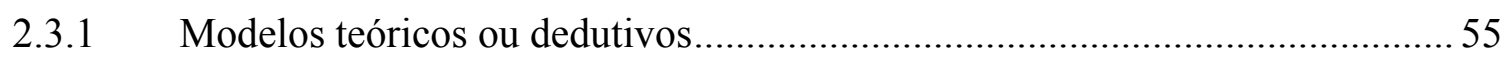

2.3.1.1 Modelo baseado nos fundamentos econômicos ........................................... 56

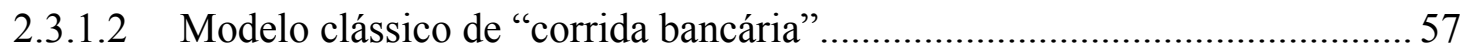

2.3.1.3 Modelos de "corrida bancária" e ciclos de negócios......................................5 58

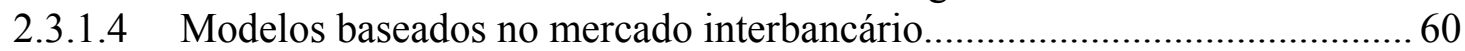

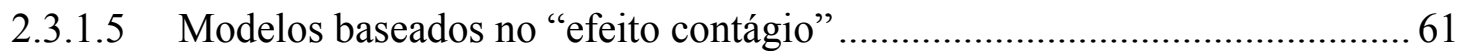

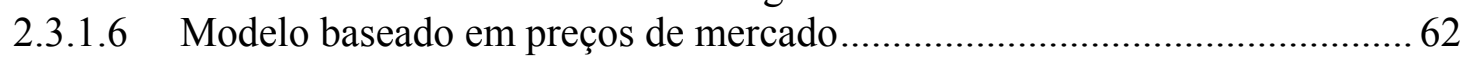

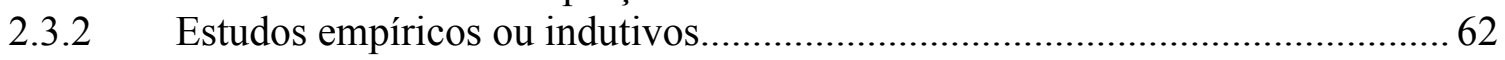

2.3.2.1 Estudos com utilização de técnicas de análise multivariada ........................63

2.3.2.2 Estudos com utilização da técnica "extração de sinais" ............................... 66

2.3.2.3 Variáveis e indicadores relevantes em outros estudos ................................6 68 


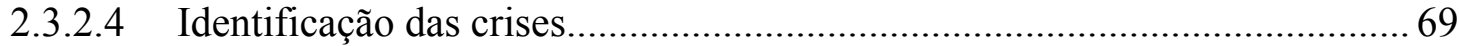

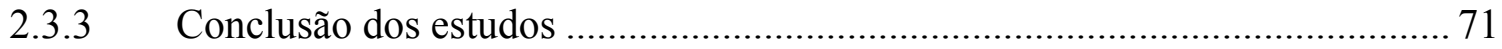

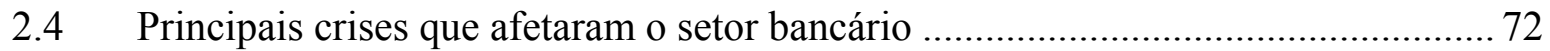

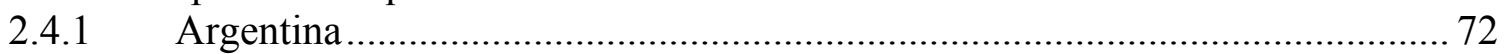

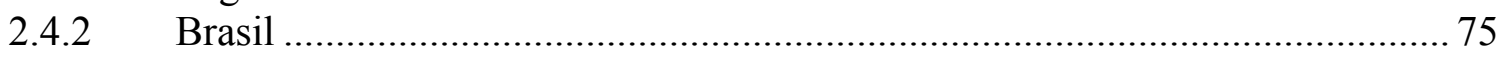

2.4.3 Coréia do Sul, Indonésia, Tailândia, Filipinas e Malásia (Sudeste Asiático) .. 78

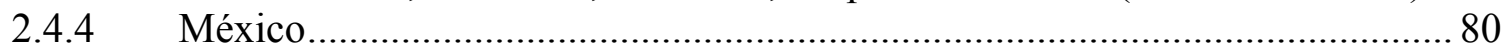

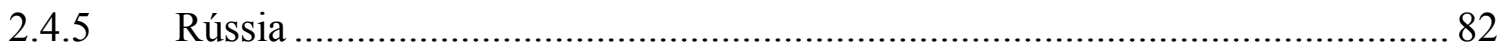

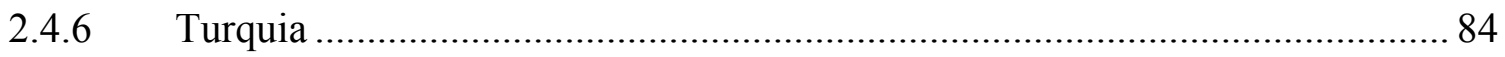

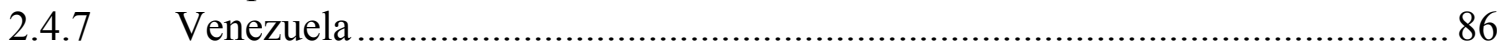

2.4.8 Considerações sobre as experiências de crises financeiras ............................... 87

3 METODOLOGIA DA PESQUISA 89

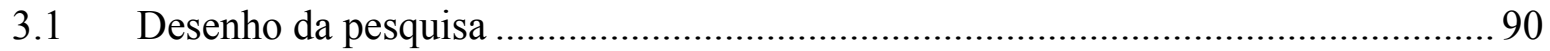

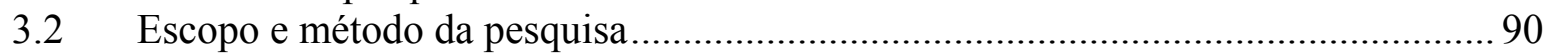

3.2.1 Composição da amostra e identificação das crises.......................................... 91

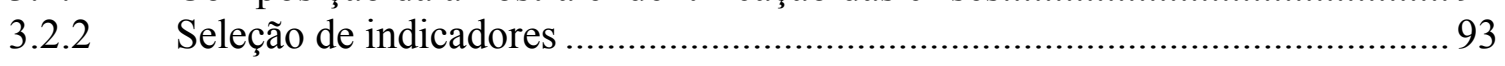

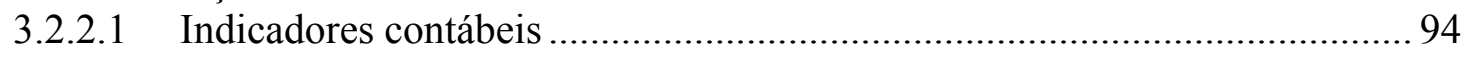

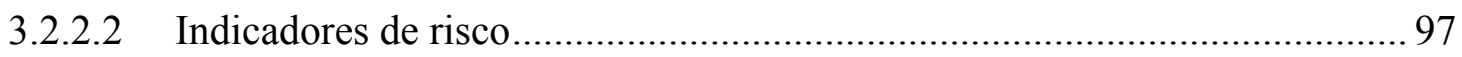

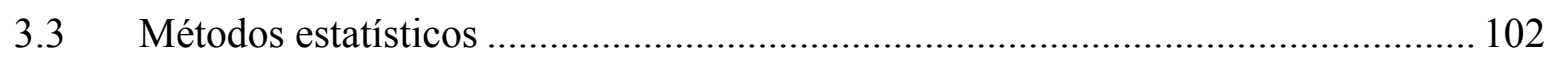

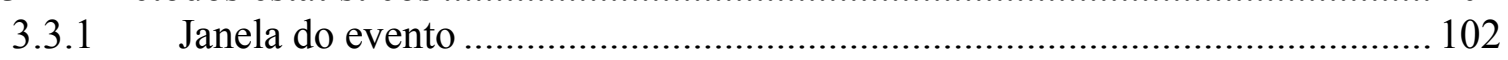

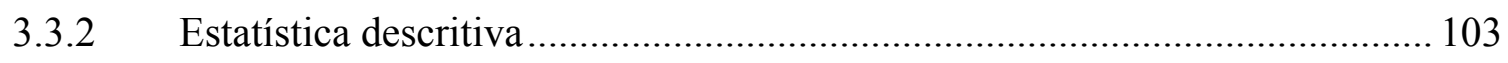

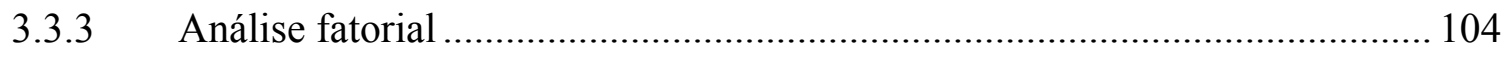

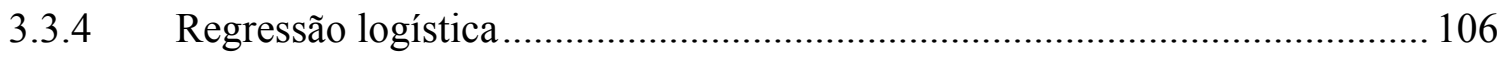

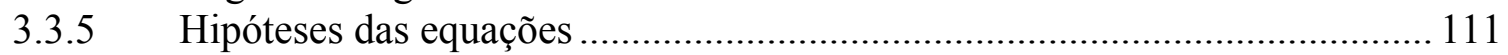

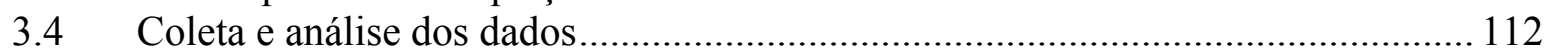

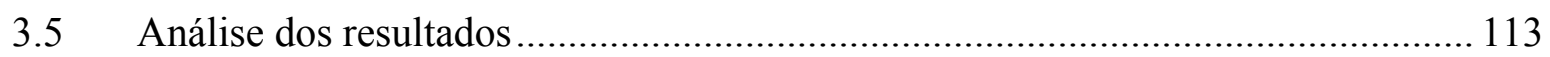

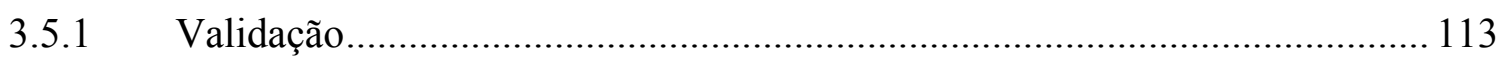

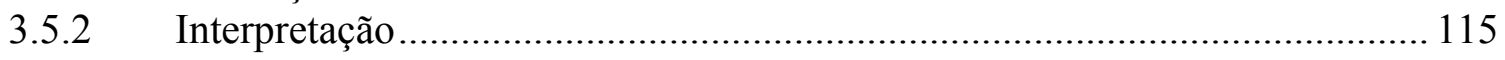

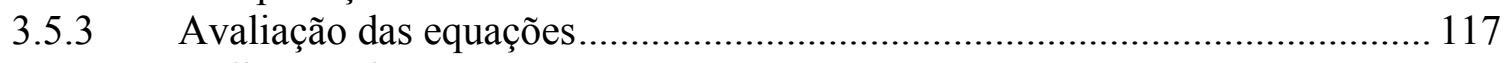

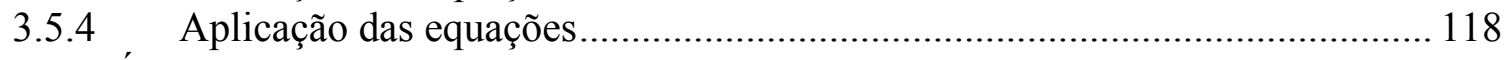

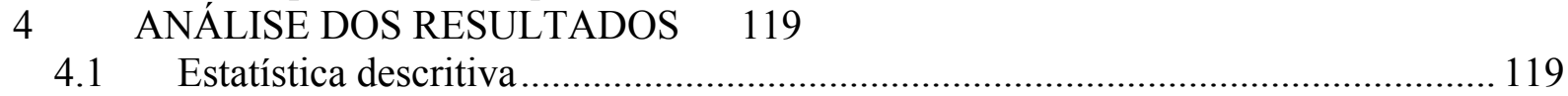

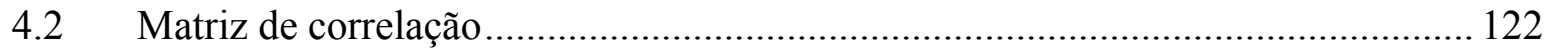

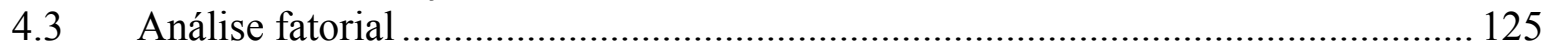

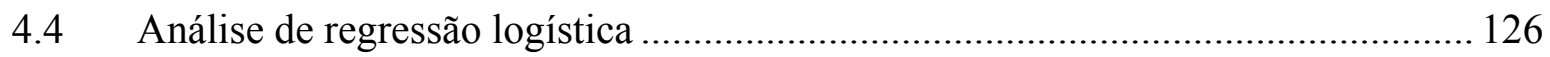

4.4.1 Coeficientes de variação........................................................................ 127

4.4.1.1 Validação do modelo e significância de todos os indicadores .................... 127

4.4.1.2 Validação do modelo e significância dos indicadores contábeis ................ 132

4.4.1.3 Validação do modelo e significância dos indicadores de riscos .................. 133

4.4.1.4 Modelo com utilização de indicadores representativos dos coeficientes de

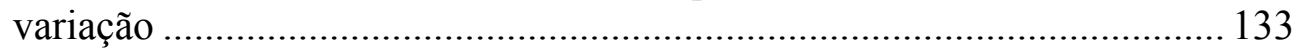

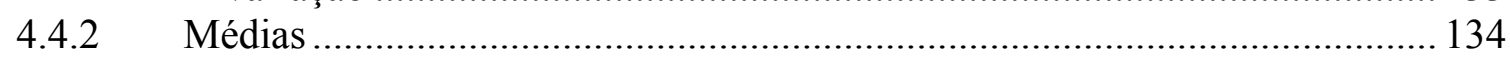

4.4.2.1 Validação do modelo e significância dos indicadores ............................... 134

4.4.2.2 Validação do modelo e significância dos indicadores contábeis e de riscos

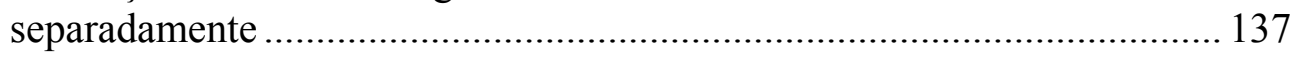

4.4.2.3 Modelo com utilização de indicadores representativos das médias ........... 137

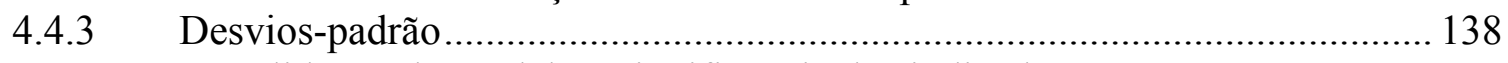

4.4.3.1 Validação do modelo e significância dos indicadores ............................... 138

4.4.3.2 Validação do modelo e significância dos indicadores contábeis e de riscos separadamente..... 
4.4.3.3 Modelo com utilização de indicadores representativos dos desviospadrão

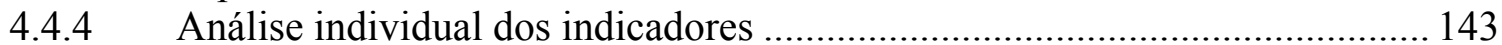

4.4.5 Interpretação dos resultados da análise de regressão logística....................... 144

5 AVALIAÇÃO E APLICAÇÃO DAS EQUAÇÕES 149

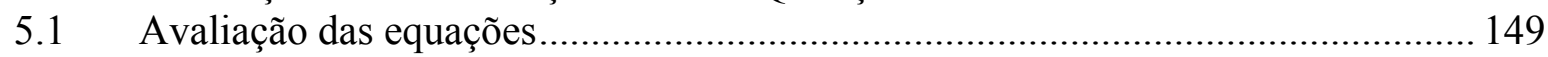

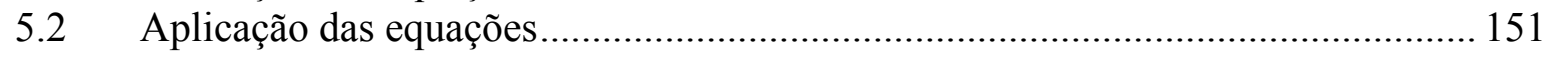

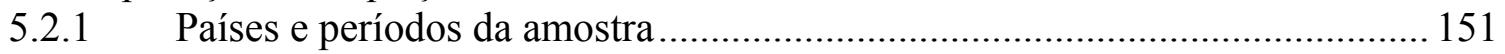

5.2.1.1 Exemplo de aplicação das equações..........................................................152

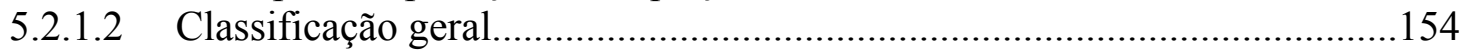

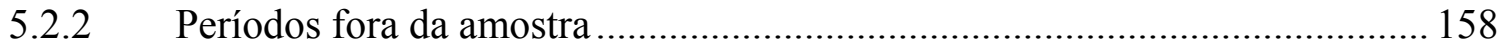

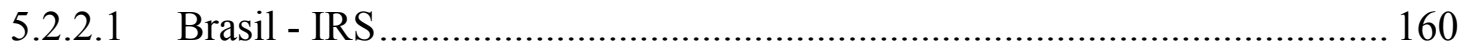

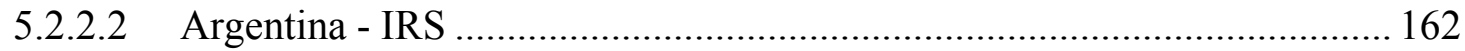

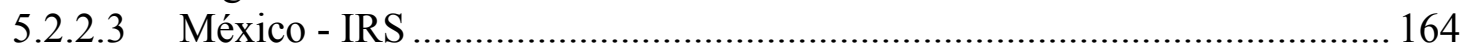

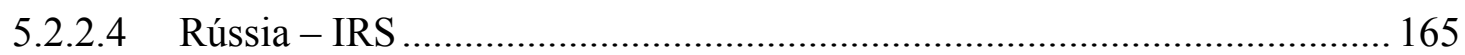

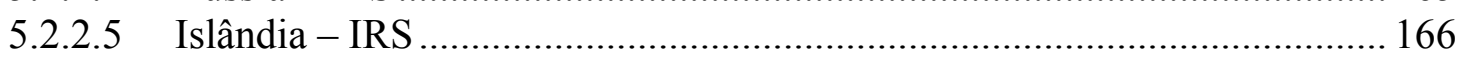

5.2.2.6 Tailândia - IRS............................................................................. 167

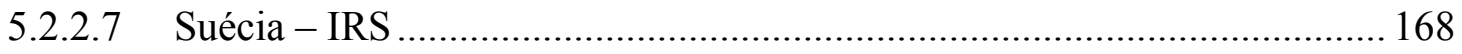

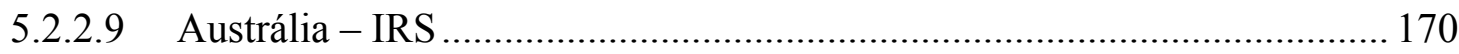

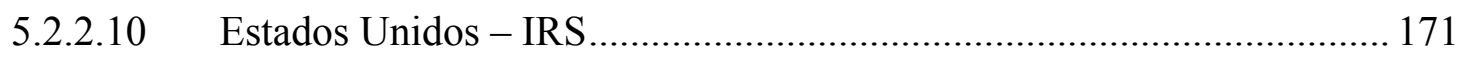

5.2.3 Considerações sobre a aplicação das equações .............................................. 171

6 CONCLUSÃO 173

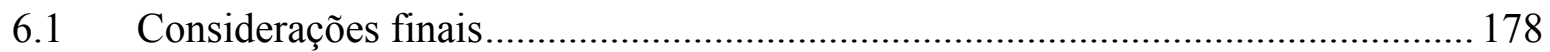

REFERÊNCIAS 179

APÊNDICES 191

ANEXOS 243 


\section{LISTA DE ABREVIATURAS E SIGLAS}

AL: Ativo líquido

ANDIMA: Associação Nacional das Instituições do Mercado Financeiro

APT: Asset pricing theory

AT: Ativo total

ASBA: Associação de Supervisores Bancários da América Latina

BC: Banco central

BCB: Banco Central do Brasil

BCBS: Basel Committee on Banking Supervision (Comitê de Basiléia sobre Supervisão Bancária)

BID: Banco Interamericano de Desenvolvimento

BIRD: Bank for International Reconstruction and Development - The World Bank (Banco

Internacional para Reconstrução e Desenvolvimento - Banco Mundial)

BIS: Bank for International Settlements (Banco de Compensações Internacionais)

BM\&F: Bolsa de Mercadorias e de Futuros

BOVESPA: Bolsa de Valores do Estado de São Paulo

CA: Créditos anormais

CAMELS: Capital, assets, management, earnings, liquidity and sensibility (capital, ativos, capacidade gerencial, resultados, liquidez e sensibilidade)

CAPM: Capital asset pricing model

CAR: Risk based capital (capital baseado no risco)

CDI: Certificado de depósito interbancário

CEMLA: Centro de Estudos Monetários Latino-Americano

CMN: Conselho Monetário Nacional

CV: Coeficiente de variação

CVM: Comissão de Valores Mobiliários

COSIF: Plano Contábil das Instituições do Sistema Financeiro Nacional

DBAC: Deutsche Bank Alarm Clock

DI: Depósito interfinanceiro

DT: Depósito total

DVA: Demonstração do Valor Adicionado

EMBI: Emerging Market Bond Index

EMRI: Emerging Markets Risk Indicator

EUA: Estados Unidos da América

FED: Federal Reserve Bank (Banco Central dos EUA)

FGC: Fundo Garantidor de Crédito

FSI: Financial soundness indicators

GS: Goldman Sachs

H\&L: Hosmer e Lemeshow

IAM: Índice de avaliação do modelo

IASB: International Accounting Standard Board (Conselho de Padrões Internacionais de Contabilidade)

IGP-M: Índice geral de preços - mercado

IMF: International Monetary Fund (Fundo Monetário Internacional - FMI)

IRATPIB: Indicador de mensuração da variação do ativo total em relação ao produto interno bruto

IRCRE: Indicador de mensuração do impacto da variação dos créditos anormais sobre o patrimônio líquido 
IRFX: Indicador de mensuração do impacto da variação na taxa de câmbio sobre o patrimônio líquido

IRLIQ: Indicador de mensuração do impacto da variação nos depósitos totais sobre os ativos líquidos

IRS: Índice de risco sistêmico

IRTJ: Indicador de mensuração do impacto da variação na taxa de juros sobre o patrimônio líquido

MPI: Macroprudential indicators

NAFTA: North American Free Trade Agreement

NOP: Net open position (posição líquida)

OC: Operações de crédito

OECD: Organization for Economic Co-operation and Development

PIB: Produto interno bruto

PL: Patrimônio líquido

PROER: Programa de Estímulo à Reestruturação e ao Fortalecimento do Sistema Financeiro Nacional

ROE: Return on equity (retorno sobre o patrimônio líquido)

RSL: Resultado líquido do exercício

SDR: Special drawing rights (depósitos especiais de saque)

SELIC: Sistema Especial de Liquidação e Custódia

UFIRS: Uniform Financial Institutions Rating System

VaR: Value at risk (Valor em risco)

VExpCRE: Valor contábil exposto ao risco de crédito

VExpFX: Valor contábil exposto ao risco de variação na taxa de câmbio

VExpTJ: Valor contábil exposto ao risco de variação na taxa de juros 


\section{LISTA DE TABELAS}

Tabela 1 - Custo fiscal de crises financeiras 12

Tabela 2 - Percentual de países com requerimento de capital baseado em risco 33

Tabela 3 - Exemplo numérico da perda esperada e não-esperada 39

Tabela 4: Valores da base monetária e dos meios de pagamento - 30.06.2005 53

Tabela 5 - A receita inflacionária dos bancos 75

Tabela 6 - Estrutura do sistema financeiro em 31.12.1996. 79

Tabela 7 - Fusões e incorporações, fechamentos e intervenções do Estado em instituição $\begin{array}{lr}\text { financeira } & 80\end{array}$

Tabela 8 - Países selecionados e datas das crises $\quad 92$

Tabela 9 - Classificação dos resultados da aplicação dos modelos $\quad 117$

Tabela 10 - Correlação de Pearson - coeficientes de variação 123

Tabela 11 - Correlação de Pearson - médias 123

Tabela 12 - Correlação de Pearson - desvios-padrão 123

Tabela 13 - Resultados da análise fatorial $\quad 126$

Tabela 14 - Teste da hipótese de coeficientes nulos - coeficientes de variação 128

Tabela 15 - Resumo do modelo - coeficientes de variação 128

Tabela 16 - Teste de Hosmer e Lemeshow - coeficientes de variação 129

Tabela 17 - Tabela de classificação - coeficientes de variação 129

Tabela 18 - Indicadores na equação - coeficientes de variação 129

Tabela 19 - Significância dos indicadores fora da equação- coeficientes de variação 130

Tabela 20 - Significância dos indicadores - oito coeficientes de variação 131

Tabela 21 - Resumo dos testes de validação do modelo - CROE e CIRTJ 131

Tabela 22 - Significância dos indicadores - CROE e CIRTJ 132

Tabela 23 - Significância dos indicadores contábeis 132

Tabela 24 - Resumo dos testes de validação do modelo - indicadores representativos das médias 134

Tabela 25 - Indicadores na equação - médias $\quad 135$

Tabela 26 - Significância dos indicadores fora da equação-médias 135

Tabela 27 - Comparação dos resultados dos pares de indicadores significativos - médias 136

Tabela 28 - Resumo dos testes de validação dos modelos - médias 137

Tabela 29 - Resumo dos testes de validação do modelo - indicadores representativos dos desvios-padrão

Tabela 30 - Indicadores na equação - desvios-padrão 139

Tabela 31 - Significância dos indicadores fora da equação- desvios-padrão 140

Tabela 32 - Comparação dos resultados dos pares de indicadores significativos - desviospadrão 141

Tabela 33 - Resumo dos testes de validação dos modelos - desvios-padrão 141

Tabela 34 - Resultados dos indicadores testados individualmente $\quad 143$

Tabela 35 - Teste de maximização das equações $\quad 150$

Tabela 36 - Exemplo de aplicação da equação 5

Tabela 37 - Classificação dos países 155 


\section{LISTA DE GRÁFICOS}

Gráfico 1 - Evolução dos índices de risco sistêmico no Brasil - mar/95 a dez/00 161

Gráfico 2 - Evolução dos índices de risco sistêmico no Brasil - dez/00 a set/05 162

Gráfico 3 - Evolução dos índices de risco sistêmico na Argentina - mar/95 a jun/05 163

Gráfico 4 - Evolução dos índices de risco sistêmico no México - set/95 a set/05 164

Gráfico 5 - Evolução dos índices de risco sistêmico na Rússia - set/95 a dez/04 165

Gráfico 6 - Evolução dos índices de risco sistêmico na Islândia - dez/93 a dez/01 166

Gráfico 7 - Evolução dos índices de risco sistêmico na Tailândia - jun/96 a dez/04 167

Gráfico 8 - Evolução dos índices de risco sistêmico na Suécia - dez/90 a dez/00 168

Gráfico 9 - Evolução dos índices de risco sistêmico no Reino Unido - dez/90 a dez/01 169

Gráfico 10 - Evolução dos índices de risco sistêmico na Austrália - dez/89 a dez/01 170

Gráfico 11 - Evolução dos índices de risco sistêmico nos Estados Unidos - dez/89 a $\mathrm{dez} / 01$ 


\section{LISTA DE FIGURAS}

Figura 1 - Diferenças entre perda esperada, não-esperada e excepcional 40

Figura 2 - Componentes da análise macroprudencial 52

$\begin{array}{ll}\text { Figura } 3 \text { - Desenho da pesquisa } & 90\end{array}$

Figura 4 - Curva da regressão logística 108 


\section{INTRODUÇÃO}

\subsection{Contextualização}

O sistema financeiro tem sido objeto de estudo há muito tempo. As pesquisas integram as mais variadas áreas das ciências e abordam desde aspectos estruturais, como a organização e o funcionamento, até conjunturais, como o comportamento e as inovações.

Contudo, apenas nos últimos vinte anos, a atenção voltou-se para a mensuração de riscos em instituições responsáveis pela intermediação financeira. $\mathrm{O}$ marco foi a publicação do Acordo de Capital da Basiléia ${ }^{1}$ (BCBS, 1988), que estabeleceu a aferição do valor em risco com base na relação entre os ativos e o patrimônio líquido, modificando a forma vigente que utilizava o endividamento, calculado pela razão entre o passivo e o patrimônio líquido.

A mudança no conceito induziu os estudos para os riscos inerentes às atividades cotidianas das instituições financeiras, destacando-se aqueles relacionados aos riscos de crédito, taxa de juros, câmbio, liquidez e, mais recentemente, risco operacional. O desafio passou a ser a obtenção de melhores formas de controle e de mensuração de riscos, com vistas à assunção de posições e à geração de lucros, sem incorrer na possibilidade de insolvência.

Em termos sistêmicos, as crises financeiras ocorridas em países da América Latina, como na Venezuela, em 1994, no México, em 1995, em países do Sudeste Asiático, em 1997, e na Rússia, em 1998, alteraram o entendimento sobre as causas que levam economias a situações de ruptura em seus sistemas financeiro e econômico.

Os estudos demonstraram que essas crises foram originadas por fraquezas nos setores financeiro e empresarial, combinadas com vulnerabilidades econômicas (LINDGREN et al., 1999; CAPRIO et al., 1998). A constatação invalidou a premissa de que as situações de estresse e crise eram unicamente motivadas pela ausência de fundamentos econômicos fortes (DIAMOND; DYBVIG, 1983).

1. Tradução de "Basel Capital Accord". 
Simultaneamente, o crescente número de operações financeiras e a maior interdependência dos mercados fizeram com que o sistema financeiro internacional assumisse a função de principal veículo de propagação de riscos à estabilidade econômica de países.

Independentemente do estágio de desenvolvimento e da solidez dos fundamentos econômicos, todos os países ligados ao sistema financeiro internacional tornaram-se suscetíveis às fragilidades verificadas em outros sistemas, proporcionalmente à intensidade do problema e ao nível de conectividade.

Considerando que a sensibilidade das instituições responsáveis pela intermediação de recursos financeiros é elevada, em face da própria atividade operacional, as alterações macroeconômicas são prontamente percebidas e assimiladas por meio de mudanças nas posições dos agentes no mercado.

Como as informações disponíveis produzem expectativas homogêneas nos participantes, existe significativa probabilidade de as instituições adotarem posições similares, com mesma direção e intensidade, concentrando a exposição em determinados riscos.

Cônscios desses aspectos e motivados pela elevada freqüência de situações de instabilidade e crise no setor bancário, que abalaram 133 dos 181 países membros do IMF (International Monetary Fund $)^{2}$, no período entre 1980 e 1996, segundo Lindgren, Garcia e Saal (1996, p.3), organismos internacionais, como o IMF, o BIS (Bank for International Settlements) e o BIRD (Bank for International Reconstruction and Development), mais conhecido como Banco Mundial $^{3}$, têm envidado esforços para controlar os riscos nos sistemas financeiros.

Recomendações sobre regras prudenciais, de implementação quase compulsória às instituições financeiras que almejam a inserção no mercado internacional, referentes à manutenção de capital mínimo compatível com o grau de risco das operações, aos controles internos e aos limites operacionais buscam coibir exposições acima de padrões que possam significar perigo à continuidade das instituições e dos mercados.

2. Em português é chamado Fundo Monetário Internacional (FMI).

3. Tradução de "The World Bank". 
Nesse contexto de riscos e controles crescentes, o sistema financeiro internacional tenta cumprir seus objetivos econômicos e sociais sem provocar desequilíbrios que impliquem em situações indesejáveis e de difícil gerenciamento como as crises financeiras.

\section{$1.2 \quad$ Justificativa e importância}

É notória a importância de estudos para evidenciar fragilidades e prever falências, tanto em empresas não financeiras, como os de Altman (1968), Kanitz (1974), Kassai (2002) e Mário (2002), quanto em instituições financeiras, realizados por Meyer e Pifer (1970), Martin (1977), Santomero e Vinso (1977), Capelletto (1995), Matias (1999), Janot (1999), Albuquerque (2000) e Oliveira e Barroso (2000).

No entanto, a dimensão das conseqüências do risco sistêmico é muito mais preocupante. A quebra isolada de uma instituição não pode ser comparada com o desmantelamento de todo o sistema financeiro.

O papel relevante e central desempenhado no crescimento e desenvolvimento econômico de qualquer país, na proporção da responsabilidade assumida pela intermediação de recursos entre os diversos agentes econômicos, faz com que a manutenção do funcionamento normal do sistema financeiro seja objeto de preocupação tanto de autoridades nacionais (bancos centrais e órgãos de supervisão) como internacionais (BIS e IMF).

A ocorrência de crises financeiras provoca desequilíbrios em toda a economia. Os efeitos de choques como a perda de reservas internacionais, a elevação das taxas de juros e a desvalorização do câmbio afetam sobremaneira, na esfera internacional, o acesso às linhas de financiamento externas, o fluxo de capitais e o comércio, e, no cenário interno, o nível de produção e emprego.

Em termos de valores, Honohan e Klingebiel (2002), com base em uma amostra de 40 países emergentes e desenvolvidos, no período entre 1975 e 2000, concluíram que o custo fiscal médio de crises no sistema financeiro equivale aproximadamente a $13 \%$ do PIB (produto interno bruto) dos países que sofreram crises. A situação é ainda pior para os países 
emergentes, onde os custos têm sido proporcionalmente superiores aos observados em países desenvolvidos.

A Tabela 1 permite avaliar a representatividade dos custos fiscais estimados de crises financeiras em diversos países emergentes e desenvolvidos.

Tabela 1 - Custo fiscal de crises financeiras

\begin{tabular}{|l|c|c||l|c|c|}
\hline País & Período & Custo / PIB (\%) & País & Período & Custo / PIB (\%) \\
\hline Argentina (I) & $1980-82$ & 55,1 & Indonésia (I) & $1992-94$ & 3,8 \\
\hline Argentina (II) & 1995 & 0,5 & Indonésia (II) & $1997-01$ & 50,0 \\
\hline Austrália & $1989-92$ & 1,9 & Japão & $1992-01$ & 20,0 \\
\hline Brasil & $1994-96$ & 13,2 & Malásia (I) & $1985-88$ & 4,7 \\
\hline Bulgaria & $1996-97$ & 13,0 & Malásia (II) & $1997-01$ & 16,4 \\
\hline Chile & $1981-83$ & 41,2 & México & $1994-01$ & 19,3 \\
\hline Colômbia & $1982-87$ & 5,0 & Nova Zelândia & $1987-90$ & 1,0 \\
\hline Coréia do Sul & $1997-01$ & 26,5 & Noruega & $1987-93$ & 8,0 \\
\hline Costa do Marfim & $1988-91$ & 25,0 & Paraguai & $1995-01$ & 5,1 \\
\hline Eslovênia & $1992-94$ & 14,6 & Polônia & $1992-95$ & 3,5 \\
\hline Espanha & $1977-85$ & 5,6 & Senegal & $1988-91$ & 9,6 \\
\hline Estados Unidos & $1981-91$ & 3,2 & Sri Lanka & $1989-93$ & 5,0 \\
\hline Equador & $1996-01$ & 13,0 & Suécia & $1991-94$ & 4,0 \\
\hline Egito & $1991-95$ & 0,5 & Tailândia (I) & $1983-87$ & 5,6 \\
\hline Filipinas (I) & $1983-87$ & 13,2 & Tailândia (II) & $1997-01$ & 32,8 \\
\hline Filipinas (II) & $1998-01$ & 0,5 & Rep. Tcheca & $1989-91$ & 12,0 \\
\hline Finlândia & $1991-94$ & 11,0 & Turquia (I) & $1982-85$ & 2,5 \\
\hline França & $1994-95$ & 0,7 & Turquia (II) & 1994 & 1,1 \\
\hline Gana & $1982-89$ & 3,0 & Uruguai & $1981-84$ & 31,2 \\
\hline Hungria & $1991-95$ & 10,0 & Venezuela & $1994-97$ & 22,0 \\
\hline
\end{tabular}

FONTE: HONOHAN; KLINGEBIEL, 2002, p. 25.

Todavia, as recomendações de organismos internacionais, especialmente do BIS, ao tratar de tópicos como os requisitos para uma supervisão bancária eficaz (BCBS, 1997a), ainda estão centradas no comportamento das instituições financeiras. Na opinião de Lehar (2003, p.3), “[...] a idéia por trás da estrutura regulamentar atual é que há pouco risco para o sistema bancário na medida em que o risco dos bancos individuais seja pequeno."

Infelizmente, a garantia de sistemas financeiros seguros e protegidos de oscilações está além da situação econômico-financeira individual satisfatória das instituições.

As crises observadas nos países do Sudeste Asiático e da América Latina demonstraram que os movimentos conjuntos dos agentes econômicos, tais como as "corridas bancárias", para

4. Tradução de "The idea behind the current regulatory framework is that there is little risk for the banking system as a whole as long as the default risk of individual banks is low." 
realização de saques em depósitos pelas pessoas físicas e jurídicas não-financeiras, e a compra de moedas estrangeiras pelas instituições financeiras, para proteção à iminente desvalorização da moeda local, foram os responsáveis pela generalização das crises.

Esses movimentos conjuntos afetaram todo o sistema e provocaram insolvências e prejuízos a instituições e pessoas físicas indistintamente, independentemente da situação econômicofinanceira individual. Sobrepesa ainda o relacionamento financeiro existente entre os países vizinhos, o qual foi determinante para espraiar a crise em toda a região pelo "efeito contágio".

Caso houvesse o conhecimento prévio das causas geradoras dos movimentos e tivessem sido adotadas ações tempestivas pelos órgãos responsáveis para contrabalançar as posições, reequilibrar o sistema e garantir a credibilidade, as crises poderiam ter sido evitadas ou arrefecidas.

Segundo Lindgren et al. (1999, p.29), a Malásia e as Filipinas não sofreram todo o impacto da crise porque adotaram medidas preventivas um ano antes da crise, iniciada em julho de 1997, que reduziram os prejuízos comparativamente aos observados na Coréia do Sul, Indonésia e Tailândia.

Dado que a associação de exposições a diferentes tipos de riscos possa configurar situações não observadas na análise do risco isoladamente, estudos com enfoque integrado têm ganho importância. O acompanhamento dos riscos conjuntamente permite a identificação do momento em que patamares perigosos para a continuidade de todo o sistema são atingidos.

Adicionalmente, a presumida influência recíproca entre a estabilidade econômica e a saúde do sistema financeiro, cujos efeitos podem ser capturados nas variáveis econômicas do país e contábeis do sistema bancário, aponta para o desenvolvimento de estudos que contemplem ambos os grupos de variáveis.

Não obstante, a literatura sobre risco sistêmico demonstra o pouco uso das variáveis contábeis, conforme pode ser observado no referencial teórico dos trabalhos elaborados por De Bandt e Hartmann (2000) e Kaminsky, Lizondo e Reinhart (1998). 
Como não há justificativa clara para a ausência de informações contábeis relevantes nas pesquisas sobre risco sistêmico e crise financeira, dado que sempre mostram, em algum momento, a real situação econômico-financeira, faz-se mister testar as variáveis contábeis, analisar os resultados e apresentar as devidas conclusões.

A concentração no uso de variáveis econômicas nos estudos, relativas às políticas monetária e cambial, tem originado explicações para as crises exclusivamente sob o fulcro de aspectos econômicos.

Outra justificativa importante para a construção e a acumulação de conhecimentos sobre riscos é a contínua exposição dos mercados emergentes, inclusive o Brasil, à crise sistêmica.

A capacidade de mensurar a probabilidade de crises no sistema financeiro é imprescindível à correta utilização de recursos humanos, materiais e financeiros. Tanto o gasto de recursos, quando desnecessário, como a falta deles, em momentos cruciais, representa prejuízos suportados pela sociedade.

Ante o exposto, a identificação de variáveis e a aferição do grau de relevância no processo de ocorrência do risco sistêmico podem subsidiar a decisão de intervenção do Estado na estabilização e diminuição de riscos no sistema bancário. O prévio conhecimento de qualquer sinal indicativo da perda de continuidade do sistema, expresso no agravamento simultâneo do nível de risco no conjunto de instituições financeiras, é de suma importância às autoridades responsáveis pelos mercados.

Entre os principais beneficiários institucionais encontram-se, na esfera internacional, o IMF, o BIS, o BIRD, o BID (Banco Interamericano de Desenvolvimento), o CEMLA (Centro de Estudos Monetários Latino-Americano) e a ASBA (Associação de Supervisores Bancários da América Latina) e, no âmbito nacional, os órgãos responsáveis pela condução das políticas monetária, fiscal e de crédito, supervisão do sistema financeiro, gestão do mercado de capitais e arrecadação de tributos.

Além desses, a utilização do instrumento de forma preventiva pelas autoridades competentes estende o benefício a todos os participantes do mercado e à sociedade em geral, haja vista as conseqüências de uma crise generalizada. 


\subsection{Problema e hipótese de pesquisa}

Conforme apresentado, a ausência de variáveis contábeis do sistema bancário em pesquisas sobre crises financeiras, mesmo considerando a provável correlação com a situação econômica, abre espaços para os seguintes questionamentos que podem ser respondidos pelo estudo empírico:

a) As variáveis contábeis e econômico-contábeis (de riscos) são capazes de mensurar o risco bancário sistêmico e conseqüentemente sinalizar a probabilidade de ocorrência de crises no setor bancário?

b) Em caso afirmativo, quais são as variáveis mais relevantes?

Para respondê-las, os seguintes objetivos gerais e específicos são estabelecidos.

\section{$1.4 \quad$ Objetivos}

\subsubsection{Objetivo geral}

- Demonstrar que os indicadores contábeis e de riscos apresentam conteúdo informacional para mensurar o nível de risco sistêmico no setor bancário.

\subsubsection{Objetivos específicos}

- Identificar os indicadores contábeis e de riscos mais associados com a ocorrência de crise bancária sistêmica.

- Verificar a associação dos riscos de crédito, de taxa de juros, de câmbio e liquidez com a crise bancária sistêmica.

- Avaliar os resultados e validar a regra de classificação das situações de suscetibilidade e não-suscetibilidade à crise bancária sistêmica.

- Analisar as características comuns evidenciadas pela contabilidade no período que antecede a crise bancária sistêmica. 


\section{$1.5 \quad$ Limitação}

O método indutivo proposto para o estudo tem como limitação principal a quantidade e a confiabilidade dos dados disponíveis. Como os resultados dos testes estatísticos são dependentes dos dados que compõem a amostra, a falta de informações sobre determinados países e variáveis representa uma grave limitação à pesquisa.

Por conseguinte, os resultados tendem a estar condicionados às variáveis dos países integrantes da amostra. Mesmo com a utilização de países e períodos variados, a aplicação indiscriminada das regras de classificação, especialmente para outros períodos fora da amostra, somente pode ser feita com ressalvas.

Igualmente, a não utilização de variáveis relacionadas com outros fatores causadores de crises financeiras como ataques terroristas ${ }^{5}$, guerras, eleições, crises políticas, liberalização econômica, regulamentação, etc., restringe a identificação das causas determinantes das crises ao grupo de variáveis testadas.

Adicionalmente, existe a dificuldade provocada pela existência de critérios contábeis diferenciados nos países da amostra, que podem resultar em informações heterogêneas. Para evitar o problema, na medida do possível, houve a escolha de variáveis menos sujeitas à discricionariedade contábil do país e amplamente utilizadas nos processos de avaliação implementados pelos organismos internacionais.

Assim, a pesquisa está limitada a um conjunto de variáveis contábeis e econômicas de países que contêm dados disponíveis a partir de 1990, sendo que a generalização da aplicação dos resultados depende da existência de características comuns no sistema bancário do país objeto de análise.

\subsection{Estrutura do trabalho}

Com vistas a atingir os objetivos estabelecidos, o estudo está organizado em seis capítulos.

5. O ataque ao World Trade Center em 11/09/2001, nos Estados Unidos, abalou os mercados financeiros e de capitais. 
Este Capítulo introdutório apresenta a contextualização, a justificativa, a importância, o problema e a hipótese de pesquisa, os objetivos e a limitação do estudo sobre a mensuração do risco sistêmico no setor bancário com utilização de variáveis contábeis e de riscos.

O Capítulo 2 contém o referencial teórico, no qual são apresentados os conceitos e as definições dos tipos de riscos inerentes ao sistema financeiro, as variáveis contábeis e econômicas usadas na avaliação de riscos, e a função do patrimônio líquido na cobertura dos riscos. Em adição, é feita uma síntese dos principais estudos sobre crises monetárias e bancárias, bem como um relato das crises mais severas que afetaram os sistemas financeiros após 1990.

O Capítulo 3 é referente à metodologia. Compreende o detalhamento da composição da amostra e dos indicadores utilizados, além da escolha dos métodos estatísticos, com os respectivos critérios de validação e avaliação.

O Capítulo 4 expressa a análise dos resultados da aplicação das técnicas estatísticas. Evidencia a validação quantitativa dos modelos e dos indicadores e apresenta a interpretação qualitativa dos aspectos contábeis e econômicos considerados mais relevantes.

O Capítulo 5 tem por objetivo avaliar as equações validadas, compostas por indicadores estatisticamente significativos, com vistas a identificar aquelas que maximizam a classificação dos países em suscetíveis e não-suscetíveis à crise bancária, de acordo com a prioridade estabelecida para o tipo de erro. Seqüencialmente, apresentam-se os resultados obtidos pela aplicação dessas equações em países da amostra, tanto nos períodos utilizados para obtenção das fórmulas quanto em outros, demonstrando a eficácia dos índices de risco sistêmico (IRS) na mensuração do risco no setor bancário.

O Capítulo 6 resume as contribuições da pesquisa. Evidencia o cumprimento dos objetivos estabelecidos, com exposição das características comuns extraídas da contabilidade nos momentos que antecedem as crises e discrimina os países suscetíveis dos não-suscetíveis, apresenta as vantagens e os benefícios que podem ser obtidos pela utilização dos índices de risco sistêmico, e, finalmente, contêm sugestões para novas pesquisas sobre o risco sistêmico sob o enfoque contábil. 
Ao final, são relacionadas as referências bibliográficas e apresentados os anexos e os apêndices importantes à compreensão da pesquisa. 


\section{REFERENCIAL TEÓRICO}

A revisão da literatura visa apresentar definições, conceitos e estudos que proporcionam entendimento sobre o objeto da pesquisa e que sirvam de referência à formulação da metodologia, especialmente no tocante à identificação das variáveis econômicas e contábeis empregadas na avaliação de risco sistêmico e previsão de crises financeiras, além de contribuir para a escolha da técnica estatística mais apropriada.

\section{$2.1 \quad$ Riscos}

\subsubsection{Conceitos e definições}

O risco é uma variável determinante à evolução humana, pois a sua ausência implica a certeza de resultados e a restrição à construção de conhecimentos. Sem o risco, a esperança de obter algo melhor é tolhida.

Não obstante o antigo conceito, a concepção atual de risco tem origem nos números, que permitiram quantificar o valor incerto, até então abstrato, resultante de determinada ação. A avaliação da incerteza representou o domínio do risco e definiu a fronteira entre os tempos moderno e passado, pois, segundo Bernstein (1997, p.1), inseriu a “[...] noção de que o futuro é mais do que um capricho dos deuses e de que homens e mulheres não são passíveis ante a natureza".

Contudo, o risco não pode ser confundido com a incerteza. Enquanto o risco está dimensionado em probabilidades, calculadas com base em dados históricos ou em parâmetros futuros, a incerteza não tem amparo na racionalidade e está restrita à percepção discricionária do agente, produzindo decisões alicerçadas na experiência e sensibilidade pessoal.

Uma definição simples e direta da relação entre os conceitos de risco e incerteza, apresentada por Solomon e Pringle (1981 apud SECURATO, 1996, p. 27), é que o "[...] risco é o grau de incerteza a respeito de um evento." 
Na construção da relação entre o risco e o surgimento do capitalismo, idealizada por Bernstein (1997, p.21), emerge a imprescindibilidade do conhecimento contábil, que proporcionou o registro dos fatos e a visão gerencial dos negócios, capacitando a previsão de resultados, condicionados à assunção de riscos proporcionais à compensação esperada.

Em finanças, o risco é a probabilidade de não obter o retorno esperado sobre o investimento realizado. O risco é definido como a própria variância do retorno. Quanto maior a amplitude desse desvio, maior será o resultado exigido para compensar o risco assumido.

O desvio do retorno apresenta dois fatores como causas. Um referente às características intrínsecas da operação ou da contraparte, como a garantia prestada ou a capacidade de pagamento do devedor, chamado de risco idiossincrático, não-sistemático ou diversificável. E outro, não-controlável, relacionado ao ambiente ou ao sistema, conhecido como risco sistemático ou não-diversificável, independente das características específicas inerentes a cada um dos ativos (MARTINS; ASSAF NETO, 1986, p.467).

A respeito, Ross, Westerfield e Jaffe (1995, p.233) definem: “Um risco sistemático é qualquer risco que afeta um grande número de ativos, e cada um deles com maior ou menor intensidade.", e "Um risco não-sistemático é um risco que afeta especificamente um único ativo ou um pequeno grupo de ativos." A imprecisão na quantidade e o acréscimo na gradação da intensidade ampliam a abrangência e a caracterização do risco sistemático.

Sobre o assunto, não é possível omitir a contribuição de Markowitz para a teoria de finanças. Ao introduzir a noção de risco e de diversificação na formação de carteira de ações, ele revolucionou a gestão de riscos. A inserção do conceito de diversificação na estratégia de investimentos proporcionou a otimização da carteira, ao buscar a diminuição dos efeitos dos riscos idiossincráticos inerentes a cada um dos ativos.

O conceito de carteira "eficiente" apresentado por Markowitz (1952, p.87) consiste em aplicar em ativos que ofereçam conjuntamente o máximo retorno possível à determinada volatilidade aceita pelo investidor, que pode ser conservador ou agressivo, de acordo com a propensão a assumir riscos. 
Até esse conceito, a premissa era investir em ativos ao melhor preço para obter o maior retorno, sem considerar os riscos envolvidos e a relação entre o comportamento dos ativos componentes de uma carteira. Após Markowitz, a importância do risco foi igualada ao retorno, sendo que o objetivo principal passou a ser a minimização da variância para um mesmo retorno. A genialidade do modelo foi provar que a volatilidade no retorno de uma carteira de ativos pode ser minimizada pela aplicação em ativos que sejam não perfeitamente correlacionados entre si.

Para Bernstein (1997, p.253), a visão anterior dos investidores, de vencer o mercado, representava uma receita quase certa para o fracasso. Ao diversificar, no lugar de concentrar o investimento em um único ativo, o investidor pelo menos maximiza as probabilidades de sobrevivência.

No mercado internacional, os países representam oportunidades de investimentos com riscos e retornos distintos. As diferenças residem na percepção da qualidade dos fundamentos econômicos e da solidez do sistema financeiro de cada país. Diante disso, o investidor internacional tende a diversificar a sua carteira, escolhendo aqueles países localizados na linha da carteira eficiente, que oferecem ao conjunto o melhor retorno ao menor nível de risco. Essa busca representa a tentativa de eliminar o risco idiossincrático de cada país da carteira de investimentos.

Considerando que o nível de risco sistêmico interno ao país corresponde ao risco idiossincrático no contexto internacional, o conhecimento das causas e do nível em que se encontra permite a adoção de estratégias que visem reduzir o risco e melhorar a atratividade do país para os investidores.

\subsubsection{Riscos inerentes ao sistema financeiro}

O sistema financeiro tem especificidades operacionais que o diferenciam dos demais setores. A função de intermediar recursos entre os agentes superavitários, denominados investidores, e os agentes deficitários, tomadores de recursos, coloca os intermediadores financeiros no centro do fluxo econômico.

As atividades de transformação da liquidez, dos prazos e da magnitude dos objetos 
transacionados são permeadas por riscos que exigem controles adequados e capacitação gerencial. Atualmente, os principais riscos encontrados nas operações realizadas no sistema financeiro são os riscos de crédito, de mercado e de liquidez.

\subsubsection{Risco de crédito}

A definição de risco de crédito é a probabilidade de o tomador de recursos, também chamado de contraparte, não pagar ou honrar as obrigações assumidas, tanto no que tange ao principal quanto ao serviço da dívida.

Bessis $(1998$, p.81) acrescenta à definição a deterioração da qualidade do crédito. Para o autor, "Risco de crédito é definido pela perda no evento de não pagamento do devedor, ou no evento de deterioração da qualidade do crédito do devedor." ${ }^{\prime 6}$ Sob esse entendimento, a elevação do risco é resultante não somente pela falta do pagamento de uma obrigação, mas também pela redução da capacidade de pagamento do devedor, podendo ser configurada pela assunção de dívidas acima da capacidade de endividamento, pedidos de concordata e falência ou mesmo pela configuração da insolvência.

O risco de crédito está presente nas operações em que existe um compromisso de um agente para com outro, podendo advir tanto dos tradicionais empréstimos e financiamentos, como de operações compromissadas, transações interbancárias, operações de câmbio, instrumentos derivativos e de garantias e avais prestados. O importante é que, estabelecida a obrigação de um para com outro, existe o risco de crédito.

Assim, observada a atividade característica de intermediação financeira, a gestão do risco de crédito é fundamental à manutenção da continuidade dos negócios.

O documento do Comitê da Basiléia sobre Supervisão Bancária (BCBS, 2000a, p.1), intitulado Principles for the Management of Credit Risk, relata que:

6. Tradução de "Credit risk is defined by the losses in the event of default of the borrower, or in the event of a deterioration of the borrower's credit quality." 
[...] a maior causa de problemas no setor bancário ainda tem sido diretamente relacionada com o relaxamento nas exigências para a concessão de crédito, o pobre gerenciamento do risco ou a falta de atenção a mudanças econômicas ou em outras circunstâncias que podem levar à deterioração da capacidade de pagamento das contrapartes. $^{7}$

Esse documento estabelece também dezessete princípios para a melhoria do gerenciamento do risco de crédito, os quais abordam desde a implementação de um processo adequado à análise e à concessão de crédito, incluindo a definição de responsabilidades, até a manutenção de uma apropriada gestão, avaliação e monitoramento do crédito.

Para mensurar adequadamente o risco de crédito, duas dimensões devem ser observadas. Uma de ordem quantitativa, relativa ao montante de crédito concedido, e outra qualitativa, que abrange aspectos como a situação econômico-financeira do tomador do crédito, o histórico de inadimplemento, a aplicação dada aos recursos, a moeda, o indexador e o prazo da operação, a atividade econômica predominante e as garantias recebidas (BESSIS, 1998, p. 6).

Há de se ressaltar que a gestão de crédito é muito mais do que a simples avaliação do potencial de pagamento da contraparte. O principal objetivo é maximizar a taxa de retorno ajustada ao risco das operações, mediante a manutenção da exposição ao risco de crédito em nível aceitável, tanto individual quanto para toda a carteira.

Adicionalmente, o risco de crédito deve ser administrado conjuntamente com os demais riscos, especialmente em face da complementaridade do risco de mercado. Como dois lados de uma mesma moeda, em condições normais, o aumento do risco de crédito representa a redução do risco de mercado e vice-versa. A falha nesse processo geralmente produz significativas perdas e até a descontinuidade da instituição.

\subsubsection{Risco de mercado}

O Comitê da Basiléia sobre Supervisão Bancária (BCBS, 1996, p.1) define o risco de mercado como a possibilidade de perda em posições, dentro e fora do balanço, provocada por

7. Tradução de "[...] the major cause of serious banking problems continues to be directly related to lax credit standards for borrowers and counterparties, poor portfolio risk management, or a lack of attention to changes in economic or other circumstances that can lead to a deterioration in the credit standing of a bank's counterparties." 
movimentos nos preços de mercado, podendo ser causado pela alteração nas taxas de juros, na taxa de câmbio e no preço de ações e "commodities".

Observada a equação fundamental do patrimônio (IUDICÍBUS, 1998, p. 31; HENDRIKSEN; VAN BREDA, 1999, p.466):

Patrimônio líquido $=$ Ativo - Passivo

A exposição do ativo e do passivo a riscos de mercado pode ser assim representada contabilmente:

Ativo Total $=$ Ativo TJ + Ativos FX + Ativos PREÇO

Passivo Total $=$ Passivo TJ + Passivo FX + Passivo PREÇO

Por dedução, sob o enfoque do risco de mercado, o patrimônio líquido (PL) equivale ao somatório das posições líquidas em taxa de juros, taxa de câmbio e preços, conforme a seguinte equação:

PL = Posição líquida TJ + Posição líquida FX + Posição líquida PREÇO

onde $T J$ é o risco de variação na taxa de juros, $F X$ é o risco de variação na taxa de câmbio e $P R E C ̧ O$ é o risco de variação nos preços de ações e commodities.

Em termos de risco, faz-se importante ressaltar que apenas a variação na taxa de juros, na taxa de câmbio e nos preços constitui o risco que deve ser suportado pelo patrimônio líquido. Assim, o patrimônio líquido precisa ser maior do que o somatório dos valores resultantes nas variações das taxas e dos preços, atendendo a seguinte relação:

Patrimônio líquido > (Variação em TJ * Posição líquida em TJ) + (Variação em FX * Posição líquida em FX) + (Variação em PREÇO * Posição líquida em PREÇO) 
Como a definição contempla a subdivisão do risco de mercado em três tipos, de acordo com a variável de referência, denominados de risco de taxa de juros, risco de câmbio e risco de preços, uma breve explanação é feita, a seguir, sobre cada um.

\subsection{Risco de taxa de juros}

O risco de taxa de juros é a probabilidade de perda em ativos, passivos e itens extrapatrimoniais decorrente de alteração na taxa de juros que indexa as operações. Segundo Crouhy, Galai e Mark (2004, p.159), “A forma mais simples de risco de taxa de juros é o risco de que o valor de um título de renda fixa cairá como resultado de uma mudança nas taxas de juros de mercado."

Para o Comitê da Basiléia sobre Supervisão Bancária (BCBS, 2004, p.5), "[...] risco de taxa de juros é a exposição da situação financeira do banco a movimentos adversos na taxa de juros." ${ }^{\prime} \mathrm{O}$ ponto comum das definições é a possibilidade de uma mudança significar perda para o possuidor do item objeto exposto à taxa de juros.

Identicamente ao risco de crédito, o risco de taxa de juros é inerente à atividade de intermediação financeira e está contido em todas as operações referenciadas em taxa de juros. A exposição ao risco de taxa de juros é calculada sobre todas as posições ativas, passivas e em derivativos, remuneradas pelas taxas de juros pré-fixadas ou pós-fixadas, ou cujo valor sofra alterações quando há variação na taxa de juros.

A mensuração do risco depende da volatilidade do comportamento da taxa de juros e das correlações existentes entre os itens referenciados. Operações realizadas em mercados com maior variância na taxa de juros implicam em maior risco às posições assumidas pelas instituições participantes, exigindo maior volume de patrimônio líquido para cobrir possíveis perdas não esperadas.

8. Tradução de "Interest rate risk is the exposure of a bank's financial condition to adverse movements in interest rates." 


\subsection{Risco de câmbio}

Semelhante ao risco de taxa de juros, o risco de câmbio é a probabilidade de perda em virtude de variação adversa na taxa de câmbio. Ao assumir posições líquidas ativas ou passivas, também chamadas de compradas ou vendidas, respectivamente, a instituição fica exposta à variação cambial.

De acordo com Greuning e Bratanovic (1999, p. 211), o risco de câmbio é "[...] um risco de volatilidade devido ao descasamento das posições, e pode causar perdas resultantes de movimentos adversos durante o período em que a posição estava aberta em moeda estrangeira, no balanço ou fora dele, no mercado à vista ou futuro."9

A exposição ao risco de câmbio é calculada sobre todas as posições ativas, passivas e em derivativos constituídas ou referenciadas em moeda estrangeira. Quando ocorre a variação na moeda estrangeira em relação à moeda nacional, receitas ou despesas são geradas na proporção da variação e na posição líquida.

A principal diferença entre o risco de taxa de juros e o de câmbio está no caráter exógeno dessa última. Enquanto a taxa de juros é administrada internamente e consiste em uma decisão até certo ponto autônoma da autoridade monetária, a taxa de câmbio é determinada por fatores externos, não-controláveis pelos países.

As tentativas de controle da taxa de câmbio experimentadas em diversos países, pela adoção de regimes de câmbio fixo ou administrado, tiveram conseqüências indesejáveis de elevado custo, pagas pela redução das reservas internacionais ou pelo aumento da taxa de juros.

\subsection{Risco de preços}

O risco de preços é a probabilidade de perda associada à alteração nos preços de mercado de ativos, passivos e itens extra-patrimoniais. A diferença em relação aos riscos de taxa de juros e câmbio está na inexistência de um indexador de referência explícito para remunerar o item objeto. O valor é dado pelo preço de mercado, sem vinculação direta com as demais variáveis.

9. Tradução de "It is a risk of volatility due to a mismatch, and may cause a bank to experience losses as a result of adverse exchange rate movements during a period in which it has an open on - or off-balance-sheet position, either spot or forward, in an individual foreign currency." 
Os itens expostos ao risco de preços, no sistema financeiro, estão restritos aos valores mobiliários, classificados como títulos de renda variável, em face da dependência do retorno ao desempenho do emissor, e commodities.

\subsubsection{Risco de liquidez}

O risco de liquidez é causado pelos descasamentos de prazo, indexador, moeda e valor entre os pagamentos e os recebimentos. A diferença entre as operações passivas (depósitos) e as ativas (créditos) é a razão da periculosidade e da preocupação dos reguladores com o sistema financeiro.

Segundo o Comitê da Basiléia sobre Supervisão Bancária (BCBS, 2000b, p. 1), “[...] a importância da liquidez transcende o banco individualmente, desde que a escassez de liquidez em uma simples organização possa ter repercussões sistêmicas. Assim, o gerenciamento de liquidez está entre as atividades mais importantes conduzidas pelos bancos." 10

A falta de liquidez obriga a rápida realização de ativos, com conseqüente queda no preço. Outras instituições detentoras de ativos iguais ou semelhantes têm seus ativos também desvalorizados. A constatação desse fato pelos depositantes é suficiente para provocar saques inadvertidos e gerar a "corrida bancária".

A principal conseqüência indesejada do desequilíbrio é incapacitar a instituição ao cumprimento de suas obrigações de curto prazo. As decisões sobre as aplicações e as captações, conjugadas com o ambiente de atuação, afetam diretamente o nível de liquidez.

Para aferição da situação líquida, as diferentes posições de liquidação de seus direitos e obrigações são consideradas. Há necessidade de elaborar simulações para verificar o impacto dos diferentes cenários no fluxo de caixa, bem como realizar avaliações voltadas à identificação de mecanismos e instrumentos que permitam a obtenção dos recursos

10. Tradução de "the importance of liquidity transcends the individual bank since a liquidity shortfall at a single organisation can have systemic repercussions. The management of liquidity is therefore among the most important activities conducted at banks." 
necessários à reversão de posições que coloquem em risco a liquidez, englobando as alternativas disponíveis nos mercados financeiros e de capitais.

Isoladamente, o risco de liquidez é conseqüente de decisões que expuseram os ativos, passivos e itens extra-patrimoniais aos riscos de crédito e de mercado. Normalmente, quando o problema de liquidez é percebido, o resultado e o patrimônio líquido já sofreram o impacto.

Em termos sistêmicos, existe estreita relação entre o comportamento da liquidez da instituição e do ambiente. Tanto os fatores externos são determinantes à situação líquida das instituições, quanto à situação individual influencia a liquidez do ambiente.

\subsubsection{Risco sistêmico}

As definições de risco sistêmico no setor financeiro ou bancário encontradas na literatura são variadas e estão relacionadas aos objetivos das pesquisas. Algumas têm como essência a ocorrência de um choque capaz de produzir efeitos adversos na maior parte do sistema ou da economia.

Sob esse enfoque, Bartholomew e Whalen (1995, p.4) apresentam risco sistêmico como: “[...] um evento com efeitos em todo o sistema econômico e financeiro, e não apenas em poucas instituições."11 Nessa definição, não há menção à dependência de conexões entre os participantes, pois o choque é suficientemente abrangente e forte para atingir todos indistintamente.

Outras são baseadas no efeito da contaminação dos problemas de um agente para outros, chamado de "efeito contágio", como a do BIS (1994, p.177): “O risco que o não cumprimento das obrigações contratuais por um participante pode causar ao cumprimento das obrigações de outros pode gerar uma reação em cadeia de dificuldades financeiras maiores." ${ }^{12}$, e a de Kaufman (1995, p.47): “[...] é a probabilidade de que perdas acumuladas em um evento se propaguem ao conjunto de instituições e mercados que compõem o sistema [...]. Isto é, o risco

11. Tradução de "...refers to an event having effects on the entire banking financial, or economic system, rather than just one or a few institutions."

12. Tradução de "the risk that the failure of a participant to meet its contractual obligations may in turn cause other participants to default with a chain reaction leading to broader financial difficulties." 
de um efeito-dominó."13 Nesses casos, a premissa é a conectividade entre os participantes, principalmente via sistema de pagamentos e mercado interbancário.

Uma definição alternativa de risco sistêmico é também relacionada com o "efeito contágio", mas não diretamente, pois depende de outros fatores e de relações indiretas. O cerne da definição está na possibilidade de uma instituição importante do sistema ter problemas e fomentar incerteza a todos os demais participantes, conduzindo ao chamado "efeito manada", sob o qual decisões não justificadas pela situação econômico-financeira são tomadas. A explicação desses atos irracionais é apresentada em estudos sobre finanças comportamentais e está centrada na aversão à perda pelos participantes.

Restringindo às crises monetárias, que geralmente são concomitantes às crises bancárias sistêmicas, Eichengreen, Rose e Wyplosz (1994) definem crise como movimentos adversos significativos na taxa de juros, de câmbio e nas reservas internacionais. No mesmo contexto, Kaminsky, Lizondo e Reinhart (1998, p.15) descrevem a crise como: “[...] uma situação na qual o ataque à moeda leva à rápida depreciação do valor da moeda ou à perda nas reservas internacionais, ou à combinação das duas."14

Embora existam várias definições de crises sistêmicas, Freixas, Parigi e Rochet (1999, p.2) mencionam que a teoria ainda não conseguiu consolidar uma estrutura conceitual apropriada sobre risco sistêmico. De qualquer forma, todas mencionam a presença de eventos turbulentos suficientemente fortes e a propagação pelo "efeito contágio" como causa da instabilidade generalizada. Por vezes, as causas misturam-se não sendo possível distinguir o choque do "efeito contágio".

Em convergência com essa observação, Furfine (1999) tipifica o risco sistêmico como sendo derivado de um choque causador de problemas generalizados ao funcionamento normal de todo o conjunto, ou provocado pela disseminação dos problemas originados em uma unidade para o todo, por meio das conexões existentes.

13. Tradução de "probability that cumulative losses will accrue from an event that sets in motion a series of successive losses along a chain of institutions or markets comprising a system...That is, the risk of a chain reaction of falling interconnected dominos."

14. Tradução de "... a situation in which an attack on the currency leads to a sharp depreciation of the currency, a large decline in international reserves, or a combination of the two." 
Para o estudo, o risco sistêmico é o grau de incerteza existente no sistema resultante de alterações no nível de risco do crédito, da taxa de juros e da taxa de câmbio. A mensuração é feita pelo impacto da alteração nos riscos sobre o patrimônio líquido do sistema. Quanto maior a perda não-esperada produzida pela alteração no nível de risco, maior é o risco sistêmico.

No tocante à definição de crise bancária sistêmica, consiste em um choque capaz de estressar, no conjunto ou isoladamente, os riscos de crédito, de taxa de juros e de câmbio, na maior parte das instituições que compõem o sistema. Nessa situação, os agentes constatam que o somatório do capital das instituições é insuficiente para cobrir as perdas não-esperadas produzidas pelo choque, provocando a ruptura no funcionamento normal do sistema.

Deduz-se assim que os riscos de crédito, de taxa de juros e de câmbio tornam-se sistêmicos quando estão generalizadamente estressados. A crise, por sua vez, representa o estresse do risco sistêmico, quando todos perdem a credibilidade na continuidade do sistema.

A observação dos efeitos dos choques sobre as variáveis de natureza econômica, como taxa de juros, taxa de câmbio e reservas internacionais, e contábil, como créditos vencidos, ativos líquidos ou depósitos à vista e patrimônio líquido permite mensurar o nível de risco sistêmico.

Em relação à distinção constante na literatura entre a crise monetária e a crise bancária, considera-se irrelevante para o propósito do estudo, visto que o objetivo é mensurar o nível de risco sistêmico independentemente dos fatos geradores.

Além disso, as crises observadas em países emergentes nos anos de 1990 são marcadas tanto por problemas no sistema bancário como no balanço de pagamentos, sendo denominadas de “crises gêmeas” (KAMINSKY; REINHART, 1999). A constatação de que as crises bancárias predominantemente precedem as crises sistêmicas (GRUBEN; WELCH, 1999, p.12), corrobora a proposta de utilizar variáveis contábeis para sinalizar e mensurar o risco sistêmico.

Pelo exposto, ambas as crises são consideradas como crises sistêmicas no setor bancário e a existência de características comuns gera a perspectiva de encontrar variáveis explicativas relevantes das causas das crises contidas na amostra. 


\subsubsection{Fundamentação do Patrimônio líquido como referência à cobertura de riscos}

Formuladas as definições sobre risco sistêmico e crise bancária, depreende-se que a característica básica para existência e funcionamento de um sistema financeiro é a confiança. Os agentes superavitários e deficitários somente procuram o intermediador financeiro porque acreditam que seus interesses são seguramente atendidos.

A garantia, em termos contábeis, está expressa na diferença positiva entre os ativos e os passivos da instituição. Para Iudícibus (1981, p.148), “[...] o patrimônio líquido pode ser simplesmente definido como a diferença, em determinado momento, entre o valor do ativo e do passivo, atribuindo-se a este último a conotação restrita de dívidas e obrigações." Ou seja, quando há superioridade nos valores dos ativos em relação ao valor dos passivos, existe a percepção de que a instituição tem capacidade de honrar todas as obrigações e ainda sobram recursos para os proprietários. Nessa situação, diz-se que a instituição tem patrimônio líquido positivo e está solvente.

Cabe assim ressaltar que os critérios utilizados para mensurar os ativos e os passivos são fundamentais à determinação do valor do patrimônio líquido. Iudícibus (1981, p.149) enfoca este aspecto citando que o patrimônio líquido não representa o valor de mercado e nem um valor subjetivo da empresa para os proprietários, mas apenas a diferença do somatório dos resultados dos critérios de mensuração empregados na avaliação de ativos e passivos.

A preocupação com o valor do patrimônio líquido ganha importância no contexto do sistema financeiro, onde o maior nível de alavancagem é sinônimo de maior retorno, a exposição a riscos é constante, as instituições operam interligadas e a confiança é crucial para o funcionamento. Isso significa que a falta de capitalização adequada implica em vulnerabilidade frente ao inesperado, tornando a instituição ou o sistema frágil.

Por isso, o patrimônio líquido é o principal elemento considerado na avaliação da situação econômica das instituições. Mesmo problemas de qualidade nos ativos ou a perda de depósitos podem ser suportados, até determinado limite, quando há patrimônio líquido em nível adequado.

A capacidade do "colchão" de segurança em suportar os vários riscos e absorver as possíveis perdas provê credibilidade ao mercado. 
Não obstante, há um aspecto que pode levar à redução proporcional do capital. Paradoxalmente, a busca pela manutenção da rentabilidade dos sócios faz com que os gestores aumentem a aplicação em ativos de maior rendimento e risco, proporcionando maior exposição do patrimônio líquido a perdas.

Alternativamente, a maximização pode ocorrer pela redução do capital próprio investido ou pela substituição por passivos menos onerosos, mas isso não é facilmente exeqüível, especialmente no setor financeiro. A conseqüência desafiadora imposta aos gestores é fazer a instituição crescer, mesmo incorrendo em riscos maiores.

Nessa situação, a intervenção dos órgãos reguladores é vital à continuidade do sistema. A definição de limites operacionais às instituições é a medida prudencial requerida para evitar a exposição a riscos excessivos, assim entendidos aqueles incapazes de serem absorvidos pelos recursos próprios dos proprietários.

Consciente disso, o Comitê da Basiléia sobre Supervisão Bancária editou o Acordo de Capital da Basiléia (BCBS, 1988) e respectivos “amendments" posteriores. Esse documento foi motivado pela percepção de que a intensa concorrência entre os bancos internacionais estava induzindo algumas instituições a adotar baixos níveis de capital, em proporção ao volume de ativos, na busca de ampliação de suas parcelas de mercado. A idéia central foi oferecer condições mais eqüitativas de competição em um mercado globalizado. Para tanto, houve o estabelecimento de limites de exposição a riscos com base no capital elegível da instituição.

O montante de capital necessário para garantir o funcionamento estável das instituições, medido pelo volume e característica das operações, ficou conhecido como Limite de Basiléia. O conceito desse limite está na capacidade de absorção de perdas pelo capital sem prejudicar as atividades operacionais. Assim, as instituições foram compelidas a manter um nível mínimo de capital compatível com o grau de risco de suas operações ativas, passivas e fora do balanço.

Essa medida é um divisor de águas sob o ponto de vista da regulação prudencial, pois modifica o enfoque de risco da supervisão, migrando do lado do passivo para o ativo, em função do nível de risco gerado pelas aplicações dos recursos financeiros. 
Para demonstrar o estágio global de acompanhamento dos riscos, a Tabela 2 mostra o percentual de países, segregados pelo nível de desenvolvimento e renda, que adotam exigências de capital para cobertura de riscos.

Tabela 2 - Percentual de países com requerimento de capital baseado em risco

\begin{tabular}{|l|c|c|c|c|c|}
\hline & \multicolumn{5}{|c|}{ RISCOS } \\
\cline { 2 - 6 } & Crédito & Mercado & Liquidez & Operacional & Sistêmico \\
\hline Desenvolvido & $95 \%$ & $65 \%$ & $20 \%$ & $5 \%$ & $5 \%$ \\
\hline Emergente & $81 \%$ & $30 \%$ & $8 \%$ & $8 \%$ & - \\
\hline Alta renda & $88 \%$ & $63 \%$ & $17 \%$ & $4 \%$ & $4 \%$ \\
\hline Média - Alta & $86 \%$ & $36 \%$ & $14 \%$ & $14 \%$ & - \\
\hline Média - Baixa & $76 \%$ & $38 \%$ & - & $10 \%$ & - \\
\hline Baixa renda & $93 \%$ & $7 \%$ & $14 \%$ & - & - \\
\hline Total & $85 \%$ & $40 \%$ & $11 \%$ & $7 \%$ & $1 \%$ \\
\hline Paraíso Fiscal & $75 \%$ & $17 \%$ & $8 \%$ & $8 \%$ & - \\
\hline
\end{tabular}

FONTE: OLIVEIRA, 2005, p.71.

Em geral, a exigência é mais representativa nos países desenvolvidos e de alta renda, com exceção do risco operacional que contém maior quantidade de países emergentes e de média renda. Salienta-se ainda, nesse quadro, que alguns países, particularmente os desenvolvidos, apresentam exigência de capital para o risco sistêmico.

No Brasil, a adesão aos princípios e às práticas estabelecidas pelos supervisores bancários dos países do G-10 15 , consubstanciados nos 25 Princípios Básicos do Comitê da Basiléia sobre Supervisão Bancária (BCBS, 1997a), tem sido paulatina e constante.

Atualmente, existem exigências de capital para a cobertura dos riscos de crédito, câmbio e taxa de juros. A implementação das recomendações do Comitê de Basiléia sobre Supervisão Bancária tem agregado maior segurança e estabilidade ao sistema financeiro.

\subsubsection{Avaliação de riscos}

Os modelos e as técnicas de avaliação podem ser agrupados de acordo com o tipo de risco mensurado, ou seja, subdividem-se entre os destinados a estimar o valor em risco de mercado e aqueles voltados para aferir o valor em risco de crédito.

15. Grupo formado por dez países: Alemanha, Bélgica, Canadá, França, Holanda, Itália, Japão, Suécia, Reino Unido e Estados Unidos, mais Luxemburgo e Suíça. 


\subsubsection{Avaliação do risco de mercado}

As técnicas de avaliação do risco de mercado estão em constante evolução. Atualmente, o instrumento mais utilizado para medir o risco de mercado é o valor em risco (VaR). O próprio Comitê de Basiléia sobre Supervisão Bancária recomenda o uso cálculo do VaR, tanto no modelo interno como na abordagem padronizada ${ }^{16}$, para alocação de capital destinado à cobertura do risco de mercado em bancos (BCBS, 1996) ${ }^{17}$.

A simplicidade de compreensão e a capacidade em responder diretamente a questão de quanto pode ser perdido, considerando certa probabilidade e período, disseminaram o uso do VaR. De acordo com Jorion (2003, p.95), “[...] a maior vantagem do VaR consiste em resumir, num único número de fácil compreensão, a exposição total ao risco de mercado de uma instituição."

Crouhy, Galai e Mark (2004, p.168) definem o VaR “[...] como a pior perda que poderia ser esperada em decorrência de se deter um título ou uma carteira por um dado período de tempo, dado um nível especificado de probabilidade.” Para fins de cálculo, os mesmos autores (2004, p.177) apresentam três abordagens diferentes.

A primeira, denominada analítica de variância-covariância, é considerada uma extensão do modelo de Markowitz (1952) e pressupõe que a volatilidade e o retorno tenham distribuição normal. Essa presunção simplifica os cálculos ao permitir o uso de poucos dados recentes na estimação do VaR.

A segunda abordagem é a simulação histórica e não impõe premissas analíticas sobre a distribuição. O cálculo da média do retorno e da pior perda possível é feito com base na distribuição dos retornos históricos. Dessa forma, a única exigência é dispor de significativa quantidade de dados.

A terceira abordagem é a simulação de Monte Carlo, que admite qualquer distribuição para as volatilidades. Escolhida a distribuição da volatilidade e definidos a correlação entre as variáveis, o tempo na posição e o nível de significância desejado, os retornos aleatórios são gerados mediante realização de inúmeras rodadas de simulação.

16. A autorização para utilização de modelos internos de VaR depende da qualificação da instituição.

17. Trata-se de um VaR ao nível de $99 \%$ de confiança, para um período de dez dias úteis. 
Em comum, as três abordagens compartilham a necessidade de um prazo, de um nível de significância, e das taxas e valores dos ativos e passivos existentes na carteira.

Como no estudo os dados utilizados são contábeis, sem a existência de longas séries históricas e não há presunção sobre a distribuição da volatilidade, o cálculo do VaR é realizado pela abordagem analítica.

Dessa forma, considerando que o VaR informa o valor da perda máxima que pode ocorrer em determinado prazo, dado um nível de confiança, a seguinte fórmula é usada:

$\operatorname{VaR}(H ; c)=V M^{*}\left(\mu-R^{\prime}\right)$

onde $H$ é o horizonte de tempo, $c$ é o nível de confiança, $V M$ é o valor de mercado da posição, $\mu$ é o retorno médio esperado e $R$ 'é a pior perda possível ao nível de confiança estabelecido.

Pelo exposto na fórmula, o importante é conhecer o retorno médio esperado e a pior perda possível para o nível de confiança.

Assumindo a normalidade dos retornos $(R)$, com média $\mu$ igual a:

$\mu=\frac{\sum R_{i}}{N}$

e desvio-padrão $\sigma$ igual a:

$\sigma=\sqrt{\frac{\sum\left(R_{i}-\mu\right)^{2}}{N}}$

o pior retorno é:

$R^{\prime}=\mu+\alpha^{*} \sigma$ 
onde $\alpha$ é o valor correspondente ao nível de confiança, obtido na tabela de distribuição normal padronizada unilateral ${ }^{18 .}$

Deste modo, para obter o valor em risco (VaR), basta substituir o R' na fórmula (6):

$\operatorname{VaR}(H ; c)=-\alpha^{*} \sigma^{*} V M$

Além de informar o valor em risco máximo de perda possível para um ativo, o VaR permite considerar a correlação existente entre dois ou mais ativos, passivos ou itens extrapatrimoniais, na forma concebida pela teoria das carteiras. Para tanto, o valor do desviopadrão a ser utilizado deve corresponder ao desvio-padrão dos dois itens juntos.

Exemplificando, supondo a aplicação em dois ativos diferentes $x$ e $y$, na proporção $w$, sendo $x+y=1$, desvio-padrão $\sigma$ e correlação $\rho$, o desvio padrão dos dois ativos que formam a carteira é obtido pela fórmula:

$$
\sigma_{x y}=\left[\left(w_{x}^{2} * \sigma_{x}^{2}\right)+\left(w_{y}^{2} * \sigma_{y}^{2}\right)+2 * w_{x} * w_{y} * \rho^{*} \sigma_{x} * \sigma_{y}\right]^{1 / 2}
$$

Caso os ativos sejam independentes, na situação em que os comportamentos não são relacionados e a correlação seja igual a zero $(\rho=0)$, o segundo termo da equação é zerado e o desvio torna-se simplesmente a soma dos desvios-padrão de cada ativo.

$\mathrm{Na}$ situação em que há correlação, a mudança no desvio-padrão depende do sinal da correlação, positivo ou negativo, e da posição patrimonial dos itens, ativa ou passiva. Para itens positivamente correlacionados, o desvio-padrão conjunto diminui quando os itens estão em posições contrárias, ativa e passiva. Encontrando-se na mesma posição ativa ou passiva, a correlação positiva faz o desvio-padrão conjunto aumentar.

Entre os modelos disponíveis no mercado, destaca-se o RiskMetrics (MORGAN, 1995), que calcula o valor em risco com base no valor da exposição e na volatilidade do preço (SAUNDERS, 2000, p.179).

18. Ver em Downing e Clark (1998, p. 448). 


\subsubsection{Avaliação do risco de crédito}

Paralelamente ao risco de mercado, os estudos sobre o risco de crédito também avançam constantemente a fronteira do conhecimento. O desafio atual é tratar o risco de crédito de forma agregada, como é feito para o risco de mercado. Acadêmicos e profissionais da área de riscos procuram desenvolver modelos cada vez mais abrangentes e integrados à realidade.

Caouette, Altman e Narayanan (1999, p.122), ao descrevê-los funcionalmente, fazem a separação de acordo com o segmento-alvo, como os modelos de risco voltados para o crédito corporativo, baseado em preço de ações, para o crédito ao consumidor, e para o crédito destinado a pequenas empresas, crédito imobiliário e instituições financeiras.

Entre os modelos baseados em dados contábeis, o comumente referenciado é o Z-escore, de Altman (1977). Aplicando análise discriminante sobre um grupo de indicadores de empresas comerciais e industriais, o autor discriminou as empresas solventes das insolventes. Esse modelo é referência ao desenvolvimento de inúmeros estudos relacionados à classificação em dois grupos distintos.

Diferentemente, Crouhy, Galai e Mark (2004, p.382) e Souza e Aragão (2003, p.404) segregam os modelos de avaliação do risco de crédito de acordo com as premissas metodológicas do desenvolvimento. Para os autores, os principais modelos são o KMV (KEALHOFER; BONH, 2001), o CreditMetrics (MORGAN, 1997), o CreditRisk+ (CREDIT SUISSE FIRST BOSTON, 1997) e o CreditPortfolio View (WILSON, 1997a,b).

Considerando a metodologia empregada, o Credit Portfolio View merece destaque pela utilização de variáveis econômicas como o crescimento do PIB (produto interno bruto), nível de taxas de juros e de câmbio, poupança, taxa de desemprego e despesas governamentais para simular ciclos econômicos, os quais são associados com a probabilidade de inadimplência e de migração da qualidade do crédito.

Conforme descrevem Crouhy, Galai e Mark (2004, p.309), a associação das probabilidades de inadimplência com as variáveis econômicas é feita com a aplicação de uma função logística (LOGIT), na qual a variável dependente é a probabilidade de inadimplência e as variáveis independentes são as variáveis econômicas. 
Essa interessante associação entre as variáveis econômicas e a inadimplência está em consonância com a proposta metodológica do presente estudo.

Independentemente das diferentes metodologias empregadas, Souza e Aragão (2003, p. 400) explicam que a perda esperada em uma operação de crédito é resultante da multiplicação da posição líquida pela probabilidade de inadimplência, devendo ser aprovisionado. No mesmo sentido, a perda não-esperada é incerta e advém da variação da taxa de inadimplência, isto é, do desvio-padrão.

Da mesma forma, Caouette, Altman e Narayanan (1999, p. 221, 295) consideram que o “ingrediente-chave" do risco de crédito é o risco de inadimplência e que o cálculo do valor em risco para um único ativo depende apenas da volatilidade histórica do ativo.

A junção dessas duas assertivas permite concluir que a volatilidade da taxa de inadimplência pode ser utilizada para calcular o VaR de crédito das carteiras, igualmente ao cálculo do VaR para risco de mercado.

Finalmente, Crouhy, Galai e Mark (2004, p.284) corroboram essa proposição ao resumir a forma de cálculo do valor em risco para crédito:

O VaR de crédito de uma carteira é então obtido de forma semelhante ao de risco de mercado. É apenas a distância da média ao percentil da distribuição futura, no nível de confiança desejado. (Essa definição se aplica a todos os modelos de risco de crédito e é independente da estrutura teórica subjacente).

Pelo exposto, analogamente ao cálculo do VaR para risco de mercado, é possível calcular o VaR para risco de crédito pela seguinte fórmula:

$\operatorname{VaR}(H ; c)=-\alpha * \sigma_{T I}^{*} \operatorname{VExpCré}$

onde $H$ é o horizonte de tempo, $c$ é o nível de significância, $\alpha$ é o valor correspondente ao nível de significância desejado estabelecido na tabela de distribuição normal padronizada, $\sigma_{T I}$ é o desvio-padrão da taxa de inadimplência e $V E x p C r e ́$ é o valor exposto ao risco de crédito. 


\subsubsection{Diferenciação entre perda esperada e não-esperada}

Um aspecto que merece atenção é a diferenciação existente entre a perda esperada e a perda não-esperada. Enquanto a perda esperada representa a média, a perda não-esperada está no desvio dos valores em relação a essa média.

A razão da diferença entre os conceitos é que as perdas efetivas ocorridas nem sempre são iguais aos valores médios esperados. Resumidamente, a perda não-esperada é definida como uma incerteza em relação à perda esperada.

Pelos números da Tabela 3, considerando a distribuição normal da taxa de inadimplência, há $68 \%$ de chances, área correspondente a um desvio-padrão ${ }^{19}$, da perda-não esperada estar no intervalo entre 50 e 150 unidades.

\section{Tabela 3 - Exemplo numérico da perda esperada e não-esperada}

\begin{tabular}{|l|c|c|}
\hline Exposição & A & 1.000 \\
\hline Taxa de inadimplência média & B & $10 \%$ \\
\hline Desvio-padrão & C & $5 \%$ \\
\hline Perda esperada & A X B & 100 \\
\hline Perda não-esperada & A X C & 50 \\
\hline
\end{tabular}

Entretanto, faz-se importante observar que o limite crítico para a perda-não esperada ocorre em um dos lados, sendo denominado limite unilateral ${ }^{20}$. Logo, somente os valores acima da média necessitam de alocação adicional de capital.

Por esse motivo, considera-se a área de $84,13 \%$, correspondente a um desvio-padrão $(\mathrm{z}=1,00)$ na tabela de distribuição padronizada unilateral (DOWNING; CLARK, 1998, p.447), e não a área de $68 \%$ da distribuição padronizada bilateral (duas caudas).

Caso o intervalo de confiança desejado fosse elevado para $95 \%$, o valor correspondente na tabela de distribuição padronizada seria $1,65(\mathrm{z}=1,65)$, e o montante da perda não-esperada aumentaria para 82,5 (1,65 x 50), com o limite crítico atingindo 182,5.

A demonstração gráfica da perda esperada, não-esperada e excepcional, exposta na Figura 1, permite visualizar melhor a relação com o patrimônio líquido ${ }^{21}$. 


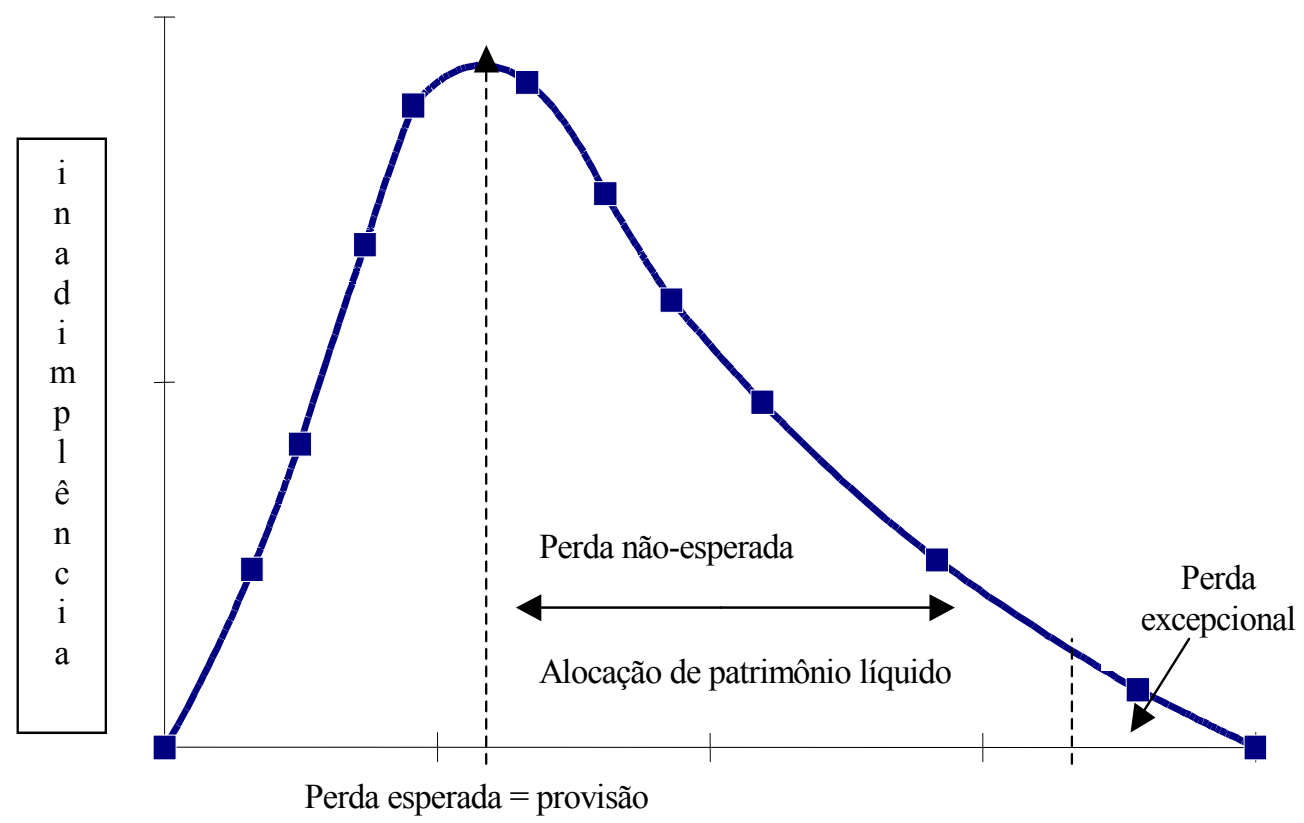

Figura 1 - Diferenças entre perda esperada, não-esperada e excepcional FONTE: Adaptado de BESSIS, 1998, p.71

Para fins de compreensão da relação entre o patrimônio líquido e a perda não-esperada, representada pelo VaR, as seguintes premissas precisam estar bem sedimentadas (BESSIS, 1998, p. 241):

a) o patrimônio líquido deve ser capaz de absorver os desvios das perdas médias esperadas;

b) os desvios das perdas médias constituem as perdas não-esperadas e são definidos de acordo com um nível de tolerância subjetivo, denominado nível de confiança;

c) os desvios das perdas médias que excedam o limite de tolerância são perdas excepcionais e não são programados para serem absorvidos pelo patrimônio líquido. Quando ocorrem, em princípio, a instituição está insolvente.

Em termos contábeis, há constituição de provisão para a perda esperada e alocação de capital para a perda não-esperada.

21. O termo também é conhecido como capital econômico ou CAR (Risk based capital). 


\subsubsection{Aspectos contemplados pelas variáveis econômicas}

As variáveis econômicas contêm informações agregadas da economia de países e por isso são também conhecidas como macroeconômicas. São utilizadas para avaliar diversos aspectos como crescimento, produção, investimentos, endividamento interno e externo, capacidade de pagamento, taxas de juros e de câmbio, saldos em reservas internacionais e em conta corrente, exportações e importações, poupança e crédito, inflação, enfim, todos os parâmetros necessários à análise econômica de um país ou região (IMF, 1996) ${ }^{22}$.

Apesar de estarem interligadas e as mudanças em quaisquer delas serem prontamente refletidas nas demais, os estudos sobre crises financeiras mostram que algumas variáveis econômicas são mais freqüentes no processo de identificação de crises (KAMINSKY, LIZONDO e REINHART, 1998).

a) Produto Interno Bruto (PIB)

O PIB contém a informação do fluxo de riqueza gerado dentro de um país no período de um ano e sintetiza a capacidade produtiva.

Para fins de cálculo do PIB, a Economia utiliza três diferentes enfoques (ROSSETTI, 1982, p.523). Um baseado na produção, no qual são somados todos os bens e serviços produzidos, excetuando-se aqueles das fases intermediárias de produção. Nesse particular, a DVA (demonstração do valor adicionado) ${ }^{23}$ é fundamental ao cálculo do valor agregado, pois explicita a informação da contribuição de cada entidade ao produto.

Outra forma de cálculo consiste no somatório de todas as remunerações recebidas pelas pessoas físicas e jurídicas, públicas e privadas, no processo produtivo. Como o anterior, exclui os pagamentos relativos aos intermediários do processo produtivo. Apenas a remuneração paga ao produto agregado é considerada no cálculo.

22. Em 1996, o IMF estabeleceu orientações para a divulgação padronizada de informações econômicas e financeiras aos países participantes, ou com intenção de participar, do mercado financeiro internacional.

23. A demonstração do valor adicionado está prevista como obrigatória para determinadas empresas no Projeto de Lei n.3.471, que pretende modificar a Lei 6.404, de 15 de dezembro de 1976. 
Finalmente, o terceiro método de cálculo do PIB é com base no dispêndio. Como o dispêndio divide-se em consumo e investimento, todos os valores consumidos e investidos pelas pessoas físicas e jurídicas, públicas e privadas, entram no cômputo do agregado.

Em termos de análise, a discrepância entre o saldo dessa variável e o valor contábil dos ativos do sistema financeiro pode ser motivo de desconfiança aos agentes quanto à capacidade de realização dos ativos financeiros em ativos reais.

A percepção da inferioridade no montante de PIB pode desencadear a transformação dos ativos financeiros em ativos reais ou em moedas estrangeiras emitidas por países com maior estabilidade econômica, provocando a queda no valor dos ativos e conseqüentes prejuízos.

Adicionalmente à relação direta com o PIB, nas datas de balancete e balanço, a volatilidade dos ativos financeiros contém valiosa informação sobre o risco, pois não basta a equivalência entre os montantes, mas também a estabilidade na proporção dos ativos financeiros e o PIB ao longo do tempo. Assim, o desvio-padrão dos ativos financeiros é considerado na relação com o PIB.

b) Taxa de juros

A taxa de juros é uma das principais variáveis econômicas a causar impacto sobre as demonstrações contábeis. Usualmente, é definida como o custo do dinheiro no tempo.

Para manter equilíbrio entre o volume de moeda e o nível de produção, a taxa de juros é administrada no contexto da política econômica pela autoridade monetária, geralmente um banco central.

As decisões de comprar ou vender moeda são influenciadas pela taxa de juros e afetam diretamente a liquidez do mercado. A redução ou o aumento da oferta de moeda em circulação provoca reflexos em toda economia.

O objetivo é mantê-la em patamar adequado aos objetivos traçados para a atividade econômica do país. A taxa de juros praticada pelo governo serve de parâmetro aos demais agentes econômicos no estabelecimento de estratégias e metas de crescimento. 
Nas situações em que a taxa de juros administrada pelo governo não corresponde às expectativas dos agentes econômicos, a taxa de juros praticada pelo mercado serve de melhor instrumento à avaliação.

De acordo com o interesse de diminuir ou aumentar a quantidade de moeda em circulação, a taxa de juros é elevada ou reduzida, respectivamente. Nesse sentido, Keynes (1988, p.120) explica:

\begin{abstract}
A taxa de juros não é o preço que equilibra a demanda de recursos para investir e a propensão de abster-se do consumo imediato. É o preço mediante o qual o desejo de manter a riqueza em forma líquida se concilia com a quantidade de moeda disponível. Isso implica que, se a taxa de juros fosse menor, isto é, se a renúncia à liquidez se reduzisse, o montante agregado de moeda que o público desejaria conservar excederia a oferta disponível e que, se a taxa de juros se elevasse, haveria um excedente de moeda que ninguém estaria disposto a reter.
\end{abstract}

Assim, a redução da taxa de juros no ciclo financeiro funciona como incentivo a maior produção de ativos reais e, inversamente, a elevação torna o custo de oportunidade elevado para esses ativos reais, induzindo os recursos para o ciclo financeiro.

A mensuração do impacto das variações é feita pelo cômputo da volatilidade da taxa de juros sobre as variáveis contábeis expostas à taxa de juros.

c) Taxa de câmbio

A taxa de câmbio é outra variável econômica com efeito significativo sobre as demonstrações contábeis quando há exposições em câmbio, na medida em que expressa o valor da moeda do país em relação à moeda estrangeira.

O nível das reservas internacionais, o saldo líquido da balança comercial, o saldo em contacorrente, o endividamento externo, especialmente de curto prazo, e a própria taxa de inflação interna são os fatores determinantes da paridade da moeda do país com a moeda estrangeira.

Qualquer alteração nas variáveis econômicas relacionadas traz conseqüências ao equilíbrio monetário, que precisa ser restabelecido pela atuação sobre a taxa de juros ou mesmo sobre a taxa de câmbio. 
Similarmente à taxa de juros, alterações na taxa de câmbio causam impacto sobre as variáveis contábeis expostas à variação cambial. Como é normal a manutenção de posições ativas e passivas em moeda estrangeira pelos bancos, uma desvalorização na moeda do país (valorização na taxa de câmbio), por exemplo, com vistas a criar incentivo às exportações e conseqüente aumento das reservas internacionais, pode repercutir em maior risco de crédito para as operações ativas indexadas em moeda estrangeira e, também, maior endividamento da instituição financeira, pelo aumento do passivo.

O regime de taxa de câmbio usualmente adotado pelos países é fixo, administrado em faixas ou flutuante (livre). Entretanto, assim como na taxa de juros, quando os agentes não reconhecem a taxa de câmbio fixada pelo governo como legítima, operam com uma taxa de câmbio referencial paralela.

A mensuração do impacto das variações é feita pelo cômputo da volatilidade da variação da taxa de câmbio sobre a posição contábil líquida em moeda estrangeira.

\section{d) Reservas internacionais}

O saldo de reservas internacionais constitui o valor disponível em moeda estrangeira mantido por determinado país. O valor é relevante por conter informação sobre a capacidade de geração de divisas e de pagamento. Representa também a garantia de conversibilidade da moeda do país para a moeda estrangeira, funcionando assim como um atrativo aos investimentos. A escassez de reservas pode significar maior risco às operações realizadas em moeda estrangeira.

A principal fonte de formação das reservas é a diferença entre as exportações e importações, embora contenha os valores correspondentes aos investimentos diretos, empréstimos, financiamentos e captações de recursos externos.

Em termos de análise, as reservas são habitualmente comparadas com o montante de importações, visto que servem como garantia de pagamento. Entretanto, outras comparações são igualmente densas em informações como as realizadas com os investimentos em títulos e valores mobiliários (mercado financeiro) ou com o crescimento do PIB. 
No tocante ao relacionamento com as variáveis contábeis, as reservas estão limitadas aos saldos ativos e passivos em moeda estrangeira. Dado o impacto direto da taxa de câmbio sobre as mesmas variáveis contábeis, as reservas foram deixadas como fontes secundárias para calcular a variação cambial.

\section{e) Conceito econômico do M2}

O M2 é formado pelo conceito econômico do M1, papel moeda em poder do público mais depósitos à vista, adicionado pelos depósitos especiais remunerados, depósitos de poupança e títulos emitidos por instituições depositárias.

Alterações no volume dos meios de pagamento, pelo conceito M2, pode representar escassez ou abundância de moeda, com reflexos sobre o montante de ativos líquidos e depósitos, expondo o sistema bancário à instabilidade no curto prazo. Por esse motivo, as autoridades monetárias acompanham a evolução desse agregado monetário.

A adoção da premissa de que a probabilidade de ocorrer falta de ativos líquidos para cumprir as obrigações de curto prazo representa o risco de liquidez permite mensurar o impacto pelo cômputo da volatilidade do M2 sobre os ativos líquidos.

Entretanto, como o M2 contém o valor do papel moeda em poder do público e os depósitos representam melhor essa informação contabilmente, houve a preferência de calcular o risco de liquidez com base na razão entre a volatilidade dos depósitos e o volume de ativos líquidos.

\subsubsection{Aspectos contemplados pelas variáveis e indicadores contábeis}

\subsubsection{Variáveis}

Diferentemente das variáveis econômicas, as variáveis contábeis são raramente encontradas nos estudos sobre crises financeiras. A utilização de variáveis contábeis para avaliação de sistemas financeiros ainda está restrita aos órgãos de supervisão.

Os principais componentes analisados para avaliar a situação econômico-financeira de instituições e sistemas financeiros, de acordo com o IMF (2001a, p.11) e Worrel (2004, p.5), 
estão contidos na estrutura analítica reconhecida como CAMELS $^{24}$, considerada a metodologia de avaliação mais utilizada pelos órgãos de supervisão.

Os seis componentes do CAMELS estão relacionados à adequação do capital, qualidade dos ativos, capacidade gerencial, resultados, liquidez e sensibilidade ao risco.

Como a avaliação da capacidade gerencial não pode ser feita exclusivamente pelas variáveis quantitativas, pois depende da observação de aspectos qualitativos relacionados aos controles internos e ao conhecimento técnico dos gestores, o componente não integra este estudo.

Para melhor compreensão, as seguintes informações estão contempladas em cada componente (IMF, 2001a; EVANS et al., 2000):

a) Adequação de capital

O montante de capital existente, definido como o valor do patrimônio líquido, estabelece, em última instância, o quanto de risco é suportado para determinado nível de operações. A robustez da instituição financeira depende da qualidade do capital para absorver prejuízos. A extensão desse conceito para o sistema permite considerar o valor agregado do capital das instituições como um importante sinalizador da estabilidade e solidez do sistema.

Assim, o comportamento do capital deve ser constantemente monitorado, pois evidencia tanto aspectos quantitativos, em termos de volume e crescimento, como qualitativos, quando serve de referencial à assunção de operações com risco ${ }^{25}$.

O perecimento ou o comprometimento do capital, independentemente da causa, significa problemas na situação econômica e conseqüente aumento de exposição ao risco.

24. O Uniform Financial Institutions Rating System (UFIRS), mais conhecido pelo acrônimo CAMELS, foi desenvolvido pelo Federal Financial Institutions Examination Council, composto pelos supervisores bancários norte-americanos, e adotado a partir de 20/12/1979, com a alteração da SR 96-38, de 27/12/1996. Contempla os seguintes itens: Capital, Assets (Ativos), Management (Capacidade Gerencial), Earnings (Resultados), Liquidity (Liquidez) e Sensitivity (Sensibilidade aos Riscos). Disponível em http://www.federalreserve.gov.

25. O aspecto qualitativo é verificado pela composição do capital, que pode ser proveniente de recursos integralizados e lucros (Tier 1), da reavaliação de ativos e dos ajustes positivos a valor de mercado (Tier 2), e das dívidas emitidas a longo prazo, com cláusulas específicas (Tier 3). 
Como o valor do patrimônio líquido é obtido pela diferença entre o ativo e o passivo, o seu valor é diretamente influenciado pelos critérios de avaliação dos ativos e pelas regras de classificação dos empréstimos e de constituição das provisões.

b) Qualidade dos ativos

A situação econômico-financeira das instituições depende diretamente do volume e da qualidade dos ativos administrados. O processo de insolvência tem origem, normalmente, na incapacidade de os ativos gerarem receitas suficientes para cobrir as despesas, podendo ser conseqüência tanto do baixo volume operacional como da má qualidade dos ativos.

A análise da composição e da evolução da estrutura do ativo, mediante verificação de itens como os ativos líquidos, as operações de crédito, em situação normal ou não, e o volume de ativos em moeda estrangeira, permite conhecer o direcionamento operacional e o nível de qualidade. Nesse particular, o acompanhamento da participação das operações de crédito vencidas é essencial à correta avaliação.

c) Resultados

A capacidade de gerar resultados é determinante à continuidade das instituições e do sistema financeiro sob o regime capitalista. O resultado líquido é a síntese dos esforços despendidos em cada instituição em determinado período.

Em condições de mercado, somente instituições e mercados geradores de excedentes reúnem condições de funcionamento. Prejuízos constantes representam riscos adicionais à continuidade operacional.

Dessa forma, o volume de resultados auferido pelo sistema bancário de cada país constitui em variável essencial à avaliação do desempenho. Somente em casos excepcionais, quando não há informação contábil ou existem critérios desconhecidos de apropriação de receitas e despesas em contas de resultado, faz sentido considerar o valor do resultado líquido como a variação do patrimônio líquido de um período para outro ${ }^{26}$.

26. Nessa situação, a variação no Patrimônio líquido é decorrência exclusiva do resultado do período. 
No estudo, considerando a relativa homogeneização existente no setor bancário, não há motivos para prescindir do item contábil representativo dos resultados e utilizar o indicador que expressa a rentabilidade do patrimônio líquido (ROE) como variável de análise.

d) Liquidez

A liquidez é outro item de freqüente preocupação em instituições financeiras, pois revela tanto problemas causados pela má qualidade do crédito e falta de recebimentos, como os motivados pela perda abrupta de depósitos. Em ambas as situações, a liquidez aparece como sinalizadora, muitas vezes terminal, de problemas.

A característica da atividade operacional de intermediação financeira expõe naturalmente o sistema bancário ao risco liquidez. A possibilidade de resgate dos recursos captados, principalmente na forma de depósitos, em qualquer tempo, e as aplicações em prazos prédefinidos, geram potenciais descasamentos de prazos que podem refletir em dificuldades extemporâneas de liquidez.

Em situação de normalidade, o sistema administra a diferença de prazos, pois conhece o montante médio de recursos mantido em depósitos e, consequentemente, o volume de saques. Com base nisso, controla o montante de aplicações em ativos líquidos necessário para honrar as prováveis retiradas.

Entretanto, em momentos de turbulência, os saques podem ocorrer em patamar superior ao esperado e os ativos líquidos tornarem-se insuficientes. Nesse cenário, as opções das instituições depositárias são a realização de outros ativos, com perda de rendimento, a obtenção de outras fontes de recursos para substituir os valores sacados e a assistência financeira da autoridade monetária.

Perante essa fragilidade comum ao sistema bancário, métodos precisos para a mensuração da liquidez foram desenvolvidos, baseados no monitoramento dos dados diários das contas de reserva bancária ou, ainda, no acompanhamento das taxas pagas aos depósitos interbancários. 
Em termos contábeis, contudo, as informações estão limitadas às datas das demonstrações contábeis e encontram-se concentradas nas variáveis representativas dos ativos líquidos, depósitos à vista e depósitos a prazo.

e) Sensibilidade ao risco de mercado

O componente de sensibilidade ao risco de mercado reflete o grau em que alterações nas taxas de juros e câmbio, preços de ações e commodities afetam adversamente os resultados ou o capital de uma instituição financeira.

A completa avaliação deste componente também é condicionada à verificação da capacidade de gerenciamento dos riscos, à natureza e à complexidade das operações e ao tamanho da instituição, bem como ao volume de capital e de resultados em relação à exposição ao risco de mercado.

Para muitas instituições, a principal fonte de risco de mercado é a posição sensível a mudanças nas taxas de difícil negociação. A avaliação deve ser feita de forma integrada, levando em consideração tanto o risco de mercado como a capacidade de gerenciá-lo.

As variáveis contábeis são afetadas diretamente pelos riscos de crédito e de mercado, especialmente os de câmbio e de taxa de juros. Quaisquer alterações nas variáveis determinantes dos riscos têm conseqüências sobre os valores contábeis expostos.

Segundo Bessis (1998, p.51), os métodos existentes para verificar a influência dos riscos sobre as variáveis podem ser divididos em três grupos:

i. Sensibilidade, que captura o desvio do objetivo pela variação em uma taxa de mercado. Por exemplo, o desvio do resultado líquido projetado em face da modificação na taxa de juros em $1 \%$.

ii. Volatilidade, que captura as variações em torno da média de qualquer variável, positivas e negativas. Por exemplo, a taxa de câmbio em determinado período apresenta variação média igual a 10\% e desvio-padrão igual a 5\%. Pela informação, a variação esperada da posição em moeda estrangeira é de $10 \%$, podendo, entretanto, flutuar entre 5\% e 15\%. 
iii. Medidas de Risco de Perda ${ }^{27}$, que captura apenas os desvios que representam despesas. Condicionando o exemplo anterior à existência de uma obrigação líquida, em moeda estrangeira, o interesse está no desvio positivo de 5\%, pois implica elevação do valor devido e conseqüente aumento da despesa. O desvio de 5\% negativo representa ganho e não é considerado na avaliação de risco.

Entre essas medidas, o método da volatilidade é o mais associado à forma de avaliação de riscos pelo $\mathrm{VaR}$, pois independentemente das posições assumidas, o método retorna a variação em torno da média e quanto isso pode representar do patrimônio líquido.

Dessa forma, a sensibilidade ao risco dos itens patrimoniais é calculada pelo VaR das posições expostas a cada um dos riscos.

\subsubsection{Indicadores}

Conforme mencionado, mesmo com a forte correlação entre a economia e o sistema financeiro, os estudos privilegiam o uso de indicadores formados por variáveis econômicas, em detrimento do uso de variáveis contábeis, na avaliação do risco sistêmico e na previsão de crises.

Todavia, o uso de informações contábeis para avaliar a situação econômico-financeira de empresas individualmente é bastante difundido, podendo ser estendido à avaliação da situação e dos riscos do sistema financeiro.

Nesse sentido, o IMF, em seus trabalhos de monitoramento, assistência técnica e definição de políticas de desenvolvimento, tem como arcabouço analítico um conjunto de indicadores referentes ao desempenho do sistema financeiro e da economia, chamados de MPI (Macroprudential Indicators) ou FSI (Financial Soundness Indicators).

Entre o conjunto, doze indicadores são recomendados como essenciais à avaliação das instituições financeiras depositárias (IMF, 2004b, p.114), a saber:

27. Tradução de "downside measures of risk" (BESSIS, 1998, p.51). 
a) Capital total regulamentar para cobertura de ativos ponderados pelo risco;

b) Capital nível 1 para cobertura de ativos ponderados pelo risco;

c) Créditos vencidos líquidos de provisão sobre o capital;

d) Rentabilidade do capital;

e) Posição líquida em moeda estrangeira sobre o capital;

f) Ativos líquidos sobre o ativo total;

g) Ativos líquidos sobre as dívidas de curto prazo;

h) Rentabilidade do ativo;

i) Créditos vencidos sobre o total de operações de crédito;

j) Distribuição setorial de créditos sobre o total de operações de crédito (concentração);

k) Margem financeira (resultado de intermediação financeira sobre as receitas); e

1) Despesas administrativas sobre as receitas.

Com o objetivo de identificar pontos fortes e vulnerabilidades nos sistemas financeiros e minimizar a probabilidade de crises financeiras, o IMF tem usado esses indicadores contábeis, bem como os indicadores macroeconômicos, para avaliar a evolução do PIB, do balanço de pagamentos, da inflação, das taxas de juros e de câmbio, das reservas internacionais, dos investimentos estrangeiros diretos, do montante de crédito, entre outros.

Enquanto a análise macroprudencial enfoca a solidez e a estabilidade do sistema financeiro, a análise microprudencial aborda a situação individual das instituições. Em estudos sobre a estabilidade de sistemas financeiros, o IMF utiliza um modelo integrado por variáveis relevantes tanto para a avaliação individual como do sistema financeiro, conforme demonstrado na Figura 2.

Essa prática corrobora o posicionamento do IMF (2001a, p. 7) quando afirma que: “[...] há clara ligação entre a análise macroprudencial e sistemas de alerta e outros instrumentos analíticos para monitorar as vulnerabilidades e prevenir crises." 28

28. Tradução de "there are clear linkages between macroprudential analysis and early warning systems and other analytical tools to monitor vulnerabilities and prevent crises." 


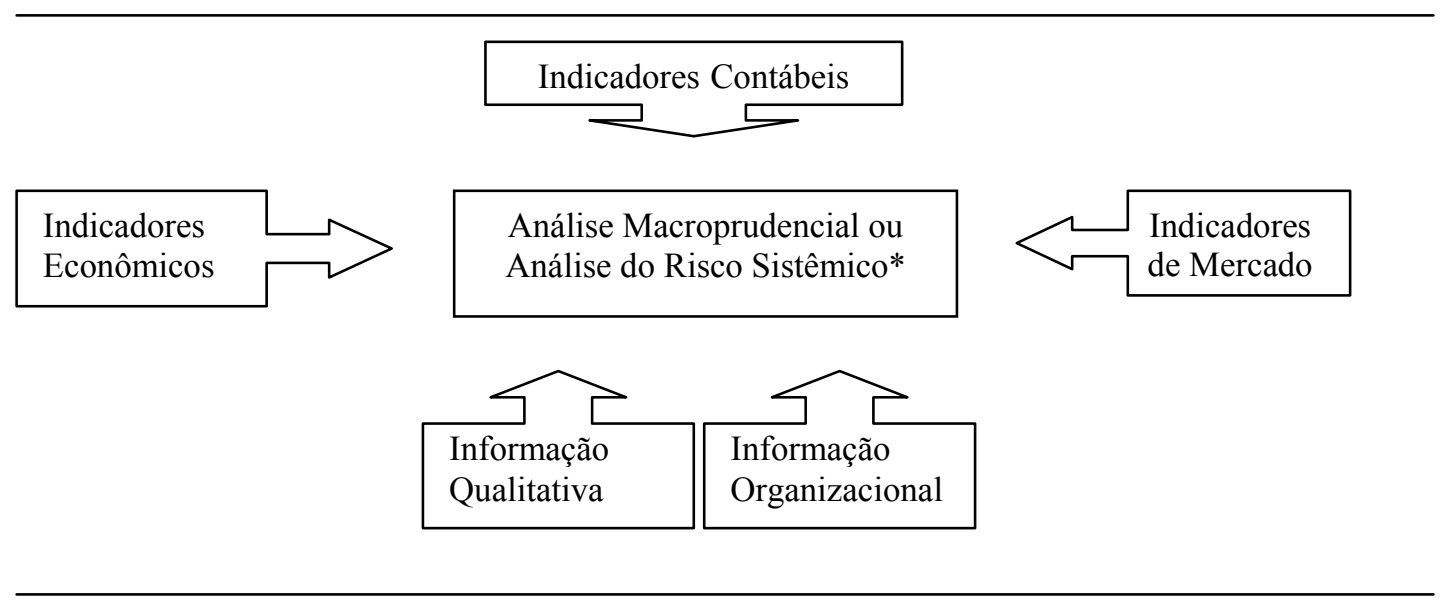

Figura 2 - Componentes da análise macroprudencial

FONTE: IMF (2001a, p.6)

* Inclusão do autor

\subsubsection{Relação entre o sistema financeiro e as variáveis econômicas}

A ligação entre o sistema financeiro e a economia real é originada nas propriedades clássicas da moeda como reserva de valor e intermediária de troca. Os balanços das instituições financeiras, especialmente dos bancos comerciais, são os detentores das informações sobre o processo de alocação e de transferência dos recursos e riscos na economia.

Haja vista a significativa parcela dos meios de pagamento depositada no sistema financeiro bancário, exposta na Tabela 4, e considerando a equação de Fisher (1911 apud BRUE, 2005, p. 307):

$M * V=P^{*} T$

onde $\mathrm{M}$ é a quantidade de moeda disponível, $\mathrm{V}$ é a velocidade de circulação da moeda, $\mathrm{P}$ é o preço praticado e $\mathrm{T}$ a quantidade de bens e serviços transacionados, o volume e a magnitude das operações realizadas pelos intermediários financeiros precisam ser constantemente monitorados e calibrados, de forma a evitar surtos inflacionários ou recessivos.

O valor do papel-moeda em poder do público representa apenas 3,7\% do total dos meios de pagamento (M4). Todo o restante, 96,3\%, está aplicado em depósitos ou títulos, de acordo 
com a composição dos meios de pagamento M1, M2, M3 e M4 ${ }^{29}$.

Tabela 4: Valores da base monetária e dos meios de pagamento - 30.06.2005 - R\$ milhões

\begin{tabular}{|l|c|c|c|c|c|}
\hline Data & \multicolumn{5}{|c|}{ Meios de Pagamentos } \\
\hline 2005 & M1-PMPP & M1-DV & M2 & M3 & M4 \\
\hline Junho & 43.591 & 73.812 & 513.006 & 1.047 .306 & 1.184 .951 \\
\hline
\end{tabular}

PMPP $=$ Papel-moeda em poder público; $\mathrm{DV}=$ Depósitos à vista.

FONTE: BANCO CENTRAL DO BRASIL - Boletim de setembro de 2005, vol.41 n.9.

A possibilidade de uma unidade monetária transformar-se em várias unidades, em virtude do efeito multiplicador da moeda ${ }^{30}$, obriga a regulação da quantidade de moeda em circulação, via administração da taxa de juros ${ }^{31}$.

$\mathrm{O}$ aumento nos meios de pagamento não acompanhado pelo crescimento econômico gera desconfiança sobre o poder de compra da moeda, podendo ensejar "corridas bancárias", aumento de preços e finalmente crises monetárias.

Outra variável que relaciona o setor financeiro à produção real é a taxa de câmbio. Dado o grau de dependência aos recursos externos e o relacionamento comercial com o exterior, observado no volume de importações e exportações, a taxa de câmbio exerce maior ou menor influência na política monetária.

$\mathrm{Na}$ medida em que o sistema financeiro é responsável pela maior parte das captações e aplicações em moeda estrangeira, ou a ela referenciados, as posições ativas e passivas implicam risco de câmbio para o sistema.

Além da influência das taxas sobre os ativos e os passivos do sistema financeiro, outro elo

29. Conceitos utilizados no Brasil. Disponível em http://www.bcb.gov.br/ftp/infecon/NM-MeiosPagAmplp.pdf. M1 = papel moeda em poder do público + depósitos à vista; M2 =M1 + depósitos especiais remunerados + depósitos de poupança + títulos emitidos por instituições depositárias; M3 = M2 + quotas de fundos de renda fixa + operações compromissadas registradas no Sistema Especial de Liquidação e Custódia (Selic); M4 = M3 + títulos públicos de alta liquidez.

30. A fórmula de cálculo do efeito multiplicador é $K=\frac{1}{\frac{P M P P}{M 1}+\frac{D V}{M 1}\left(\frac{C X}{D V}+\frac{R B}{D V}\right)-\frac{M 1}{B M}}$; onde PMPP é o papel-moeda em poder público, DV é o depósito à vista, CX é o encaixe livre depositado no banco central, RB é a reserva bancária e BM é a base monetária.

31. Além do controle da taxa de juros, os bancos centrais utilizam, para fins de política monetária, o recolhimento compulsório, o redesconto e o "open market". 
importante é o volume de crédito concedido pelo sistema financeiro, cujo conceito econômico é o da demanda agregada. O volume de operações de crédito, comparativamente ao nível de produção, à poupança e aos meios de pagamento, serve de insumo à gestão das taxas de juros e de câmbio, bem como à política fiscal.

Finalmente, a principal prova de ligação entre o setor financeiro e a moeda reside na premissa de que a credibilidade e a estabilidade da moeda dependem da existência de um sistema bancário igualmente crível e estável. Não existe moeda forte sem um sistema financeiro igualmente forte (LUNDBERG, 1999).

\subsection{Estudos sobre crises sistêmicas no sistema financeiro}

O risco sistêmico no setor financeiro é um tema altamente atrativo e fecundo para pesquisas, em face da abrangência e repercussões econômicas e sociais que um colapso proporcionado por uma crise pode causar.

As pesquisas de Kaminsky, Lizondo e Reinhart (1998), Flood e Marion (1998) e De Bandt e Hartmann (2000) contêm extensiva e detalhada revisão dos estudos sobre risco sistêmico, os quais são apresentados resumidamente. A profusão de modelos para explicar crises foi obtida mediante a utilização de diferentes variáveis explicativas e técnicas estatísticas.

Usualmente, a literatura classifica os estudos em dois grandes grupos, de acordo com o método dedutivo ou indutivo empregado. Nessa linha, De Bandt e Hartmann (2000) classificam os estudos como teóricos e empíricos, os quais podem analogamente corresponder aos enfoques dedutivo e indutivo, respectivamente.

O enfoque teórico propõe modelos suportados por uma teoria subjacente capaz de explicar o comportamento das variáveis e a ocorrência das crises. Constitui-se em um método dedutivo onde há construção de uma parte da realidade com resultados previsíveis.

Apesar de proverem orientação sobre a escolha de variáveis potenciais, que reflitam os fundamentos ou quaisquer outras expectativas de mercado, os modelos teóricos não explicam a relevância que as variáveis deveriam receber para aferir a proximidade das crises. Além 
disso, como as variáveis estão confinadas a um modelo, dependem da máxima similaridade possível do modelo à realidade para obter resultados satisfatórios.

Em sentido oposto, o enfoque empírico é indutivo e procura encontrar as causas das crises por meio da aplicação de diversas metodologias em dados reais. Não obstante a nomenclatura, os estudos empíricos assumem premissas embasadas na teoria para explicar a utilização de variáveis e definir as hipóteses.

Nessa abordagem, as variáveis são selecionadas pela relevância e recebem ponderações de acordo com a capacidade de prever crises. O desafio é encontrar características comuns que permitam o máximo de generalização possível.

Como o objetivo é agregar conhecimentos sobre o risco sistêmico e a previsão de crises que subsidiem a pesquisa, a revisão contempla os dois grupos, com a descrição e a breve resenha dos principais estudos teóricos e empíricos.

\subsubsection{Modelos teóricos ou dedutivos}

A evolução dos modelos teóricos permite dividi-los igualmente em dois grupos. Um composto por aqueles que explicam as crises em virtude da fraqueza nos fundamentos macroeconômicos, chamados de modelos de "primeira geração"32, e outro formado pelos estudos que procuram explicações nos próprios agentes econômicos e variáveis do mercado, denominados modelos de "segunda geração".

A premissa desses modelos é que a política econômica não é previamente determinada, mas responde a mudanças na economia, sendo que os agentes levam isto em consideração para formar suas expectativas.

Ao mesmo tempo, as expectativas e as ações dos agentes econômicos afetam algumas variáveis para as quais as políticas econômicas tornam a responder. Ante o exposto, esses modelos sugerem que as crises são passíveis de ocorrer sem qualquer mudança nos

32. Definição usada por Flood e Marion (1998) para caracterizar modelos que mostram como a taxa de câmbio fixa combinada com políticas expansionistas levam à crise. Diferentemente, os modelos de segunda geração prevêem crises mesmo com fundamentos econômicos fortes, bem como o comportamento não-linear das variáveis. 
fundamentos econômicos, na medida em que os movimentos circulares enfatizam a natureza contingente das políticas econômicas, proporcionando o surgimento de múltiplos equilíbrios e a geração de crises auto-realizáveis.

A diversidade de variáveis utilizada na explicação do risco sistêmico e da crise financeira possibilita a identificação de outros subgrupos.

\subsubsection{Modelo baseado nos fundamentos econômicos}

Com referência aos estudos sobre crises monetárias motivadas pela fraqueza dos fundamentos econômicos, o modelo tradicional de Krugman (1979) mostrou que a taxa de câmbio fixa, conjugada com políticas monetária e fiscal expansionistas, é insustentável. A fixação da taxa em um ambiente de excessiva expansão do crédito, não acompanhado pela oferta de produtos, obriga a utilização de reservas internacionais para manter a paridade da moeda nacional em relação às moedas estrangeiras. Em estágio avançado, a desconfiança generalizada propicia o ataque contra a moeda que resulta no colapso cambial. Para o autor, as variáveis determinantes da crise, ou conseqüências, são a perda de reservas internacionais e a desvalorização cambial.

Avançando nas pesquisas, Flood e Garber (1984) e Obstfeld (1984) assumiram que o mercado de câmbio apresenta múltiplo equilíbrio por causa da natureza contingente da política econômica e está sujeito a ataques especulativos auto-realizáveis.

Não existindo ataques especulativos contra a moeda, as políticas fiscal e monetária estão em equilíbrio e a taxa de câmbio fixa não sofre pressões, podendo ser mantida indefinidamente. Somente quando a situação do mercado é incompatível com o regime de câmbio fixo, surge a oportunidade para o ataque especulativo, provocando alteração na política monetária para acomodar a desvalorização imposta à moeda local.

Nesse cenário, a tentativa de implementar ações defensivas de proteção à moeda, como a utilização das reservas internacionais, pode fomentar ainda mais os ataques especulativos, pois, conforme observado por Obstfeld (1984, p.16), “Ações do governo, previstas pelo 
mercado, podem levar a resultados indesejáveis em economias que funcionariam corretamente sem a implementação delas."33

Ainda voltado para estudos sobre a manutenção da taxa de câmbio fixa, Ozkan e Sutherland (1995) desenvolveram um modelo cuja função depende dos custos envolvidos. A decisão de elevar a taxa de juros para manter a taxa de câmbio fixa pode ser desvantajosa em determinadas condições. A elevação do custo da dívida pública mobiliária, por exemplo, dada a sua magnitude, pode representar um custo maior do que a liberalização da taxa de câmbio. Além disso, a manutenção da taxa de juros em patamares elevados incentiva a "desintermediação" financeira, prejudicando a oferta de crédito e o nível de produção, com conseqüente redução de empregos. Nesse cenário, o custo de desvalorizar o câmbio é preferível ao custo de socorrer o sistema, mediante o aumento da taxa de juros.

Vários outros estudos podem ser considerados extensões do modelo de Krugman (1979). Alguns apresentam como sinal para um ataque especulativo contra a moeda a existência de déficits nos saldos do balanço de pagamentos ou da balança comercial. Outros seguem a incerteza sobre o volume de crédito ou de reservas que o governo estaria disposto a perder para manter a paridade da moeda, dada a elevação na taxa de juros. Há também os que apontam a elevação de salários como causa de expectativa de crise futura, justificada pela perda de competitividade. Como síntese desses estudos, as variáveis relativas à taxa de câmbio, à taxa de juros, ao saldo da balança comercial e aos salários reais são as mais importantes para sinalizar as crises monetárias (KAMINSKY; LIZONDO; REINHART, 1998, p.4).

\subsubsection{Modelo clássico de “corrida bancária”}

O estudo seminal sobre "corrida bancária", com a utilização de testes empíricos, foi realizado por Diamond e Dybvig (1983). Para os autores, as crises são "profecias auto-realizáveis", nas quais as ações concretizam as previsões. Com base nisso, provêem uma explicação bastante simples para a "corrida bancária", baseada na constatação de que os depósitos de curto prazo captados pelos bancos são aplicados em investimentos de longo prazo e não há como restituílos antes do vencimento, sem a liquidação de ativos com prejuízos. Dessa forma, caso ocorra

33. Tradução de "Expected government actions may lead to undesired outcomes in economies that would function correctly otherwise." 
algum evento que provoque desconfiança aos depositantes, quanto à integridade dos seus depósitos, haja vista a redução no valor dos ativos pela liquidação antecipada, todos tendem a sacar seus recursos, agravando a situação e levando o banco à insolvência.

O modelo clássico de "corrida bancária" apresenta três conclusões importantes (DATZ, 2002, p. 9):

a) parte das economias permanece depositada nos bancos, mesmo com a possibilidade de corridas bancárias, em face da melhor capacidade gerencial dos bancos e da aleatoriedade do consumo;

b) a desconfiança no sistema pode gerar o "equilíbrio indesejável”, quando todos correm para sacar seus depósitos. A propagação pela assimetria de informações culmina no "efeito manada", quando todos tomam a mesma atitude, provocando a insolvência das instituições; e

c) as medidas de proteção aos depositantes podem eliminar o risco de ocorrência das corridas bancárias.

Faz-se importante notar que um banco de porte significativo, obrigado a vender seus ativos antes dos prazos de vencimento, afeta negativamente o valor de mercado dos ativos que estão sendo negociados, pois provoca a baixa nos preços. Por conseqüência, outros bancos detentores dos mesmos ativos são também atingidos, constituindo um cenário de incerteza que pode induzir os depositantes a sacar os recursos e gerar a desconfiança no sistema.

\subsubsection{Modelos de “corrida bancária” e ciclos de negócios}

Na mesma linha, mas sob diferente motivação, as corridas bancárias são causadas pela veiculação de informações sobre a viabilidade dos investimentos de longo prazo, tais como os indicadores de ciclos de negócios.

Gorton (1988) demonstrou que as cinco piores recessões ocorridas nos Estados Unidos, medidas pela mudança na produção de aço, foram acompanhadas de pânicos no sistema bancário $^{34}$. Usando o passivo das empresas quebradas como indicador, o autor descobriu que

34. Tabela de Gorton (1988, Tabela 1, p.233) relacionando a redução na produção de aço (“Pig Iron") com a ocorrência de crises bancárias. 
as crises são eventos sistemáticos, pois quando o indicador atinge determinado ponto, elas emergem. A suposição final do estudo é que as crises bancárias não ocorrem de forma aleatória e estão relacionadas aos movimentos cíclicos da economia.

Influenciados pelos trabalhos de Diamond e Dybvig (1983) e Gorton (1988), Allen e Gale (1998) também construíram um modelo no qual as crises financeiras são relacionadas aos ciclos de negócios. A essência do problema é a redução no valor dos ativos financeiros dos bancos, em face da redução na atividade econômica. Frente a isso, surgem as dificuldades em honrar os compromissos assumidos com os depositantes, tanto em liquidez como na taxa de retorno, repetindo-se a possibilidade de saques generalizados e o surgimento da crise bancária.

O principal objetivo dos autores foi analisar as propriedades do modelo e entender o papel do banco central em situações de pânico. Argumentam que a intervenção do banco central somente é justificada quando há possibilidade de ruptura no funcionamento do mercado, sendo considerada apropriada quando pode evitar custos desnecessários de uma crise. Concluíram que a "corrida bancária" é uma inevitável conseqüência, dada a forma como os depósitos são contratados e a incerteza agregada sobre o retorno dos ativos. Enfim, mostraram que a possibilidade de crises serve como eficiente limitador de ações dos agentes em diversas circunstâncias e induz o compartilhamento de riscos.

Ao empregar outras variáveis explanatórias, Jacklin e Bhattacharya (1988) apresentaram modelos baseados na informação, os quais utilizaram o conceito da incerteza agregada para explicar o risco cíclico dos negócios. Com base na percepção de sinais que indiquem retornos menores do que os esperados para os investimentos feitos pelos bancos, os depositantes tendem a sacar os seus recursos antecipadamente. A sucessão de saques aumenta a incerteza e cria as condições para a "corrida bancária".

Ainda, De Bandt (1995), ao estender o modelo de Jacklin e Bhattacharya (1988) a um conjunto de bancos, considerou a incerteza agregada, originada pela informação, como um choque idiossincrático que se propaga e afeta o retorno dos ativos de forma generalizada. A premissa é que as informações sobre dificuldades na obtenção de retornos de um banco específico levam os depositantes a revisar as expectativas de retorno dos depósitos em outros bancos, criando condições para uma "corrida bancária". 


\subsubsection{Modelos baseados no mercado interbancário}

Com o direcionamento voltado para o mercado interbancário, Rochet e Tirole (1996) apresentaram um modelo no qual o monitoramento pelos pares resolve o problema de "moral hazard" entre os depositantes e os banqueiros, mormente introduza maior risco de contágio.

Os autores mostram que, para quaisquer dois bancos, a probabilidade de um ser liquidado aumenta com a intensidade do choque de liquidez percebido pelo outro. Ressaltam, assim, o papel do sistema de pagamentos na obtenção de um setor bancário com menor risco sistêmico, na medida em que pode propiciar melhor gerenciamento da liquidez, identificar responsabilidades individuais e ainda detectar situações de insolvência tempestivamente.

Em outro estudo, Huang e Xu (2000) relatam a ocorrência de crises sistêmicas como uma conseqüência da seleção adversa presente na estrutura de financiamento e no mercado interbancário. A seleção adversa caracteriza-se pela aceitação de devedores com base em parâmetros de concessão, tais como taxa de juros, exigência de garantia e montante do financiamento, proporcionalmente vantajosos àqueles que apresentam perfis positivamente correlacionados com o risco de inadimplência.

A presunção do modelo é que um choque de liquidez pode trazer dificuldades diferenciadas aos bancos, não percebidas pelos participantes. A falta de distinção entre os bancos com problemas temporários de liquidez e os insolventes torna o custo de captação igual para todos. Nesse contexto, os bancos solventes subsidiam implicitamente a captação dos insolventes. No momento em que o custo de captação for superior ao custo de liquidação antecipada dos ativos existentes nas carteiras dos bancos solventes, haverá liquidações de ativos.

A saída dos bancos solventes do mercado provoca o aumento do custo de captação para aqueles remanescentes, alimentando o ciclo vicioso, até o limite de inviabilizar a continuidade das operações no mercado interbancário (DATZ, 2002, p.17). A solução está em tornar o mercado mais transparente. À medida que as informações possam segregar bancos solventes de insolventes, os problemas podem ser circunscritos aos bancos insolventes.

Adicionalmente, compararam a possibilidade de crise no mercado monetário, em face do financiamento a um banco problemático ser realizado por um ou vários bancos. A conclusão é que, quando há vários bancos financiando, o sistema é mais estável, porque o 
comprometimento compartilhado gera um equilíbrio no qual o banco insolvente não pode contaminar os bancos solventes.

\subsubsection{Modelos baseados no "efeito contágio"}

No que tange à literatura sobre o "efeito contágio", Chen (1999) elaborou um modelo conjugando-o à "corrida bancária" e ao "efeito manada". A principal contribuição do estudo é apresentar como a falência de poucos bancos pode contaminar todo o mercado, atingindo inclusive instituições com boa situação econômico-financeira.

O pressuposto é que a falência de um determinado banco provoque reações nos correntistas de outros. Caso os depositantes sem informações privilegiadas corram para sacar seus recursos, os correntistas com melhores informações serão compelidos a tomar a mesma atitude. Portanto, nesse modelo, uma crise sistêmica tem origem em um "ruído", compreendido como a falência de outra instituição, que dissemina a perda de credibilidade a todos os agentes. Como solução, Chen propõe um mecanismo que garanta os depósitos e evite a adoção de decisões precipitadas pelos depositantes, disciplinando o mercado e aumentando a eficiência do sistema financeiro.

O modelo de contágio de Allen e Gale (2000) também enfoca o papel do mercado interbancário, não pelo monitoramento dos pares, mas sim pelas exposições dos bancos e pelas ligações entre diferentes regiões, representado pela correlação de necessidades de liquidez dos respectivos depositantes.

Os autores assumem que cada uma das quatro regiões que compõem a amostra do estudo pode ser caracterizada por um banco, captando depósitos pulverizados no instante inicial, emprestando ou captando no mercado interbancário e investindo em projetos de curto e longo prazo sem risco. Nesse cenário, em uma estrutura circular de empréstimos, de "A" para "B", de "B" para "C", de "C" para "D" e desse para "A", caso a necessidade de liquidez seja coincidente e ocorra uma dificuldade inesperada, todos os bancos estão suscetíveis a problemas de liquidez e, talvez, à insolvência. No momento em que um determinado banco ou região está em crise, os créditos existentes servem de dutos para disseminar a crise em outras regiões. 


\subsubsection{Modelo baseado em preços de mercado}

Direcionado para a realidade brasileira, Tabak e Staub (2002) estenderam a utilização de modelos empregados na avaliação da probabilidade de falência em instituições financeiras, desenvolvidos com a utilização do Capital Asset Pricing Model (CAPM) e do Asset Pricing Theory (APT), e construíram um índice de estabilidade a todo o sistema bancário.

Os autores alicerçaram o desenvolvimento do modelo no APT, utilizando variáveis representativas da produção industrial, taxa de inflação, taxa de juros, risco país ${ }^{35}$, índice de mercado $^{36}$, risco de crédito $^{37}$, e o preço de fechamento da ação de quatro bancos grandes. Os testes foram realizados tanto para os bancos individualmente como para todos os bancos que negociam ações na Bolsa de Valores de São Paulo.

As variáveis relevantes estatisticamente são relacionadas com a taxa de juros, índice de mercado e risco país. A conclusão sugere que os preços de mercado são úteis na avaliação do risco sistêmico em algumas situações.

\subsubsection{Estudos empíricos ou indutivos}

No universo dos estudos de natureza indutiva, caracterizados como empíricos, há o objetivo comum de verificar quais são as variáveis ou indicadores que apresentam maior importância na explicação das crises.

Complementarmente, o interesse é conhecer os aspectos metodológicos, no tocante à composição da amostra, à definição dos períodos e à aplicação das técnicas estatísticas, e os resultados obtidos, com vistas ao delineamento da pesquisa.

Para tanto, são apresentados os trabalhos mais estreitamente relacionados aos objetivos do estudo.

35. Composta por duas variáveis, C-BOND e PSBR, calculadas respectivamente pelo "spread" entre o C-Bond e o título do tesouro americano, e pela relação entre as necessidades de financiamento do setor público e o PIB.

36. Calculado pela regressão da diferença entre o Ibovespa e o certificado de depósito interbancário (variável dependente) contra as demais variáveis independentes.

37. Calculado pela diferença entre a taxa de juros cobrada sobre o capital de giro e a taxa de juros paga ao certificado de depósito interbancário (CDI). 


\subsubsection{Estudos com utilização de técnicas de análise multivariada}

Os estudos que buscam demonstrar a probabilidade de ocorrência de crises e identificar as variáveis mais relevantes usualmente aplicam as técnicas estatísticas conhecidas como análise de regressão logística (LOGIT), análise de regressão probito (PROBIT) e análise discriminante linear (ADL).

O estudo de Fontaine (2005) aplica LOGIT em uma amostra de 37 países, sendo 21 desenvolvidos e 16 emergentes. As variáveis selecionadas, determinadas pela disponibilidade dos dados entre 1960 e 2001, contemplam as reservas internacionais, sem o valor do ouro, o valor do M2, o saldo em conta corrente, a posição fiscal orçamentária (déficit ou superávit), o índice de preços ao consumidor, os investimentos estrangeiros diretos, o volume de crédito doméstico total, os créditos ao setor privado, a taxa de desemprego e o valor do PIB.

Em adição, foram introduzidas duas variáveis, sendo uma política para verificar a interferência política e outra para identificar a ocorrência de crises em países vizinhos ("efeito contágio").

Para o período de até um ano antes da crise, incluindo a variável "dummy" interferência política, os seguintes indicadores apresentaram significância no modelo:

a) o saldo em conta corrente em relação ao PIB;

b) a variação no crédito doméstico total;

c) a posição fiscal orçamentária em relação ao PIB;

d) a taxa de inflação; e

e) a variação no M2.

O estudo conclui que os países mais suscetíveis a crises são aqueles que relaxam na condução da política monetária, com tendência a perder reservas e elevar a inflação.

Da mesma forma, Berg e Pattillo (1999b) testaram as mesmas variáveis do estudo de Kaminsky, Lizondo e Reinhart (1998) em um modelo PROBIT bivariado ${ }^{38}$. As variáveis que excedem os padrões quando as crises se aproximam foram:

38. Os modelos "logito" e "probito" podem ser na forma bivariada ou multivariada, dependendo da quantidade de variáveis dependentes usadas no modelo (duas ou mais). 
a) a variação na taxa de câmbio;

b) a variação no saldo em conta corrente;

c) a variação nas reservas internacionais;

d) a variação nas exportações; e

e) a relação e a variação entre os saldos do M2 e das reservas internacionais.

A conclusão apresenta que a utilização dos modelos ajudaria na previsão da crise financeira ocorrida no sudeste asiático em 1997, com superioridade do modelo PROBIT.

Em outro estudo, Demirgüç-Kunt e Detragiache (1997) estudaram as determinantes econômicas e estruturais das crises bancárias de países em desenvolvimento e industrializados, entre 1980 e 1994. Com o emprego de um modelo LOGIT estimaram a ocorrência de crises utilizando variáveis econômicas como PIB, taxa de juros, inflação, crédito doméstico ao setor privado e situação líquida do setor bancário. Além dessas, utilizou variáveis indicativas da existência de seguro depósito e da força da regulamentação institucional ("law and order index").

As variáveis com maior significância foram:

a) a variação no PIB;

b) a variação na taxa de juros; e

c) a variação na inflação.

Os autores identificaram que as crises tendem a eclodir em ambientes macroeconômicos frágeis, caracterizados por baixo crescimento do PIB e inflação elevada. Igualmente, as taxas de juros altas são tipicamente associadas com problemas no setor bancário, assim como as fugas repentinas de capital e a elevada participação do crédito em relação ao PIB. Por outro lado, o comportamento da taxa de câmbio não apresentou efeito sobre a probabilidade de crise no setor bancário, assim como o déficit ou superávit fiscal.

Como exceção à maioria dos trabalhos, González-Hermosillo (1999), utilizando variáveis contábeis juntamente com variáveis econômicas, investigou episódios de crises bancárias em diferentes regiões dos Estados Unidos e em dois países latino-americanos, México e Colômbia. Verificou que os bancos em situação econômico-financeira satisfatória apresentam 
características diferentes daqueles em situação insatisfatória. Os indicadores mais relevantes, que apresentam rápida deterioração antes das crises, são:

a) os créditos vencidos em relação ao total de créditos; e

b) o capital em relação ao total de ativos.

Prioritariamente, o perecimento na qualidade dos créditos mostrou ser melhor indicador de falência do que a redução no capital.

Em termos de aplicação institucional dos modelos estatísticos, o IMF tem usado um modelo PROBIT para estimar a probabilidade de crises sistêmicas em países (EDISON, 2000, p. 35). Os modelos de previsão de insolvência são vistos como insumos no processo de avaliação implementado pelo organismo. O modelo do IMF é resultante dos influentes estudos de Kaminsky, Lizondo e Reinhart (1998) e Berg e Pattillo (1999a,b), sendo que a adaptação dos modelos é realizada pelo Developing Country Studies Division (BERG; BORENSZTEIN; PATTILLO, 2004).

Igualmente, o Deutsche Bundesbank (1999, p.22) tem utilizado um modelo LOGIT para mensurar o risco sistêmico, com as seguintes variáveis:

a) variação na taxa de câmbio;

b) variação na taxa de juros do país em relação à taxa de juros americana;

c) variação nas exportações;

d) variação no volume de crédito doméstico total;

e) variação na paridade da moeda local em relação ao dólar americano, descontada a taxa de inflação interna;

f) variação no saldo em conta corrente; e

g) relação entre as reservas internacionais e o M2.

Recentemente, outras instituições como o Federal Reserve System dos Estados Unidos (KAMIN; SCHINDLER; SAMUEL, 2001) e o Banco Central Europeu (BUSSIERE; FRATZSCHER, 2002) têm envidado esforços para desenvolver modelos de previsão de insolvência. 
$\mathrm{Na}$ mesma linha, instituições privadas como o Goldman Sachs (ADES; MASIH; TENENGAUZER, 1998), o Credit Suisse First Boston (ROY; TUDELA, 2001) e o Deutsche Bank (GARBER; LUMSDAINE; VAN DER LEIJ, 2000) criaram modelos de previsão chamados de GS-Watch, Emerging Markets Risk Indicator (EMRI) e Deutsche Bank Alarm Clock(DBAC), respectivamente.

Com o emprego da análise discriminante linear, Burkart e Coudert (2002) identificaram funções lineares específicas para classificar os países da América Latina e do Sudeste Asiático, de acordo com a suscetibilidade à crise, nos períodos de um, dois, três e quatro trimestres antes da crise.

As variáveis mais significativas na equação de regressão para a América Latina são:
a) as reservas internacionais em relação ao $\mathrm{M} 2$;
b) as reservas internacionais em relação à dívida externa total;
c) as reservas internacionais em relação às importações;
d) o descolamento da taxa de câmbio real à vista do valor negociado no mercado futuro; e
e) a variação na inflação.

$\mathrm{Na}$ equação de regressão para o Sudeste Asiático, há pouca diferença entre as variáveis significativas, sendo as seguintes:
a) as reservas internacionais em relação ao $\mathrm{M} 2$;
b) a dívida externa de curto-prazo em relação à dívida externa total;
c) o descolamento da taxa de câmbio real à vista do valor negociado no mercado futuro;
d) a variação no volume de crédito doméstico total; e
e) o volume de exportações e importações em relação ao PIB.

\subsubsection{Estudos com utilização da técnica “extração de sinais"}

Alternativamente às técnicas estatísticas de análise multivariada, o teste de extração de sinais é bastante difundido nos estudos sobre crises financeiras. Salienta-se entre eles o estudo de Kaminsky, Lizondo e Reinhart (1998), que avalia a capacidade de diversas variáveis em sinalizar a proximidade de uma crise monetária. Compreende o acompanhamento de variáveis 
econômicas da situação normal ao momento que antecede a crise. O desvio de variáveis, acima ou abaixo de padrões predeterminados, é considerado sinal de crise. O histórico de sinalizações dos indicadores permite avaliar a capacidade individual e combinada em prever crises.

A técnica de extração de sinais é um método não-paramétrico que consiste em monitorar diversos indicadores que tendem a exibir um comportamento anormal no período precedente à crise. Quando um indicador excede o limite determinado, como dois ou três desvios-padrão, no período de acompanhamento estipulado, interpreta-se como um sinal de proximidade da crise. A simplicidade permite considerá-la como uma extensão das metodologias que comparam o comportamento de variáveis em períodos que precedem as crises com algum grupo de controle.

Além de avaliar a desempenho de cada indicador com base na quantidade de sinais corretos emitidos no período de 24 meses que antecede a crise, verifica a antecedência e a persistência do sinal até a crise.

A contribuição da técnica é oferecer um conjunto de indicadores sinalizadores de crises, ordenados pela capacidade de previsão, facilitando o entendimento dos acontecimentos até o momento das crises.

Os indicadores que apresentaram a maior quantidade, antecedência e persistência na emissão de sinais, no estudo de Kaminsky, Lizondo e Reinhart (1998), estão relacionados com as seguintes variáveis:
a) variação na taxa de câmbio;
b) variação no volume de crédito doméstico total;
c) variação nas reservas internacionais;
d) variação nas exportações; e
e) variação no PIB.

Em estudo similar, utilizando a mesma técnica de "extração de sinais", Edison (2000) confirma a evidência de existir características comuns quando ocorre o ataque contra a 
moeda. Entretanto, em face das diferenças entre as variáveis identificadas, o estudo sugere que a abordagem deve ser moldada ao país ou à região.

Como resultado, as variáveis mais significativas para a América Latina são:

a) as variações nas exportações, com sinalização correta em 93\% das crises;

b) a variação na dívida externa de curto prazo em relação à variação nas reservas internacionais, com $88 \%$ de acerto; e

c) a variação nas reservas internacionais, com $79 \%$ de acerto.

Para o Sudeste Asiático, as variáveis mais significativas são:

a) a variação na dívida externa de curto prazo em relação à variação nas reservas internacionais, com sinalização em 100\% das crises;

b) a variação no multiplicador do $\mathrm{M} 2$, com acerto em $83 \%$ das crises; e

c) a variação no crédito doméstico total em relação ao PIB, com $63 \%$ de acerto.

$\mathrm{Na}$ avaliação global, os indicadores representativos das variações nas exportações, na produção industrial, no crédito doméstico total em relação ao PIB e nas reservas internacionais participam com percentual superior a $60 \%$ na sinalização de crises.

\subsubsection{Variáveis e indicadores relevantes em outros estudos}

$\mathrm{Na}$ fundamentação teórica do estudo sobre a utilização da técnica de extração de sinais, Kaminsky, Lizondo e Reinhart (1998) realizaram a análise de 28 estudos relacionados à previsão de crises financeiras ${ }^{39}$, os quais examinam um conjunto de experiências de crises, tanto de países industrializados como em desenvolvimento, ocorridos entre 1950 e 2000.

39. Os trabalhos analisados por Kaminsky, Lizondo e Reinhart (1997) foram Bilson (1979), Blanco e Garber (1986), Calvo e Mendoza (1996), Collins (1995), Cumby e Van Wijnbergen (1989), Dornbusch, Goldfajn e Valdés (1995), Edin e Vredin (1993), Edwards (1989), Edwards e Montiel (1989), Edwards e Santaella (1993), Eichengreen, Rose e Wyplosz (1995), Flood e Marion (1995), Frankel e Rose (1996), Goldfajn e Valdés (1998), Goldstein (1996), Humberto, Julio e Herrera (1991), Kamin (1988), Kaminsky e Reinhart (1996), Klein e Marion (1994), Krugman (1996), Milesi-Ferretti e Razin (1996 e1998), Moreno (1995), Ötker e Pazarbasioglu (1996), Sachs, Tornell e Velasco (1995). 
Mais da metade utiliza dados mensais e estão concentrados em períodos que antecedem as crises, com previsão entre um e dois anos. Como resultado, identificaram um conjunto de indicadores, dentre os 105 testados, que aparece freqüentemente com maior relevância estatística.

Os indicadores apontados significativos estatisticamente na maior quantidade de estudos são:

a) a variação na taxa de câmbio, em doze estudos;

b) a variação nas reservas internacionais, em onze estudos;

c) as variações no produto interno bruto, no crédito e na taxa de inflação, em cinco estudos cada um; e

d) a relação entre o M2 e as reservas internacionais em três estudos.

Finalmente, a pesquisa de Caprio e Klingebiel (2003) descrevendo 117 situações de elevado risco sistêmico ou de crise bancária em 93 países, a partir do final dos anos de 1970, ressalta como característica das crises o volume de créditos classificados como de difícil liquidação, a quantidade de bancos reestruturados mediante aquisição, fusão ou fechamento, assim como o respectivo custo fiscal em relação ao PIB.

Essa maneira de demonstrar os efeitos das crises bancárias evidencia a importância da informação contábil, especialmente no que tange à qualidade das operações de crédito e à capacidade do patrimônio líquido na absorção dos prejuízos decorrentes.

\subsubsection{Identificação das crises}

Um dos pontos essenciais para obtenção de resultados satisfatórios na identificação de variáveis relevantes à previsão de crises é a correta identificação do período da crise. Falhas no procedimento podem culminar em conclusões enganosas.

A identificação das crises monetárias é facilitada pela disponibilidade de dados econômicos periódicos sobre variáveis determinantes à sinalização das crises. Os dados relativos às variáveis reservas internacionais, taxa de câmbio, taxa de juros, produto nacional bruto, entre outras, são disponíveis para quase todos os países em órgãos como o IMF e o BIRD. 
Nesse sentido, para aferição da ocorrência de uma crise monetária, alguns estudos consideram exclusivamente a desvalorização cambial da moeda do país, enquanto outros incluem também o aumento das taxas de juros ou a perda de reservas internacionais.

O índice de "pressão do mercado de câmbio"40, elaborado por Kaminsky e Reinhart (1999, p.498), na linha do indicador desenvolvido por Eichengreen, Rose e Wyplosz (1994, p. 15; 1996, p. 21) ${ }^{41}$, é um dos instrumentos freqüentemente utilizado nos estudos. A equação para determinar a ocorrência de crise é:

$I=\frac{\Delta e}{e}-\frac{\sigma e}{\sigma R} * \frac{\Delta R}{R}$

onde $\Delta e$ é a variação da taxa de câmbio, $e$ é a taxa de câmbio, $\sigma e$ é o desvio-padrão da taxa de câmbio, $\Delta R$ é a variação no saldo das reservas internacionais, $R$ é o saldo das reservas internacionais e $\sigma R$ é o desvio-padrão da variação no saldo das reservas internacionais.

Pela equação, quanto maior a variação positiva na taxa de câmbio (aumento) e maior a variação negativa no saldo de reservas (diminuição), maior será o índice de pressão do mercado de câmbio. A divisão dos desvios-padrão das variáveis tem por finalidade eliminar a variância de uma variável contida na outra.

Outro indicador, com resultados muito próximos ao anterior, é o de Milesi-Ferreti e Razin (1998), conceitualmente semelhante ao de Frankel e Rose $(1996)^{42}$. O indicador considera crise quando as seguintes condições são verificadas conjuntamente:

a) A desvalorização na taxa de câmbio do período vigente é superior a 15\%;

b) a desvalorização corresponde, no mínimo, a 110\% da depreciação do período anterior; e

c) a variação na desvalorização do período anterior é inferior a 10\%.

De forma que atenda a seguinte equação:

40. Tradução de "exchange market pressure".

41. O indicador aumenta quando as reservas internacionais diminuem, as taxas de juros aumentam e a taxa de câmbio deprecia.

42. Frankel e Rose (1996, p.3) definem crise como a depreciação nominal da taxa de câmbio superior a 25\%, tendo essa depreciação excedido a variação do ano anterior em pelo menos $10 \%$. 
Ind $_{M F R}=1$ se $E>15 \%$ e $E>\left(E_{-1}+10 \%\right)$ e $E_{-1}<10 \%$.

Ind ${ }_{M F R}=0$, caso contrário.

onde $E$ é a depreciação da taxa de câmbio do ano vigente, e $E_{-1}$ é a depreciação da taxa de câmbio do ano anterior.

De uma forma mais simples, Fontaine (2005, p.16) definiu a ocorrência de crise quando o regime cambial é alterado e/ou a queda no saldo das reservas internacionais é superior a 30\% no período de um ano.

Diferentemente, os dados de variáveis contábeis das instituições financeiras, como os componentes do capital, as provisões e os resultados, mesmo agregados, são comparativamente mais difíceis de ser obtidos.

Por esse motivo, a identificação das crises bancárias tem sido realizada pela constatação de corridas bancárias, processos generalizados de fechamento ou de reestruturação de instituições, e a adoção de programas governamentais ou internacionais de assistência financeira. As ocorrências de crises bancárias procuram ser comprovadas pela veiculação de notícias e pelos estudos realizados a respeito (GOLDSTEIN; KAMINSKY; REINHART, 2000, p.19).

Na mesma linha, mas utilizando informações contábeis, Caprio e Klingebiel (2003) definiram como critério para identificação de crises bancárias o significativo ou o completo perecimento do capital.

\subsubsection{Conclusão dos estudos}

Em síntese, a comparação dos estudos não permite extrair uma resposta conclusiva sobre o melhor modelo para avaliar ou prever crises, pois há diferenças significativas na mensuração e na periodicidade das variáveis testadas, assim como na técnica de estimação. De qualquer forma, há um grupo de variáveis e indicadores econômicos que se destaca na maior parte dos estudos. 
A sugestão é priorizar os modelos que maximizem as porcentagens de previsões corretas para crises e não-crises, lembrando que, apesar de ser menos custoso agir preventivamente, o número de alarmes falsos é muito superior ao número de crises não identificadas.

\subsection{Principais crises que afetaram o setor bancário}

No sentido de compreender o contexto e as características que antecedem as crises financeiras, o resumo de algumas análises elaboradas pelos organismos internacionais, como o IMF e o BIRD, e pelos próprios bancos centrais dos países onde ocorreram as crises é apresentado a seguir.

\subsubsection{Argentina}

A Argentina sofreu duas crises bancárias, uma iniciada em março de 1995 e outra em janeiro de 2002.

A primeira seguiu a crise mexicana, no movimento denominado "efeito tequila", sendo marcadamente provocada por fatores externos. Conforme Caprio et al. (1998), a Argentina, naquele período, apresentava fundamentos macroeconômicos sólidos. O déficit em conta corrente estava em torno de $4 \%$ do produto interno bruto (PIB), a dívida externa estava estruturada em longo prazo, as reservas internacionais eram relativamente altas, havia estabilidade política e econômica e um conjunto de reformas estruturais, como a privatização de empresas públicas, foi satisfatoriamente implementado. Enfim, não havia vulnerabilidade aparente capaz de provocar uma crise.

Entretanto, entre dezembro de 1994 e março de 1995, o sistema bancário perdeu em torno de $16 \%$ dos depósitos e o saldo das reservas internacionais reduziu em um terço, no valor equivalente a cinco bilhões de dólares, de acordo com as estatísticas do IMF (2003).

A crise começou nos bancos de atacado, que estavam altamente aplicados em ativos financeiros de curto prazo, inclusive no financiamento a bancos no mercado interbancário. Repentinamente, saques vultosos nesses bancos fizeram com que grande volume de ativos 
fosse vendido conjuntamente. A redução nos preços dos títulos gerou problemas de liquidez e os juros no interbancário subiram radicalmente.

Alguns bancos com problemas estruturais, com créditos vencidos na ordem de $40 \%$ do total da carteira (CAPRIO et al., 1998, p.38), notadamente controlados pelo setor público estadual (províncias), perderam a fonte de financiamento para "rolar" o endividamento de curto prazo, tornando-se insolventes.

O pânico causado nos investidores, considerados experientes e sensíveis aos primeiros sinais de anormalidade emitidos, precipitou os saques em todo o sistema bancário, com vistas a converter a moeda nacional em moeda estrangeira e a aplicação em bancos no exterior. Nesse contexto, o Banco Central da Argentina foi obrigado a estabelecer garantias aos depósitos e prover assistência de liquidez aos bancos, à custa das reservas internacionais.

Em determinado momento, o nível das reservas internacionais aproximou-se perigosamente do volume dos meios de pagamento, sendo que o plano de conversibilidade garantia a troca "ao par" da moeda nacional pela moeda estrangeira. A crise apenas arrefeceu quando as autoridades competentes anunciaram medidas drásticas de controle dos gastos e obtiveram assistência financeira externa (IMF, 2001b).

Como conseqüência, houve a reestruturação do setor financeiro até o final de 1997, quando 63 bancos dos 205 bancos existentes no período pré-crise foram incorporados, fundidos ou fechados.

A segunda crise, reconhecidamente mais severa, por ter origem na crise monetária que levou à liberalização da taxa de câmbio e à desvalorização da moeda, iniciou em dezembro de 1999.

Para Levy-Yeyati, Peria e Schmukler (2004), a Argentina foi vítima de circunstâncias externas causadoras do crescimento da dívida em moeda estrangeira, tais como a desvalorização da moeda brasileira em janeiro de 1999, a alta taxa de juros praticada no mercado internacional e a sobrevalorização do dólar frente às demais moedas. 
Mesmo assim, o setor bancário apresentava situação estável, com nível médio de capital em 20\%, mensurado na forma estabelecida pelo Acordo de Basiléia, superior ao índice médio de 14\% do Uruguai, 13\% do Chile, Peru e México, e 11\% da Colômbia.

A deterioração econômica intensificou-se em 2001 e a dúvida sobre a manutenção da conversibilidade do peso argentino em dólar, na paridade de um para um, era cada vez maior. Contribuíram para incrementar a incerteza as alterações no comando do banco central e a concessão de poderes especiais para injetar liquidez na economia, com abandono da regra sob a qual pairava a conversibilidade, de emissão monetária ancorada na quantidade de reservas em moeda estrangeira.

Ao tempo que mantinham o crescimento da dívida, as autoridades adiaram a crise pela absorção de liquidez dos bancos via colocação de títulos públicos, expondo o sistema bancário cada vez mais ao risco de inadimplemento do governo.

Frente a essas incertezas, as fontes de financiamento desapareceram e aumentou a probabilidade de emissão de moeda sem lastro, bem como o risco do não cumprimento da conversibilidade. Ao final do ano de 2001, a "corrida bancária" foi deflagrada, com redução de $50 \%$ nos depósitos a prazo. O risco-país, aferido com base no índice $\mathrm{EMBI}^{43}$, saltou abruptamente de 703 para 4.385 pontos.

A precipitação trouxe o descontrole à economia e a ruptura do sistema de pagamentos, os quais tentaram ser estancados pela implantação de limites para saques em conta-corrente ("corralito").

Ao mesmo tempo, o governo não honrou o pagamento dos títulos, abandonou o compromisso de conversibilidade da moeda, estendeu os prazos para resgate dos depósitos e implantou um regime cambial de taxa flutuante, com $40 \%$ de desvalorização imediata. Como agravante, havia a instabilidade política provocada pela posse e abdicação de vários presidentes.

A estabilidade na Argentina somente foi conseguida após a renegociação da dívida com os credores externos e a obtenção de ajuda financeira do IMF.

43. Emerging Market Bond Index. Índice calculado pela diferença entre o “yield” pago pelo título soberano de um país emergente e o título emitido pelo governo americano (US Treasury Bond). 


\subsubsection{Brasil}

O aumento do risco sistêmico e a eminência de uma crise financeira estiveram presentes em dois momentos recentes e distintos da história brasileira.

O primeiro é caracterizado por problemas em instituições financeiras bancárias, acumulados ao longo de décadas, que vieram à tona com a implementação do Plano Real em 1994, marco inicial do processo de mudanças no sistema financeiro.

Os anos de inflação elevada, superior a 1.000\% ao ano, em 1989, 1990, 1992, 1993 e 1994, propiciaram receitas de "floating" suficientes para cobrir os custos operacionais e os problemas de inadimplência. Sob essas condições de lucros fáceis, o setor expandiu-se consideravelmente, atingindo a quantidade de 244 bancos comerciais em dezembro de 1995 (MARQUES, 2003, p.182).

A Tabela 5 relaciona a queda da inflação com a redução abrupta da participação do sistema financeiro no produto nacional bruto. De acordo com Barros e Mansueto (1997), os bancos perderam cerca de dezenove bilhões de reais em receitas em virtude da estabilização de preços.

Tabela 5 - A receita inflacionária dos bancos

\begin{tabular}{|r|c|r|}
\hline Ano & Receita dos bancos / PIB & \multicolumn{1}{|c|}{ Inflação em \%(IPC) } \\
\hline 1990 & $4,0 \%$ & $1.997,16$ \\
\hline 1991 & $3,9 \%$ & 447,45 \\
\hline 1992 & $4,0 \%$ & $1.117,31$ \\
\hline 1993 & $4,2 \%$ & $2.287,34$ \\
\hline 1994 & $2,0 \%$ & $1.216,33$ \\
\hline 1995 & $0,0 \%$ & 23,05 \\
\hline
\end{tabular}

FONTE: IBGE/ANDIMA, 1997, apud MAIA, 1999, p.108.

Tamanha perda obrigou os bancos a realizar mudanças significativas, com vistas à adaptação ao ambiente de inflação baixa, estabilidade econômica e política monetária rígida. A alternativa para obtenção de receitas passou a ser a concessão de crédito, que apresentou o rápido crescimento de 60\% no primeiro ano do Plano Real (MAIA, 1999, p.108).

Entretanto, em face do receio do recrudescimento da inflação, as autoridades monetárias adotaram medidas restritivas ao crédito, entre as quais se salienta a elevação da taxa de recolhimento compulsório sobre os depósitos à vista para 100\%. 
Com a redução da atividade econômica em 1995, resultante da elevação das taxas de juros a $40 \%$ ao ano, em resposta à crise mexicana, ocorreu o crescimento da inadimplência. Nessa situação de queda da receita inflacionária e aumento da inadimplência, as ineficiências emergiram, evidenciando a inviabilidade econômico-financeira de algumas instituições. Além disso, o aumento da competitividade no setor bancário, com a entrada de grandes bancos estrangeiros, dificultou ainda mais a situação dos bancos com problemas.

Frente à quebra de dois grandes bancos privados, Econômico e Nacional, a desconfiança sobre o setor bancário aumentou, com ocorrência de saques vultosos em bancos considerados frágeis.

Para reduzir o perigo de uma "corrida bancária" generalizada, houve a criação do FGC (Fundo Garantidor de Crédito), em agosto de 1995, e do PROER (Programa de Estímulo à Reestruturação e ao Fortalecimento do Sistema Financeiro Nacional), em novembro de 1995.

O programa buscou dar estabilidade ao sistema e garantias aos pequenos depositantes e credores dos bancos. Diversos processos de aquisição e fusão ocorreram sob o amparo do PROER, os quais representaram gastos na ordem de vinte bilhões de reais, no período entre novembro de 1995 e junho de 1997 (MAIA, 1999, p.115).

Ao mesmo tempo em que ocorria o saneamento do sistema financeiro, com a exclusão das instituições problemáticas, novas regulamentações foram instituídas com o objetivo de reduzir os riscos e garantir o funcionamento normal do sistema dentro de padrões internacionais de supervisão bancária.

O segundo momento é marcado pela crise monetária ocorrida em janeiro de 1999, que culminou com o fim do regime de câmbio fixo até então vigente. A pressão sobre o regime iniciou-se em 1997, quando diversos setores assumiram dívidas no exterior em virtude das baixas taxas de juros e da percepção de que o risco estava limitado pelo regime cambial.

O Brasil adotava um regime de câmbio fixo determinante ao controle da inflação e ao sucesso do plano de estabilização econômica iniciado em 1994. No mercado internacional, havia liquidez de recursos e relativa estabilidade. Esses aspectos levaram o setor empresarial e bancário a optar por captações em moeda estrangeira. O descasamento entre ativos e passivos 
em moeda estrangeira no sistema bancário aumentava gradativamente, sempre com maior posição líquida passiva.

Com a explosão da crise Asiática em outubro de 1997, houve acentuada demanda por operações para proteger a exposição passiva (hedge). Para atender a demanda e também garantir a rolagem da dívida mobiliária, o governo emitiu títulos indexados à variação cambial $\left(\mathrm{NTN}-\mathrm{D}\right.$ e $\left.\mathrm{NBCE}^{44}\right)$.

Em 1998, a pressão sobre a taxa de câmbio cresceu, advinda de falhas no cumprimento do ajuste fiscal e redução precipitada na taxa de juros, forçando nova intervenção para garantir o regime de câmbio fixo.

Os agentes econômicos, por sua vez, aproveitaram tanto para reduzir suas exposições em moeda estrangeira como para especular sobre uma futura desvalorização. Ao final de 1997, o governo emitiu o equivalente a 23 bilhões de dólares em títulos indexados ao câmbio para garantir a estabilidade da moeda. Ao final de 1998, o mercado estava com posição líquida ativa em moeda estrangeira (comprado em dólar), à custa das posições assumidas pelo BCB (Banco Central do Brasil).

Concomitantemente, a crise da Rússia agravou a situação no cenário internacional com aumento da desconfiança sobre a capacidade de pagamento dos mercados emergentes, entre eles o Brasil. Para manter os recursos no país e proteger o câmbio, a autoridade monetária brasileira dobrou a taxa de juros, passando de $19 \%$, em setembro, para $40 \%$, em novembro. $\mathrm{O}$ aumento provocou o descasamento no sistema bancário.

Novamente, para evitar problemas nos bancos, o governo emitiu títulos pós-fixados pela nova taxa, os quais foram gradualmente incorporados às carteiras das instituições. Com isso, o risco de taxa de juros, assim como de câmbio, migraram do sistema para o $\mathrm{BCB}$, e, em última instância, para o governo.

44. Títulos públicos federais emitidos pelo Tesouro Nacional (NTN-D) e Banco Central do Brasil (NBCE). 
No dia 13 de janeiro de 1999, o regime de câmbio foi alterado, com implantação de um regime de câmbio de banda flutuante para administrar a transição entre a taxa de câmbio fixa e a taxa de câmbio flutuante.

Sob medidas de proteção à moeda nacional, o sistema bancário brasileiro obteve lucros recordes no início de 1999, coincidente com a mudança de regime. Essa experiência difere radicalmente de outros países onde o sistema bancário, após o abandono de um regime de taxa de câmbio fixa, acumula prejuízos significativos e enfrenta problemas de liquidez.

Em contrapartida, o BCB amargou significativas perdas ao honrar o pagamento das posições vendidas em câmbio e também o aumento do custo da dívida mobiliária pela elevação da taxa de juros. $\mathrm{O}$ custo total da blindagem oferecida pelo autoridade monetária aos setores bancário e empresarial está registrado no prejuízo apresentado no balanço de 1999.

Além disso, faz-se importante observar que, ao final de 1997, a dívida pública representava $35 \%$ do PIB e quase $50 \%$ estava composta por títulos de renda fixa de curto prazo, pré e pós fixados. Após a pressão sobre o câmbio, não apenas o percentual da dívida em relação ao PIB subiu para $53 \%$, como também houve alteração na composição, que passou a conter $90 \%$ em títulos indexados a moeda estrangeira.

Apesar de ambos períodos configurarem situações de crise, as intervenções do governo brasileiro, de custos elevados e com repercussões econômicas, conseguiram evitar que os efeitos eclodissem e provocassem a instabilidade generalizada.

\subsubsection{Coréia do Sul, Indonésia, Tailândia, Filipinas e Malásia (Sudeste Asiático)}

A crise no Sudeste Asiático foi resultante de diversos eventos simultâneos. O marco foi a desvalorização da moeda tailandesa, o Thai Baht, em julho de 1997, seguida pelas demais moedas nos países vizinhos. A rápida retirada de capital estrangeiro, a "corrida bancária", a queda nos "ratings" e o declínio acentuado na atividade econômica de cada país, combinados com as vulnerabilidades e as fraquezas do setor financeiro, resultaram na crise generalizada em toda a região. Como agravante, a conexão da economia asiática com o sistema financeiro internacional contribuiu para disseminar a crise também em outras partes do mundo. 
Mais do que uma crise financeira, a crise asiática evidenciou a ligação entre a saúde do sistema financeiro e a estabilidade macroeconômica. A elevada alavancagem dos setores empresariais e o volume de dívidas em moeda estrangeira a curto prazo no sistema bancário, sem a devida proteção, originaram situações de alto risco.

A exposição cambial foi abastecida pela vultosa entrada de capitais estrangeiros, na forma de empréstimos diretos tomados pelos bancos e pelas corporações, equivalentes a $10 \%$ do PIB tailandês, 3,5\% do indonésio e 2,5\% do coreano, no período entre 1990 e 1996 . O incentivo ao endividamento foi marcado pela estabilidade da taxa de câmbio sobre-valorizada e também pela inexistência de regras prudenciais e limites para exposição em moedas estrangeiras.

A abrupta saída do capital internacional e o corte de crédito dos bancos estrangeiros, somados à manutenção da expansão de crédito interno, que levou à multiplicação dos meios de pagamento e ao aumento da inflação, agravou o problema. Na proporção em que a inflação aumentava, maior era a fuga dos capitais estrangeiros de curto prazo e a pressão para desvalorizar a moeda nacional.

Os principais aspectos não evidenciados nas demonstrações contábeis das instituições financeiras foram as transações entre partes relacionadas, a exposição ao risco cambial, especialmente de curto prazo, os critérios de classificação do crédito e de apropriação das rendas, as operações de "troca de chumbo" com garantias cruzadas, as informações em bases consolidadas, a concentração do crédito, as operações com instrumentos derivativos e os passivos contingentes do controlador ou do conglomerado sobre as garantias prestadas.

Tabela 6 - Estrutura do sistema financeiro em 31.12.1996.

\begin{tabular}{|l|c|c|c|c|c|}
\hline \multicolumn{1}{|c|}{ País } & $\begin{array}{c}\text { Bancos } \\
\text { Comerciais }\end{array}$ & $\begin{array}{c}\text { Bancos Rurais } \\
\text { e Cooperativas }\end{array}$ & $\begin{array}{c}\text { Outras Instituições } \\
\text { Financeiras }\end{array}$ & $\begin{array}{c}\text { Seguradoras } \\
\text { e Fundos }\end{array}$ & $\begin{array}{c}\text { Participação } \\
\text { Ativos/PIB }\end{array}$ \\
\hline Indonésia & 238 & 9200 & 252 & 502 & $90 \%$ \\
\hline Coréia & 78 & 6000 & 353 & 71 & $300 \%$ \\
\hline Malásia & 35 & $*$ & 58 & $*$ & $300 \%$ \\
\hline Filipinas & 49 & 800 & 109 & 129 & $115 \%$ \\
\hline Tailândia & 29 & 4000 & 91 & 880 & $190 \%$ \\
\hline
\end{tabular}

* Não informado

FONTE: Elaborada com base nos dados do IMF.

A Tabela 6 evidencia a alavancagem do sistema no período anterior à crise. A participação dos ativos em relação ao PIB em todos os países, com exceção da Indonésia, demonstra a 
superioridade do volume de ativos do sistema financeiro em relação ao total da produção do país, evidenciando um preocupante descasamento entre os ativos financeiros e os ativos reais.

A reestruturação do sistema financeiro foi significativa e de custo elevado. Os dados constantes da Tabela 7 permitem verificar a quantidade de bancos e outras instituições financeiras submetidas aos processos de fusão, incorporação, intervenção e fechamento, assim como o custo em relação ao PIB.

Tabela 7 - Fusões e incorporações, fechamentos e intervenções do Estado em instituição financeira

\begin{tabular}{|c|c|c|c|c|}
\hline País & Fusões/Incorporações & Fechamentos & Intervenções & Custo / PIB \\
\hline Indonésia & 4 bancos públicos $(54 \%)$ & 64 bancos $(18 \%)$ & 12 bancos $(20 \%)$ & $45 \%$ \\
\hline Coréia & $\begin{array}{l}\text { Fusão de } 11 \text { em } 4 \text { bancos } \\
(15 \%) \text {. }\end{array}$ & $\begin{array}{l}5 \text { bancos, } 17 \mathrm{BI}^{* *} \text {, e } 100 \\
\text { não-bancárias. }(15 \%)\end{array}$ & 4 bancos $(14 \%)$ & $15 \%$ \\
\hline Malásia & 15 fusões $(6 \%)$ & Não houve & $1 \mathrm{BI} * *$ e $3 \mathrm{SCFI} * *(3 \%)$ & $12 \%$ \\
\hline Filipinas & 4 bancos & 1 banco $(1 \%)$ & - & $*$ \\
\hline Tailândia & $\begin{array}{l}\text { Fusão de } 5 \text { em } 3 \text { bancos e } \\
12 \text { SCFI }^{* * *}(16 \%)\end{array}$ & $\begin{array}{|llll|}56 & \mathrm{SCFI}^{* * *} \quad(11 \%) & \text { e } & 1 \\
\text { banco }(2 \%)\end{array}$ & \begin{tabular}{|l}
$\begin{array}{l}6 \text { bancos } \\
(12 \%)\end{array}$ \\
\end{tabular} & $10 \%$ \\
\hline
\end{tabular}

O restabelecimento das economias asiáticas não está completamente terminado. As seqüelas ainda persistem, especialmente quanto à confiança no sistema bancário.

\subsubsection{México}

A crise financeira que assolou o México ao final de 1994 e durante todo o ano de 1995 foi considerada inusitada pelos analistas. Os fundamentos estavam sólidos, não havia déficit fiscal significativo nem inflação elevada, comparando-se com outros países. Os ativos mexicanos eram aceitos pelos investidores internacionais e havia entrada de capitais externos.

Repentinamente o quadro mudou e a saída abrupta de capitais não permitiu a adequação do sistema. A conseqüência foi uma profunda crise monetária e bancária, envolvendo todos os setores produtivos.

Conforme Martinez (1998), o desenvolvimento econômico e a estabilidade apresentada nos anos anteriores à crise propiciaram a entrada de capitais externos que procuravam retornos maiores. Como o México oferecia altas taxas de juros e apresentava relativa estabilidade e 
potencial de crescimento para honrar os compromissos, o país representava excelente opção de investimento.

A atratividade estava alicerçada nos efeitos das medidas adotadas em meados dos anos de 1980, como o controle fiscal, a desregulamentação do mercado e a privatização de empresas estatais. Além disso, a renegociação da dívida externa, alongando os prazos, e a implementação de significativas mudanças nas relações comerciais com vistas à inclusão na NAFTA (North American Free Trade Agreement) demonstravam a intenção do México em ser reconhecido como uma economia de mercado estável.

O resultado foi o massivo ingresso de recursos entre 1990 e 1994, na ordem de 104 bilhões de dólares, correspondente a $20 \%$ do total direcionado a todos os países emergentes no período. Esses recursos propiciaram o crescimento médio no período de $3,9 \%$ no PIB, em um contexto de baixa inflação.

Os reflexos dos recursos eram percebidos na rápida expansão da demanda agregada, no aumento dos preços das ações e imóveis, na aceleração do crescimento de ativos e passivos dos bancos e no surgimento de um significativo déficit em conta-corrente. Esse último aspecto começou a despertar a desconfiança nos investidores internacionais sobre a capacidade de manutenção do crescimento. Até quando o México conseguiria sustentar o crescimento e o pagamento de dívidas crescentes?

As razões da vulnerabilidade do país eram as seguintes:

a) crescimento excessivo do crédito bancário;

b) crescimento da dívida de curto prazo, especialmente em moeda estrangeira;

c) aumento do déficit em conta-corrente;

d) aumento nas taxas de juros internacionais;

e) ocorrência de eventos políticos, inclusive crimes; e

f) manutenção do regime de taxa de câmbio fixa.

Esse conjunto de variáveis, adicionado a um sistema financeiro fraco, caracterizado por supervisão e regulação inadequadas, levaram ao ataque especulativo. A forte pressão para 
abandonar o regime de câmbio fixo culminou na desvalorização da moeda em dezembro de 1994.

Assim que a crise emergiu, o governo implantou ajustes nas políticas monetária e fiscal, adotou o regime de câmbio flutuante, avançou nas reformas estruturais e liberalizou ainda mais o mercado. Houve a negociação de um empréstimo emergencial com o governo americano, IMF, BIRD e Banco Interamericano de Desenvolvimento (BID), assim como a suspensão do pagamento da dívida por determinado prazo, com vistas a evitar que a crise se propagasse a outros países.

Para evitar o "efeito contágio" e o descumprimento de obrigações, especialmente junto a credores internacionais, o governo garantiu a liquidez em moeda estrangeira aos bancos comerciais, capitalizou bancos, autorizou a maior participação estrangeira no controle dos bancos e renegociou dívidas de alguns devedores dos bancos. O custo estimado da crise bancária representou 14,4\% do PIB de 1997, e deve ser amortizada em 30 anos.

\subsubsection{Rússia}

Em agosto de 1998, a Rússia assumiu o centro da crise financeira que afligiu os mercados emergentes. Conforme o IMF (1998a, p.15-16), a principal causa da crise foi a perda de confiança do mercado financeiro internacional motivada pelo desequilíbrio fiscal crescente, o significativo endividamento de curto prazo e os atrasos na implementação de reformas estruturais internas.

Agravaram ainda mais a situação o declínio no preço do petróleo, a queda generalizada nos preços das ações, o aprofundamento da crise asiática, a intervenção no maior banco comercial e a sucessão de greves por melhores salários.

Os reflexos da desconfiança são verificados na sucessão de medidas adotadas, sem impactos duradouros, entre as quais se destacam:

a) A constante venda de moeda estrangeira para estabilizar o valor do rublo;

b) o aumento da taxa de juros em $150 \%$ no final de maio;

c) corte de despesas em $20 \%$ no orçamento de 1998 ; 
d) aumento das receitas via impostos, particularmente junto a grandes empresas do setor de energia; e

e) aceleração das reformas estruturais.

A adoção de políticas de ajuste mais rígidas, anunciadas em junho e julho, associadas com a assistência do IMF, BIRD e Japão, trouxeram alívios temporários. Os preços das ações subiram quase $30 \%$, as taxas dos títulos do tesouro caíram de quase $100 \%$ para $50 \%$, e o banco central conseguiu alongar a dívida em rublo, emitindo novos papéis com prazo superior a um ano.

Apesar das medidas, havia a percepção de que o governo não seria capaz de implementar medidas corretivas estruturais, haja vista a oposição do parlamento às medidas do governo. $\mathrm{A}$ falta de apoio político levou inclusive à redução da ajuda do IMF de 5,6 bilhões para 4,8 bilhões de dólares.

Além disso, problemas em diversos setores como no bancário, em face da queda no valor dos ativos, no petrolífero e no de energia, pela elevação dos impostos, dificultaram a execução dos programas planejados pelo governo.

Como resultado, as taxas oferecidas aos títulos públicos subiram e as ações caíram novamente. Os leilões de colocação de títulos de longo prazo foram cancelados em face das taxas proibitivas. A pressão sobre o rublo aumentou, obrigando o banco central a utilizar novamente as reservas para manter o valor frente ao dólar.

Em agosto, a taxa de juros média paga aos títulos girava em torno de $300 \%$, as reservas reduziram-se a cerca de quinze bilhões de dólares e muitos bancos estavam insolventes. Enfim, a Rússia encontrava-se em crise monetária e bancária, ou seja, as crises gêmeas.

A saída das autoridades foi desvalorizar o rublo, converter unilateralmente a dívida de curto prazo em longo prazo, suspender a negociação de títulos públicos no mercado doméstico, declarar a moratória de 90 dias no pagamento de obrigações em moeda estrangeira com o setor privado, aumentar o controle de capitais e tentar estabilizar o setor bancário, assumindo as obrigações com os depositantes. 
A reação do mercado foi negativa, em face da incerteza no esquema de conversão e pela moratória. Como resultado, a taxa de câmbio caiu 10\%, assim como os preços das ações, o spread dos títulos soberanos da Rússia (em dólar) aumentou de 1.000 para mais de 3.000 pontos base. A conseqüência foi o aumento da taxa de juros para $250 \%$ ao ano e a utilização de mais reservas para conter a desvalorização da moeda nacional, reduzindo o saldo a 13,5 bilhões de dólares.

A partir de 26 de agosto, o banco central suspendeu a venda de dólar e a cotação somente estabilizou em 15 rublos por dólar, bem acima do limite fixado para a banda. Em setembro, o banco central finalmente abandonou o sistema de bandas e deixou o rublo flutuar. O mercado financeiro permaneceu ilíquido e altamente volátil.

Com a dissolução do governo, e a subseqüente incerteza política, o caos estava instalado. No setor bancário, os bancos tentavam se organizar para enfrentar a escassez de liquidez e as dificuldades no sistema de pagamentos. Por outro lado, o banco central continuava atuando no cancelamento de licenças de funcionamento e impondo intervenções temporárias na administração de bancos importantes ao sistema.

A junção de fraquezas nos fundamentos econômicos com um ambiente externo desfavorável, em meio a crises; a percepção de crescente desequilíbrio no balanço de pagamentos financiado com dívidas de curto prazo; as reformas estruturais não-realizadas, pela falta de apoio político; o fraco gerenciamento das contas públicas; e a inexistência de prestação de contas e de transparência nas operações governamentais, culminaram em um déficit equivalente a $10 \%$ do PIB, configurando na maior crise financeira da história da Rússia.

\subsubsection{Turquia}

Conforme análise realizada pelo IMF (2004a), os problemas na Turquia emergiram em novembro de 2000, após 10 meses da implantação de um programa para contenção da inflação que apresentava sucesso. Entretanto, a junção entre a crescente necessidade de financiamento do setor público e os elevados riscos no setor bancário levou à crise monetária e bancária, em fevereiro de 2001, com conseqüente troca de regime cambial e subseqüente recessão econômica. 
Durante os anos de 1990, a dívida do setor público cresceu de $10 \%$ para $20 \%$ do PIB, a inflação média chegou a $80 \%$ e as taxas de juros reais foram elevadas para que os papéis do governo fossem aceitos em lira turca.

Como significativa parcela da dívida pública estava em moeda estrangeira, os efeitos das crises na Rússia e no Brasil encurtaram os prazos de pagamento. A análise do balanço do setor bancário permite constatar a piora no ambiente econômico, haja vista a opção por depósitos de curtíssimo prazo e em moeda estrangeira.

Quanto ao ativo, os bancos estavam excessivamente concentrados no setor público. Nesse aspecto, cabe ressaltar que as operações dos bancos estatais causaram profundas distorções no mercado financeiro. A concessão de empréstimos subsidiados a políticos e o acúmulo de recebíveis do governo deterioraram os balanços dos bancos em 37\%.

Para suprir necessidades crescentes de liquidez, esses bancos passaram a captar recursos no “overnight", fomentando a elevação dos juros no interbancário e exacerbando a fragilidade a possíveis choques na taxa de juros e de liquidez.

Ao mesmo tempo, bancos privados estavam enormemente descasados, motivados pela oportunidade de tomar recursos a custo inferior e aplicar na dívida do governo, que oferecia altas taxas de juros. Esse problema de "moral hazard" resultou em um substancial descasamento de moedas no balanço dos bancos, que implicou no aumento dos riscos de liquidez, taxa de juros e câmbio.

Os riscos cresciam tanto pela captação em moeda estrangeira de curto prazo e aplicações em moeda local para o governo, quanto pela elevação dos custos de captação dos depósitos.

O somatório de problemas no setor público e no bancário limitou as opções de políticas para lidar com a crise. Todas as opções produziriam efeitos colaterais difíceis de serem administrados. Nessa circunstância, a defesa da taxa de câmbio com base na taxa de juros tornou-se insustentável e a única saída restante foi implantar um forte ajuste fiscal. 
Assim, houve o aumento das taxas de juros, em novembro de 2000, com queda nos preços dos ativos de renda fixa e aumento no custo de captação. Em fevereiro de 2001, a depreciação da taxa de câmbio colocou os bancos com posições vendidas em insolvência.

À luz da crise no setor bancário, investidores estrangeiros retiraram seus recursos, aumentando ainda mais a pressão sobre a taxa de câmbio. As conseqüências foram o aumento da dívida do setor público em 30 pontos percentuais em relação ao PIB, a alteração no perfil da dívida para restaurar parte da credibilidade perdida, e a troca de cinco bilhões de dólares de dívida em lira por dívida indexada ao dólar para ajudar os bancos a fecharem suas posições.

Finalmente, em um esforço para evitar o colapso do sistema bancário, o governo declarou um cobertor de garantia sobre os passivos dos bancos e emitiu títulos para capitalizá-los. Como resultado, a dívida do governo atingiu quase 30\% do PIB, ao final de 2001.

\subsubsection{Venezuela}

De acordo com Valecillos e Rodríguez (2001), a crise bancária e monetária abrangeu os anos de 1994 e 1995 e causou perdas na ordem de 54\% dos depósitos bancários e perecimento de 47\% do patrimônio líquido dos bancos. Dezoito bancos e um grande número de empresas financeiras e não-financeiras pertencentes aos conglomerados insolventes passaram ao controle do Estado, configurando na maior e mais extensa crise financeira da Venezuela.

A crise financeira foi deflagrada em janeiro de 1994, quando o presidente recém-empossado, em face da decretação do impeachment do presidente anterior, determinou a intervenção no Banco Latino, o segundo maior banco comercial venezuelano, sendo o primeiro em número de correntistas. O motivo divulgado da quebra foi, de um lado, a realização de operações duvidosas para desviar recursos do banco aos próprios controladores, que levaram à insolvência e, de outro, revanchismo político, em face da relação do banco com o governo anterior $^{45}$.

O fechamento disseminou o medo de perder os valores depositados pelos correntistas e depositantes, provocando a maior corrida bancária noticiada na América Latina. Em apenas

45. A fita de vídeo Venezuela: Lições de uma crise, produzida pela TV Bandeirantes, em 1996, apresenta ambas as causas como justificativa da quebra do Banco Latino. 
quinze dias, o equivalente a $5 \%$ do PIB venezuelano foi sacado dos bancos. A conseqüência imediata foi o fechamento de oito bancos por falta de fundos.

A gravidade da situação provocada pelo caos generalizado levou à colocação de tropas militares nas ruas para garantir a ordem. Para amainar, o governo foi obrigado a assumir o controle dos bancos quebrados e realizar o aporte de seis bilhões de dólares.

Segundo Manso (2005, p.6), após a crise, no período entre 1994 e 1996, a Venezuela adotou um regime de câmbio fixo para amortizar os impactos da crise bancária e reestruturar os setores em dificuldades. Entretanto, em 1995, a fragilidade econômica era latente. As significativas despesas de importação e a constante retirada de recursos externos do país, motivada pela recessão econômica, culminou na incapacidade de honrar os compromissos. Esse foi o estopim para a desvalorização da moeda nacional, o Bolívar, em 64,7\%, obrigando a adoção de um regime de bandas cambiais a partir de 1996.

A medida reduziu as taxas de inflação e permaneceu até a crise política de 2002 , quando o regime de câmbio fixo foi novamente imposto pelo governo de Hugo Chaves recémempossado.

\subsubsection{Considerações sobre as experiências de crises financeiras}

A análise das crises financeiras experimentadas em alguns países permite concluir que existem características comuns nos períodos que as antecedem. No campo econômico, as variáveis relacionadas ao câmbio, à taxa de juros, às reservas internacionais e ao produto nacional bruto aparecem em todas as situações.

No aspecto contábil, o sistema bancário debilitado serviu de conduto para agravar e propagar a crise em toda a economia. As informações transparecem tanto no ativo, pela excessiva expansão e baixa qualidade do crédito, associada à redução de ativos líquidos, como no passivo, pelo aumento do endividamento em moeda estrangeira e perda de depósitos.

Observou-se também que os instrumentos utilizados na defesa contra os ataques especulativos foram a desvalorização da moeda, até atingir um novo ponto de equilíbrio, ou a manutenção da paridade, com a utilização de reservas e o aumento da taxa de juros. 
Em uma primeira instância, os países invariavelmente tentaram manter a paridade da moeda intervindo no mercado com a venda de moeda estrangeira e/ou a elevação da taxa de juros. Não obstante, as conseqüências dessas ações por tempo prolongado foram insustentáveis e prejudicais, tanto para o país como para o setor bancário.

No âmbito do país, a utilização indiscriminada das reservas internacionais para manter o valor da moeda nacional diminuiu a quantidade de recursos para honrar os compromissos externos e limitou o poder de intervenção dos bancos centrais no mercado monetário.

Da mesma forma, a elevação da taxa de juros encareceu a rolagem da dívida mobiliária e aumentou o déficit público em relação ao PIB, aumentando a desconfiança na capacidade de pagamento. O resultado foi a redução nos prazos de vencimento da dívida e a exigência de taxas de juros maiores para compensar o aumento no risco.

Para o setor bancário, o aumento e a conservação da taxa de juros em patamar elevado inibiram a intermediação financeira, provocando falta de atratividade ao tomador de crédito bancário e conseqüente diminuição de receitas.

Igualmente, a elevação no custo de captação causado pela maior taxa de juros repercutiu negativamente sobre as operações de crédito já contratadas, pois o risco de inadimplência aumentou para as operações pós-fixadas e a margem de lucro reduziu para as pré-fixadas. A soma desses fatores criou as condições para a ocorrência de quebras generalizadas em instituições financeiras.

Em resumo, o ciclo vicioso instaurado pelo conjunto das situações descritas consumiu as reservas internacionais, enfraqueceu os sistemas bancários e aumentou o custo de cada uma das opções de solução possíveis. A partir desse momento, somente a ajuda financeira externa e fortes ajustes internos foram capazes de reverter a situação das crises instaladas. 


\section{METODOLOGIA DA PESQUISA}

A pesquisa é indutiva e pode ser classificada como empírico-analítica, segundo Martins (2002), ou explicativa, conforme Andrade (2002), pois procura verificar a associação entre variáveis e indicadores econômico-contábeis e o nível de risco sistêmico no setor bancário, com vistas a testar a hipótese de relação entre esses e a ocorrência de crises. Outrossim, a identificação de variáveis e indicadores relevantes permite diagnosticar os fatores determinantes às crises.

Para Martins (2002, p. 34), as pesquisas empírico-analíticas são

[...] abordagens que apresentam em comum a utilização de técnicas de coleta, tratamento e análise de dados marcadamente quantitativas. Privilegiam estudos práticos. Suas propostas têm caráter técnico, restaurador e incrementalista. Têm forte preocupação com a relação causal entre as variáveis. A validação de prova científica é buscada através de instrumentos, graus de significância e sistematização das definições operacionais.

No mesmo sentido, para Andrade (2002, p.20),

[...] é um tipo de pesquisa mais complexo, pois, além de registrar, analisar, classificar e interpretar os fenômenos estudados, procura identificar seus fatores determinantes. A pesquisa explicativa tem por objetivo aprofundar o conhecimento da realidade, procurando a razão, o "porquê" das coisas e por esse motivo está mais sujeita a erros.

A aplicação de testes estatísticos utilizando dados contábeis e econômicos de países onde aconteceram crises bancárias sistêmicas pretende identificar as características comuns que antecedem as crises e possibilitar a construção de uma equação capaz de classificar os países de acordo com a propensão ou não à crise.

A execução dos objetivos do estudo depende da seleção de variáveis econômicas e contábeis com conteúdo informacional sobre risco sistêmico, do estabelecimento de relações significativas entre elas, com vistas à criação dos indicadores, da aplicação de técnicas estatísticas apropriadas, da identificação dos indicadores mais associados à probabilidade de ocorrência de crises e da formulação de uma regra de mensuração do risco sistêmico no setor bancário. 
Adicionalmente, há intenção de conhecer o impacto individual dos riscos de crédito e de mercado, especificamente os de taxa de juros e de câmbio, sobre o capital do sistema bancário, explicitando qual tem maior relevância na composição do risco sistêmico.

\subsection{Desenho da pesquisa}

Para alcançar os objetivos, o desenvolvimento da pesquisa está planejado em seis etapas, conforme exposto na Figura 3 e detalhadas a seguir.

Pesquisa bibliográfica: Analisar os principais estudos referentes ao assunto e elaborar o referencial teórico.

Escopo e método da pesquisa: Definir a amostra, os indicadores, os métodos estatísticos e as hipóteses.

Coleta e análise dos dados: Verificar a qualidade dos dados.

Aplicação dos métodos estatísticos e análise dos resultados:

Validar as equações e os indicadores estatisticamente

Avaliação e aplicação das equações: Generalizar a aplicação em outras situações e interpretar os resultados.

Conclusão: Apresentar as principais contribuições da pesquisa, de acordo com os objetivos estabelecidos.

Figura 3 - Desenho da pesquisa

\section{2 $\quad$ Escopo e método da pesquisa}

Compreende a seleção dos países, dos períodos, das variáveis econômicas e contábeis, das técnicas estatísticas apropriadas, da regra de associação e das hipóteses a serem testadas. 


\subsubsection{Composição da amostra e identificação das crises}

A composição da amostra dependeu precipuamente da existência de informações contábeis e econômicas de países onde ocorreram crises financeiras significativas após 1990. Trinta países atenderam a essa condição e foram selecionados para compor a amostra, sendo divididos em dois grupos com treze e dezessete países cada, representativos dos países com e sem ocorrência de crises, respectivamente.

A título de observação, cabe mencionar que, entre os treze países com experiências de crises, Argentina e Brasil sofreram duas experiências de crises no período, participando duas vezes na amostra e totalizando quinze observações de crise.

Da mesma forma, há países que estiveram ameaçados ou sofreram crises no início dos anos de 1990, como Finlândia, Islândia, Noruega, Dinamarca e Suécia, mas apresentaram sinais de recuperação e foram incluídos no grupo dos países sem crise. Com vistas a evitar a contaminação pelas crises passadas, os dados usados são posteriores a março de 1997, para a Finlândia, junho de 1997, para a Suécia, e dezembro de 1995, para a Dinamarca e a Noruega. A Finlândia, por sua vez, também foi incluída no grupo dos países com experiências de crises, com dados semestrais entre dezembro de 1988 e junho de 1992.

Assim, o principal critério de seleção para inclusão do país no grupo dos países com crise é ter experimentado pelo menos uma crise bancária entre 1990 e 2004, conforme documentado em Lindgren, Garcia e Saal (1996, p.20), Goldstein, Kaminsky e Reinhart (2000, p.24-25), Caprio e Klingebiel (2003), Demirgüç-Kunt e Detragiache (2005), e IMF (1998a). Adicionalmente, houve o foco nos países emergentes em face das conseqüências que uma crise pode causar às suas economias.

Para definir as datas de início das crises, que servem de parâmetros a coleta e análise dos dados, foram considerados os trabalhos mais recentes de Caprio e Klingebiel (2003) e Demirgüç-Kunt e Detragiache (2005), além de outras publicações e trocas de informações com supervisores bancários, especialmente do Brasil, Croácia, Indonésia, Turquia e Rússia.

Com referência ao grupo dos países sem crise, houve a seleção de países-membro da OECD (Organization for Economic Co-operation and Development), que aparentemente não tenham experimentado, no período, crise no sistema bancário. 
Nesse particular, é de conhecimento que alguns países apresentaram aumento no risco sistêmico, como a Espanha, pela quebra do Banesto ${ }^{46}$, em dezembro de 1993, e a França, pela reestruturação do Crédit Lyonnais ${ }^{47}$, em 1994. Não obstante, a expectativa é que a análise estatística perceba esses fatos para mensurar o nível de risco e apresente as evidências nos resultados.

A relação dos países selecionados e as respectivas datas de início das crises apontadas nos trabalhos mencionados, bem como a data de início adotada no estudo, estão na Tabela 8 .

Tabela 8 - Países selecionados e datas das crises

\begin{tabular}{|c|c|c|c|c|c|c|c|}
\hline \multirow[t]{2}{*}{$\mathbf{N}$. } & \multirow{2}{*}{\begin{tabular}{|l|}
$\begin{array}{l}\text { Países com } \\
\text { crises }\end{array}$ \\
\end{tabular}} & \multicolumn{5}{|c|}{ Data de início das crises bancárias } & \multirow[t]{2}{*}{ Países sem crises } \\
\hline & & G,K\&R & C\&K & IMF & D-K\&D & Adotada & \\
\hline \multirow{2}{*}{$\begin{array}{l}1 \\
2\end{array}$} & \multirow[t]{2}{*}{ Argentina } & \multirow[t]{2}{*}{ Dez/1994 } & \multirow[t]{2}{*}{1995} & \multirow[t]{2}{*}{1995} & \multirow[t]{2}{*}{2002} & \multirow{2}{*}{$\begin{array}{c}\text { Mar/1995 e } \\
\text { Dez/2001 }\end{array}$} & 1.Alemanha \\
\hline & & & & & & & 2. Austrália \\
\hline \multirow{2}{*}{$\begin{array}{l}3 \\
4\end{array}$} & \multirow[t]{2}{*}{ Brasil } & \multirow[t]{2}{*}{ Dez/1994 } & \multirow[t]{2}{*}{ 1994-99 } & \multirow[t]{2}{*}{$1994-99$} & \multirow[t]{2}{*}{$1994-99$} & \multirow{2}{*}{$\begin{array}{c}\text { Dez/1995 e } \\
\text { Dez/1998 }\end{array}$} & 3. Áustria \\
\hline & & & & & & & 4. Islândia \\
\hline 5 & Equador & n.a.* & $1996-97$ & n.a.* & $1995-02$ & Mar/1999 & 5. Canadá \\
\hline 6 & México & Out/1992 & 1995 & 1994 & $1994-97$ & Dez/1994 & 6. Espanha \\
\hline 7 & Venezuela & Out/1993 & 1994 & 1993 & $1993-97$ & Dez/1993 & 7. Estados Unidos \\
\hline 8 & Indonésia & Nov/1992 & 1997 & 1997 & $1997-02$ & Dez/1997 & 8. Finlândia \\
\hline 9 & Coréia do Sul & Jul/1997 & 1997 & 1997 & 1997-02 & Dez/1997 & 9. França \\
\hline 10 & Finlândia & set/1992 & 1991 & 1991 & 1991 & Dez/1991 & 10. Holanda \\
\hline 11 & Uruguai & n.a.* & n.a* & n.a* & 2002 & Mar/2002 & 11. Itália \\
\hline 12 & Tailândia & Mai/1996 & 1997 & 1997 & 1997-02 & Set/1997 & 12. Reino Unido \\
\hline 13 & Turquia & n.a.* & n.a* & n.a* & $2000-02$ & Mar/2001 & 13. Suécia \\
\hline 14 & Rússia & n.a. & 1998 & n.a. & n.a. & Set/1998 & 14. Noruega \\
\hline \multirow[t]{3}{*}{15} & Croácia & n.a & 1996 & n.a. & n.a. & Dez/1998** & 15. Nova Zelândia \\
\hline & & & & & & & 16. Portugal \\
\hline & & & & & & & 17. Dinamarca \\
\hline
\end{tabular}

* crise não contemplada no estudo.

** informação do órgão de supervisão do país.

G,K \& R - Goldstein, Kaminsky e Reinhart (2000, p.24-25). C \& K - Caprio e Klingebiel (2003). IMF International Monetary Fund (1998a). D-K\&D - Demirgüç-Kunt e Detragiache (2005).

Nos casos em que a data da crise não coincide com a data do balancete ou balanço, a data escolhida corresponde ao balancete ou balanço da data imediatamente anterior.

A condição determinante à manutenção do país na amostra é o acesso aos dados que compõem os indicadores. Todavia, houve a intenção de incorporar a maior quantidade possível de países aos grupos, observada a proporcionalidade numérica entre eles.

46. O Banesto era o quinto maior banco espanhol, em dezembro de 1993, e apresentou perdas de 4,7 bilhões de dólares, para um total de ativos de 43 bilhões de dólares (JORION, 2003, p.30).

47. O Crédit Lyonnais era o maior banco público francês, em 1994, e precisou ser reestruturado com aporte de recursos do governo no valor de 15 bilhões de dólares (JORION, 2003, p.30). 


\subsubsection{Seleção de indicadores}

Os indicadores selecionados buscam fornecer informações sobre a solidez econômica e financeira da posição agregada das instituições financeiras bancárias, bem como aferir a influência do ambiente econômico.

Neste particular, como não existe um conjunto universalmente aceito para avaliar instituições e sistemas indiscriminadamente, contemplando todas as variáveis existentes, a escolha foi discricionária e recaiu sobre aqueles usados na estrutura CAMELS, amplamente utilizada por supervisores bancários em todo o mundo e também adotados para construir os $\mathrm{FSI}^{48}$ empregados pelo IMF e BIS (EVANS, 2000).

As rubricas contábeis utilizadas nos indicadores contêm informações sobre o patrimônio líquido, o ativo total, os ativos líquidos, os créditos normais e vencidos, o total de depósitos e a posição líquida em moeda estrangeira.

Além disso, com vistas a utilizar o conceito de risco, alguns indicadores contábeis agregam a volatilidade do período sob análise no cálculo. O objetivo é mensurar o impacto de perdas não-esperadas sobre as variáveis que deveriam suportá-las. Por exemplo, a perda nãoesperada oriunda da volatilidade dos créditos anormais deve ser coberta pelo patrimônio líquido, assim como a volatilidade nos depósitos deve ser suportada pelos ativos líquidos.

Igualmente, para aferir a influência do ambiente econômico, os indicadores utilizam as variáveis econômicas que demonstraram relevância nos estudos pesquisados e são associadas aos riscos de crédito, de taxa de juros e de câmbio existentes nas variáveis contábeis.

Os indicadores econômico-contábeis (de riscos) estão formulados com base na definição do VaR (JORION, 2003, p.96) e na função do patrimônio líquido (BCBS, 1988), contemplando os três fatores presumivelmente determinantes à existência e à quantificação dos riscos:

a) Volatilidade da variável econômica ou contábil que evidencia o risco específico.

b) Exposição ao risco específico, demonstrado pela contabilidade.

c) Nível de capitalização, expresso pelo saldo do patrimônio líquido.

48. Relacionados na seção 2.2.2.2. 
O impacto das perdas não-esperadas sobre as variáveis contábeis é estabelecido pelo dimensionamento da alteração do valor em risco ( $\mathrm{VaR})$ resultante das oscilações nas variáveis econômicas e contábeis.

A expectativa é que tanto os indicadores econômico-contábeis, nos quais está intrínseco o conceito do valor em risco ou da perda não-esperada, como os indicadores contábeis, apresentem poder explicativo e grau de associação com a ocorrência de crises bancárias sistêmicas.

\subsubsection{Indicadores contábeis}

Os indicadores formulados com base em variáveis contábeis são os seguintes:

a) Indicador do ativo total sobre o patrimônio líquido (ATPL), calculado pela fórmula:

$$
A T P L=\frac{A T}{P L}
$$

onde AT é o valor do ativo total e PL é o valor do patrimônio líquido.

A relação entre o volume de ativos e o valor do patrimônio líquido expressa o grau de alavancagem, que contém a informação da proporção de recursos de terceiros utilizada em relação aos recursos próprios para fundear as operações ativas. Quanto maior a participação de recursos de terceiros, maior o risco, pois a obtenção de resultados torna-se imperativa ao pagamento dos recursos captados acrescidos de juros.

No segmento bancário, a alavancagem é usualmente elevada, mas limitada pela regulamentação de cada país, haja vista que a característica operacional da atividade de intermediação financeira incentiva a maximização das captações e aplicações. Nesse contexto, a premissa é que o patrimônio líquido apresente valor compatível com o volume de ativos, sendo suficiente para cobrir possíveis variações adversas como a perda de qualidade, a desvalorização ou a insubsistência desses ativos. 
Assim, quando não há variação proporcional entre as duas variáveis, como por exemplo o aumento dos ativos ou a redução do patrimônio líquido, a exposição ao risco aumenta. A expectativa é que o indicador evidencie as alterações nas variáveis, apresentando sinal positivo na relação com o nível de risco sistêmico.

b) Indicador de participação dos ativos líquidos sobre o total de depósitos (ALDT), calculado pela fórmula:

$A L D T=\frac{A L}{D T}$

onde AL é o valor dos ativos líquidos e DT é o valor do total de depósitos.

A relação entre os ativos líquidos e os depósitos totais expressa a liquidez existente, sendo que o ativo líquido é calculado pelo somatório das disponibilidades, aplicações interfinanceiras de liquidez e títulos livres, menos os valores aportados pelas autoridades monetárias na forma de assistência financeira de liquidez.

Como os depósitos, em geral, representam a principal fonte de recursos para o sistema bancário, mas podem ser sacados aleatoriamente, as instituições preventivamente mantêm parte dos depósitos aplicados em ativos líquidos. Quanto maior esse montante de recursos em relação aos depósitos, maior a capacidade de atender aos eventuais saques, sem comprometer o rendimento de outros ativos que precisariam ser realizados antecipadamente.

Assim, dado que a maior liquidez representa menor risco, a expectativa é que o indicador apresente sinal negativo na relação com o nível de risco sistêmico.

c) Indicador da taxa de inadimplência (CAOC), calculado pela fórmula:

$C A O C=\frac{C A}{O C}$

onde CA é o valor dos créditos anormais (vencidos) e OC é o valor das operações de crédito. 
A divisão das operações de crédito em situação anormal (vencidas) sobre as operações de crédito informa o percentual de inadimplência existente no sistema. Posto que a situação econômico-financeira do sistema bancário depende diretamente do volume e da qualidade dos ativos administrados e dado que as operações de crédito representam, usualmente, a principal aplicação do sistema bancário, a relação entre os créditos vencidos e as operações de crédito permite a extração de conclusões sobre a saúde do sistema, bem como sobre as perspectivas de geração de resultados.

O processo de insolvência das instituições é normalmente originado na incapacidade de gerar receitas suficientes para cobrir as despesas, podendo ser conseqüência tanto do baixo volume operacional como da má qualidade dos ativos. A deterioração na qualidade do crédito significa maior risco e a expectativa é que o indicador apresente sinal positivo na relação com o nível de risco sistêmico.

d) Indicador da posição líquida em moeda estrangeira sobre o patrimônio líquido (NOPPL), calculado pela fórmula:

$N O P P L=\frac{N O P}{P L}$

onde NOP é a posição líquida em moeda estrangeira e PL é o patrimônio líquido.

A posição líquida em moeda estrangeira é obtida pela diferença entre os somatórios das posições ativas e passivas em moeda estrangeira. $\mathrm{O}$ sinal positivo indica uma posição líquida ativa e o sinal negativo uma posição líquida passiva.

Nos países emergentes, normalmente são encontradas exposições passivas decorrentes do endividamento externo. Em situações de crise, a desvalorização da moeda local provoca o aumento dessas exposições em moeda estrangeira, originando despesas de variações monetárias nos resultados, com conseqüente diminuição do patrimônio líquido.

Assim, há necessidade de avaliar a participação da posição líquida em moeda estrangeira em relação ao patrimônio líquido, a fim de verificar o nível do possível comprometimento. Considerando o significado do sinal, quanto menor o indicador (mais negativo), maior o nível de risco sistêmico. 
e) Indicador de rentabilidade do patrimônio líquido (ROE), calculado pela fórmula:

$R O E=\frac{R S L}{P L}$

onde RSL é o resultado líquido do exercício e PL é o patrimônio líquido.

A razão entre o resultado do período e o valor do patrimônio líquido exprime quanto o sistema bancário obtém de retorno sobre os recursos próprios investidos. A importância da informação reside na concepção de que os resultados constituem o principal item de sustentação do capital. Por esse motivo, o volume de resultados auferido pelo sistema bancário de cada país representa uma variável essencial à avaliação do desempenho.

Somente mediante à obtenção de resultados positivos sucessivos, as instituições e o sistema têm a possibilidade de manter constância operacional. Prejuízos reduzem o capital e enfraquecem a credibilidade no sistema. Não obstante à relevância do ROE, a interpretação carece de atenção, pois um valor alto pode ser conseqüência tanto de resultados positivos elevados como do baixo nível de capitalização. Inversamente, um indicador baixo pode representar tanto resultados insignificantes como alta capitalização.

Por isso, recomenda-se observar o indicador junto com o indicador de alavancagem, a fim de evitar conclusões inapropriadas. Como os resultados positivos são fontes de recursos e fortalecem o patrimônio líquido, a expectativa é que o indicador apresente sinal negativo com o nível de risco sistêmico.

\subsubsection{Indicadores de risco}

Os indicadores que consideram a volatilidade dos índices econômicos e das variáveis contábeis são os seguintes $^{49}$ :

a) Indicador de mensuração do impacto da variação da taxa de câmbio sobre o patrimônio líquido (IRFX), denominado índice de risco de câmbio e calculado pelas fórmulas:

49. Os indicadores de risco foram desenvolvidos pelo autor a partir de conceitos contábeis e de finanças. 
$\operatorname{IRFX}(H ; c)=\frac{-\alpha^{*} \sigma_{F X T J} *(V \operatorname{Exp} F X)}{P L}$

e

$\sigma_{F X T J}=\left[\left(w_{F X}^{2} * \sigma_{F X}^{2}\right)+\left(w_{T J}^{2} * \sigma_{T J}^{2}\right)+2 * w_{F X} * w_{T J} * \rho_{F X T J} * \sigma_{F X} * \sigma_{T J}\right]^{1 / 2}$

onde, na equação (15), $H$ é igual a quatro trimestres, correspondente ao horizonte de tempo para o cálculo da volatilidade e correlação; $c$ é o intervalo de confiança estabelecido para o cálculo do valor em risco, no caso é igual a 99\%; - $\alpha$ é igual a 2,33, valor correspondente ao intervalo de confiança unilateral encontrado na tabela de distribuição normal padronizada; $\sigma_{F X T J}$ é o desvio-padrão conjunto das taxas de câmbio e de juros, calculado pela equação (16); $V E x p F X$ é o valor contábil líquido exposto à variação cambial, obtido pela diferença entre ativos e passivos (posição líquida) referenciados em moeda estrangeira; e $P L$ é o patrimônio líquido, na data do balancete ou balanço.

Na equação (16), $\sigma_{F X T J}$ é o desvio-padrão conjunto das taxas de câmbio e de juros; $W_{F X}$ é a proporção referenciada em moeda estrangeira; $\sigma_{F X}$ é o desvio-padrão da taxa de câmbio; $W_{T J}$ é a proporção referenciada em taxa de juros; $\sigma_{T J}$ é o desvio-padrão da taxa de juros; e $\rho_{F X T J}$ é a correlação entre a taxa de câmbio e a taxa de juros no período $H$.

O objetivo do indicador é mostrar a capacidade do patrimônio líquido suportar variações adversas na taxa de câmbio. Considerando a volatilidade observada nos quatro períodos anteriores, a posição líquida em moeda estrangeira existente e um intervalo de confiança de 99\%, calcula-se o impacto máximo que a variação pode causar sobre o patrimônio líquido.

A informação do indicador expressa o nível de comprometimento, sendo que o valor inferior a um $($ IRFX < 1) significa a existência de patrimônio líquido em valor suficiente para absorver as variações máximas possíveis na taxa de câmbio, para o intervalo de confiança estipulado. De forma contrária, o valor superior a um $($ IRFX $>1)$ denota insuficiência de patrimônio líquido para absorver essas variações. A expectativa é que o indicador apresente sinal positivo na relação com o nível de risco sistêmico. 
b) Indicador de mensuração do impacto da variação da taxa de juros sobre o patrimônio líquido (IRTJ), denominado índice de risco de taxa de juros e calculado pela fórmula:

$\operatorname{IRTJ}(H ; c)=\frac{-\alpha^{*} \sigma_{F X T J} *(V \operatorname{Exp} T J)}{P L}$

onde, na equação (17), $H$ é igual a quatro trimestres, correspondente ao horizonte de tempo para o cálculo da volatilidade e correlação; $c$ é o intervalo de confiança estabelecido para o cálculo do valor em risco, no caso é igual a 99\%; - $\alpha$ é igual a 2,33, valor correspondente ao intervalo de confiança unilateral encontrado na tabela de distribuição normal padronizada; $\sigma_{F X T J}$ é o desvio-padrão conjunto das taxas de câmbio e de juros, calculado pela equação (16); $V \operatorname{Exp} T J$ é o valor contábil líquido exposto à variação da taxa de juros, obtido pela diferença entre ativos e passivos (posição líquida) referenciados em taxa de juros; e $P L$ é o patrimônio líquido, na data do balancete ou balanço.

Similarmente ao índice de risco de câmbio, a finalidade do indicador é mostrar a capacidade do patrimônio líquido suportar variações adversas na taxa de juros. Considerando a volatilidade observada nos quatro períodos anteriores, a posição líquida exposta à taxa de juros existente na data e um intervalo de confiança de $99 \%$, calcula-se o valor máximo que pode causar impacto sobre o patrimônio líquido.

A informação do indicador expressa o nível de comprometimento, sendo que o valor inferior a um (IRTJ < 1) significa a existência de patrimônio líquido em valor suficiente para absorver as variações máximas possíveis na taxa de juros, para o intervalo de confiança estipulado. $\mathrm{O}$ contrário, no qual o valor é superior a um (IRTJ > 1), evidencia que o patrimônio líquido é insuficiente para absorver essas variações. Como um índice de risco, a expectativa é que o indicador apresente sinal positivo na relação com o nível de risco sistêmico.

c) Indicador de mensuração do impacto da variação dos créditos anormais sobre o patrimônio líquido (IRCré), denominado índice de risco de crédito e calculado pela fórmula:

$\operatorname{IRCRE}(H ; c)=\frac{-\alpha^{*} \sigma_{T I} *(V \operatorname{Exp} C R E)}{P L}$ 
onde $H$ é igual a quatro trimestres, correspondente ao horizonte de tempo para o cálculo da volatilidade e correlação; $c$ é o intervalo de confiança estabelecido para o cálculo do valor em risco, no caso é igual a 99\%; - $\alpha$ é igual a 2,33, valor correspondente ao intervalo de confiança unilateral encontrado na tabela de distribuição normal padronizada; $\sigma_{T I}$ é o desvio-padrão da taxa de inadimplência, obtida pela razão entre o montante de créditos anormais (vencidos) e o total das operações de crédito; VExpCRE é o valor contábil dos ativos sujeitos ao risco de crédito e $P L$ é o patrimônio líquido, na data do balancete ou balanço.

A finalidade do indicador é mostrar a capacidade do patrimônio líquido suportar variações no percentual de créditos anormais em relação às operações de crédito. Com base na volatilidade observada na taxa de inadimplência nos quatro períodos anteriores, o volume de créditos existente na data e um intervalo de confiança de $99 \%$, calcula-se o valor máximo que pode causar impacto sobre o patrimônio líquido.

A informação do indicador expressa o nível de comprometimento, sendo que o valor inferior a um (IRCRE < 1) significa a existência de patrimônio líquido em valor suficiente para absorver as variações máximas possíveis na taxa de inadimplência, para o intervalo de confiança estipulado. O oposto, com valor superior a um (IRCRE $>1$ ), denota que o patrimônio líquido é insuficiente para absorver essas variações. Semelhante aos índices anteriores, o indicador deve apresentar sinal positivo com o nível de risco sistêmico.

d) Indicador de mensuração do impacto da variação dos depósitos totais sobre os ativos líquidos (IRLIQ), denominado índice de risco de liquidez e calculado pela fórmula:

$$
\operatorname{IRLIQ}(H ; c)=\frac{-\alpha^{*} \sigma_{D T}}{A L}
$$

onde $H$ é igual a quatro trimestres, correspondente ao horizonte de tempo para o cálculo da volatilidade e correlação; $c$ é o intervalo de confiança estabelecido para o cálculo do valor em risco, no caso é igual a 99\%; - $\alpha$ é igual a 2,33, valor correspondente ao intervalo de confiança unilateral encontrado na tabela de distribuição normal padronizada; $\sigma_{D T}$ é o desvio-padrão do depósito total; e $A L$ é o valor dos ativos líquidos na data do balanço ou balancete. 
O objetivo do indicador é demonstrar se os ativos líquidos suportam as variações provocadas pelos saques em depósitos totais. Considerando a volatilidade observada nos depósitos totais nos quatro períodos anteriores, para um nível de confiança de $99 \%$, calcula-se o valor máximo de retiradas de depósitos que devem ser cobertos pelos ativos líquidos.

A informação do indicador expressa o nível de exigência dos ativos líquidos, sendo que o valor inferior a um (IRLIQ < 1) significa a existência de volume suficiente de ativos líquidos para honrar os saques máximos em depósitos, para o intervalo de confiança estipulado. Contrariamente, o valor superior a um (IRLIQ > 1) expressa a insuficiência de ativos líquidos frente ao volume possível de retiradas nos depósitos. A expectativa, igualmente aos demais, é que o indicador apresente sinal positivo na relação com o nível de risco sistêmico.

e) Indicador de mensuração da variação do ativo total em relação ao produto interno bruto (ATPIB), calculado pela fórmula:

$\operatorname{IRATPIB}(H ; c)=\frac{-\alpha^{*} \sigma_{A T}+A T}{P I B}$

onde $H$ é igual a quatro trimestres, correspondente ao horizonte de tempo para o cálculo da volatilidade e correlação; $c$ é o intervalo de confiança estabelecido para o cálculo do valor em risco, no caso é igual a 99\%; - $\alpha$ é igual a 2,33, valor correspondente ao intervalo de confiança unilateral encontrado na tabela de distribuição normal padronizada; $\sigma_{A T}$ é o desvio-padrão do ativo total; e $A T$ é o valor do ativo total na data do balanço ou balancete, e PIB é o produto interno bruto.

O indicador busca demonstrar se o valor do PIB é compatível com o valor do ativo total existente no sistema bancário, acrescido da respectiva variação. No cálculo é observada a volatilidade do ativo total nos quatro períodos anteriores, o montante de ativo total na data e um intervalo de confiança de $99 \%$.

A informação contida no indicador possibilita verificar se há correspondência entre o valor do ativo total existente no sistema bancário, incluindo sua variação, e o PIB. O valor inferior a um (IRATPIB < 1) evidencia que o volume de ativos no sistema é compatível com o volume do PIB, não ensejando maiores preocupações quanto à realização dos ativos financeiros em 
ativos reais. De forma oposta, o valor superior a um (IRATPIB $>1$ ) informa que a riqueza do país é inferior ao volume de ativos financeiros. Esse descasamento pode levar a desconfiança sobre a conversibilidade dos ativos financeiros em ativos reais e precipitar a fuga de recursos do sistema bancário. Por esse motivo, a expectativa é que o indicador apresente sinal positivo com o nível de risco sistêmico

\subsection{Métodos estatísticos}

\subsubsection{Janela do evento}

Como existe a percepção de que os motivos causadores de crises são crescentes e progressivos, com manifestação em períodos anteriores, os dados selecionados para efetuar os testes são referentes aos quatro períodos que antecedem a data provável de início da crise ${ }^{50}$, sendo utilizados preferencialmente os dados trimestrais.

Entretanto, a regressão logística não apresenta resultados satisfatórios quando há poucas observações (países) relativamente ao número de variáveis (indicadores) utilizado na estimação (SPSS, 2003). Considerando a escolha de dez indicadores, o número de indicadores nos quatro períodos atinge 40, totalizando 1.280 para uma amostra de 32 observações. Para contornar a limitação da técnica, houve a síntese das informações dos quatro períodos em um indicador único.

Assim, os valores correspondentes à média, ao desvio-padrão e ao coeficiente de variação dos quatro indicadores que antecedem as crises são os indicadores submetidos aos testes.

Em face da utilização desses valores representativos dos indicadores, faz-se importante ressaltar a mudança na interpretação. Enquanto as médias acompanham as interpretações individuais dos indicadores originais em relação ao risco sistêmico, os desvios-padrão e os coeficientes de variação são interpretados diferentemente, pois são sempre positivamente relacionados com o risco sistêmico e interpretados na forma quanto maior o indicador, maior o risco.

50. As datas de início das crises foram obtidas a partir dos estudos de Caprio e Klingebiel (2003) e DemirgüçKunt e Detragiache (2005), apresentadas na Tabela 8, bem como de informações dos próprios supervisores bancários dos países afetados e de notícias veiculadas pelos organismos internacionais como o IMF e o BIRD. 
As planilhas com as variáveis contábeis e econômicas, bem como os detalhes dos cálculos dos indicadores estão no Apêndice 2.

\subsubsection{Estatística descritiva}

A utilização da estatística descritiva busca demonstrar os valores máximos e mínimos, as medidas de tendência central, como a média, a mediana e o desvio-padrão, e os valores máximos e mínimos de cada um dos indicadores.

A principal preocupação é com a dispersão dos indicadores. Dado que as técnicas estatísticas geralmente utilizam o método dos mínimos quadrados ou da máxima verossimilhança, como a regressão logística, para verificar as relações, há interesse em identificar os indicadores próximos à média do grupo a que pertencem, com ou sem crise, e distantes da média geral.

A fórmula de Fisher traduz precisamente a relação desejada:

$$
F=\frac{X-x_{i}}{Y-x_{i}}
$$

onde $X$ é a média geral da amostra, $Y$ é a média de um dos grupos e $x_{i}$ é o indicador testado. A interpretação é de quanto maior o $F$, mais o indicador está distante da média geral e próximo da média do grupo, contendo maior capacidade de discriminação.

Indicadores com maior dispersão em relação às médias dos grupos de crise e não-crise, ou concentrados na média geral, dificultam a segregação dos grupos, pois a variância dos seus valores abrange características comuns, ou nenhuma, não permitindo a diferenciação.

Outro problema apurado na estatística descritiva é a existência de dados anormais (outliers). A expectativa de ocorrência é limitada, devendo ser oriunda de alterações nas séries temporais ou nos critérios de mensuração.

Adicionalmente, para tratar possíveis problemas de multicolinearidade entre as variáveis explicativas (MATOS, 2000, p.124-129), os indicadores são submetidos à análise de correlação. A eliminação de um dos indicadores com coeficiente de correlação superior a 70\% 
evita o uso de informações semelhantes de dois ou mais indicadores na explicação ou previsão da variável dependente, coibindo assim a obtenção de resultado espúrio.

Caso a análise fatorial mostre-se apropriada e construa fatores compreensíveis e utilizáveis, a correlação é automaticamente eliminada, sendo desnecessária a preocupação com problemas de multicolinearidade.

\subsubsection{Análise fatorial}

A análise fatorial é uma técnica de análise multivariada, na qual todas as variáveis são simultaneamente consideradas, com o objetivo de analisar as inter-relações existentes, buscando a redução ou a sumarização dos dados (HAIR et al., 1998, p.90).

Consiste em uma modelagem matemática que tenta explicar a correlação entre um grande conjunto de variáveis em termos de um pequeno número de fatores fundamentais. A redução ou a sumarização da quantidade de dados visa facilitar a modelagem e a compreensão dos dados.

Ao transformar as variáveis originais em fatores, por meio da combinação linear das medidas de variâncias, a análise fatorial considera relações subjacentes das variáveis ainda não identificadas, explicitando informações até então despercebidas. O novo arranjo é obtido em função dos maiores valores informativos das variáveis para cada fator.

As variáveis que formam um fator apresentam alta correlação entre si, mas têm pouca ou nenhuma correlação com variáveis de outro grupo, e representam determinado aspecto do objeto estudado.

Para obtenção de resultados satisfatórios, Pereira (2001, p. 124) explica que os dados submetidos à análise fatorial devem atender a alguns requisitos, os quais são medidos por testes específicos.

Um deles é o KMO (Kaiser-Meyer-Olkin Measure of Sampling Adequacy), que analisa a adequação da técnica com base no grau de correlação dos dados. Para tanto, calcula a razão entre as correlações das variáveis originais e as correlações das variáveis originais mais as 
correlações dos fatores. O quociente mais próximo a um (1) indica dados adequados e maior benefício na utilização da análise fatorial.

Outro teste é o de esfericidade de Bartlett (Bartlett Test of Sphericity), que verifica se a correlação entre as variáveis é significativa, a ponto de apenas alguns fatores serem suficientes para representar a maior parte da variabilidade dos dados. A técnica é considerada apropriada quando é possível rejeitar que não há correlação entre as variáveis ao nível de significância estipulado (HAIR et al., 1998, p.99).

Além disso, por ser indicada para diminuir a quantidade de variáveis e a complexidade na compreensão, a técnica tem maior eficácia quando houver elevado número de variáveis originais e reduzida quantidade de observações, pois, caso contrário, existe o risco de formar mais fatores do que as variáveis originais.

Em termos matemáticos, as variáveis observáveis $X_{1}, X_{2}, \ldots, X_{p}$, com médias $\mu_{1}, \mu_{2}, \ldots, \mu_{p}$, podem ser representadas por um modelo baseado na combinação linear das variáveis nãoobserváveis $F_{1}, F_{2}, \ldots, F_{i}(i=1,2,3, \ldots, k)$, da seguinte forma:

$X_{1}-\mu_{1}=\lambda_{11} F_{1}+\lambda_{12} F_{2}+, \ldots,+\lambda_{1 k} F_{k}$
$X_{2}-\mu_{2}=\lambda_{21} F_{1}+\lambda_{22} F_{2}+, \ldots,+\lambda_{1 k} F_{k}$
$\ldots$
$X_{p}-\mu_{p}=\lambda_{p 1} F_{1}+\lambda_{p 2} F_{2}+, \ldots,+\lambda_{p k} F_{k}$

Os coeficientes $\lambda_{i j}(i=1,2, \ldots, p$ e $j=1,2, . ., k)$ são parâmetros que refletem a importância de cada variável na formação de um fator e são denominados de carga fatorial. A expectativa é que algumas variáveis, ou ao menos uma, sejam relevantes e apresentem coeficientes elevados em determinado fator. Dessa forma, cada fator pode ser assim representado:

$F_{i}=\lambda_{i j} X_{j}=\lambda_{i 1} X_{1}+\lambda_{i 2} X_{2}+\ldots+\lambda_{i p} X_{p}$

onde $F_{i}$ é o fator $(i=1,2, \ldots, k), \lambda_{i j}$ são os coeficientes do fator, e $X_{1}, X_{2}, \ldots X_{p}$ são as variáveis originais. 
No estudo, a intenção é reduzir ou sumarizar a significativa quantidade de indicadores em um número menor de fatores. A expectativa é construir fatores que sintetizem adequadamente os riscos inerentes às atividades de instituições financeiras, formando construtos explicativos do risco de crédito, de taxa de juros, de câmbio e de liquidez. Em tal circunstância, as variáveis originais podem ser substituídas pelos fatores na aplicação da regressão logística.

\subsubsection{Regressão logística}

A escolha da análise de regressão logística (LOGIT) é justificada pela necessidade de estimar a probabilidade de ocorrência, ou não, de crises bancárias sistêmicas, com base em um conjunto de variáveis explanatórias, definidas na forma de indicadores contábeis e de riscos, calculados com e sem a volatilidade.

A natureza categórica binária da variável dependente, de crise ou não-crise, recomenda o uso da LOGIT pelo benefício de mostrar os resultados em probabilidades, classificar as observações em grupos, ter interpretação similar à regressão linear, exigir poucos pressupostos estatísticos para os dados, como o comportamento probabilístico de normalidade multivariada, e conter alta confiabilidade (HAIR et al., 1998, p.276).

Para tanto, a técnica calcula a razão entre a probabilidade de ocorrência e não-ocorrência do evento (crise e não-crise) constante na amostra, denominada razão de chances ${ }^{51}$. Em seguida, realiza a transformação logarítmica dessa razão, que representa a variável dependente da equação linear que estima os coeficientes. A estimação dos coeficientes é realizada pelo critério da máxima verossimilhança, de forma a obter a melhor regra de classificação associada ao evento.

A equação utilizada no cálculo é:

$$
\ln \left(\frac{P\left(\text { evento }_{i}\right)}{1-P\left(\text { evento }_{i}\right)}\right)=\beta_{0}+\beta_{1} X_{i}+\beta_{2} X_{i}+\ldots+\beta_{n} X_{i}
$$


onde $\ln$ é o logaritmo natural, $P$ (evento) é a probabilidade de ocorrência do evento $i, \beta$ são os coeficientes estimados e $X$ as variáveis independentes.

Nesse ponto, faz-se importante observar que a LOGIT calcula as modificações no logaritmo da variável dependente. Por esse motivo, após a obtenção dos resultados, a interpretação requer o cálculo do antilogaritmo dos coeficientes estimados.

Para eliminar a função logarítmica, os dois lados da equação são considerados como expoentes da constante matemática $e$ (igual a 2,71828), resultando na equação (HAIR et al., 1998, p.278):

$\left(\frac{P\left(\text { evento }_{i}\right)}{1-P\left(\text { evento }_{i}\right)}\right)=e^{\left(\beta_{0}+\beta_{1} X_{i}+\beta_{2} X_{i}+\ldots+\beta_{n} X_{i}\right)}$

Os coeficientes estimados são então multiplicados pelas variáveis independentes de cada observação e o resultado é a probabilidade de ocorrência do evento. A equação logística utilizada para esse cálculo é a seguinte (HOSMER; LEMESHOW, 1989, p.26):

$$
P\left(\text { evento }_{i}\right)=\frac{e^{\left(\beta_{0}+\beta_{1} X_{i}+\beta_{2} X_{i}+\ldots+\beta_{n} X_{i}\right)}}{1+e^{\left(\beta_{0}+\beta_{1} X_{i}+\beta_{2} X_{i}+\ldots+\beta_{n} X_{i}\right)}}
$$

ou, na forma simplificada, conforme Gujarati (2000, p.559) e Saunders (2000, p.211):

$$
P\left(\text { evento }_{i}\right)=\frac{1}{1+e^{-\left(\beta_{0}+\beta_{1} X_{i}+\beta_{2} X_{i}+\ldots+\beta_{n} X_{i}\right)}}
$$

A complementaridade das probabilidades de ocorrência e não ocorrência do evento, com soma igual a um, permite concluir que a probabilidade de não ocorrência $\left(1-P\left(\right.\right.$ evento $\left.\left._{i}\right)\right)$ é dada pela fórmula ${ }^{52}$ :

$$
1-P\left(\text { evento }_{i}\right)=\frac{1}{1+e^{\left(\beta_{0}+\beta_{1} X_{i}+\beta_{2} X_{i}+\ldots+\beta_{n} X_{i}\right)}}
$$

52. A equação (29) resulta na curva logística inversa. 
No caso, as variáveis independentes $X$ assumem os valores dos indicadores contábeis e de riscos. Já a variável dependente da probabilidade de ocorrência de crise no país $i, P\left(\right.$ evento $\left._{i}\right)$, assume os valores:

$P\left(\right.$ evento $\left._{\mathrm{i}}\right)=1$, se há crise; $\mathrm{e}$

$P\left(\right.$ evento $\left._{\mathrm{i}}\right)=0$, se não há crise.

Pelo resultado da equação (26) ou (27), a classificação ocorre da seguinte maneira, conforme pode ser verificado graficamente na Figura 4:

a) Se o resultado da equação linear é maior do que zero $(Z(i)>0)$, o resultado da equação logística é maior do que $0,5(\mathrm{P}(1)>0,5)$, e o país é classificado como suscetível à crise.

b) Caso contrário $(\mathrm{Z}(\mathrm{i})<0$ e $\mathrm{P}(1)<0,5)$, o país é classificado como não-suscetível à crise.

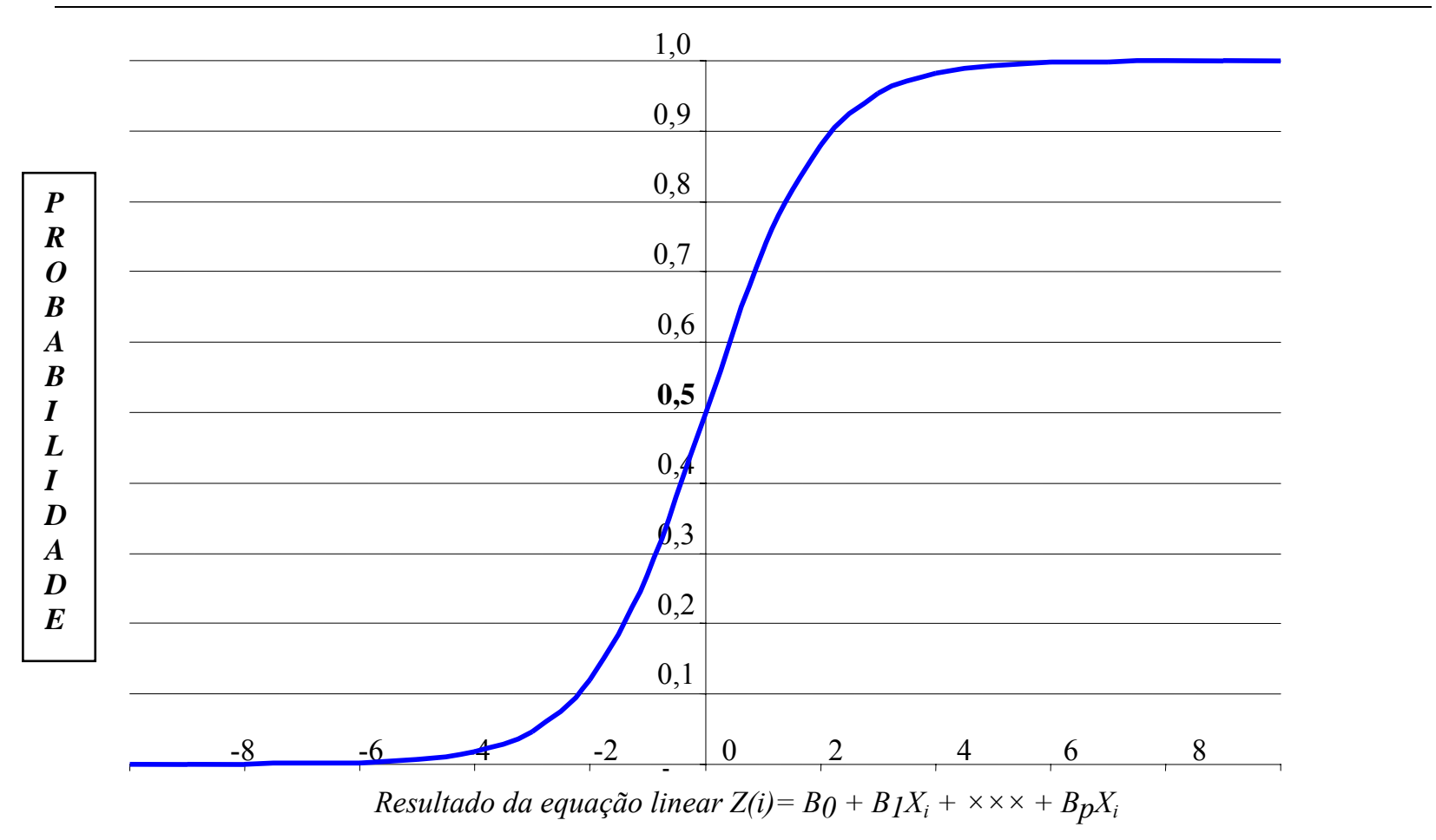

Figura 4 - Curva da regressão logística FONTE: HAIR et al., 1998, p. 277

Para verificar a capacidade de explicação e o grau de associação dos indicadores com as crises, os testes são realizados com três equações diferenciadas pelas variáveis independentes:

a) Utilizando os coeficientes de variação dos indicadores contábeis e de riscos, calculados 
com base nos desvios-padrão e nas médias dos quatro períodos anteriores à data-base do indicador, conforme a equação:

$$
\begin{aligned}
& P\left(1_{i}\right)=\frac{1}{1+e^{-\left(Z_{i}\right)}}, \text { onde: } \\
& Z_{i}=\beta_{0}+\beta_{1} \text { CATPL }_{i}+\beta_{2} \text { CALDT }_{i}+\beta_{3} \text { CCAOC }_{i}+\beta_{4} \text { CNOPPL }_{i}+\beta_{5} \text { CROE }_{i}+\ldots \\
& \ldots+\beta_{6} \text { CIRFX }_{i}+\beta_{7} \text { CIRTJ }_{i}+\beta_{8} \text { CIRCRE }_{i}+\beta_{9} \text { CIRLIQ }_{i}+\beta_{10} \text { CIRATPIB }_{i}
\end{aligned}
$$

onde:

CATPL é o indicador representativo do coeficiente de variação do ativo total sobre o patrimônio líquido.

CALDT é o indicador representativo do coeficiente de variação dos ativos líquidos sobre os depósitos totais.

CCAOC é o indicador representativo do coeficiente de variação dos créditos anormais sobre as operações de crédito.

CNOPPL é o indicador representativo do coeficiente de variação da posição líquida em moeda estrangeira sobre o patrimônio líquido.

CROE é o indicador representativo do coeficiente de variação da rentabilidade do patrimônio líquido.

CIRFX é o indicador representativo do coeficiente de variação do índice de risco da taxa de câmbio.

CIRTJ é o indicador representativo do coeficiente de variação do índice de risco da taxa de juros.

CIRCRE é o indicador representativo do coeficiente de variação do índice de risco de crédito. CIRLIQ é o indicador representativo do coeficiente de variação do índice de risco de liquidez. CIRATPIB é o indicador representativo do coeficiente de variação do índice de risco de variação do ativo total sobre o produto interno bruto.

b) Utilizando as médias dos indicadores contábeis e de riscos, calculados com base nos quatro períodos anteriores à data-base do indicador, conforme a equação: 
$P\left(1_{i}\right)=\frac{1}{1+e^{-\left(Z_{i}\right)}}$, onde:

$Z_{i}=\beta_{0}+\beta_{1} M_{A T P L}+\beta_{2} M A L D T_{i}+\beta_{3} M C A O C_{i}+\beta_{4} M N O P P L_{i}+\beta_{5} M R O E_{i}+\ldots$

$\ldots+\beta_{6}$ MIRFX $_{i}+\beta_{7}$ MIRTJ $_{i}+\beta_{8}$ MIRCRE $_{i}+\beta_{9}$ MIRLIQ $_{i}+\beta_{10}$ MIRATPIB $_{i}$

onde:

MATPL é o indicador representativo da média do ativo total sobre o patrimônio líquido.

MALDT é o indicador representativo da média dos ativos líquidos sobre os depósitos totais.

MCAOC é o indicador representativo da média dos créditos anormais sobre as operações de crédito.

MNOPPL é o indicador representativo da média da posição líquida em moeda estrangeira sobre o patrimônio líquido.

MROE é o indicador representativo da média da rentabilidade do patrimônio líquido.

MIRFX é o indicador representativo da média do índice de risco da taxa de câmbio.

MIRTJ é o indicador representativo da média do índice de risco da taxa de juros.

MIRCRE é o indicador representativo da média do índice de risco de crédito.

MIRLIQ é o indicador representativo da média do índice de risco de liquidez.

MIRATPIB é o indicador representativo da média do índice de risco de variação do ativo total sobre o produto interno bruto.

c) Utilizando os desvios-padrão dos indicadores contábeis e de riscos, calculados com base nos quatro períodos anteriores à data-base do indicador, conforme a equação:

$$
\begin{aligned}
& P\left(1_{i}\right)=\frac{1}{1+e^{-\left(Z_{i}\right)}}, \text { onde: } \\
& Z_{i}=\beta_{0}+\beta_{1} D_{A T P L_{i}}+\beta_{2} D A L D T_{i}+\beta_{3} D_{C A O C_{i}}+\beta_{4} D N O P P L_{i}+\beta_{5} D R O E_{i}+\ldots \\
& \ldots+\beta_{6} \text { DIRFX }_{i}+\beta_{7} \text { DIRTJ }_{i}+\beta_{8} \text { DIRCRE }_{i}+\beta_{9} \text { DIRLIQ }_{i}+\beta_{10} \text { DIRATPIB }_{i}
\end{aligned}
$$

onde: 
DATPL é o indicador representativo do desvio-padrão do ativo total sobre o patrimônio líquido.

DALDT é o indicador representativo do desvio-padrão dos ativos líquidos sobre os depósitos totais.

DCAOC é o indicador representativo do desvio-padrão dos créditos anormais sobre as operações de crédito.

DNOPPL é o indicador representativo do desvio-padrão da posição líquida em moeda estrangeira sobre o patrimônio líquido.

DROE é o indicador representativo do desvio-padrão da rentabilidade do patrimônio líquido.

DIRFX é o indicador representativo do desvio-padrão do índice de risco da taxa de câmbio.

DIRTJ é o indicador representativo do desvio-padrão do índice de risco da taxa de juros.

DIRCRE é o indicador representativo do desvio-padrão do índice de risco de crédito.

DIRLIQ é o indicador representativo do desvio-padrão do índice de risco de liquidez.

DIRATPIB é o indicador representativo do desvio-padrão do índice de risco de variação do ativo total sobre o produto interno bruto.

A expectativa é que todas as equações sejam estatisticamente significativas, capazes de mensurar o nível de risco sistêmico e indicar a probabilidade de ocorrência da crise com precisão satisfatória.

Todavia, é razoável admitir que alguns indicadores detenham maior conteúdo informacional que outros, sendo mais expressivos e robustos no processo de identificação de crises.

Da mesma forma, como subproduto, há esperança de que os resultados forneçam informações sobre o grau de relevância dos riscos individuais (crédito, taxa de juros, câmbio e liquidez), com base nos coeficientes encontrados.

Os indicadores calculados e submetidos aos testes estatísticos, com utilização do software estatístico SPSS, versão 10.0, encontram-se no Apêndice 3.

\subsubsection{Hipóteses das equações}

A verificação da capacidade de mensuração dos indicadores é feita pela utilização das seguintes hipóteses: 
H0: os indicadores contábeis e de riscos da equação não são capazes de classificar corretamente o sistema bancário de acordo com a suscetibilidade ou não à crise.

H1: os indicadores contábeis e de riscos da equação são capazes de classificar corretamente o sistema bancário de acordo com a suscetibilidade ou não à crise.

\subsection{Coleta e análise dos dados}

Consiste em coletar e analisar os dados necessários à pesquisa. As fontes são as bases de dados existentes no FMI, no BIRD, nos bancos centrais, nos órgãos de supervisão e em outras entidades privadas ${ }^{53}$.

Os dados referentes às variáveis econômicas são usualmente utilizados para avaliar os sistemas econômicos dos países-membros do IMF, sendo homogêneos e facilmente obtidos. Basicamente, são encontrados em endereços eletrônicos dos bancos centrais de países que compõem a amostra e em documentos elaborados pelo IMF (IMF, 2003).

Diferentemente, os dados contábeis de alguns países não são divulgados de forma padronizada, com diferenças na periodicidade e nos critérios contábeis adotados. Além disso, haja vista que alguns países adotam o regime de câmbio fixo, torna-se difícil a conversão da moeda para fins de comparação. Nessas situações, os dados precisam ser pesquisados, coletados e analisados individualmente, sendo necessário, inclusive, estabelecer contatos diretos com os órgãos de supervisão

Para evitar problemas e no intento de homogeneizar as informações, os indicadores selecionados são compostos por variáveis amplamente utilizadas nos processos de avaliação conduzidos por organismos internacionais (IMF e BIRD), onde os critérios são padronizados e conhecidos. Dessa forma, a expectativa é que as diferenças não invalidem os resultados.

53. O Bureau van Dick, dono da base de dados Bankscope, contém informações sobre mais de 24.000 bancos (em agosto de 2004) localizados em diversos países. Cada banco contém um relatório com 200 itens contábeis e 36 indicadores pré-calculados. 
Adicionalmente, com o auxílio da estatística descritiva é possível conhecer as medidas de tendência central e filtrar os dados anormais (outliers), omissos e errados.

Todas as fontes das variáveis contábeis e econômicas estão relacionadas no Apêndice 1, e nas planilhas de cálculo dos indicadores de cada país, no Apêndice 2.

\subsection{Análise dos resultados}

\subsubsection{Validação}

Conforme Hosmer e Lemeshow (1989, p. 13), a diretriz da regressão logística é a mesma da regressão linear, ou seja, "Comparar os valores observados da variável dependente com os valores resultantes do modelo, com e sem a variável que está sendo testada.",54

O processo é iterativo e consiste em incluir e excluir alternadamente variáveis ao modelo com o objetivo de encontrar a variável ou as variáveis que estão mais associadas à variável dependente.

A diferença é que a análise de regressão logística usa o critério da máxima verossimilhança para estimar os valores dos coeficientes que maximizam a probabilidade de obter o dado observado, definido como a variável dependente. Assim, testes específicos precisam ser aplicados para verificar a robustez estatística.

Os testes na regressão logística têm a finalidade de avaliar os modelos ou os indicadores. Os testes mais comumente encontrados nos pacotes estatísticos para avaliar os modelos são o Likelihood Value (Valor de Verossimilhança), o Cox e Snell $\mathrm{R}^{2}$, o Nagelkerke $\mathrm{R}^{2}$ e o Hosmer e Lemeshow. Quanto ao teste para avaliar os indicadores, o mais utilizado é o Teste Wald (SPSS, 2003).

Com vistas a possibilitar melhor compreensão sobre os resultados, faz-se interessante apresentar uma breve descrição da funcionalidade e interpretação de cada um dos testes.

54. Tradução livre de "Compare observed values of the response variable to predicted values obtained from models with and without the variable in question." 
a) Likelihood Value (Valor de Verossimilhança)

A finalidade do indicador é estimar a probabilidade associada à ocorrência de determinado evento (DIAS FILHO, 2003, p.201).

O teste consiste em calcular o logaritmo do valor da verossimilhança (log-likelihood) do modelo, por meio da seguinte fórmula:

$\log -$ likelihood $=L L=\sum_{i=1}^{N}\left[Y_{i} \ln \left(Y_{i}\right)+\left(1-\hat{Y}_{i}\right) \ln (1-\hat{Y})\right]$

onde o Y é o valor observado (0 ou 1) e o $\hat{Y}$ é a probabilidade predita pelo modelo. $\mathrm{O}$ somatório dos valores é o valor da verossimilhança utilizado na equação -2LL, com vistas a testar o resultado em uma distribuição do Qui-quadrado $\left(\chi^{2}\right)$.

Considerando que a probabilidade máxima é igual a um, o valor ótimo da equação é zero. Assim, quanto menor o valor da equação -2LL, maior o significado do modelo como um todo (HAIR et al., 1998, p.318).

b) Cox e Snell $R^{2}$ e Nagelkerke $R^{2}$

Os coeficientes $\mathrm{R}^{2}$ são semelhantes ao coeficiente de determinação na regressão linear. Quanto maiores os valores, melhores são os modelos (HAIR et al., 1998, p. 319).

A diferença entre os dois está na escala. Enquanto o Cox e Snell $\mathrm{R}^{2}$ não atinge o valor máximo de um, o Nagelkerke $\mathrm{R}^{2}$ foi modificado para apresentar resultados entre zero e um.

c) Hosmer e Lemeshow

Hosmer e Lemeshow (1989, p.140) apresentam um teste com base nas diferenças entre os valores das variáveis dependentes observadas e preditas pelo modelo. 
Utilizando a distribuição do Qui-quadrado, o método emprega uma tabela de contingência em que divide as observações por faixas. Em seguida, compara os valores observados com os estimados pelo modelo para cada faixa.

O objetivo é aceitar a hipótese de que não existem diferenças entre os valores observados e estimados, ou seja, quanto menor o valor do teste, menores as diferenças e melhor o modelo.

d) Teste de Wald

A finalidade do teste é verificar o grau de significância de cada coeficiente da equação logística. Similar ao teste "t", tem como finalidade testar se o coeficiente estimado é diferente de zero. Para tanto, utiliza a fórmula:

$$
\text { Wald }=\frac{\beta_{i}}{{\text { бerro } \beta_{i}}}
$$

onde o $\beta$ i é o coeficiente e oerro é o desvio-padrão do erro do coeficiente $\beta$ i. O resultado é igualmente verificado em uma distribuição Qui-quadrática.

A hipótese nula de coeficientes iguais a zero impõe restrição à utilização desses coeficientes nas equações resultantes, pois não são capazes de diferenciar as características isoladamente. Assim, busca-se rejeitar a hipótese nula com valores de $p$-value (sig.) inferiores ao nível de significância aceito $(5 \%)$.

\subsubsection{Interpretação}

A interpretação dos coeficientes dos indicadores que compõem a regressão logística deve ser realizada de forma quantitativa e qualitativa. A questão a responder, segundo Hosmer e Lemeshow (1989, p.38), é “O que os coeficientes estimados para as variáveis independentes no modelo contam sobre as questões da pesquisa que motivaram o estudo?" ${ }^{55}$.

No aspecto quantitativo, a finalidade é identificar o efeito resultante da variação no indicador,

55. Tradução livre de "What do the estimated coefficients in the model tell us about the research questions that motivated the study?". 
multiplicado pelo coeficiente, sobre a probabilidade de ocorrência do evento.

Conforme mencionado, os coeficientes são calculados com base no logaritmo natural da razão de chances (odds ratio) e as modificações nos indicadores provocam efeitos sobre essa relação. Assim, a variável dependente logaritmo natural da razão de chances é resultado da multiplicação do coeficiente $\beta$ pela variável independente $\mathrm{X}$. Caso o coeficiente seja igual a dois (2), a variável dependente sofrerá uma variação de duas unidades quando a variável independente $\mathrm{X}$ variar uma unidade, do mesmo modo que um modelo linear.

Contudo, essa informação não expressa qual é a variação percentual na probabilidade de ocorrer o evento, pois a relação é logística. Para conhecê-la, há necessidade de calcular o antilogaritmo do coeficiente $\left(\mathrm{e}^{\beta}\right)$, de acordo com o descrito em Gujarati (2000, p.565):

Em geral, se você pegar o antilog do j-ésimo coeficiente de inclinação, dele subtrair 1 e multiplicar por 100 , você terá a variação percentual na chance devido ao aumento de uma unidade no j-ésimo regressor.

Supondo, por exemplo, que o coeficiente $\beta$ do indicador $X$ seja igual a 0,05 , o antilogaritmo $\left(\mathrm{e}^{0,05}\right)$ é aproximadamente 1,0513 , e a chance de ocorrer o evento varia positivamente em $5,13 \%$ para o aumento de uma unidade de X.

Sob o enfoque qualitativo, a interpretação das equações validadas e dos respectivos indicadores significativos tem por objetivo identificar a contribuição desses na classificação dos sistemas bancários de cada país no grupo suscetível ou não-suscetível à crise.

Nesse sentido, o objeto de análise volta-se para o conteúdo informacional dos índices de risco sistêmico (IRS), obtidos pela submissão dos valores calculados para os indicadores de cada país às respectivas equações que melhor maximizam as classificações.

A associação das informações contidas nos IRS possibilita a elaboração de suposições sobre quais aspectos contábeis e econômicos merecem maior atenção para evitar novas crises. A expectativa é que os indicadores contábeis e de riscos contenham informações úteis à definição de medidas preventivas que busquem a redução de riscos no sistema bancário e na economia. 


\subsubsection{Avaliação das equações}

O critério de avaliação da equação é a maximização das porcentagens de acerto para as classificações nos grupos suscetível e não-suscetível à crise, de todos os países da amostra, observada a robustez estatística e a prioridade de erro estabelecida para o estudo.

A comparação entre o resultado predito pela equação e a realidade retorna uma das situações previstas na Tabela 9. A soma dos resultados obtidos em cada situação sobre o total possível informa o percentual de acertos e erros, por tipo, provenientes de cada equação testada.

Tabela 9 - Classificação dos resultados da aplicação dos modelos

\begin{tabular}{|l|l|l|}
\hline & H0 = Não-Crise & H1 = Crise \\
\hline Sinal =0 & "não-sinal bom” (A) & "não-sinal ruim” (B) - erro tipo I \\
\hline Sinal = & "sinal ruim" (C)- erro tipo II & "sinal bom” (D) \\
\hline
\end{tabular}

FONTE: Adaptado de Goldstein, Kaminsky e Reinhart, 2000, p.30.

No processo de classificação em grupos dicotômicos, da espécie "sim" ou "não", "presente" ou "ausente", "solvente" ou "insolvente", nos quais se insere a suscetibilidade ou não à crise, dois tipos de erros estatísticos são usuais, chamados de erros tipo I e tipo II (DOWNING; CLARK, 1998, p.48).

No caso, o erro tipo I é aquele no qual um país com experiência de crise é classificado no grupo não-suscetível à crise. Ou seja, ao classificar no grupo não-suscetível, rejeita-se a hipótese verdadeira de que o país pertença ao grupo suscetível à crise. O erro tipo II é o contrário e compreende a aceitação da hipótese quando ela é falsa. Isso ocorre ao classificar um país não-suscetível no grupo suscetível à crise.

Como as ações subseqüentes às classificações são distintas, visto que a qualificação de um país como suscetível à crise causa preocupação e exige a adoção de medidas imediatas, enquanto a classificação como não suscetível à crise tranqüiliza e dispensa maior atenção, as conseqüências dos erros são desiguais e precisam ser sopesadas no processo de avaliação.

Assim, com o objetivo de encontrar a equação que reduza a quantidade de erros tipo I, utilizase a seguinte fórmula de avaliação, conforme sugerida por Goldstein, Kaminsky e Reinhart (2000, p.32): 
$I A M=[B /(B+D)] /[A /(A+C)]$

onde:

IAM é o índice de avaliação do modelo, sendo interpretado na forma quanto menor, melhor; "A" representa a quantidade de eventos onde não houve crises e nem sinalização; "B" representa a quantidade de eventos onde houve crises e não houve sinalização; “C” representa a quantidade de eventos onde não houve crises e houve sinalização; " $D$ ” representa a quantidade de eventos onde houve crises e sinalização.

A equação com o menor valor de IAM é a que maximiza o percentual de acerto priorizado, sendo a mais adequada na classificação dos países nos grupos suscetíveis ou não à crise.

\subsubsection{Aplicação das equações}

A confirmação da robustez estatística dos resultados, bem como a identificação das equações que maximizam a classificação, observada a prioridade de reduzir o erro tipo I, possibilitam a aplicação das equações nos países da amostra para fins de obtenção da classificação geral nos grupos suscetível e não-suscetível à crise.

Adicionalmente, com vistas à generalização das equações, independentemente do tempo ou do país, as equações devem ser aplicadas sobre dados não utilizados na regressão logística. Assim, a proposta é verificar o desempenho das equações sobre os países da amostra com dados disponíveis em períodos diferentes.

Os resultados devem ser analisados à luz da realidade, mediante à comparação das sinalizações do nível de risco sistêmico apresentados pelos IRS com as experiências reais observadas em cada país. O conhecimento das crises ocorridas nos diversos países, inclusive as relatadas no referencial teórico, constituem a fonte de informação necessária para realizar a análise comparativa dos IRS.

A coincidência entre as datas das crises e as tendências apresentadas pelos IRS evidenciam a capacidade do instrumento em mensurar o risco sistêmico. Naturalmente, a expectativa é que os IRS apresentem maior nível de risco nos momentos em torno das crises. 


\section{ANÁLISE DOS RESULTADOS}

A validação quantitativa dos modelos e a identificação dos indicadores significativos possibilitam a interpretação qualitativa dos resultados para obtenção de respostas e conclusões ao estudo.

Faz-se importante reiterar que a elaboração dos indicadores buscou incorporar todos os principais aspectos observados em instituições bancárias pela estrutura de análise CAMELS. Os indicadores contábeis e de riscos, expostos no Apêndice 3, contemplam a adequação do capital frente ao volume de ativos (ATPL), a qualidade dos ativos (CAOC), o resultado (ROE), a liquidez (ALDT), a posição líquida em moeda estrangeira (NOPPL), os riscos de câmbio (IRFX), de taxa de juros (IRTJ), de crédito (IRCRE), de liquidez (IRLIQ), e, adicionalmente, a relação entre o volume de ativos financeiros e a produção interna bruta do país (ATPIB).

No entanto, os aspectos refletidos pelos indicadores não são necessariamente eqüitativos no processo de classificação dos países de acordo com a ocorrência ou não de crises. Enquanto alguns indicadores salientam-se e diferenciam as duas situações, outros são irrelevantes.

Nesse sentido, os testes prévios à análise de regressão propiciam indícios positivos ou negativos sobre a adequação de alguns indicadores, servindo de parâmetro ao entendimento dos motivos que os qualificam.

\subsection{Estatística descritiva}

O resultado da aplicação da estatística descritiva sobre os 30 indicadores (Anexo A), representativos da média, do desvio-padrão e do coeficiente de variação dos indicadores de quatro períodos anteriores às crises, para os países que compõem o grupo de crises, e de quatro anos de tranqüilidade, entre 1990 e 2002, para os países sem crises, contém informações sobre as medidas de tendência central, coeficientes de variação, máximos e mínimos dos indicadores. 
Conforme descrito na metodologia, o motivo da preocupação com a média, o desvio-padrão e os valores máximos e mínimos é o nível de dispersão dos indicadores. Indicadores mais dispersos em relação às médias dos grupos de crise e não-crise, ou centrados em torno da média geral, não possibilitam a identificação de características diferenciadas a cada grupo.

Apesar do coeficiente de variação médio ser igual a $1,15^{56}$, denotando equilíbrio na distribuição dos indicadores em torno das respectivas médias, alguns destoaram e apresentaram coeficiente de variação superior a dois, como os índices de liquidez, que relacionam o risco de variação dos depósitos totais sobre os ativos líquidos (CIRLIQ, MIRLIQ e DIRLIQ).

A elevada variabilidade dos indicadores de liquidez é explicada pela natureza temporal e ambiental característica da situação líquida. Conforme mencionado, a liquidez é altamente sensível a mudanças no sistema bancário e as informações disponíveis em demonstrações contábeis trimestrais não retratam plenamente o comportamento entre as datas. Dessa forma, alterações acentuadas a cada trimeste são absolutamente normais.

Em lugar da volatilidade inerente, o acompanhamento da liquidez deve ser concentrado na tendência ao longo do tempo, especialmente quando são observadas quedas sucessivas.

Além disso, a descrição das situações que antecedem as crises de alguns países da amostra expõe injeções de recursos no sistema pela autoridade monetária, tanto em espécie como em títulos públicos. Como esse procedimento não é homogêneo em todos os países e existem diferenças nos valores, há indícios de que os indicadores de liquidez possam ser ambíguos e não servir como discriminadores eficazes.

Com coeficientes de variação menores, mas também significativos, entre um e meio e dois, encontram-se os indicadores relativos aos créditos anormais sobre as operações de crédito (CCAOC, MCAOC e DCAOC), bem como os coeficientes de variação da rentabilidade (CROE), da posição líquida em moeda estrangeira (CNOPPL) e de risco da taxa de câmbio (CIRFX).

56. Demonstrado no anexo A. 
A variabilidade dos créditos anormais é devida às alterações na qualidade do crédito nos momentos que antecedem as crises e aos diferentes critérios usados para reconhecer e mensurar o valor do crédito anormal. A suposição é que os países com crise apresentem valores díspares e crescentes, em contraposição aos países sem crise, que devem apresentar regularidade no volume de créditos anormais.

Da mesma forma, a variabilidade dos coeficientes de variação da rentabilidade, da posição em moeda estrangeira e do risco de câmbio pode ser justificada tanto pela alternância de resultados e posições em câmbio, nos momentos que antecedem as crises, quanto por mudanças estratégicas e adaptações ao ambiente.

Novamente, o pressuposto é que os países sem crise apresentem resultados e posições em câmbio regulares, diferentemente dos países com crise que devem apresentar resultados irregulares, inclusive prejuízos, e posições instáveis em câmbio.

No lado oposto, com coeficiente de variação inferior ou próximo a um, estão os indicadores relacionados ao ativo sobre o patrimônio líquido (CATPL, MATPL e DATPL), ao risco de taxa de juros (CIRTJ, MIRTJ e DIRTJ) e ao risco da variação do ativo total em relação ao produto interno bruto (CIRATPIB, MIRATPIB e DIRATPIB).

Pela natureza desses indicadores, a variabilidade esperada não poderia ser elevada. Os indicadores de alavancagem do patrimônio líquido e da relação dos ativos financeiros em relação ao PIB não ultrapassam determinados limites mínimos e máximos para todo sistema bancário, assim como a taxa de juros praticada em cenários normais (sem hiperinflação).

A questão remanescente à análise dos aspectos apurados pela estatística descritiva é verificar se os indicadores, apesar do nível de dispersão, são ou não estatisticamente significativos para classificar os países.

Como a significância dos indicadores somente é obtida na análise de regressão logística, todas as suposições sobre os motivos da variabilidade são objeto de confirmação. Ou seja, não é possível saber previamente se o indicador com maior ou menor dispersão é capaz de discriminar os grupos de países com e sem crise. 
Quanto à delimitação mínima e máxima, o objetivo é verificar a existência de valores fora do intervalo correspondente a três desvios-padrão, denominados outliers ${ }^{57}$ (HAIR et al., 1998, p.65). Os indicadores que apresentaram valores abaixo ou acima dos intervalos mínimos e máximos previstos foram investigados e considerados corretos.

\subsection{Matriz de correlação}

A matriz de correlação é um instrumento que permite identificar comportamentos similares entre dois indicadores. Em técnicas que utilizam a regressão, a manutenção de indicadores perfeitamente correlacionados, de forma positiva ou negativa, traz conseqüências indesejáveis aos resultados.

Quando dois ou mais indicadores contribuem com as mesmas informações no modelo, a técnica estatística encontra dificuldades em separar o efeito independente de cada indicador e apurar a sua relevância específica.

Apesar de elevar o poder de explicação do modelo, expresso no coeficiente de determinação $\left(\mathrm{R}^{2}\right)$, a correlação torna o teste de significância (estatística " $t$ ”) não confiável.

Por esse motivo, os resultados apresentados pela matriz de correlação de cada grupo de indicadores representativos dos coeficientes de variação, média e desvio-padrão (Anexo B) devem ser observados na aplicação das demais técnicas.

Com vistas a evitar a discricionariedade na escolha do limite de correlação aceitável, usualmente estipulado em 0,7 (DOWNING; CLARK, 1998, p.354), optou-se pela utilização do teste de Correlação de Pearson, identificando-se aqueles com significância estatística ao nível de um e cinco por cento.

As Tabelas 10, 11 e 12 mostram os indicadores mais significativamente correlacionados, compreendendo os ativos líquidos sobre o depósito total (CALDT, MALDT e DALDT), o

57. Conforme HAIR et al. (1998, p.65), as observações distantes acima de 2,5 desvios-padrão da média, para amostras inferiores a 80 observações, são consideradas outliers. Para amostras maiores, o desvio-padrão varia entre 3 e 4. 
índice de risco da posição líquida em moeda estrangeira (CIRFX, MIRFX e DIRFX), o índice de risco de taxa de juros (CIRTJ, MIRTJ e DIRTJ), o índice de risco de crédito (MIRCRE e DIRCRE), os créditos anormais sobre operações de crédito (MCAOC e DCAOC), e o índice de risco do ativo total sobre o produto interno bruto (MIRATPIB e DIRATPIB).

Tabela 10 - Correlação de Pearson - coeficientes de variação

\begin{tabular}{|c|c|c|c|}
\hline INDICADOR & CIRFX & CIRTJ & CIRLIQ \\
\hline CATPL & 0,48 & 0,023 & $-0,139$ \\
\hline & $0,005^{*}$ & 0,899 & 0,447 \\
\hline CALDT & $-0,066$ & 0,565 & 0,656 \\
\hline & 0,72 & $0,001^{*}$ & $0^{*}$ \\
\hline CNOPPL & 0,605 & $-0,026$ & $-0,11$ \\
\hline & $0 *$ & 0,889 & 0,55 \\
\hline
\end{tabular}

* Correlação significativa ao nível de $1 \%$ (2-tailed)

FONTE: Próprio autor com base na saída do SPSS v.10.0

Tabela 11 - Correlação de Pearson - médias

\begin{tabular}{|c|c|c|c|c|c|}
\hline INDICADOR & MROE & MIRFX & MIRTJ & MIRCRE & MIRATPIB \\
\hline MATPL & 0,357 & 0,145 & $-0,202$ & $-0,038$ & 0,129 \\
\hline & $0,045^{* *}$ & 0,428 & 0,268 & 0,835 & 0,481 \\
\hline MALDT & $-0,402$ & $-0,082$ & 0,339 & 0,152 & 0,472 \\
\hline & $0,023^{* *}$ & 0,655 & 0,058 & 0,407 & $0,006^{*}$ \\
\hline MCAOC & $-0,393$ & $-0,274$ & 0,418 & 0,823 & $-0,031$ \\
\hline & $0,026^{* *}$ & 0,128 & $0,017 * *$ & $0 *$ & 0,866 \\
\hline MNOPPL & $-0,063$ & 0,786 & $-0,133$ & $-0,025$ & $-0,135$ \\
\hline & 0,732 & $0 *$ & 0,467 & 0,893 & 0,461 \\
\hline MROE & 1 & 0,052 & $-0,102$ & $-0,207$ & $-0,358$ \\
\hline & & 0,779 & 0,58 & 0,255 & $0,044 * *$ \\
\hline MIRTJ & & $-0,538$ & 1 & 0,512 & $-0,011$ \\
\hline & & $0,002^{*}$ & & $0,003^{*}$ & 0,95 \\
\hline MIRLIQ & & & & 0,393 & 0,075 \\
\hline & & & & $0,026^{* *}$ & 0,682 \\
\hline
\end{tabular}

* Correlação significativa ao nível de 1\% (2-tailed)

** Correlação significativa ao nível de 5\% (2-tailed)

FONTE: Próprio autor com base na saída do SPSS v.10.0

Tabela 12 - Correlação de Pearson - desvios-padrão

\begin{tabular}{|c|c|c|c|c|c|}
\hline INDICADOR & DROE & DIRFX & DIRTJ & DIRCRE & DIRATPIB \\
\hline DALDT & 0,43 & $-0,13$ & 0,05 & 0,09 & 0,37 \\
\hline & $0,014 * *$ & 0,47 & 0,79 & 0,64 & $0,038^{* *}$ \\
\hline DCAOC & 0,05 & 0,38 & 0,45 & 0,64 & $-0,18$ \\
\hline & 0,78 & $0,031^{* *}$ & $0,009 *$ & $0,09^{*}$ & 0,33 \\
\hline DIRTJ & 0,03 & 0,75 & 1,00 & 0,51 & 0,10 \\
\hline & 0,85 & $0 *$ &, & $0,003^{*}$ & 0,59 \\
\hline
\end{tabular}

* Correlação significativa ao nível de 1\% (2-tailed)

** Correlação significativa ao nível de 5\% (2-tailed)

FONTE: Próprio autor com base na saída do SPSS v.10.0 
Em decorrência da utilização das mesmas variáveis para a construção dos indicadores contábeis e de riscos, bem como a relação natural entre o risco e o retorno, a maior parte das correlações verificadas está alinhada com as expectativas traçadas para cada indicador e pode ser considerada normal.

Conforme esperado, houve a confirmação das correlações entre a posição líquida e o risco em moeda estrangeira (NOPPL e IRFX), o volume de ativos líquidos e o risco de liquidez (ALDT e IRLIQ), o volume de créditos anormais e o risco de crédito (CAOC e IRCRE), e o grau de alavancagem com a rentabilidade (ROE e ATPL).

Em adição, as fortes correlações negativas entre a rentabilidade e o volume de ativos líquidos e de créditos anormais são plenamente coerentes com as operações bancárias. A opção pela segurança da maior liquidez e o acréscimo de créditos não-realizáveis significam redução nos resultados e perda de rentabilidade.

Como informação diferenciada, aparece a significativa correlação negativa entre a rentabilidade e o indicador que relaciona os ativos financeiros com o PIB. Pode-se inferir que quanto maior a proporção de ativos financeiros em relação ao PIB, menor a rentabilidade do segmento bancário.

O entendimento sobre esse comportamento está na premissa de que o aumento dos ativos financeiros ocorre em títulos públicos e privados, e não em operações de crédito, direcionadas à produção. Dado que a rentabilidade dos títulos é menor do que a rentabilidade do crédito, a expansão desse tipo de ativo financeiro não é acompanhada pelo aumento de rentabilidade.

No que tange ao risco da taxa de juros, observa-se que o comportamento é altamente correlacionado com o volume de ativos líquidos e de créditos anormais, sendo, por conseqüência, também correlacionado com o risco de crédito. Depreende-se desse fato que o aumento na taxa de juros provoca o aumento no volume de créditos anormais, em face da maior dificuldade de pagamento. Os bancos, por sua vez, frente à redução do interesse pelo crédito majorado, direcionam os recursos para aplicações em ativos líquidos, geralmente compostos pelos títulos do governo indexados às taxas de juros. 
Além disso, a correlação negativa entre o risco da taxa de juros e o risco da taxa de câmbio evidencia que o aumento na taxa de juros é acompanhado pelo aumento do risco em moeda estrangeira, podendo ser resultante tanto da própria desvalorização da moeda do país frente à moeda estrangeira como pelo aumento real da posição líquida passiva em moeda estrangeira.

A explicação da correlação negativa deve ser creditada ao significado do sinal da posição líquida em moeda estrangeira. O sinal positivo indica uma posição líquida ativa, enquanto o sinal negativo uma posição líquida passiva.

Finalmente, a elevada correlação entre o desvio-padrão dos créditos anormais e o desviopadrão dos riscos da taxa de juros, de câmbio e de crédito demonstra que a volatilidade nas taxas de juros e de câmbio provoca variação no volume de créditos anormais. Assim, alterações nas taxas causam aumentos ou diminuições proporcionais no volume de créditos anormais.

O benefício de conhecer antecipadamente as correlações possibilita evitar problemas na aplicação da análise de regressão logística e a geração de resultados inconsistentes. Entretanto, a escolha definitiva de qual dos indicadores deve ser retirado ou mantido depende primordialmente do nível de significância que venha a apresentar na regressão logística.

\subsection{Análise fatorial}

A proposta da análise fatorial é reduzir a quantidade de indicadores, com base na correlação linear existente, em um conjunto de fatores não-correlacionados, ortogonais, de médias nulas, variâncias unitárias e capazes de explicar sinteticamente os indicadores originais.

Para tanto, a técnica identifica as associações lineares existentes entre os indicadores, verifica a capacidade de explicação da variância total do modelo pela variância de cada indicador (comunalidade ${ }^{58}$ ), extrai os fatores compiladores dos indicadores originais e evidencia aqueles mais relevantes em cada fator.

58. Segundo Malhotra (2001, p.505), "comunalidade” é a porção da variância que uma variável compartilha com todas as outras variáveis consideradas. É também a proporção de variância explicada pelos fatores comuns. 
Todavia, para considerar os fatores válidos e utilizáveis, o conjunto dos dados precisa apresentar medidas que satisfaçam os testes específicos KMO (Kaiser-Meyer-Olkin Measure of Sampling Adequacy) e Bartlett (Bartlett Test of Sphericity).

No caso, conforme demonstrado na Tabela 13, e também analiticamente no Anexo C, os testes são insatisfatórios, pois a medida que calcula a razão entre a correlação dos indicadores e a correlação dos indicadores mais a dos fatores (KMO) está abaixo de 0,5059 , cuja interpretação, segundo Pereira (2001, p.124), é que os dados não são apropriados à aplicação da análise fatorial.

Com base nesse resultado, apesar da existência de correlação entre os indicadores, expressa no teste de Bartlett, a análise fatorial não é capaz de construir fatores não-correlacionados, haja vista o valor insatisfatório do teste KMO.

Tabela 13 - Resultados da análise fatorial

\begin{tabular}{|l|c|c|c|c|}
\hline \multicolumn{1}{|c|}{ Indicadores } & Quantidade & \multirow{2}{*}{ KMO } & \multicolumn{2}{c|}{ Bartlett } \\
\cline { 4 - 5 } & & & Chi-quadrado & Significância \\
\hline Todos & 30 & 0,174 & 1145,741 & 0,000 \\
\hline Coeficiente de Variação & 10 & 0,404 & 81,917 & 0,001 \\
\hline Médias & 10 & 0,452 & 142,091 & 0,000 \\
\hline Desvios-padrão & 10 & 0,386 & 119,994 & 0,000 \\
\hline
\end{tabular}

FONTE: Próprio autor com base na saída do SPSS v.10.0

Em virtude da inviabilidade de utilizar fatores, a aplicação da análise de regressão logística foi mantida sobre os indicadores originais.

\subsection{Análise de regressão logística}

A análise quantitativa dos resultados da aplicação da regressão logística pode ser dividida de acordo com os indicadores submetidos aos testes. Considerando que os indicadores representam os coeficientes de variação, as médias e os desvios-padrão, os resultados correspondem a cada um dos grupos.

59. Ver também as explicações detalhadas referentes aos testes de Kaiser-Meyer-Olkin (KMO) e de Esfericidade de Bartlett (Bartlett) em Pereira (2001, p.124-125). 
Conforme descrito na metodologia, a variável dependente, com valores um e zero, indica a ocorrência de crise, ou não, nas observações da amostra (30 países e 32 situações). Os indicadores evidenciam aspectos contábeis e de risco nos sistemas bancários dos países da amostra e foram inseridos nos testes como variáveis independentes ou explicativas.

Os parâmetros da análise de regressão estabelecidos no SPSS v.10.0 foram os seguintes:

a) Método $E N T E R$, no qual ocorre a inclusão simultânea de todas as variáveis independentes.

b) Hosmer-Lemeshow goodness-of-fit, para avaliar se existem diferenças significativas entre as classificações do modelo e a realidade.

c) $C I$ for $\exp (B)$ igual a $95 \%$, para determinar o intervalo de confiança de cada coeficiente estimado.

d) Classification cut-off igual a 0,5, para estabelecer o ponto de corte da classificação.

e) Maximum iterations igual a 20, para limitar o número de vezes em que os testes são repetidos.

f) Include constant in model, para inserir a constante no modelo.

g) Classification plots, para visualizar a classificação graficamente.

Os quadros iniciais apresentados na saída do SPSS v.10.0 demonstram que todas as 32 observações foram tratadas, a variável dependente assumiu os valores zero e um, o percentual de acerto na classificação inicial, com base na proporção entre as situações de crise e nãocrise, é de $53,1 \%{ }^{60}$.

\subsubsection{Coeficientes de variação}

\subsubsection{Validação do modelo e significância de todos os indicadores}

Os resultados da regressão logística sobre os coeficientes de variação dos indicadores contábeis e de riscos demonstram que o modelo é válido de forma geral, mas não identifica indicadores significativos individualmente (Anexo D).

60. Inicialmente, a técnica atribui a classificação predominante (não-crise) a todas as observações. Como quinze observações das 32 são de crise $(46,9 \%)$, o percentual de acerto inicial, sem considerar as informações dos indicadores, é de $53,1 \%$. 
A apresentação detalhada dos resultados, iniciada na Tabela 14, mostra que a hipótese nula de coeficientes iguais a zero pode ser rejeitada, haja vista os resultados do teste dos coeficientes da equação.

$\mathrm{O}$ valor do Qui-quadrado $(44,236)$ corresponde à diferença entre o valor de $-2 \mathrm{LL}^{61}$, quando se inclui apenas a constante no modelo, e o $-2 \mathrm{LL}$ calculado com todas as variáveis independentes. Com dez graus de liberdade (df), a conclusão é que os coeficientes da regressão diferem de zero.

Tabela 14 - Teste da hipótese de coeficientes nulos - coeficientes de variação

\begin{tabular}{|ll|r|r|r|}
\hline & & Chi-square & \multicolumn{1}{|c|}{ df } & \multicolumn{1}{c|}{ Sig. } \\
\hline Step 1 & Step & 44,236 & 10 &, 000 \\
& Block & 44,236 & 10 &, 000 \\
& Model & 44,236 & 10 &, 000 \\
\hline
\end{tabular}

FONTE: Saída SPSS v.10.0

$\mathrm{Na}$ seqüência, são apresentadas outras estatísticas relativas ao desempenho do modelo. A Tabela 15 mostra que não há diferença entre os valores preditos e os valores realmente ocorridos, pois o valor de -2LL é igual a zero, bem como os elevadíssimos valores dos coeficientes $\mathrm{R}^{2}$ de Cox \& Snell e Nagelkerke indicam que o modelo tem elevado poder para explicar a variância da variável dependente.

Tabela 15 - Resumo do modelo - coeficientes de variação

\begin{tabular}{|l|r|r|r|}
\hline Step & $\begin{array}{c}-2 \text { Log } \\
\text { likelihood }\end{array}$ & $\begin{array}{c}\text { Cox \& Snell } \\
\text { R Square }\end{array}$ & $\begin{array}{c}\text { Nagelkerke } \\
\text { R Square }\end{array}$ \\
\hline 1 &, 000 &, 749 & 1,000 \\
\hline
\end{tabular}

FONTE: Saída SPSS v.10.0

Igualmente, o resultado do teste de Hosmer e Lemeshow, exposto na Tabela 16, confirma que não há diferenças entre os valores das variáveis dependentes observadas e preditas pelo modelo.

61. Duas vezes o logaritmo natural do valor da verossimilhança. Fórmula 33 detalhada na seção 3.5.1. 
Tabela 16 - Teste de Hosmer e Lemeshow - coeficientes de variação

\begin{tabular}{|l|r|r|r|}
\hline Step & Chi-square & df & Sig. \\
\hline 1 &, 000 & & 6 \\
\hline
\end{tabular}

FONTE: Saída SPSS v.10.0

Frente a resultados tão expressivos, $100 \%$ das observações foram classificadas corretamente, conforme a Tabela 17.

Tabela 17 - Tabela de classificação - coeficientes de variação

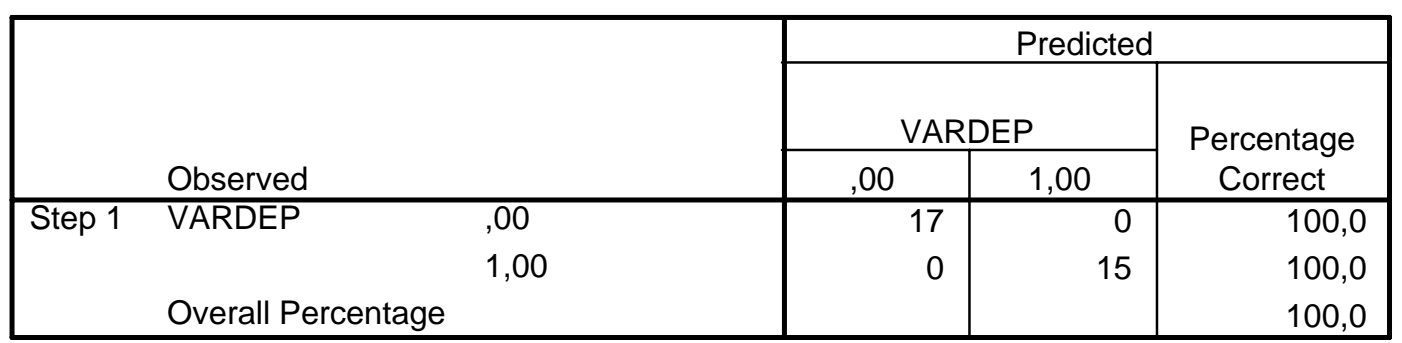

FONTE: Saída SPSS v.10.0

Contudo, os excelentes resultados de validação do modelo não foram correspondidos no teste de Wald, cuja finalidade é aferir o grau de significância de cada coeficiente, mediante a divisão entre o coeficiente (B) encontrado e o desvio-padrão (S.E.). A Tabela 18 revela que os indicadores não apresentam significância ao nível de 5\% ou 10\% individualmente.

Tabela 18 - Indicadores na equação - coeficientes de variação

\begin{tabular}{|c|c|c|c|c|c|c|c|c|c|}
\hline & & \multirow[b]{2}{*}{ B } & \multirow[b]{2}{*}{ S.E. } & \multirow[b]{2}{*}{ Wald } & \multirow[b]{2}{*}{$\mathrm{df}$} & \multirow[b]{2}{*}{ Sig. } & \multirow[b]{2}{*}{$\operatorname{Exp}(B)$} & \multicolumn{2}{|c|}{ 95,0\% C.I.for EXP(B) } \\
\hline & & & & & & & & Lower & Upper \\
\hline$a$ & CATPL & 2,663 & 96,806 & ,001 & 1 & 978 & 14,342 &, 000 & $3,6 \mathrm{E}+83$ \\
\hline & CALDT & 2,057 & 44,077 & ,002 & 1 & ,963 & 7,823 & ,000 & $3, E+38$ \\
\hline & CCAOC & ,038 & 7,225 & ,000 & 1 & ,996 & 1,039 & ,000 & $1, E+06$ \\
\hline & CNOPPL &,- 583 & 12,347 & ,002 & 1 & ,962 & ,558 & ,000 & $2, E+10$ \\
\hline & CROE & ,230 & 5,066 &, 002 & 1 & ,964 & 1,259 &, 000 & 25842,6 \\
\hline & CIRFX & 194 & 5,057 & ,001 & 1 & ,969 & 1,214 & ,000 & 24448,3 \\
\hline & CIRTJ &,- 007 & 13,288 & ,000 & 1 & 1,000 & ,993 & ,000 & $2, E+11$ \\
\hline & CIRCRE &,- 253 & 19,361 & ,000 & 1 & ,990 & ,777 & ,000 & $2, E+16$ \\
\hline & CIRLIQ &,- 371 & 8,363 & ,002 & 1 & ,965 & 690 & ,000 & $9, E+06$ \\
\hline & CIRATPIB & $-2,886$ & 80,666 & ,001 & 1 & ,971 & ,056 & ,000 & $2,6 E+67$ \\
\hline & Constant & 7,224 & 5113,1 &, 000 & 1 & ,999 & 1371,4 & & \\
\hline
\end{tabular}

a. Variable(s) entered on step 1: CATPL, CALDT, CCAOC, CNOPPL, CROE, CIRFX, CIRTJ, CIRCRE, CIRLIQ, CIRATPIB.

FONTE: Saída SPSS v.10.0 
A forte correlação existente entre alguns indicadores, verificada na matriz de correlação, leva à suspeição dos resultados e consiste na principal justificativa para a falta de identificação dos indicadores com maior poder de explicação da variância da variável dependente, ou seja, de classificar como suscetível, ou não, à crise.

Em busca da solução, os testes foram repetidos com a exclusão dos indicadores com elevada correlação. A escolha de qual dos indicadores correlacionados deve ser retirado é feita com base na significância, ou seja, aqueles com menor "score" e maior "sig." na Tabela 19.

Tabela 19 - Significância dos indicadores fora da equação- coeficientes de variação

\begin{tabular}{|c|c|c|c|c|c|}
\hline & & & Score & df & Sig. \\
\hline \multirow{10}{*}{$\begin{array}{l}\text { Step } \\
0\end{array}$} & Variables & CATPL & 2,510 & 1 & 113 \\
\hline & & CALDT & ,748 & 1 & ,387 \\
\hline & & CCAOC & 1,761 & 1 & 185 \\
\hline & & CNOPPL & ,706 & 1 & ,401 \\
\hline & & CROE & 5,676 & 1 & ,017 \\
\hline & & CIRFX & ,353 & 1 &, 552 \\
\hline & & CIRTJ & 2,193 & 1 & 139 \\
\hline & & CIRCRE & ,182 & 1 & ,669 \\
\hline & & CIRLIQ & ,212 & 1 & 645 \\
\hline & & CIRATPIB & 667 & 1 & ,414 \\
\hline & Overall S & & 17,314 & 10 & ,068 \\
\hline
\end{tabular}

FONTE: Saída SPSS v.10.0

Após a exclusão dos dois indicadores mais correlacionados, representativos dos coeficientes de variação do índice de risco de câmbio e dos ativos líquidos sobre os depósitos totais (CIRFX e o CALDT), os testes de validação do modelo pioraram, mas ainda permaneceram satisfatórios. O percentual de classificação correta reduziu para 93,8\% e apenas dois indicadores, correspondentes aos coeficientes de variação da rentabilidade e da alavancagem (CROE e CATPL), apresentaram significância no teste de Wald, ao nível de 5\% e 10\%, respectivamente.

$\mathrm{Na}$ tentativa de obter um modelo utilizável, foram mantidos apenas os indicadores com melhor significância no teste de Wald, identificados com valor superior a um na Tabela 20. 
Tabela 20 - Significância dos indicadores - oito coeficientes de variação

\begin{tabular}{|c|c|c|c|c|c|c|c|c|c|}
\hline & \multirow[b]{2}{*}{ B } & \multirow[b]{2}{*}{ S.E. } & \multirow[b]{2}{*}{ Wald } & \multirow[b]{2}{*}{ df } & \multirow[b]{2}{*}{ Sig. } & \multirow[b]{2}{*}{$\operatorname{Exp}(B)$} & \multicolumn{2}{|c|}{$95,0 \%$ C.I.for EXP(B) } \\
\hline & & & & & & & & Lower & Upper \\
\hline \multirow[t]{9}{*}{$\mathrm{a}$} & CATPL & ,068 &, 041 & 2,843 & 1 & ,092 & 1,071 & 989 & 1,160 \\
\hline & CCAOC &,- 001 & ,002 & ,468 & 1 & ,494 & ,999 & ,994 & 1,003 \\
\hline & CNOPPL &,- 003 & ,003 & 1,189 & 1 & ,276 & ,997 & ,992 & 1,002 \\
\hline & CROE & ,003 & ,002 & 4,114 & 1 & 043 & 1,003 & 1,000 & 1,007 \\
\hline & CIRTJ & ,007 & ,006 & 1,555 & 1 & ,212 & 1,007 & ,996 & 1,019 \\
\hline & CIRCRE &,- 001 & ,006 & ,032 & 1 & ,858 & ,999 & ,987 & 1,011 \\
\hline & CIRLIQ & ,000 & ,001 & ,213 & 1 & ,644 & 1,000 & ,998 & 1,001 \\
\hline & CIRATPIB &,- 013 & ,017 & ,635 & 1 & ,426 & 987 & ,955 & 1,020 \\
\hline & Constant & $-5,718$ & 3,568 & 2,569 & 1 & 109 & ,003 & & \\
\hline
\end{tabular}

a. Variable(s) entered on step 1: CATPL, CCAOC, CNOPPL, CROE, CIRTJ, CIRCRE, CIRLIQ, CIRATPI FONTE: Saída SPSS v.10.0

Em relação ao teste anterior, os resultados melhoraram, com os indicadores representativos dos coeficientes de variação da alavancagem e do índice de risco da taxa de juros (CATPL e CIRTJ) significativos ao nível de $10 \%$, e o coeficiente de variação da rentabilidade (CROE) significativo ao nível de 5\%. Somente o coeficiente de variação da posição líquida em moeda estrangeira (CNOPPL) não apresentou significância.

Em novo teste, sem o CNOPPL, repetiram-se os bons resultados para o modelo e o percentual de acerto manteve-se em 90,6\%. Contudo, mais uma vez, um dos indicadores não apresentou significância ao nível de 10\%, sendo necessária também a exclusão do CATPL.

Finalmente, conforme demonstrado na Tabela 21, os resultados dos testes de validação do modelo utilizando apenas os indicadores CROE e CIRTJ, em detalhes no Anexo G, são satisfatórios e o percentual de acerto na classificação é de 84,4\%.

Tabela 21 - Resumo dos testes de validação do modelo - CROE e CIRTJ

\begin{tabular}{|l|c|c|c|c|c|c|c|c|}
\hline Teste & Step & Block & Model & H\&L & $-2 \mathrm{LL}$ & Cox\&Snell & Nagelkerke & Acerto \\
\hline Medida & \multicolumn{7}{|c|}{ Qui-quadrado } & \multicolumn{3}{|c|}{$\mathrm{R}^{2}$} & $\%$ \\
\hline Valores & 23,610 & 23,610 & 23,610 & 8,214 & 20,626 & 0,522 & 0,697 & 84,4 \\
\hline Significância & 0,000 & 0,000 & 0,000 & 0,413 & & & & \\
\hline
\end{tabular}

FONTE: Próprio autor com base na saída do SPSS v.10.0

Destarte, a Tabela 22 evidencia que os indicadores apresentam significância estatística no teste de Wald, ao nível de 5\%, para o CROE, e 10,5\%, para o CIRTJ. 
Em adição, o intervalo de confiança estipulado em 95\% (CI for exp(B)) fixa os limites mínimos e máximos nos quais o indicador deve se encontrar para ser significativo. No caso, a constante " $e$ " (igual a 2,71828) elevada aos valores dos coeficientes $B$ dos indicadores CROE e CIRTJ $(0,003$ e 0,004) resulta nos valores 1,003 e 1,004, os quais se encontram nos intervalos de confiança $[1,000: 1,005]$ e $[0,999: 1,009]$, respectivamente.

Tabela 22 - Significância dos indicadores - CROE e CIRTJ

\begin{tabular}{|c|c|c|c|c|c|c|c|c|c|}
\hline & & \multirow[b]{2}{*}{ B } & \multirow[b]{2}{*}{ S.E. } & \multirow[b]{2}{*}{ Wald } & \multirow[b]{2}{*}{$\mathrm{df}$} & \multirow[b]{2}{*}{ Sig. } & \multirow[b]{2}{*}{$\operatorname{Exp}(B)$} & \multicolumn{2}{|c|}{ 95,0\% C.I.for EXP(B) } \\
\hline & & & & & & & & Lower & Upper \\
\hline \multirow[t]{3}{*}{$\mathrm{a}$} & CROE & ,003 & ,001 & 5,348 & 1 & ,021 & 1,003 & 1,000 & 1,005 \\
\hline & CIRTJ & ,004 & ,003 & 2,626 & 1 & ,105 & 1,004 & ,999 & 1,009 \\
\hline & Constant & $-3,812$ & 1,506 & 6,406 & 1 & 011 & 022 & & \\
\hline
\end{tabular}

a. Variable(s) entered on step 1: CROE, CIRTJ.

FONTE: Saída SPSS v.10.0

\subsubsection{Validação do modelo e significância dos indicadores contábeis}

Alternativamente ao teste com todos os coeficientes de variação, aplicou-se a técnica apenas no conjunto dos coeficientes de variação dos indicadores contábeis. Os resultados foram semelhantes ao do conjunto completo, com validação do modelo e percentual elevado de acerto na classificação, assim como a dificuldade de encontrar indicadores significativos.

Conforme pode ser verificado na Tabela 23, apenas os indicadores CATPL e CROE apresentam significância ao nível de $10 \%$ e 5\%, respectivamente.

Tabela 23 - Significância dos indicadores contábeis

\begin{tabular}{|c|c|c|c|c|c|c|c|c|c|}
\hline & \multirow[b]{2}{*}{ B } & \multirow[b]{2}{*}{ S.E. } & \multirow[b]{2}{*}{ Wald } & \multirow[b]{2}{*}{$\mathrm{df}$} & \multirow[b]{2}{*}{ Sig. } & \multirow[b]{2}{*}{$\operatorname{Exp}(B)$} & \multicolumn{2}{|c|}{ 95,0\% C.I.for EXP(B) } \\
\hline & & & & & & & & Lower & Upper \\
\hline \multirow[t]{6}{*}{$\mathrm{a}$} & CATPL & ,056 & ,030 & 3,380 & 1 & ,066 & 1,057 & ,996 & 1,122 \\
\hline & CALDT & ,003 & ,002 & 1,638 & 1 & ,201 & 1,003 & ,999 & 1,007 \\
\hline & CCAOC &,- 002 & ,002 & 1,082 & 1 & ,298 & ,998 & ,994 & 1,002 \\
\hline & CNOPPL &,- 002 & ,002 & ,929 & 1 & ,335 & ,998 & ,994 & 1,002 \\
\hline & CROE & ,003 & ,001 & 4,557 & 1 & ,033 & 1,003 & 1,000 & 1,006 \\
\hline & Constant & $-4,587$ & 2,14 & 4,586 & 1 & ,032 & ,010 & & \\
\hline
\end{tabular}

a. Variable(s) entered on step 1: CATPL, CALDT, CCAOC, CNOPPL, CROE.

FONTE: Saída SPSS v.10.0 
Da mesma forma realizada para todos os coeficientes, os indicadores não significativos para o modelo foram excluídos. Os resultados com apenas dois indicadores, CATPL e CROE, mantêm-se satisfatórios para o modelo, mas o indicador CATPL não apresenta significância ao nível de $10 \%$.

\subsubsection{Validação do modelo e significância dos indicadores de riscos}

$\mathrm{O}$ teste com os indicadores de riscos repetiu os resultados anteriores. Apenas o indicador CIRTJ apresenta significância ao nível de 5\%. Entretanto, o resultado do teste com esse indicador não apresenta bom nível de acerto na classificação, alcançando somente 59\%.

Isso evidencia que os resultados dos testes realizados utilizando todos os coeficientes de variação simultaneamente são melhores.

\subsubsection{Modelo com utilização de indicadores representativos dos coeficientes de variação}

Validado o modelo de classificação e identificados os indicadores representativos dos coeficientes de variação significativos, o modelo de classificação dos países suscetíveis ou não a crises pode ser representado pela seguinte equação linear:

$Z_{i}=-3,812+0,003 * \operatorname{CROE}_{i}+0,004 * \operatorname{CIRTJ}_{i}$

Onde:

CROE é o coeficiente de rentabilidade do patrimônio líquido; e

CIRTJ é o índice de risco da taxa de juros.

Entretanto, como a equação linear é parte da função logística, a probabilidade de ocorrência ou não de crise é calculada pela equação:

$$
P\left(\text { crise }_{i}\right)=\frac{1}{1+e^{-\left(-3,812+0,003^{*} C R O E_{i}+0,004^{*} C I R T J_{i}\right)}}
$$


No tocante aos coeficientes dos indicadores CROE e CIRTJ, estão coerentes com o comportamento do risco sistêmico. Quanto maior o coeficiente de variação da rentabilidade e do risco da taxa de juros, maior é o risco sistêmico.

A grandeza dos valores, entretanto, é muito inferior ao valor da constante, ensejando dificuldades na interpretação dos resultados.

\subsubsection{Médias}

\subsubsection{Validação do modelo e significância dos indicadores}

Os resultados da regressão logística sobre as médias dos indicadores contábeis e de riscos demonstram que o modelo é igualmente válido, mas também não identifica indicadores significativos individualmente (Anexo E).

A Tabela 24 contém o resumo dos testes de validação do modelo. O teste dos coeficientes da equação revela que a hipótese de coeficientes nulos pode ser rejeitada.

Os teste de Hosmer e Lemeshow (H\&L) e -2LL demonstram que não há diferenças entre os valores preditos pelo modelo e os valores observados na realidade, pois ambos são iguais a zero.

No mesmo sentido, os coeficientes $\mathrm{R}^{2}$ de Cox \& Snell e Nagelkerke corroboram a capacidade explicativa do modelo, refletida no percentual de acerto em $100 \%$.

Tabela 24 - Resumo dos testes de validação do modelo - indicadores representativos das médias

\begin{tabular}{|l|c|c|c|c|c|c|c|c|}
\hline Teste & Step & Block & Model & H\&L & -2LL & Cox\&Snell & Nagelkerke & Acerto \\
\hline Medida & \multicolumn{7}{|c|}{ Qui-quadrado } & \multicolumn{3}{|c|}{$\mathrm{R}^{2}$} & $\%$ \\
\hline Valores & 44,236 & 44,236 & 44,236 & 0,000 & 0,000 & 0,749 & 1,000 & 100,0 \\
\hline Significância & 0,000 & 0,000 & 0,000 & 1,000 & & & & \\
\hline
\end{tabular}

FONTE: Próprio autor com base na saída do SPSS v.10.0

Novamente, como nos testes com os coeficientes de variação, o teste de Wald apresentado na Tabela 25 informa que os indicadores não apresentam significância individualmente. A 
reincidente causa é a elevada correlação verificada entre os indicadores, capaz de gerar tais resultados espúrios à regressão.

Tabela 25 - Indicadores na equação - médias

\begin{tabular}{|c|c|c|c|c|c|c|c|c|}
\hline & \multirow[b]{2}{*}{ B } & \multirow[b]{2}{*}{ S.E. } & \multirow[b]{2}{*}{ Wald } & \multirow[b]{2}{*}{ df } & \multirow[b]{2}{*}{ Sig. } & \multirow[b]{2}{*}{$\operatorname{Exp}(B)$} & \multicolumn{2}{|c|}{ 95,0\% C.I.for EXP(B) } \\
\hline & & & & & & & Lower & Upper \\
\hline $\begin{array}{ll}\text { a } & \text { MATPL }\end{array}$ &, 000 & 800 &, 000 & $\overline{1}$ & 1,000 & 1,000 & ,208 & 4,798 \\
\hline MALDT &,- 057 & 23,57 & 000 & 1 & 998 & ,945 & ,000 & $1,1 \mathrm{E}+20$ \\
\hline MCAOC & 433 & 235,1 & ,000 & 1 & 999 & 1,541 & ,000 & $2,16+200$ \\
\hline MNOPPL &,- 007 & 34,42 & ,000 & 1 & 1,000 & 993 & ,000 & $2,0 E+29$ \\
\hline MROE &,- 056 & 168,1 & ,000 & 1 & 1,000 & ,945 & 000 & $1,18+143$ \\
\hline MIRFX & ,005 & 13,19 & ,000 & 1 & 1,000 & 1,005 & 000 & $1,7 \mathrm{E}+11$ \\
\hline MIRTJ & ,004 & 3,861 & ,000 & 1 & 1,000 & 1,004 & ,001 & 1940,202 \\
\hline MIRCRE & ,053 & 84,00 & ,000 & 1 & 1,000 & 1,054 & ,000 & $3,35 E+71$ \\
\hline MIRLIQ & -, 004 & 2,521 & ,000 & 1 & 999 & 996 & ,007 & 139,405 \\
\hline MIRATPIB & ,006 & 2,583 & ,000 & 1 & 998 & 1,006 & 006 & 159,121 \\
\hline Constant & $-34,04$ & **** & ,000 & 1 & 1,000 & ,000 & & \\
\hline
\end{tabular}

a. Variable(s) entered on step 1: MATPL, MALDT, MCAOC, MNOPPL, MROE, MIRFX, MIRTJ, MIRCRE, MIRLIQ, MIRATPIB.

FONTE: Saída SPSS v.10.0

Com vistas à obtenção de resultados com indicadores significativos, eliminaram-se os indicadores mais correlacionados. A escolha foi feita de forma análoga aos coeficientes de variação, com exclusão daqueles com menor "score" e maior "sig." na Tabela 26.

Tabela 26 - Significância dos indicadores fora da equação- médias

\begin{tabular}{|lll|r|r|r|}
\hline & & \multicolumn{1}{c|}{ Score } & df & \multicolumn{1}{c|}{ Sig. } \\
\hline Step & Variables & MATPL & 5,945 & 1 &, 015 \\
& MALDT &, 743 & 1 &, 389 \\
& MCAOC & 12,457 & 1 &, 000 \\
& MNOPPL &, 033 & 1 &, 857 \\
& MROE & 7,551 & 1 &, 006 \\
& MIRFX & 3,295 & 1 &, 069 \\
& MIRTJ & 11,863 & 1 &, 001 \\
& MIRCRE & 8,614 & 1 &, 003 \\
& MIRLIQ &, 865 & 1 &, 352 \\
& MIRATPIB &, 860 & 1 &, 354 \\
& & 23,224 & 10 &, 010 \\
\hline
\end{tabular}

FONTE: Saída SPSS v.10.0 
Um aspecto a ser ressaltado em relação aos coeficientes de variação é a maior quantidade de indicadores significativos. Enquanto somente um indicador apresentou relevância (CROE) no conjunto dos coeficientes de variação, seis indicadores representativos das médias têm significância ao nível de 5\% e $10 \%$.

Por esse motivo, apenas os indicadores representativos das médias dos ativos líquidos sobre os depósitos totais (MALDT), da posição líquida em moeda estrangeira sobre o patrimônio líquido (MNOPPL), do índice de risco de liquidez (MIRLIQ), e do índice de risco do ativo total sobre o PIB (MIRATPIB) foram eliminados. Os demais, observadas as correlações, foram testados dois a dois, haja vista que as tentativas de incluir um terceiro indicador resulta sempre na invalidação de todos pelo teste de Wald.

Tabela 27 - Comparação dos resultados dos pares de indicadores significativos - médias

\begin{tabular}{|l|c|c|c|c|c|c|c|c|c|}
\hline \multirow{2}{*}{$\begin{array}{l}\text { Indicadores } \\
\text { testados }\end{array}$} & \multicolumn{3}{|c|}{ MROE-MIRCRE } & \multicolumn{3}{c|}{ MROE-MIRFX } & \multicolumn{3}{c|}{ MROE-MIRTJ } \\
\cline { 2 - 10 } & $\mathrm{B}$ & Wald & Sig. & B & Wald & Sig. & B & Wald & Sig. \\
\hline MROE & $-0,032$ & 5,257 & 0,022 & $-0,019$ & 6,319 & 0,012 & $-0,038$ & 5,420 & 0,020 \\
\hline MIRCRE & 0,042 & 5,318 & 0,021 & & & & & & \\
\hline MIRFX & & & & 0,000 & 3,513 & 0,061 & & & \\
\hline MIRTJ & & & & & & & 0,001 & 5,759 & 0,016 \\
\hline Constante & $-2,147$ & 2,179 & 0,140 & 0,273 & 0,166 & 0,684 & $-2,106$ & 2,527 & 0,112 \\
\hline
\end{tabular}

\begin{tabular}{|l|c|c|c|c|c|c|c|c|c|}
\hline \multirow{2}{*}{$\begin{array}{l}\text { Indicador } \\
\text { testado }\end{array}$} & \multicolumn{3}{|c|}{ MATPL-MCAOC } & \multicolumn{3}{c|}{ MATPL-MIRFX } & \multicolumn{3}{c|}{ MATPL-MIRTJ } \\
\cline { 2 - 10 } \\
\cline { 2 - 10 } \\
MATPL & $-0,003$ & Wald & Sig. & B & Wald & Sig. & B & Wald & Sig. \\
\hline MCAOC & 2,320 & 0,000 & 0,996 & 0,000 & 4,533 & 0,033 & 0,000 & 3,846 & 0,05 \\
\hline MIRFX & & & & 0,000 & 2,500 & 0,114 & & & \\
\hline MIRTJ & & & & & & & 0,000 & 6,968 & 0,008 \\
\hline Constante & $-19,01$ & & 0,998 & 1,855 & 2,104 & 0,147 & 0,260 & 0,027 & 0,869 \\
\hline
\end{tabular}

\begin{tabular}{|l|c|c|c|c|c|c|c|c|c|}
\hline \multirow{2}{*}{$\begin{array}{l}\text { Indicador } \\
\text { testado }\end{array}$} & \multicolumn{3}{|c|}{ MATPL-MIRCRE } & \multicolumn{3}{c|}{ MIRFX-MCAOC } & \multicolumn{3}{c|}{ MIRFX-MIRCRE } \\
\cline { 2 - 10 } & B & Wald & Sig. & B & Wald & Sig. & B & Wald & Sig. \\
\hline MATPL & 0,000 & 5,073 & 0,024 & & & & & & \\
\hline MIRCRE & 0,044 & 5,880 & 0,015 & & & & 0,028 & 6,170 & 0,013 \\
\hline MIRFX & & & & $-0,002$ & 0,000 & 0,996 & 0,000 & 0,367 & 0,545 \\
\hline MCAOC & & & & 2,372 & 0,000 & 0,987 & & & \\
\hline Constante & $-0,135$ & 0,006 & 0,940 & $-61,826$ & 0,000 & 0,987 & $-3,309$ & 8,305 & 0,004 \\
\hline
\end{tabular}

FONTE: Próprio autor com base na saída do SPSS v.10.0

A Tabela 27 exibe os resultados dos testes sobre os pares de indicadores representativos das médias da alavancagem e dos créditos anormais (MATPL e MCAOC), da alavancagem e do índice de risco de câmbio (MATPL e MIRFX), da alavancagem e do índice de risco da taxa de juros (MATPL e MIRTJ), da alavancagem e do índice de risco de crédito (MATPL e MIRCRE), dos créditos anormais e do índice de risco de câmbio (MCAOC e MIRFX), da 
rentabilidade e do índice de risco de câmbio (MROE e MIRFX), da rentabilidade e do índice de risco da taxa de juros (MROE e MIRTJ), da rentabilidade e do índice de risco de crédito (MROE E MIRCRE), e dos índices de risco de câmbio e de crédito (MIRFX e MIRCRE).

Os resultados revelam que os indicadores com significância estatística, ao nível de $5 \%$, são os pares formados pelas médias da rentabilidade e do índice de risco de crédito (MROE e MIRCRE), e da rentabilidade e do índice de risco da taxa de juros (MROE e MIRTJ), com os detalhes dos resultados da regressão expostos nos Anexos H e I. Mesmo assim, para usá-los no modelo de classificação, há necessidade de relaxar a exigência para a significância da constante.

Em relação à validação dos modelos, ambos são satisfatórios, com bom percentual de acerto na classificação. A Tabela 28 evidencia que o modelo formado pelos indicadores MROE e MIRCRE apresenta menor diferença entre os valores preditos e observados e maior poder de explicação da variável dependente, culminando em maior percentual de acerto.

Tabela 28 - Resumo dos testes de validação dos modelos - médias

\begin{tabular}{|l|c|c|c|c|c|}
\hline Teste & -2LL & H\&L & Cox\&Snell & Nagelkerke & Acerto \\
\hline Medida & \multicolumn{2}{|c|}{ Qui-quadrado } & & $\mathrm{R}^{2}$ & $\%$ \\
\hline MROE-MIRCRE & 14,465 & 5,113 & 0,606 & 0,809 & 90,6 \\
\hline MROE-MIRTJ & 15,098 & 4,295 & 0,598 & 0,798 & 84,4 \\
\hline
\end{tabular}

FONTE: Próprio autor com base na saída do SPSS v.10.0

\subsubsection{Validação do modelo e significância dos indicadores contábeis e de riscos separadamente}

Da mesma forma ocorrida com os coeficientes de variação, os resultados dos testes com as médias dos indicadores contábeis e de riscos separadamente são satisfatórios para o modelo, mas não apresentam indicadores com significância estatística ao nível de 5\% e 10\%.

\subsubsection{Modelo com utilização de indicadores representativos das médias}

Ante o exposto, os indicadores MROE e MIRCRE, e MROE e MIRTJ, únicos com significância estatística, são utilizados na construção do modelo de classificação, representados pelas seguintes equações lineares: 
$Z_{i}=-2,147-0,032 * M R O E_{i}+0,042 * M R C R E_{i}$

$Z_{i}=-2,106-0,038 * M_{R O E}+0,001 * M_{i R T J}$

Onde:

MROE é a média dos indicadores de rentabilidade do patrimônio líquido;

MIRCRE é a média do índice de risco de crédito; e

MIRTJ é a média dos índices de risco da taxa de juros.

Considerando que a equação linear é parte da função logística, a probabilidade de ocorrência ou não de crise é calculada pela equação:

$$
\begin{aligned}
& P\left(\text { crise }_{i}\right)=\frac{1}{1+e^{-\left(-2,147-0,032^{*} M R O E_{i}+0,042^{*} M I R C R E_{i}\right)}} \\
& P\left(\text { crise }_{i}\right)=\frac{1}{1+e^{-\left(-2,106-0,038^{*} M R O E_{i}+0,001^{*} M I R T J_{i}\right)}}
\end{aligned}
$$

Os sinais dos coeficientes, por sua vez, estão de acordo com as expectativas em relação ao risco sistêmico. Enquanto o sinal do indicador da média da rentabilidade é corretamente negativo, os sinais das médias dos índices de risco de crédito e da taxa de juros são positivos.

Sobre a relevância dos coeficientes, na equação 40, há equivalência nos valores dos indicadores, mas ambos são inferiores à constante. Na equação 41, embora ambos sejam inferiores à constante, o indicador representativo da média da rentabilidade é 38 vezes mais relevante do que o indicador representativo do índice de taxa de juros.

\subsubsection{Desvios-padrão}

\subsubsection{Validação do modelo e significância dos indicadores}


Os resultados da regressão logística sobre os desvios-padrão dos indicadores contábeis e de riscos apresentam resultados semelhantes aos obtidos com os coeficientes de variação e as médias. Os testes de validação do modelo são satisfatórios, mas os indicadores não passam no teste de significância estatística ao nível de 5\% ou 10\% (Anexo F).

A Tabela 29 expõe o resumo dos testes de validação do modelo. Os testes Step, Block e Model mostram que os coeficientes da equação são diferentes de zero. Os testes de Hosmer e Lemeshow (H\&L) e -2LL são zero e informam não existir diferenças entre os valores preditos pelo modelo e os valores observados na realidade. Os coeficientes $\mathrm{R}^{2}$ de Cox \& Snell e Nagelkerke evidenciam a capacidade explicativa do modelo, confirmada no percentual de $100 \%$ de acerto.

Tabela 29 - Resumo dos testes de validação do modelo - indicadores representativos dos desvios-padrão

\begin{tabular}{|l|c|c|c|c|c|c|c|c|}
\hline Teste & Step & Block & Model & H\&L & -2LL & Cox\&Snell & Nagelkerke & Acerto \\
\hline Medida & \multicolumn{6}{|c|}{ Qui-quadrado } & \multicolumn{3}{|c|}{$\mathrm{R}^{2}$} & $\%$ \\
\hline Valores & 44,236 & 44,236 & 44,236 & 0,000 & 0,000 & 0,749 & 1,000 & 100,0 \\
\hline Significância & 0,000 & 0,000 & 0,000 & 1,000 & & & & \\
\hline
\end{tabular}

FONTE: Próprio autor com base na saída do SPSS v.10.0

Mais uma vez, como nos testes com os indicadores representativos dos coeficientes de variação e das médias, o teste de Wald exposto na Tabela 30 mostra que os indicadores não apresentam significância individualmente, quando inseridos conjuntamente no modelo.

Tabela 30 - Indicadores na equação - desvios-padrão

\begin{tabular}{|c|c|c|c|c|c|c|c|c|c|}
\hline & \multirow[b]{2}{*}{ B } & \multirow[b]{2}{*}{ S.E. } & \multirow[b]{2}{*}{ Wald } & \multirow[b]{2}{*}{ df } & \multirow[b]{2}{*}{ Sig. } & \multirow[b]{2}{*}{$\operatorname{Exp}(B)$} & \multicolumn{2}{|c|}{ 95,0\% C.I.for EXP(B) } \\
\hline & & & & & & & & Lower & Upper \\
\hline \multirow[t]{11}{*}{$\mathrm{a}$} & DATPL &, 000 & 21,587 & ,000 & 1 & 1,000 & 1,000 & ,000 & $2,4 \mathrm{E}+18$ \\
\hline & DALDT &,- 038 & 582,524 & ,000 & 1 & 1,000 & ,962 & ,000 & , \\
\hline & DCAOC &, 714 & 3919,867 & ,000 & 1 & 1,000 & 2,042 & ,000 & , \\
\hline & DNOPPL &,- 280 & 280,415 & ,000 & 1 & 1,000 & ,756 & ,000 & $3,70+238$ \\
\hline & DROE & ,321 & 356,442 & ,000 & 1 & 1,000 & 1,379 & ,000 & $3,50+303$ \\
\hline & DIRFX & ,015 & 15,861 & ,000 & 1 & 1,000 & 1,015 & ,000 & $3,2 E+13$ \\
\hline & DIRTJ & ,000 & 8,786 & ,000 & 1 & 1,000 & 1,000 & ,000 & $3,0 \mathrm{E}+07$ \\
\hline & DIRCRE & ,273 & 890,257 & ,000 & 1 & 1,000 & 1,314 & ,000 & , \\
\hline & DIRLIQ &,- 006 & 8,114 & ,000 & 1 & 1,000 & ,994 & ,000 & 8012904 \\
\hline & DIRATPIB &,- 055 & 181,420 & ,000 & 1 & 1,000 & ,946 & ,000 & $2,52+154$ \\
\hline & Constant & 2,86 & 34878,5 & ,000 & 1 & 1,000 & 17,492 & & \\
\hline
\end{tabular}

a. Variable(s) entered on step 1: DATPL, DALDT, DCAOC, DNOPPL, DROE, DIRFX, DIRTJ, DIRCRE, DIRLIQ, DIRATPIB. 
Pela análise da Tabela 31, os indicadores menos significativos e indicados para exclusão do modelo são os representativos dos desvios-padrão da alavancagem (DATPL), dos ativos líquidos sobre os depósitos totais (DALDT), do índice de risco de liquidez (DIRLIQ), e do índice de risco do ativo total sobre o PIB (DIRATPIB).

Tabela 31 - Significância dos indicadores fora da equação- desvios-padrão

\begin{tabular}{|lll|r|r|r|}
\hline & & \multicolumn{1}{|c|}{ Score } & df & \multicolumn{1}{c|}{ Sig. } \\
\hline Step & Variables & DATPL &, 189 & 1 &, 664 \\
& DALDT & 1,374 & 1 &, 241 \\
& DCAOC & 9,693 & 1 &, 002 \\
& DNOPPL & 5,211 & 1 &, 022 \\
& DROE & 7,453 & 1 &, 006 \\
& DIRFX & 7,225 & 1 &, 007 \\
& DIRTJ & 12,447 & 1 &, 000 \\
& DIRCRE & 6,360 & 1 &, 012 \\
& DIRLIQ &, 963 & 1 &, 326 \\
& DIRATPIB &, 010 & 1 &, 922 \\
& & 26,370 & 10 &, 003 \\
\hline
\end{tabular}

FONTE: Saída SPSS v.10.0

Entre os significativos ao nível de 5\%, são altamente correlacionados o desvio-padrão do índice de risco de câmbio (DIRFX) com os desvios-padrão dos créditos anormais e do índice de risco da taxa de juros (DCAOC e DIRTJ), o desvio-padrão do índice de risco de crédito (DIRCRE) com os desvios-padrão dos créditos anormais e do índice de risco da taxa de juros (DCAOC e o DIRTJ), e o desvio-padrão do índice de risco da taxa de juros (DIRTJ) com o desvio-padrão dos créditos anormais (DCAOC), não devendo ser submetidos à regressão conjuntamente.

Constatada a significância individual de cada indicador, adotou-se o mesmo procedimento aplicado às médias, com testes sobre os indicadores não-correlacionados, dois a dois.

Os resultados apresentados na Tabela 32 evidenciam que alguns pares de indicadores, apesar de propiciarem elevado percentual de acerto, não apresentam significância estatística ao nível de $10 \%$, inclusive na constante, não sendo possível utilizá-los para fins de classificação.

Os pares de indicadores significativos são representativos dos desvios-padrão da rentabilidade e do índice de risco de câmbio (DROE e DIRFX), da rentabilidade e do risco da taxa de juros 
(DROE e DIRTJ), da rentabilidade e do índice de risco de crédito (DROE e DIRCRE), e dos índices de risco de crédito e de câmbio (DIRCRE e DIRFX). A significância estatística os qualifica para compor a equação de classificação dos países em suscetíveis ou não-suscetíveis a crises.

Tabela 32 - Comparação dos resultados dos pares de indicadores significativos - desvios-padrão

\begin{tabular}{|l|c|c|c|c|c|c|c|c|c|c|c|c|}
\hline \multirow{2}{*}{$\begin{array}{l}\text { Indicador } \\
\text { testado }\end{array}$} & \multicolumn{2}{|c|}{ DROE-DCAOC } & \multicolumn{3}{c|}{ DROE-DIRFX } & \multicolumn{3}{c|}{ DROE-DIRTJ } & \multicolumn{3}{c|}{ DROE-DIRCRE } \\
\cline { 2 - 14 } & $\mathrm{B}$ & Wald & Sig. & B & Wald & Sig. & B & Wald & Sig. & B & Wald & Sig. \\
\hline DROE & 2,15 & 1,33 & 0,249 & 0,041 & 3,735 & 0,053 & 0,046 & 3,617 & 0,057 & 0,047 & 3,776 & 0,052 \\
\hline DCAOC & 0,07 & 0,407 & 0,524 & & & & & & & & & \\
\hline DIRFX & & & & 0,001 & 3,923 & 0,048 & & & & & & \\
\hline DIRTJ & & & & & & & 0,001 & 6,217 & 0,013 & & & \\
\hline DIRCRE & & & & & & & & & & 0,056 & 3,481 & 0,062 \\
\hline Constante & $-12,6$ & 1,03 & 0,310 & $-3,133$ & 7,652 & 0,006 & $-3,871$ & 9,043 & 0,003 & $-3,504$ & 7,076 & 0,008 \\
\hline
\end{tabular}

\begin{tabular}{|l|c|c|c|c|c|c|c|c|c|}
\hline \multirow{2}{*}{$\begin{array}{l}\text { Indicador } \\
\text { testado }\end{array}$} & \multicolumn{3}{|c|}{ DROE-DNOPPL } & \multicolumn{3}{c|}{ DIRCRE-DNOPPL } & \multicolumn{3}{c|}{ DIRCRE-DIRFX } \\
\cline { 2 - 10 } \\
\cline { 2 - 10 } DROE & B & Wald & Sig. & B & Wald & Sig. & B & Wald & Sig. \\
\hline DIRFX & & 6,529 & 0,011 & & & & & & \\
\hline DIRCRE & & & & & & & 0,001 & 4,107 & 0,043 \\
\hline DNOPPL & $-0,02$ & 5,700 & 0,017 & 0,009 & 2,659 & 0,103 & & & \\
\hline Constante & 0,918 & 0,874 & 0,350 & $-0,37$ & 0,104 & 0,747 & $-3,55$ & 7,595 & 0,006 \\
\hline
\end{tabular}

\begin{tabular}{|l|c|c|c|c|c|c|c|c|c|}
\hline \multirow{2}{*}{$\begin{array}{l}\text { Indicador } \\
\text { testado }\end{array}$} & \multicolumn{3}{|c|}{ DIRTJ-DNOPPL } & \multicolumn{3}{c|}{ DCAOC-DNOPPL } & \multicolumn{3}{c|}{ DIRFX-DNOPPL } \\
\cline { 2 - 10 } & $\mathrm{B}$ & Wald & Sig. & B & Wald & Sig. & B & Wald & Sig. \\
\hline DIRFX & & & & & & & 0,007 & 2,407 & 0,121 \\
\hline DCAOC & & & & 3,502 & 1,504 & 0,220 & & & \\
\hline DNOPPL & $-0,043$ & 4,828 & 0,028 & $-0,015$ & 0,902 & 0,342 & $-0,067$ & 3,697 & 0,055 \\
\hline DIRTJ & 0,003 & 5,647 & 0,017 & & & & & & \\
\hline Constante & 0,547 & 0,138 & 0,710 & $-11,37$ & 1,517 & 0,218 & 0,839 & 0,256 & 0,613 \\
\hline
\end{tabular}

FONTE: Próprio autor com base na saída do SPSS v.10.0

Quanto à identificação do modelo mais robusto, a Tabela 33 permite constatar que o par composto pelos indicadores DROE e DIRTJ exibe a menor diferença entre os valores preditos e os valores reais, tanto no valor de -2LL como no teste de H\&L.

Tabela 33 - Resumo dos testes de validação dos modelos - desvios-padrão

\begin{tabular}{|l|c|c|c|c|c|}
\hline Teste & -2LL & H\&L & Cox\&Snell & Nagelkerke & Acerto \\
\hline Medida & \multicolumn{2}{|c|}{ Qui-quadrado } & \multicolumn{2}{c|}{$\mathrm{R}^{2}$} & $\%$ \\
\hline DROE-DIRFX & 25,377 & 6,011 & 0,445 & 0,595 & 81,3 \\
\hline DROE-DIRTJ & 17,374 & 4,345 & 0,568 & 0,758 & 90,6 \\
\hline DROE-DIRCRE & 22,136 & 6,222 & 0,499 & 0,666 & 78,1 \\
\hline DIRCRE-DIRFX & 25,254 & 15,354 & 0,447 & 0,597 & 81,3 \\
\hline
\end{tabular}

FONTE: Próprio autor com base na saída do SPSS v.10.0 
Adicionalmente, apresenta os maiores valores para os coeficientes $\mathrm{R}^{2}$ de Cox \& Snell e Nagelkerke, indicando maior poder de explicação para a variância da variável dependente. Enfim, os indícios são ratificados pelo maior percentual de acerto $(90,6 \%)$. Os detalhes dos resultados da regressão estão no Anexo J.

\subsubsection{Validação do modelo e significância dos indicadores contábeis e de riscos separadamente}

Os resultados dos testes com os desvios-padrão dos indicadores contábeis e de riscos separadamente são similares aos obtidos com os coeficientes de variação e médias. Os testes de validação do modelo são satisfatórios e os indicadores não são significativos estatisticamente ao nível de $5 \%$ ou $10 \%$.

\subsubsection{Modelo com utilização de indicadores representativos dos desvios-padrão}

Identificados os indicadores e verificado o melhor modelo, a classificação dos países deve ser composta pelos indicadores DROE e DIRTJ, conforme a seguinte equação linear:

$Z_{i}=-3,871+0,046 * D_{R O E_{i}}+0,001 * \operatorname{DIRTJ}_{i}$

onde:

DROE é o desvio-padrão dos indicadores de rentabilidade do patrimônio líquido; e DIRTJ é o desvio-padrão dos índices de risco da taxa de juros.

A probabilidade de ocorrência ou não de crise é calculada pela equação da função logística:

$$
P\left(\text { crise }_{i}\right)=\frac{1}{1+e^{-\left(-3,871+0,046^{*} D R O E_{i}+0,001^{*} D I R T J_{i}\right)}}
$$

Os sinais positivos dos coeficientes dos indicadores representativos dos desvios-padrão são coerentes com o nível de risco sistêmico, pois quanto maior o desvio, maior o risco. 
Novamente, o indicador formado pela variável resultados apresenta magnitude bastante superior ao indicador formado pela taxa de juros, na ordem de 46 vezes.

\subsubsection{Análise individual dos indicadores}

No transcorrer das análises dos indicadores representativos dos coeficientes de variação, das médias e dos desvios-padrão, alguns indicadores salientaram-se isoladamente, em face da elevada significância estatística.

Entretanto, ao serem testados junto com outros, os problemas de correlação prejudicaram a validação do modelo e principalmente o resultado do teste de Wald. Na busca de soluções, os testes foram aplicados em cada um dos indicadores individualmente.

Tabela 34 - Resultados dos indicadores testados individualmente

\begin{tabular}{|l|c|c|c|c|c|c|c|}
\hline Indicador & $-2 \mathrm{LL}$ & H\&L & Nagelkerke & B & Wald & Sig. & Acerto\% \\
\hline CROE & 23,756 & 5,765 & 0,631 & 0,003 & 4,643 & 0,031 & 78,1 \\
Constante & & & & $-1,973$ & 7,377 & 0,007 & \\
\hline MATPL & 37,839 & 9,699 & 0,242 & 0,000 & 5,096 & 0,024 & 62,5 \\
Constante & & & & 2,449 & 4,249 & 0,039 & \\
\hline MROE & 35,593 & 10,998 & 0,316 & $-0,017$ & 5,919 & 0,015 & 84,4 \\
Constante & & & & 0,926 & 2,626 & 0,105 & \\
\hline MIRTJ & 28,163 & 6,609 & 0,527 & 0,000 & 8,008 & 0,005 & 78,1 \\
Constante & & & & $-2,681$ & 8,054 & 0,005 & \\
\hline MIRCRE & 24,554 & 5,550 & 0,613 & 0,029 & 7,117 & 0,008 & 81,3 \\
Constante & & & & $-3,206$ & 7,985 & 0,005 & \\
\hline DCAOC & 6,374 & 0,397 & 0,926 & 1,892 & 4,290 & 0,038 & 93,8 \\
Constante & & & & $-8,279$ & 4,114 & 0,043 & \\
\hline DNOPPL & 38,497 & 5,902 & 0,219 & $-0,009$ & 4,408 & 0,036 & 68,8 \\
Constante & & & & 1,277 & 2,990 & 0,084 & \\
\hline DROE & 33,107 & 5,520 & 0,392 & 0,051 & 4,021 & 0,045 & 75,0 \\
Constante & & & & $-1,460$ & 5,063 & 0,024 & \\
\hline DIRFX & 34,117 & 8,875 & 0,362 & 0,001 & 4,461 & 0,035 & 68,8 \\
Constante & & & & $-1,772$ & 4,998 & 0,025 & \\
\hline DIRTJ & 27,498 & 8,905 & 0,544 & 0,001 & 6,911 & 0,009 & 75,0 \\
Constante & & & & $-2,084$ & 7,884 & 0,004 & \\
\hline DIRCRE & 32,091 & 9,006 & 0,422 & 0,053 & 4,514 & 0,034 & 81,3 \\
Constante & & & & $-1,966$ & 5,384 & 0,020 & \\
\hline
\end{tabular}

FONTE: Próprio autor com base na saída do SPSS v.10.0

A Tabela 34 demonstra que os resultados dos testes com indicadores individuais são excelentes, sendo os melhores pela ordem de relevância o desvio-padrão dos créditos anormais (DCAOC), a média da rentabilidade (MROE), a média do índice de risco de crédito (MIRCRE), o desvio-padrão do índice de risco de crédito (DIRCRE), o coeficiente de variação da rentabilidade (CROE), a média do índice de risco da taxa de juros (MIRTJ), o 
desvio-padrão da rentabilidade (DROE) e o desvio-padrão do índice de risco da taxa de juros (DIRTJ), todos com percentual de acerto na classificação superior a 75\%.

Contudo, no intuito de utilizar os melhores modelos na classificação dos países, apenas os indicadores DCAOC e MROE (Anexos K e L), com acerto superior a 84,4\%, são indicados para compor as equações lineares:

$Z_{i}=-8,279+1,892 * D^{2} A O C_{i}$

$Z_{i}=+0,926-0,017 * M R O E_{i}$

Para o cálculo da probabilidade de ocorrência ou não de crise, as equações lineares devem integrar as respectivas equações da função logística:

$$
\begin{aligned}
& P\left(\text { crise }_{i}\right)=\frac{1}{1+e^{-\left(-8,279+1,892^{*} \text { DCAOC }_{i}\right)}} \\
& P\left(\text { crise }_{i}\right)=\frac{1}{1+e^{-\left(+0,926-0,017^{*} M R O E_{i}\right)}}
\end{aligned}
$$

Os sinais negativo e positivo da média da rentabilidade e do desvio-padrão dos créditos anormais, respectivamente, confirmam a relação esperada com o risco sistêmico.

Quanto aos coeficientes, observa-se, em ambas equações, a redução na diferença de magnitude entre a constante e o coeficiente, encontrada nas equações anteriores compostas pelas médias e coeficientes de variação. Isso implica em maior relevância dos indicadores no cálculo do valor de classificação.

\subsubsection{Interpretação dos resultados da análise de regressão logística}

Os resultados da análise de regressão logística demonstram que os indicadores relacionados ao crédito (MIRCRE e DCAOC), à rentabilidade (CROE, MROE e DROE) e à taxa de juros (CIRTJ, MIRTJ, e DIRTJ) são os que apresentam melhor significância estatística para 
classificar, com o maior percentual de acerto, os países como suscetíveis ou não a crises bancárias sistêmicas.

Embora todos apresentem significância estatística e elevada capacidade de classificar corretamente os grupos, os representativos dos desvios-padrão mostram, no conjunto, maior eficácia.

O percentual de acerto na classificação utilizando indicadores representativos dos desviospadrão (DCAOC, isoladamente, e DROE e DIRTJ, juntos) é superior a 90\%, enquanto com os indicadores representativos dos coeficientes e das médias varia de 84,4\% (CROE, CIRTJ, e MROE e MIRTJ, juntos) a 90\% (MROE e MIRCRE, juntos).

Individualmente, os coeficientes dos indicadores representativos dos desvios-padrão dos créditos anormais e da rentabilidade, e das médias da rentabilidade e do risco de crédito são os mais relevantes no cálculo dos valores utilizados na classificação dos países.

Por outro lado, os coeficientes dos indicadores da taxa de juros são muito baixos, quase nulos, não sendo expressivos no cálculo.

A evidência da volatilidade, como informação importante na identificação de situações de crise, deve ser considerada na análise dos indicadores utilizados na avaliação do risco sistêmico de cada período.

Costumeiramente, as análises são restritas aos indicadores calculados em datas-base específicas, sem a preocupação com as alternâncias precedentes. De forma contrária, o resultado do estudo ressalta o valor da informação contida na variância do comportamento do indicador nos períodos anteriores.

A constatação de diferentes níveis de periculosidade atribuídos a cada indicador nos diversos países, reforça a inserção do uso da volatilidade para quantificar e definir os padrões de cada um. Enquanto a alteração de um ponto percentual na taxa de juros em países industrializados é motivo de preocupação e, talvez, de adoção de medidas corretivas, o mesmo fato em países emergentes pode ser visto como corriqueiro e sem conseqüências. 
Assim, a principal vantagem analítica no uso da volatilidade está justamente em relevar as especificidades intrínsecas de cada sistema bancário e proporcionar padrões compatíveis com a realidade econômica no qual está inserido. A adoção de valores absolutos como padrões de comparação pode levar a conclusões indevidas no processo de avaliação da situação econômico-financeira dos diversos países.

Quanto aos aspectos contábeis identificados como relevantes, destaca-se o desvio-padrão dos créditos anormais em relação às operações de crédito, que, isoladamente, é capaz de classificar corretamente $93,8 \%$ dos países da amostra.

Notoriamente, esse indicador não apresenta resultados significativos quando testado junto com outros indicadores, em virtude da elevada correlação existente. A significativa dispersão apontada pela estatística descritiva é justificada pela diferenciação do valor do indicador em cada um dos dois grupos de países. Ou seja, os valores díspares estão concentrados em cada um dos grupos, diferenciando-os eficazmente.

Em termos qualitativos, o recrudescimento dos créditos anormais em momentos que antecedem as crises é uma característica diferenciadora esperada. $\mathrm{O}$ aumento nas taxas de juros, com vistas a proteger o valor da moeda do país, tem o efeito colateral de tornar o custo do crédito maior e dificultar o recebimento dos valores concedidos. Adicionalmente, a incerteza generalizada sobre a atividade econômica leva à contenção dos gastos e à diminuição da produção e da renda, limitando a capacidade de pagamento dos agentes.

Além do crédito, os indicadores representativos dos coeficientes de variação, das médias e dos desvios-padrão da rentabilidade e da taxa de juros aparecem como os mais eficazes na discriminação, quando utilizados conjuntamente, sendo que os desvios-padrão proporcionam o segundo melhor percentual de acerto na classificação $(90,6 \%)$.

A identificação do resultado como variável relevante é igualmente esperada, visto que representa a medida do desempenho e contém as conseqüências das decisões operacionais postas em prática pelas instituições. 
Diversos itens não significativos estatisticamente neste estudo, como os volumes e os riscos de liquidez e de câmbio, ou não incluídos nos testes pela limitação das informações contábeis, estão contidos no resultado.

A capacidade de discriminação do indicador de rentabilidade, tanto da média como do desviopadrão, ressalta a sensibilidade da variável resultado para diferenciar as situações que antecedem as crises e classificar os países.

A taxa de juros, por sua vez, caracteriza-se como o principal instrumento utilizado para proteger a moeda do país nos momentos que antecedem as crises. A finalidade é evitar a desvalorização da moeda mediante a elevação da taxa de juros.

$\mathrm{Na}$ amostra, esse fato ganha importância em face do regime de câmbio fixo observado na maior parte dos países nos períodos que antecedem as crises. Nesse cenário, a proteção da moeda nacional e, por conseguinte, do regime de câmbio fixo, somente pode ser feita pelo aumento da taxa de juros e/ou pela utilização das reservas internacionais.

Por esse motivo, a taxa de juros apresenta bruscas alterações nos momentos que antecedem a mudança do regime cambial, consistindo em relevante variável a ser monitorada na identificação de situações de estresse.

A elevada correlação negativa entre a taxa de juros e a taxa de câmbio é motivada pelo incremento das posições líquidas passivas concomitantemente ao aumento das taxas de juros. Mesmo em situações normais, a elevação das taxas de juros em determinado país atrai os investimentos internacionais, aumentando o volume de passivos em moeda estrangeira.

Nesse contexto, uma ou outra taxa apareceria como discriminante da situação prévia à crise. Contudo, haja vista que alguns países sem crise da amostra apresentam elevada posição líquida passiva em moeda estrangeira, como a Nova Zelândia e a Noruega, os indicadores elaborados com base na taxa de juros mostraram-se mais eficazes na diferenciação.

Finalmente, o último conjunto de indicadores relevantes na classificação é formado pelas médias do índice de risco de crédito e da rentabilidade (MIRCRE e MROE), com percentual de acerto igual a 90,6\%. Como a média e o desvio-padrão do índice de risco de crédito tem 
correlação com os respectivos valores contábeis dos créditos anormais e, dada a capacidade de classificação do indicador DCAOC isoladamente, torna-se natural que os demais indicadores, formulados com base no crédito e menos correlacionados, sejam significativos junto com outros indicadores. 


\section{AVALIAÇÃO E APLICAÇÃO DAS EQUAÇÕES}

\subsection{Avaliação das equações}

As equações resultantes dos modelos validados e compostas pelos indicadores com significância estatística foram testadas para verificar qual delas maximiza o percentual de acerto considerado prioritário.

Conforme definido na metodologia, o objetivo é identificar qual equação reduz a quantidade de erro tipo I. No caso, considerou-se o erro tipo I aquele em que um país suscetível à crise tenha sido classificado no grupo não suscetível. Em conseqüência, o erro tipo II ocorreu quando um país não-suscetível foi classificado no grupo suscetível à crise.

A busca pela redução do erro tipo I é justificada pelas piores conseqüências advindas em classificar um país suscetível à crise como não-suscetível. O custo do desconhecimento da situação é bem superior ao custo de indicar um país não-suscetível como suscetível.

Assim, procedeu-se a escolha da melhor equação de classificação com a utilização da fórmula 34, detalhada na metodologia.

As equações submetidas ao teste para verificar qual maximiza o percentual de acerto considerado prioritário são as seguintes:

Equação 1: $P\left(\right.$ crise $\left._{i}\right)=\frac{1}{1+e^{-\left(-3,812+0,003^{*} C R O E_{i}+0,004^{*} \operatorname{CIRTJ}_{i}\right)}}$

Equação 2: $P\left(\right.$ crise $\left._{i}\right)=\frac{1}{1+e^{-\left(-2,147-0,032^{*} M R O E_{i}+0,042^{*} M I R C R E_{i}\right)}}$

Equação 3: $P\left(\right.$ crise $\left._{i}\right)=\frac{1}{1+e^{-\left(-2,106-0,038^{*} M R O E_{i}+0,001^{*} M I R T J_{i}\right)}}$ 
Equação 4: $P\left(\right.$ crise $\left._{i}\right)=\frac{1}{1+e^{-\left(-3,871+0,046^{*} D R O E_{i}+0,001^{*} D I R T J_{i}\right)}}$

Equação 5: $P\left(\right.$ crise $\left._{i}\right)=\frac{1}{1+e^{-\left(-8,279+1,892^{*} D C A O C_{i}\right)}}$

Equação 6: $P\left(\right.$ crise $\left._{i}\right)=\frac{1}{1+e^{-\left(+0,926-0,017^{*} M R O E_{i}\right)}}$

Conforme a Tabela 35, os resultados do IAM (índice de avaliação do modelo) demonstram que a melhor equação para classificar os países como suscetíveis ou não a crises bancárias sistêmicas é a de número 5, com o menor valor de IAM $(0,071)$. Em seguida, aparecem as equações de números 2 e 4, com os segundos melhores IAM.

Tabela 35 - Teste de maximização das equações

\begin{tabular}{|c|c|c|c|c|c|}
\hline \multirow[t]{2}{*}{ Equação } & \multirow[t]{2}{*}{ Observados } & \multicolumn{2}{|c|}{ Preditos } & \multirow{2}{*}{$\begin{array}{l}\text { Percentual de } \\
\text { acerto }\end{array}$} & \multirow[t]{2}{*}{ IAM } \\
\hline & & sem crise & com crise & & \\
\hline \multirow{2}{*}{$\begin{array}{l}\text { Equação1 } \\
\text { CROE e CIRTJ }\end{array}$} & 17 sem crise & 15 & 2 & 88,2 & \multirow[t]{2}{*}{0,171} \\
\hline & 15 com crise & 3 & 12 & 80 & \\
\hline \multirow{2}{*}{$\begin{array}{l}\text { Equação2 } \\
\text { MROE e MIRCRE }\end{array}$} & 17 sem crise & 16 & 1 & 94,1 & \multirow[t]{2}{*}{0,080} \\
\hline & 15 com crise & 2 & 13 & 86,7 & \\
\hline \multirow{2}{*}{$\begin{array}{l}\text { Equação3 } \\
\text { MROE e MIRTJ }\end{array}$} & 17 sem crise & 15 & 2 & 88,2 & \multirow[t]{2}{*}{0,171} \\
\hline & 15 com crise & 3 & 12 & 80 & \\
\hline \multirow{2}{*}{$\begin{array}{l}\text { Equação } 4 \\
\text { DROE e DIRTJ }\end{array}$} & 17 sem crise & 16 & 1 & 94,1 & \multirow[t]{2}{*}{0,080} \\
\hline & 15 com crise & 2 & 13 & 86,7 & \\
\hline \multirow{2}{*}{$\begin{array}{l}\text { Equação } 5 \\
\text { DCAOC }\end{array}$} & 17 sem crise & 16 & 1 & 94,1 & \multirow[t]{2}{*}{0,071} \\
\hline & 15 com crise & 1 & 14 & 93,3 & \\
\hline \multirow{2}{*}{$\begin{array}{l}\text { Equação } 6 \\
\text { MROE }\end{array}$} & 17 sem crise & 15 & 2 & 88,2 & \multirow[t]{2}{*}{0,171} \\
\hline & 15 com crise & 3 & 12 & 80 & \\
\hline
\end{tabular}

FONTE: Próprio autor com base na saída do SPSS v.10.0

Coincidentemente, as equações que maximizam a classificação são as mesmas que apresentam o maior percentual de acerto geral.

Ante o exposto, resta a aplicação das regras de classificação, tanto sobre os períodos e os países da amostra como sobre outras situações não inclusas, para fins de generalização dos modelos. 


\subsection{Aplicação das equações}

\subsubsection{Países e períodos da amostra}

A classificação dos países da amostra como suscetíveis ou não a crises bancárias é realizada com base nas equações 2, 4 e 5, identificadas como as melhores pelo IAM, na medida em que maximizam o percentual de acerto observando a prioridade estabelecida de privilegiar a menor quantidade de erros tipo I.

O cálculo é feito pela substituição dos valores dos indicadores nas equações, sendo que os valores resultantes são relativos e não comparáveis numericamente entre as equações. Servem para classificar e ordenar o nível de propensão ao risco de cada país, exclusivamente pela equação empregada.

Como a métrica utilizada é derivada dos valores da constante e dos coeficientes $(\beta)$ de cada indicador, discrepâncias na magnitude desses valores produzem intervalos significativos entre a terceira e a quinta casa decimal. Na busca de apresentar valores mais compreensíveis na classificação, em percentuais, os indicadores MROE, MIRCRE, DROE, DIRTJ e DCAOC foram multiplicados por mil (1000).

O ponto de corte utilizado pela técnica na classificação é o valor $0,5(50 \%)$, obtido quando o resultado da equação linear é igual a zero. Na situação em que o resultado da equação linear é maior do que zero $(Z(i)>0)$, a equação logística retorna um valor maior do que 0,5 $(\mathrm{P}(1)>$ $0,5)$. Caso contrário, o resultado da equação linear é menor do que zero $(Z(i)<0)$ e a equação logística apresenta um valor menor do que $0,5(\mathrm{P}(1)<0,5)^{62}$.

A comparação entre os resultados das equações e o valor do ponto de corte classifica os países com resultados superiores como pertencentes ao grupo suscetível à crise (grupo 1), e aqueles com resultados inferiores no grupo não-suscetível (grupo 0).

O valor resultante da equação, em percentual, é diretamente interpretado como a probabilidade de ocorrência de crise.

62. A interpretação gráfica dos resultados das equações lineares e respectivas probabilidades pode ser efetuada na Figura 4 - Curva da regressão logística. 


\subsubsection{Exemplo de aplicação das equações}

Com vistas a detalhar o processo de cálculo da probabilidade que determina a classificação dos países nos grupos suscetível e não-suscetível à crise, elaborou-se um exemplo com a equação de melhor resultado no IAM:

Equação 5: $P\left(\right.$ crise $\left._{i}\right)=\frac{1}{1+e^{-\left(-8,279+1,892^{*} D C A O C_{i}\right)}}$

Para facilitar o acompanhamento, a Tabela 36 exibe os valores resultantes em cada etapa nas colunas 3, 4 e 5. A primeira etapa consiste em solucionar a equação linear “-8,279+1,892 *DCAOC", denominada “Z(i)".

Como mencionado, os indicadores DCAOC de cada país, expostos na coluna 2, estão multiplicados por mil (1000) para torná-los mais representativos e compreensíveis no processo de classificação.

A coluna 3 traz os resultados obtidos pela aplicação da equação linear Z(i). Nessa etapa, são conhecidas as classificações dos países em um dos dois grupos, pois os valores positivos $(Z(i)>0)$ correspondem aos países suscetíveis e os valores negativos $(Z(i)<0)$ aos países nãosuscetíveis.

A próxima etapa é utilizar esses valores como expoentes da constante matemática $e\left(\mathrm{e}^{-\mathrm{Z}(\mathrm{i})}\right)$. Os resultados, mostrados na coluna 4, são próximos a zero para os países de maior risco (suscetíveis à crise) e significativamente superiores a zero para os países de menor risco (nãosuscetíveis à crise). Quanto menor o valor, maior é a probabilidade de crise, e vice-versa.

A última etapa é calcular o inverso da coluna 4, adicionado de um, conforme a equação logística:

$P\left(\right.$ crise $\left._{i}\right)=\frac{1}{1+e^{-(Z(i))}}$

O resultado, exposto em percentual na coluna 5, é a probabilidade de crise calculada para cada país. 
Tabela 36 - Exemplo de aplicação da equação 5

\begin{tabular}{|c|c|c|c|c|}
\hline $\begin{array}{l}\text { coluna } 1 \\
\text { PAIISES }\end{array}$ & $\begin{array}{c}\text { coluna } 2 \\
\text { DCAOC * }\end{array}$ & $\begin{array}{c}\text { coluna } 3-\mathrm{Z}(\mathrm{i})= \\
-8,279+1,892 * \text { DCAOC }\end{array}$ & $\begin{array}{c}\text { coluna } 4 \\
\operatorname{EXP}(-Z(i))\end{array}$ & $\begin{array}{c}\text { coluna } 5 \\
1 /(1+\operatorname{EXP}(-Z(i))\end{array}$ \\
\hline ARG1 & 8,308 & 7,4404 & 0,000587 & $99,94 \%$ \\
\hline ARG2 & 11,993 & 14,4110 & 0,000001 & $100,00 \%$ \\
\hline EQU & 8,132 & 7,1061 & 0,000820 & $99,92 \%$ \\
\hline INDO & 51,319 & 88,8159 & 0,000000 & $100,00 \%$ \\
\hline TAI & 3,840 & $-1,0138$ & 2,755918 & $26,62 \%$ \\
\hline KOR & 6,880 & 4,7375 & 0,008760 & $99,13 \%$ \\
\hline MEX & 6,417 & 3,8629 & 0,021008 & $97,94 \%$ \\
\hline URU & 5,048 & 1,2710 & 0,280544 & $78,09 \%$ \\
\hline RUS & 30,364 & 49,1698 & 0,000000 & $100,00 \%$ \\
\hline TUR & 6,175 & 3,4036 & 0,033253 & $96,78 \%$ \\
\hline CROA & 25,793 & 40,5213 & 0,000000 & $100,00 \%$ \\
\hline FIN & 8,284 & 7,3934 & 0,000615 & $99,94 \%$ \\
\hline BRA95 & 10,266 & 11,1447 & 0,000014 & $100,00 \%$ \\
\hline BRA99 & 70,944 & 125,9464 & 0,000000 & $100,00 \%$ \\
\hline AULIA & 1,344 & $-5,7363$ & 309,9176 & $0,32 \%$ \\
\hline AUST & 0,867 & $-6,6393$ & 764,5825 & $0,13 \%$ \\
\hline CAN & 1,614 & $-5,2250$ & 185,8641 & $0,54 \%$ \\
\hline FRA & 2,894 & $-2,8030$ & 16,4933 & $5,72 \%$ \\
\hline GERM & 1,406 & $-5,6185$ & 275,4723 & $0,36 \%$ \\
\hline ITA & 0,889 & $-6,5979$ & 733,5560 & $0,14 \%$ \\
\hline HOLA & 0,122 & $-8,0476$ & 3126,4173 & $0,03 \%$ \\
\hline NZEL & 0,823 & $-6,7223$ & 830,7069 & $0,12 \%$ \\
\hline PORT & 2,357 & $-3,8202$ & 45,6134 & $2,15 \%$ \\
\hline ESPA & 3,240 & $-2,1498$ & 8,5831 & $10,43 \%$ \\
\hline \begin{tabular}{|l|} 
SUE97 \\
\end{tabular} & 0,967 & $-6,4498$ & 632,5994 & $0,16 \%$ \\
\hline UK & 1,300 & $-5,8201$ & 337,0119 & $0,30 \%$ \\
\hline USA & 0,638 & $-7,0726$ & 1179,2064 & $0,08 \%$ \\
\hline FIN97 & 3,111 & $-2,3939$ & 10,9559 & $8,36 \%$ \\
\hline DIN95 & 0,725 & $-6,9067$ & 998,9511 & $0,10 \%$ \\
\hline ISLAN & 5,330 & 1,8061 & 0,1643 & $85,89 \%$ \\
\hline NOR95 & 1,268 & $-5,8805$ & 358,0021 & $0,28 \%$ \\
\hline VEN88 & 40,408 & 68,1722 & 0,000000 & $100,00 \%$ \\
\hline
\end{tabular}

FONTE: Próprio autor com base na saída do SPSS v.10.0

* Os valores estão multiplicados por mil (1000).

Em termos de interpretação da equação, o coeficiente do indicador DCAOC informa a variação produzida no logaritmo natural da razão de chances quando o mesmo variar uma unidade. No caso, a variação de uma unidade em DCAOC provoca a variação de 1,892 vez no logaritmo natural da razão de chances, exatamente como acontece em um modelo linear.

Contudo, essa informação não exprime a variação na probabilidade de ocorrer o evento (em percentual). Para conhecer, há necessidade de calcular o antilogaritmo do coeficiente, cujo 
valor neste caso é 6,6326 ( $\left.\mathrm{e}^{1,892}\right)$. Assim, é possível afirmar que a variação de uma unidade no indicador DCAOC, para o logaritmo natural da razão de chances em que o coeficiente foi inicialmente estimado, resulta no aumento ou na diminuição, dependendo do sinal da variação, de 563,26\% na probabilidade de ocorrência do evento (GUJARATI, 2000, p. 565).

Entretanto, por vezes, a questão emergente é determinar qual é a variação a partir de uma probabilidade já estimada. Para encontrar a resposta, faz-se importante ressaltar que a variação é condicionada tanto pelo valor do indicador quanto pelo valor do coeficiente ${ }^{63}$.

A título de exemplo, supondo-se que o valor do indicador DCAOC da Tailândia (TAI), de 3,840 , com indicação de $26,62 \%$ para ocorrência de crise, seja acrescido de uma unidade, para 4,840. Nesse valor, a probabilidade de crise aumenta para $70,65 \%$, equivalente a uma variação de 165,34\%. Utilizando-se o mesmo critério de cálculo para o México (MEX), ao somar uma unidade ao valor de 6,417 , obtém-se 7,417, e a probabilidade de crise aumenta de 97,94\% para 99,68\%, correspondente à variação de 1,78\%.

A significativa discrepância entre os percentuais de variação é motivada pela diferença entre os valores do indicador DCAOC da Tailândia e do México.

O apêndice 4 apresenta o percentual de variação que ocorreria em cada país da amostra, caso houvesse o acréscimo de uma unidade no indicador DCAOC.

\subsubsection{Classificação geral}

Explicitado o cálculo dos percentuais de classificação com a utilização as equações, bem como as interpretações possíveis aos coeficientes dos indicadores, a Tabela 37 apresenta a classificação geral dos países em ordem decrescente de risco (maior risco acima), de acordo com o percentual de probabilidade obtido pelas três equações.

63. De acordo com Gujarati $\left(2000\right.$, p.560) “[...] pode-se mostrar que $\mathrm{dP} / \mathrm{dX}=\beta_{2} \mathrm{P}(1-\mathrm{P})$, que mostra a taxa de variação na probabilidade relativa a X envolve não somente $\beta_{2}$, mas também o nível de probabilidade a partir do qual é medida a variação. A propósito, note que o efeito da variaçao de uma unidade em $\mathrm{X}$ sobre $\mathrm{P}$ é máximo quando $\mathrm{P}=0,5$, e, mínimo, quando $\mathrm{P}$ é próximo de zero (0) ou um (1)”. 
Tabela 37 - Classificação dos países

\begin{tabular}{|c|c|c|c|c|c|c|c|c|c|c|c|}
\hline \multirow[b]{2}{*}{ PAÍS } & \multirow{2}{*}{\begin{tabular}{|c|} 
Equação 2 \\
MROE-MIRCRE
\end{tabular}} & \multicolumn{2}{|c|}{ Classificação } & \multirow[b]{2}{*}{ PAÍS } & \multicolumn{3}{|c|}{ Equação 4 Classificação } & \multirow[b]{2}{*}{ PAÍS } & \multirow{2}{*}{$\begin{array}{c}\text { Equação } 5 \\
\text { DCAOC }\end{array}$} & \multicolumn{2}{|c|}{ Classificação } \\
\hline & & Início & Fim & & DROE-DIRTJ & Início & Fim & & & Início & Fim \\
\hline BRA99 & $100,0 \%$ & 1 & 1 & VEN88 & $100,0 \%$ & 1 & 1 & INDO & $100,0 \%$ & 1 & 1 \\
\hline INDO & $100,0 \%$ & 1 & 1 & TUR & $100,0 \%$ & 1 & 1 & RUS & $100,0 \%$ & 1 & 1 \\
\hline BRA95 & $100,0 \%$ & 1 & 1 & URU & $100,0 \%$ & 1 & 1 & CROA & $100,0 \%$ & 1 & 1 \\
\hline FIN & $100,0 \%$ & 1 & 1 & INDO & $100,0 \%$ & 1 & 1 & BRA99 & $100,0 \%$ & 1 & 1 \\
\hline EQU & $100,0 \%$ & 1 & 1 & FIN & $100,0 \%$ & 1 & 1 & VEN88 & $100,0 \%$ & 1 & 1 \\
\hline VEN88 & $99,9 \%$ & 1 & 1 & EQU & $99,9 \%$ & 1 & 1 & ARG2 & $100,0 \%$ & 1 & 1 \\
\hline KOR & $99,8 \%$ & 1 & 1 & TAI & $99,8 \%$ & 1 & 1 & BRA95 & $100,0 \%$ & 1 & 1 \\
\hline URU & $99,1 \%$ & 1 & 1 & BRA95 & $99,6 \%$ & 1 & 1 & ARG1 & $99,9 \%$ & 1 & 1 \\
\hline CROA & $95,1 \%$ & 1 & 1 & RUS & $99,1 \%$ & 1 & 1 & FIN & $99,9 \%$ & 1 & 1 \\
\hline TUR & $94,1 \%$ & 1 & 1 & MEX & $97,9 \%$ & 1 & 1 & EQU & $99,9 \%$ & 1 & 1 \\
\hline ISLAN & $91,0 \%$ & 0 & 1 & KOR & $97,8 \%$ & 1 & 1 & KOR & $99,1 \%$ & 1 & 1 \\
\hline ARG2 & $86,4 \%$ & 1 & 1 & ARG2 & $96,9 \%$ & 1 & 1 & MEX & $97,9 \%$ & 1 & 1 \\
\hline ARG1 & $74,0 \%$ & 1 & 1 & ISLAN & $94,7 \%$ & 0 & 1 & TUR & $96,8 \%$ & 1 & 1 \\
\hline RUS & $66,4 \%$ & 1 & 1 & BRA99 & $79,5 \%$ & 1 & 1 & ISLAN & $85,9 \%$ & 0 & 1 \\
\hline MEX & $42,6 \%$ & 1 & 0 & ITA & $37,3 \%$ & 0 & 0 & URU & $78,1 \%$ & 1 & 1 \\
\hline FRA & $40,8 \%$ & 0 & 0 & FIN97 & $36,3 \%$ & 0 & 0 & TAI & $26,6 \%$ & 1 & 0 \\
\hline ESPA & $23,7 \%$ & 0 & 0 & NZEL & $35,1 \%$ & 0 & 0 & ESPA & $10,4 \%$ & 0 & 0 \\
\hline TAI & $22,7 \%$ & 1 & 0 & CROA & $34,0 \%$ & 1 & 0 & FIN97 & $8,4 \%$ & 0 & 0 \\
\hline ITA & $19,1 \%$ & 0 & 0 & UK & $29,0 \%$ & 0 & 0 & FRA & $5,7 \%$ & 0 & 0 \\
\hline PORT & $10,7 \%$ & 0 & 0 & NOR95 & $27,3 \%$ & 0 & 0 & PORT & $2,1 \%$ & 0 & 0 \\
\hline GERM & $9,0 \%$ & 0 & 0 & CAN & $18,5 \%$ & 0 & 0 & CAN & $0,5 \%$ & 0 & 0 \\
\hline AULIA & $6,8 \%$ & 0 & 0 & ARG1 & $11,9 \%$ & 1 & 0 & GERM & $0,4 \%$ & 0 & 0 \\
\hline CAN & $5,3 \%$ & 0 & 0 & FRA & $11,9 \%$ & 0 & 0 & AULIA & $0,3 \%$ & 0 & 0 \\
\hline SUE97 & $3,6 \%$ & 0 & 0 & SUE97 & $8,4 \%$ & 0 & 0 & NOR95 & $0,3 \%$ & 0 & 0 \\
\hline AUST & $3,3 \%$ & 0 & 0 & AUST & $8,4 \%$ & 0 & 0 & SUE97 & $0,2 \%$ & 0 & 0 \\
\hline UK & $1,9 \%$ & 0 & 0 & PORT & $6,8 \%$ & 0 & 0 & UK & $0,1 \%$ & 0 & 0 \\
\hline NZEL & $1,5 \%$ & 0 & 0 & USA & $5,3 \%$ & 0 & 0 & ITA & $0,1 \%$ & 0 & 0 \\
\hline FIN97 & $1,0 \%$ & 0 & 0 & DIN95 & $5,1 \%$ & 0 & 0 & AUST & $0,1 \%$ & 0 & 0 \\
\hline DIN95 & $0,7 \%$ & 0 & 0 & ESPA & $5,1 \%$ & 0 & 0 & NZEL & $0,1 \%$ & 0 & 0 \\
\hline USA & $0,6 \%$ & 0 & 0 & HOLA & $5,1 \%$ & 0 & 0 & DIN95 & $0,1 \%$ & 0 & 0 \\
\hline HOLA & $0,5 \%$ & 0 & 0 & AULIA & $5,0 \%$ & 0 & 0 & USA & $0,1 \%$ & 0 & 0 \\
\hline NOR95 & $0,5 \%$ & 0 & 0 & GERM & $3,6 \%$ & 0 & 0 & HOLA & $0,0 \%$ & 0 & 0 \\
\hline
\end{tabular}

FONTE: Próprio autor com base na saída do SPSS v.10.0

Pelo exposto, a diferença entre as probabilidades dos países suscetíveis e não-suscetíveis à crise é significativa, principalmente na classificação resultante da aplicação da equação 5 , que utiliza o indicador DCAOC, visto que as probabilidades dos últimos classificados como suscetíveis e não suscetíveis à crise é de $78,1 \%$ e $26,6 \%$, respectivamente, evidenciando uma diferença de 51,5 pontos percentuais entre os grupos. 
A diferença de probabilidade entre os últimos classificados pela equação 4, Itália e Brasil, com dados de 1999, é de 42,2 pontos percentuais. A equação 2, também significativa, apresenta a menor diferença entre os grupos, de 23,8 pontos percentuais.

A distribuição das probabilidades entre os países pertencentes ao grupo suscetível ou nãosuscetível revela a capacidade dos indicadores em discriminar as situações. Notoriamente, a maior parte dos países suscetíveis à crise apresenta probabilidades próximas ou igual a 100\%, enquanto a probabilidade dos países não-suscetíveis aproxima-se de zero.

Nesse sentido, salienta-se também a coerência entre as classificações. Com exceção de poucos países, as probabilidades indicadas pelas três equações para pertencer a um dos grupos encontram-se na mesma faixa, sem discrepâncias significativas.

A conclusão é que as três equações, utilizando os indicadores MROE, MIRCRE, DROE, DIRTJ e DCAOC, classificam mais de $90 \%$ dos países corretamente nos grupos suscetível e não-suscetível à crise.

O percentual de erro deve-se à classificação de alguns países pela técnica no grupo diferente do estabelecido inicialmente. Geralmente, a classificação errada do país acontece pela ausência de valores compatíveis nos indicadores usados à classificação, com aqueles esperados para o respectivo grupo.

Pode ser originada tanto pela classificação inicial errada, quando o país é incluído no outro grupo, como pela falta de informações contábeis. A recomendação para essas situações é proceder a uma análise pormenorizada das características do país classificado errado para encontrar os motivos causadores.

Os países classificados indevidamente são a Islândia, pelas três equações, a Tailândia, pelas equações 2 e 5, o México, pela equação 2, e a Croácia e a Argentina, com dados de 1995, pela equação 4.

A elevada probabilidade da Islândia em pertencer ao grupo dos países suscetíveis à crise não deixa dúvidas de que os indicadores apresentam valores próximos aos países pertencentes a esse grupo e que houve engano na classificação inicial. O estudo mais detalhado esclarece que 
a Islândia incorreu em problemas no sistema bancário contemporaneamente à Dinamarca, Finlândia, Noruega e Suécia, entre os anos de 1991 e 1994. Dessa forma, somente com indicadores calculados com dados a partir de $1995^{64}$, como foi feito para os demais países nórdicos, a probabilidade da Islândia em pertencer ao grupo sem crises seria superior a 50\%.

Por outro motivo, o México e a Tailândia foram igualmente classificados indevidamente no grupo dos países sem crise pelas equações que utilizam os indicadores MROE, MIRCRE e DCAOC.

Os dados do México mostram que o percentual de créditos anormais permaneceu constante, em torno de 9,5\%, no período entre dezembro de 1993 e dezembro de 1994. Assim, o índice de risco de crédito, com a média em 17\%, não é significativo em relação ao patrimônio líquido. Além disso, a elevada rentabilidade do período, atingindo 31,9\% em dezembro de 1993, impossibilitou a correta classificação do país no grupo suscetível à crise. Apesar disso, o México é o pior país classificado como não-suscetível e a probabilidade de crise é de $42,6 \%$, nada desprezível.

A análise da Tailândia, por sua vez, expõe que o baixo valor dos créditos anormais nos períodos que antecederam a crise, com média de $2,6 \%$ do total de créditos, foi a causa da alteração. Os dados das demonstrações contábeis de junho, setembro e dezembro de 1998, relativos ao período pós-crise, apresentam créditos anormais correspondentes a 9,0\%, 10,4\% e $13,7 \%$, respectivamente. A conclusão é que a baixa probabilidade de suscetibilidade à crise foi motivada pela falta de reconhecimento contábil dos créditos anormais em nível adequado no período pré-crise.

Outros dois países incluídos no grupo alterno à classificação inicial, pela equação formulada com os indicadores DROE e DIRTJ, foram a Croácia e a Argentina na crise de $1995^{65}$. A análise dos indicadores dos países mostra que a baixa volatilidade na taxa de juros e no resultado coaduna-se com o grupo sem crises.

Na Argentina, a alteração significativa na taxa de juros, de 5,7\% para 9,9\%, ocorreu em março de 1995, data da crise não computada no cálculo do indicador. Assim, o desvio-padrão 
dos quatro períodos anteriores à crise permaneceu praticamente estável. Em adição, os lucros e prejuízos nos quatro períodos que antecederam a crise são próximos a zero, resultando em um desvio-padrão insignificante.

A Croácia, apesar da taxa de juros elevada, com média igual a 9,1\%, não apresentou alterações significativas entre os meses de dezembro de 1997 e de 1998, com variação de $8,8 \%$ para $11 \%$. Em termos de resultado, repete-se o fato constatado na Argentina em março de 1995, ou seja, são inexpressivos e giram em torno de zero.

Mesmo assim, a Croácia apresenta 34\% de chances de suscetibilidade à crise. Essa razoável probabilidade conduziu a checagem dos dados. Os cálculos dos indicadores DROE e DIRTJ utilizando mais um trimestre anterior, referente a setembro de 1997, resultaria em uma probabilidade superior a $50 \%$ e classificaria a Croácia como suscetível à crise.

Em resumo, o indicador do desvio-padrão dos créditos anormais classificou corretamente todos os países, inclusive aqueles com classificação inicial errada, como a Islândia e a Tailândia, demonstrando muita precisão. Nessa linha, a média da rentabilidade do patrimônio líquido e a média do índice de risco de crédito também apresentaram elevado percentual de acerto na classificação, falhando apenas no México. Os indicadores dos desvios-padrão da rentabilidade e da taxa de juros, todavia, não conseguiram captar as diferenças dos grupos suscetíveis e não-suscetíveis para a Croácia e Argentina, em 1995.

\subsubsection{Períodos fora da amostra}

A aplicação das equações nos componentes da amostra ratifica a validação dos modelos e possibilitam a compreensão dos efeitos dos indicadores considerados relevantes. Entretanto, não responde a dúvida sobre a aplicabilidade em situações que não compuseram o processo de elaboração dos modelos.

A complementação da validação consiste em aplicar as equações em períodos e/ou países diferentes daqueles que contribuíram à formulação. Assim, a mensuração longitudinal do risco sistêmico foi realizada em países com dados disponíveis em outros períodos. 
Para mensurar o risco sistêmico existente no setor bancário de cada país ao longo do tempo, bem como propiciar melhor interpretação, construíram-se três índices de risco sistêmico (IRS), sendo denominados IRS2, IRS4 e IRS5, e correspondentes às equações 2, 4 e 5, respectivamente.

A construção dos IRS considerou o percentual de acerto ao acaso, de 53,125\%, que seria obtido na situação em que todas as observações fossem classificadas no grupo preponderante (não-suscetível à crise), para identificar o valor, entre os resultados de cada equação, correspondente ao ponto de corte entre os dois grupos.

Assim, o valor localizado no percentil 53,125 (17/32) dos resultados da aplicação das equações 2, 4 e 5 é assumido como o ponto limítrofe dos grupos não-suscetível e suscetível à crise, porque induz a separação de dezessete e quinze países $(53,125 \%$ e $46,825 \%$ das observações) em cada um dos grupos, conforme definido inicialmente.

Exemplificando, para a equação 2, que utiliza os indicadores MROE e MIRCRE, os valores resultantes estão contidos no intervalo [0,10431;0,10869]. O valor do ponto de corte, encontrado na posição do percentil 53,125 desses valores, é 0,10478. Sob o mesmo raciocínio, para a equação 4, com base nos indicadores DROE e DIRTJ, os valores estão no intervalo [0,02042; 0,02100] e o ponto de corte é 0,02048 . Para a equação 5 , formada unicamente pelo indicador DCAOC, os valores estão entre [0,000254;0,000290] e o ponto de corte é 0,000256 . Os cálculos dos pontos de corte das equações estão detalhados no apêndice 5.

Para obtenção dos IRS em diversos períodos, basta deduzir o valor do ponto de corte das equações 2, 4 e 5, definidos como 0,10478; 0,02048; e 0,000256, respectivamente, do resultado calculado em cada período pela aplicação da equação correspondente.

A opção de utilizar os IRS, no lugar do valor das probabilidades resultantes da equação logística, é justificada pela maior sensibilidade dos IRS em demonstrar as alterações no risco ao longo do tempo. Apesar de apontarem as mesmas situações, a métrica usada na classificação pela regressão logística não possibilita identificar algumas diferenças.

Por exemplo, na classificação geral dos países pela equação 4, exposta na Tabela 35, um grupo de países apresenta $100 \%$ de probabilidade de pertencer ao grupo suscetível. Pelo 
cálculo dos respectivos IRS de cada país, todos são elevados, mas apresentam diferenças. O IRS da Venezuela (VEN88) é 5,13, da Turquia (TUR) é 2,31, do Uruguai (URU) é 2,14, e assim sucessivamente.

Finalmente, como houve a adaptação das escalas para apresentar graficamente a evolução dos IRS, a comparação quantitativa deve ser cuidadosa. Não obstante, a comparabilidade do comportamento das tendências entre os IRS é perfeitamente cabível.

Para facilitar o entendimento, todos os valores utilizados na elaboração dos gráficos dos países a seguir evidenciados estão expostos no apêndice 6 .

\subsubsection{Brasil - IRS}

Os gráficos 1 e 2 apresentam a evolução dos IRS para o Brasil, calculados com base nas três equações usadas para classificar os países quanto à suscetibilidade ou não à crise.

Em virtude da mudança nas regras de reconhecimento e mensuração dos créditos anormais, estabelecida pela Resolução 2.682, de 21 de dezembro de 1999, do Conselho Monetário Nacional, existem dois patamares distintos de risco sistêmico no setor bancário brasileiro, sendo a data limítrofe dezembro de $2000^{66}$. Não obstante a alteração no diferentes critérios, é nítida a diferença na volatilidade e nos valores dos indicadores entre os períodos.

O Gráfico 1 mostra o período até dezembro de 2000, quando o IRS apresenta valores superiores a zero e significativa volatilidade, evidenciando a maior suscetibilidade à crise. Esse período abrange os dois momentos em que o Brasil esteve na iminência da crise bancária, caso medidas tempestivas não tivessem sido adotadas acertadamente.

Os IRS 2 e 5, formados pelos indicadores MROE e MIRCRE, e DCAOC, respectivamente, apresentam picos em março de 1995 e junho de 1999, meses em que os efeitos das crises provocaram alterações distintas nas informações contábeis.

66. Apesar da edição de 21/12/1999, a norma passou a vigorar na prática em 2000. Como o estudo utiliza quatro períodos anteriores no cálculo dos indicadores, a primeira data sem influência do critério anterior é dezembro de 2000 . 


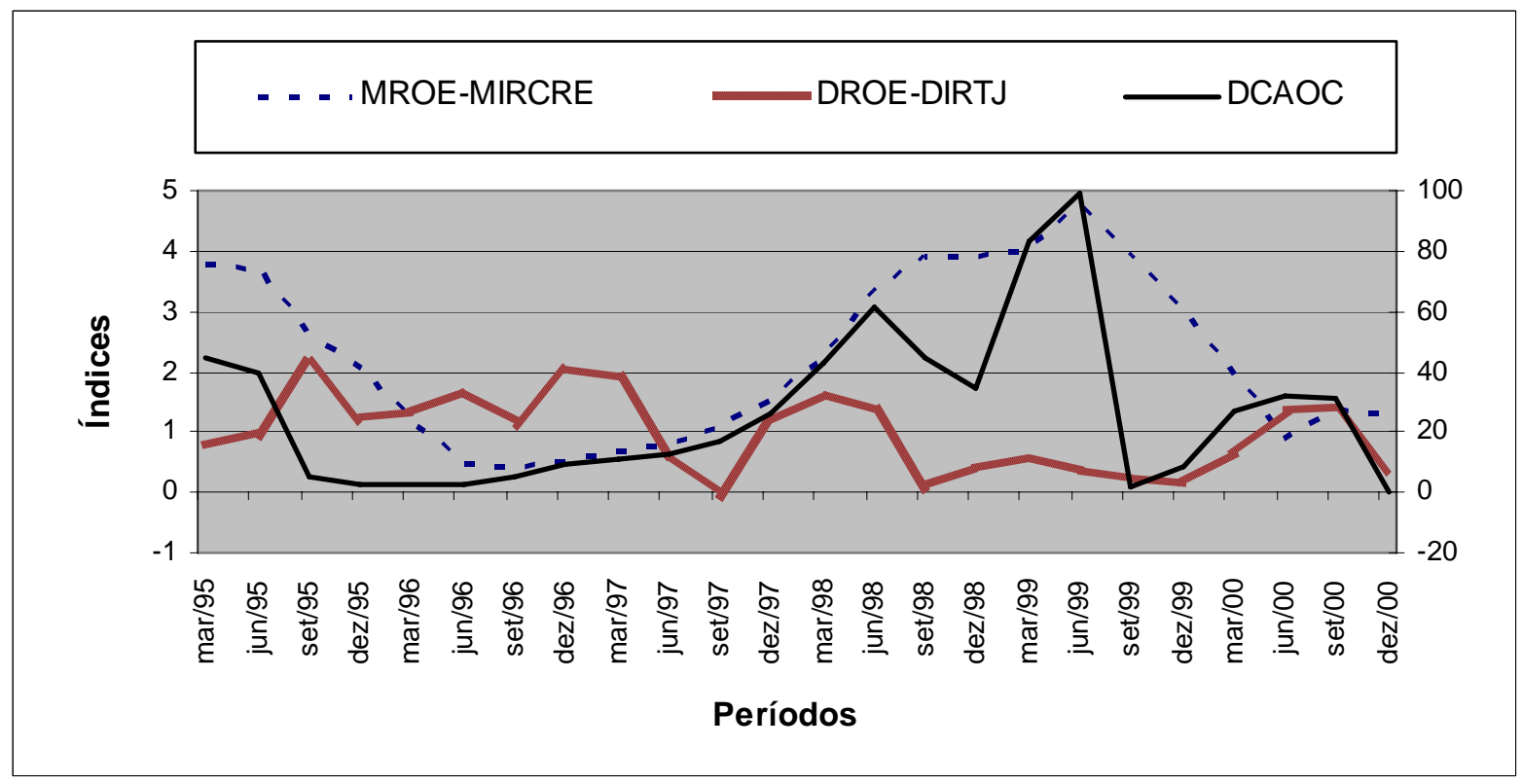

Gráfico 1 - Evolução dos índices de risco sistêmico no Brasil - mar/95 a dez/00

* A escala da linha DCAOC é à direita

Diferentemente, o IRS4, formado pelos indicadores DROE e DIRTJ, não apresenta picos coincidentes com os períodos identificados como início das crises. O comportamento parece antecipar os movimentos dos outros dois indicadores, como se as alterações no desvio-padrão da rentabilidade e da taxa de juros fossem prenúncios de alterações no risco de crédito, volume de créditos anormais e, por conseqüência, nos resultados.

A consulta aos dados mostrou que o motivo principal da discrepância entre o IRS4 e os IRS2 e IRS5, ocorrida no período da crise, entre dezembro de 1998 e junho de 1999, foi conseqüência dos exuberantes resultados positivos obtidos pelo sistema bancário nesses semestres, de 2,4 e 6,8 bilhões de reais, respectivamente, que aumentaram o patrimônio líquido em $43 \%$.

O Gráfico 2 mostra o período após dezembro de 2000, quando os IRS apresentam valores inferiores a zero, tendências decrescentes e volatilidades reduzidas, indicando menor suscetibilidade à crise. Nesse período, com a redução do risco sistêmico, o Brasil pode ser incluído no grupo dos países não-suscetíveis à crise no setor bancário.

A redução relativa no volume de ativos expostos ao risco de taxa de juros, proporcionalmente ao patrimônio líquido, e a constância nos resultados, causaram a diminuição no valor dos indicadores representativos do desvio-padrão da rentabilidade e da taxa de juros. 


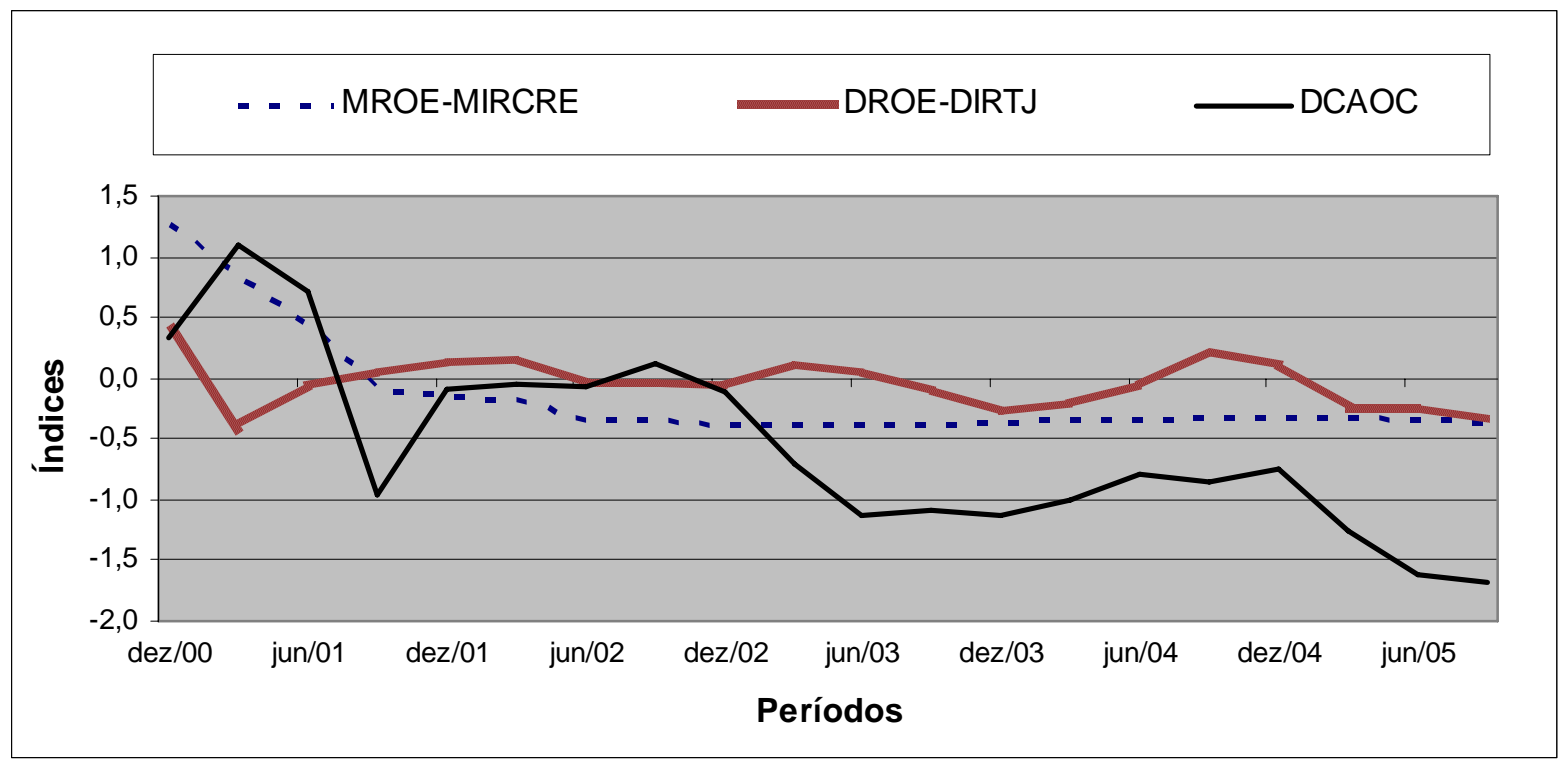

Gráfico 2 - Evolução dos índices de risco sistêmico no Brasil - dez/00 a set/05

Apesar disso, a posição dos IRS em relação à suscetibilidade à crise coincide com o nível de risco sistêmico observado no setor bancário brasileiro entre 1995 e 2005, confirmando a eficácia dos instrumentos de mensuração.

\subsubsection{Argentina - IRS}

O Gráfico 3 expõe a evolução dos IRS da Argentina e mostra claramente as duas crises ocorridas no período. Enquanto na data de março de 1995 salienta-se o IRS5, formado pelo indicador DCAOC, na crise de dezembro de 2001 todos os IRS apresentam crescimento.

Conforme mencionado, uma crise não tem data de início e fim exatos, tanto o processo de deterioração como de recuperação dos fundamentos econômicos e da situação econômicofinanceira do sistema financeiro são paulatinos, sendo que a recuperação necessita de ações planejadas e duradouras para realmente obter êxito.

No caso da Argentina, ficou evidente que as medidas adotadas para conter a primeira crise, marcada pelo pior momento em junho de 1995, não foram suficientes para evitar o ressurgimento dos problemas em magnitude muito maior. As diferenças entre as duas crises podem ser percebidas inclusive no próprio valor dos IRS. 


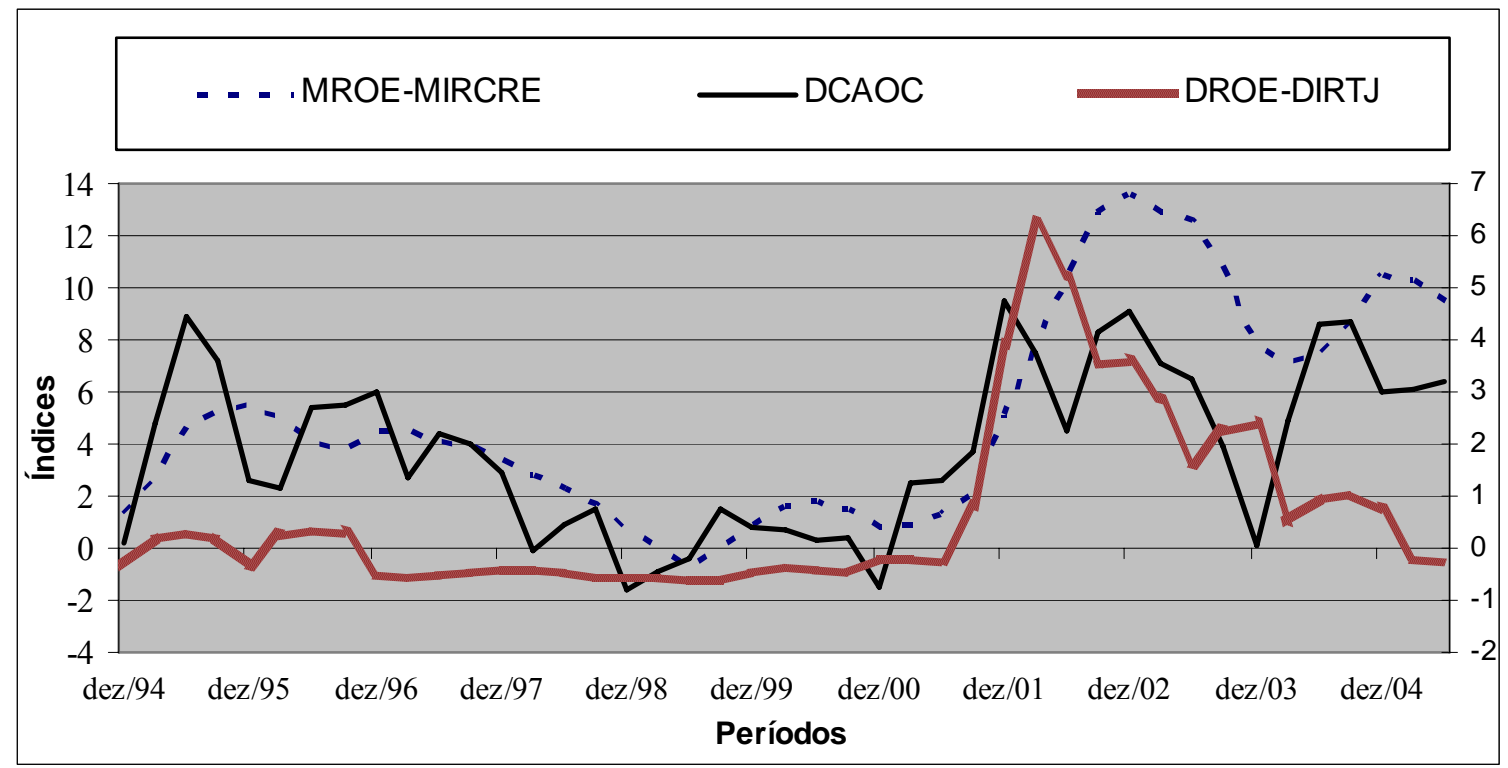

Gráfico 3 - Evolução dos índices de risco sistêmico na Argentina - mar/95 a jun/05

* A escala da linha DCAOC é à direita

Após o período de tranqüilidade, identificado pelos IRS próximos ou inferiores a zero, entre os meses de dezembro de 1998 e 2000, houve abrupta alteração nas tendências, indicando o recrudescimento do risco sistêmico no setor bancário, com o máximo dos efeitos nefastos identificados em dezembro de 2001 e dezembro de 2002.

Como é de conhecimento público, a falta de ações saneadoras e a opção do governo argentino em manter a paridade cambial culminaram em uma segunda crise, muito pior e mais grave que a primeira, obrigando inclusive ao abandono do regime de câmbio fixo, âncora do plano econômico então vigente.

Ainda em 2005, os IRS formados pelas variáveis contábeis representativas da qualidade do crédito continuam em nível bastante elevado, com necessidade de manutenção das medidas que reduzam o risco sistêmico no setor bancário.

A divergência entre o IRS4 e os IRS2 e IRS5, particularmente na crise de 1995, ocorreu em termos da magnitude das alterações. Enquanto os dois primeiros apresentaram significativo aumento indicando a crise, o IRS4 apresentou pequena evolução, cruzando levemente a linha divisória de suscetibilidade à crise. Essa constatação está consistente com a classificação indevida por este indicador apresentada na Tabela 35. 


\subsubsection{México - IRS}

A análise da evolução dos IRS do México, expostos no Gráfico 4, depois da crise de dezembro de 1994, demonstra que o país está com elevado risco sistêmico no setor bancário.

Após curto período de risco sistêmico em nível baixo, entre setembro de 1995 e dezembro de 1996, a média e a volatilidade da rentabilidade, a média de risco de crédito, e a volatilidade da taxa de juros e dos créditos anormais atingem valores acima de padrões considerados normais.

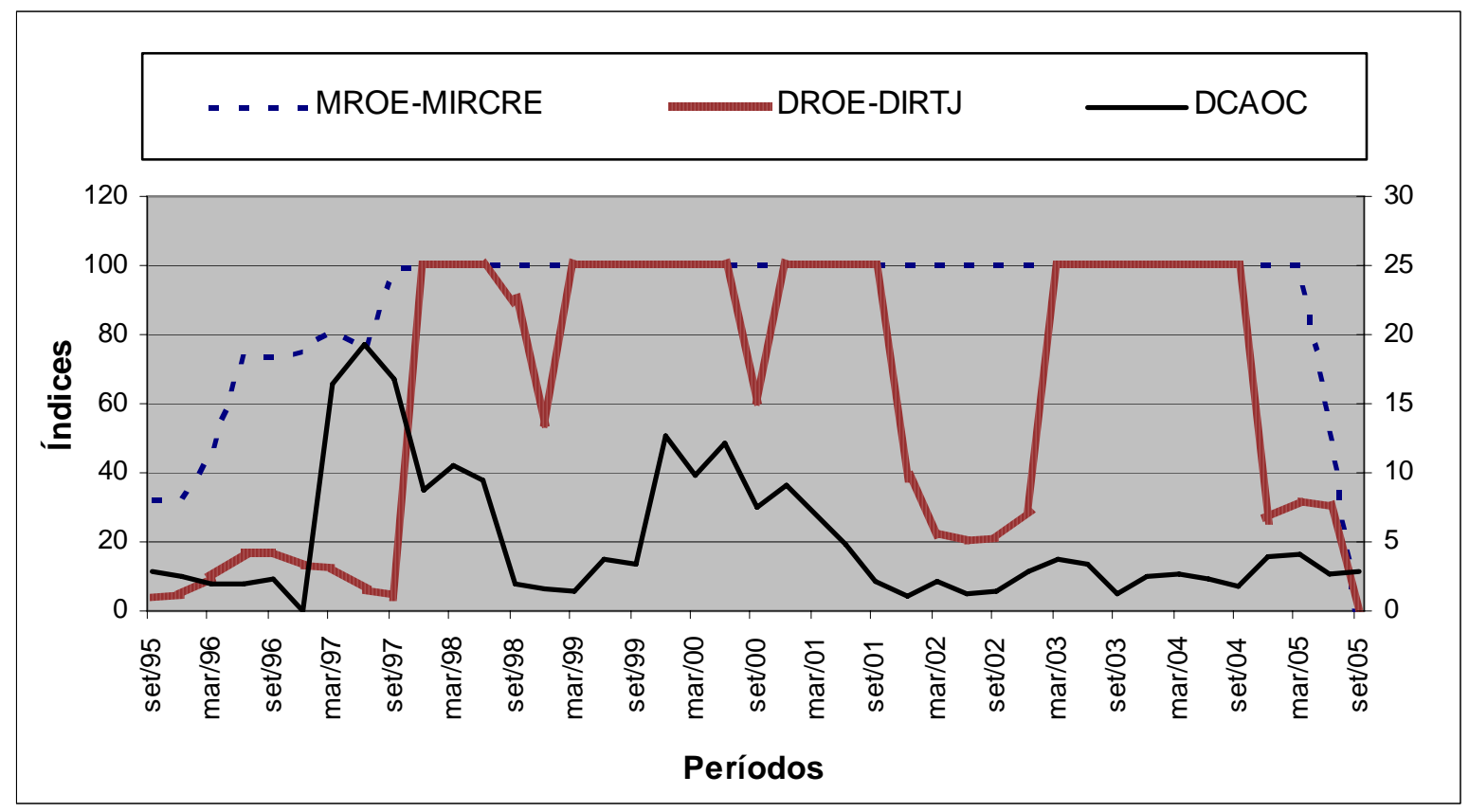

Gráfico 4 - Evolução dos índices de risco sistêmico no México - set/95 a set/05 A escala da linha DCAOC é à direita.

A justificativa da anormalidade dos indicadores está nos resultados negativos, em praticamente todo o período, e no patrimônio líquido contábil a descoberto, em diversos trimestres a partir de março de 1999, apresentados pelo sistema bancário mexicano.

Frente a isso, para fins de visualização gráfica, houve a necessidade de limitar o valor dos índices calculados pelas equações, especialmente as que utilizam os indicadores MROE e MIRCRE e DROE e DIRTJ.

Somente a partir de junho de 2003 e dezembro de 2004, o patrimônio líquido e os resultados voltaram a ser positivos de forma consistente. Os IRS confirmam a tendência declinante no risco sistêmico a partir de dezembro de 2004. 


\subsubsection{Rússia - IRS}

A crise experimentada pela Rússia, com início em setembro de 1998, é fortemente identificada pelas três linhas representativas dos IRS, apresentadas no Gráfico 5.

O IRS5, composto pelo desvio dos créditos anormais, sinaliza o aumento do risco sistêmico a partir de setembro de 1997, um ano antes da crise. Da mesma forma, os outros dois IRS também acusam aumento do risco a partir de março de 1998.

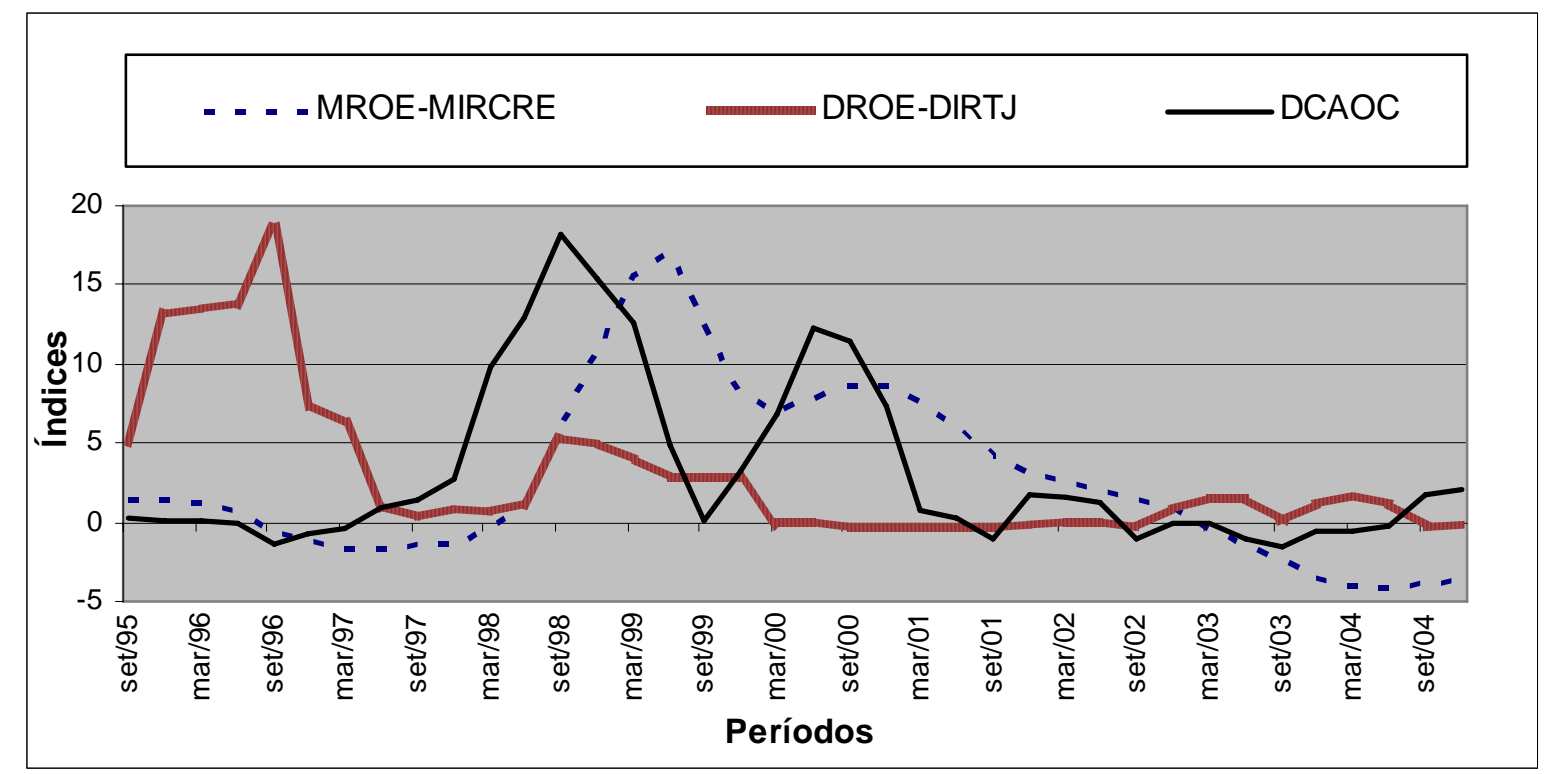

Gráfico 5 - Evolução dos índices de risco sistêmico na Rússia - set/95 a dez/04

Anteriormente à data da crise, salienta-se o IRS4, composto pelos indicadores DROE e DIRTJ. A verificação dos dados revela que a taxa de juros na Rússia era de três dígitos até setembro de 1995 , tendo atingido o valor máximo de 435\% ao ano, em março de 1995 . Isso mostra que, em situações de hiperinflação, o nível de risco sistêmico é naturalmente elevado, pois a magnitude dos desvios-padrão é maior.

Mediante a redução na taxa de juros para níveis praticados em economias sem hiperinflação, os IRS crescem à medida que a crise se aproxima. O IRS4 e o IRS5, formados pelos indicadores DROE e DIRTJ, e DCAOC, respectivamente, atingem o ápice em setembro de 1998, enquanto o IRS2, formado pelos indicadores MROE e MIRCRE, mantém a escalada crescente até setembro de 1999. 
Observa-se também, no Gráfico 5, que o processo de recuperação e redução do risco sistêmico no setor bancário russo foi lento, estendendo-se por três anos. A consistência na tendência decrescente do risco sistêmico somente é atingida a partir de março de 2001.

Aparentemente, as medidas adotadas pela autoridades russas surtiram os efeitos desejados para reduzir o nível de risco bancário sistêmico. A melhora, inclusive, permite classificar o sistema bancário como não-suscetível à crise entre dezembro de 2002 e junho de 2004, quando há um repique na volatilidade dos créditos anormais, indicando provável problema.

\subsubsection{Islândia - IRS}

Com vistas a elucidar o motivo da classificação indevida da Islândia, apontada pelas três equações, a análise do Gráfico 6 confirma a explicação da classificação inicial errônea no grupo dos países sem crise.

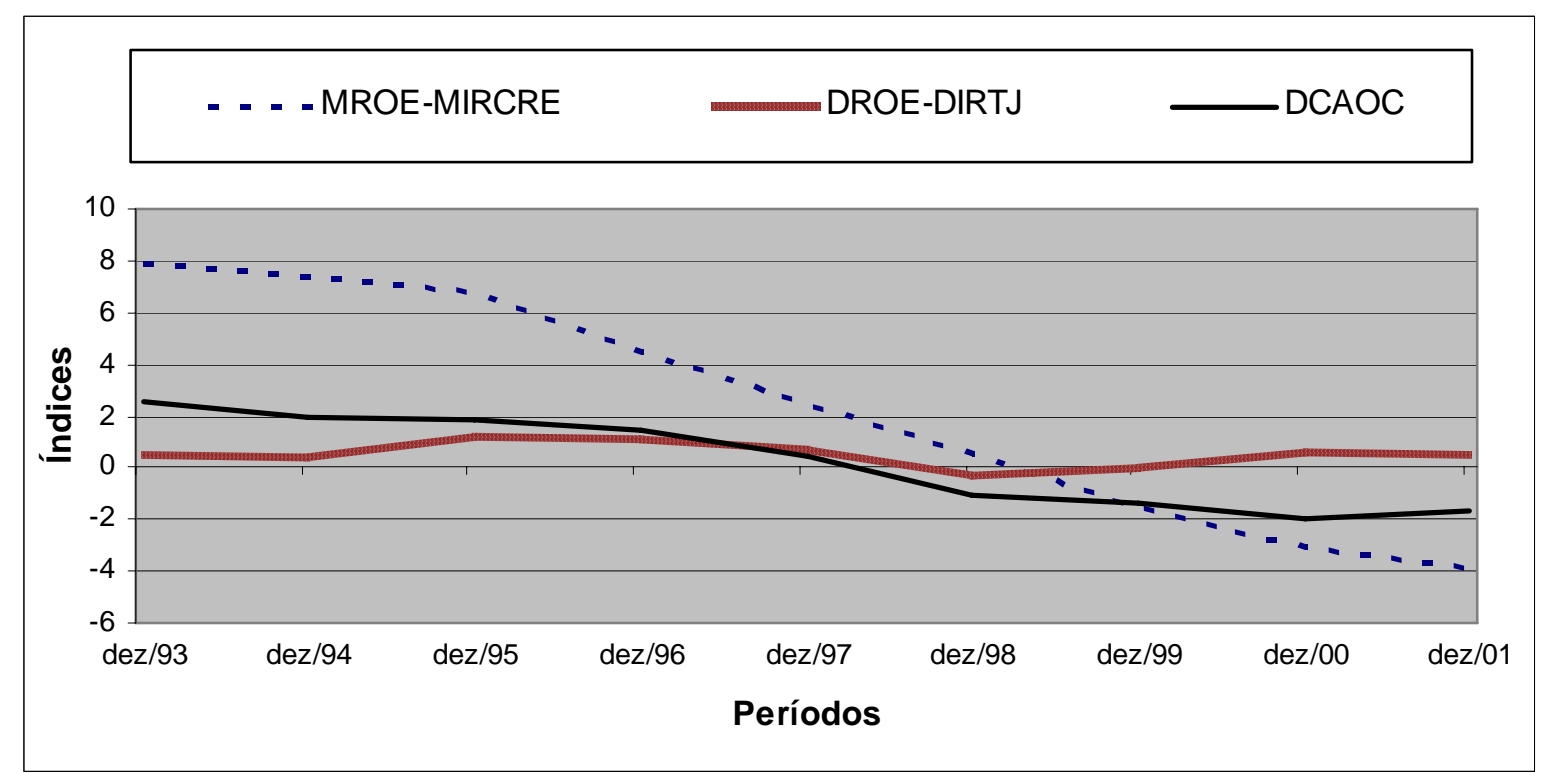

Gráfico 6 - Evolução dos índices de risco sistêmico na Islândia - dez/93 a dez/01

Concomitantemente aos demais países nórdicos, com dados analisados pela regressão logística, a Islândia sinalizava elevado risco sistêmico no período até dezembro de 1997, quando então passou a apresentar IRS declinantes.

Assim, em virtude da não segregação dos períodos, como realizado na Dinamarca, Finlândia, Noruega e Suécia, a técnica classificou acertadamente a Islândia como suscetível à crise. Os 
IRS, com valores superiores a zero, mostram claramente o maior risco sistêmico do sistema bancário islandês até essa data.

Após dezembro de 1999, há diferença entre a sinalização dos IRS2 e IRS5, e do IRS4. Enquanto os primeiros indicam não-suscetibilidade à crise e risco sistêmico reduzido, o último apresenta tênue viés crescente e retorna o sistema bancário da Islândia à situação de maior risco. Não obstante, as linhas tendem a convergir para um valor próximo a zero.

\subsubsection{Tailândia - IRS}

Assim como a Islândia, a Tailândia foi classificada em grupos trocados pelas equações que utilizam as médias da rentabilidade e do risco de crédito e o desvio-padrão dos créditos anormais.

A observação do Gráfico 7 permite concluir que o motivo foi a falta de reconhecimento dos créditos anormais no período que antecede a crise de dezembro de 1997.

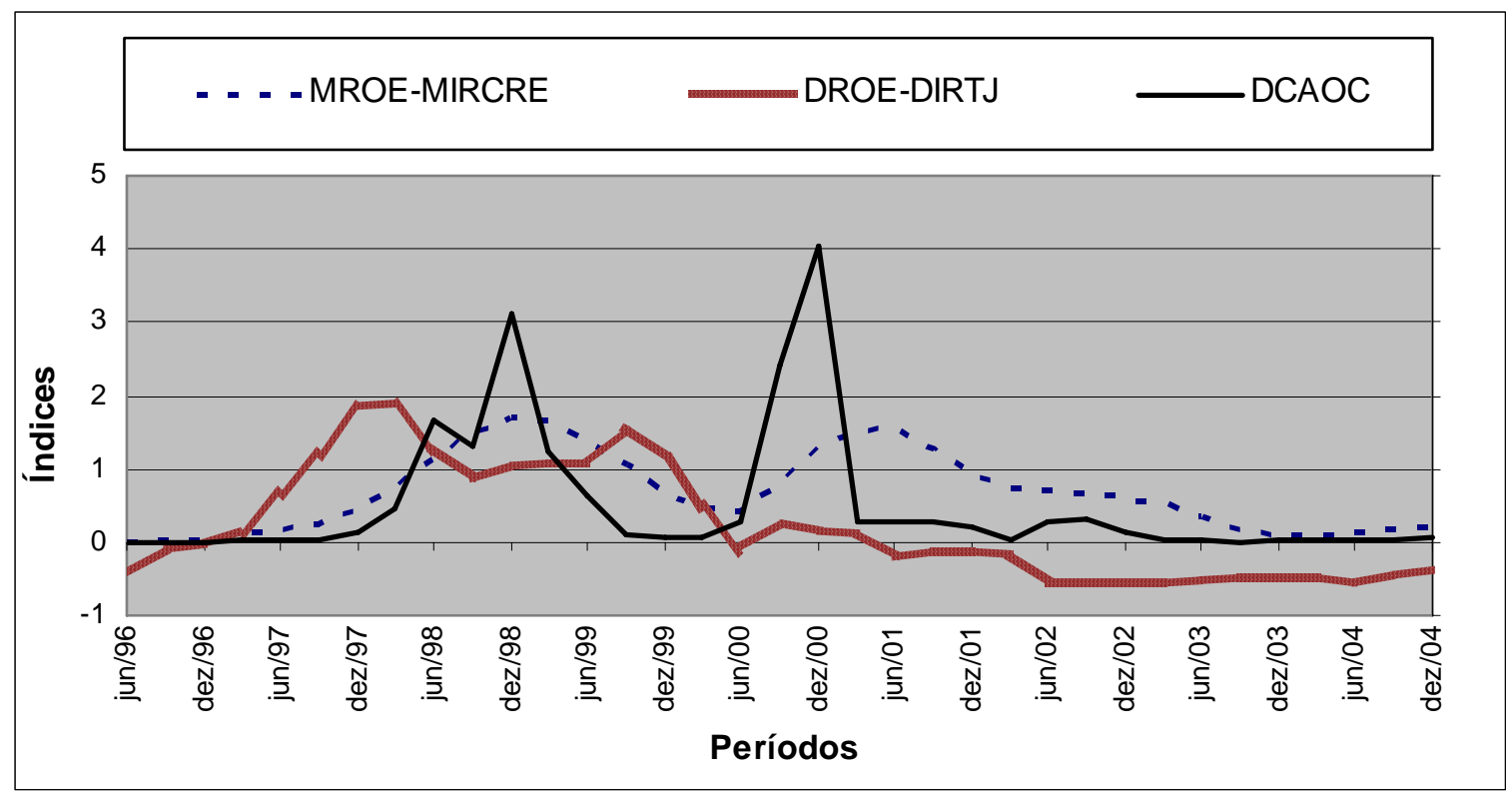

Gráfico 7 - Evolução dos índices de risco sistêmico na Tailândia - jun/96 a dez/04

Ante à omissão, os IRS formados pelos indicadores representativos da qualidade do crédito não apresentaram alterações que sinalizassem o maior risco sistêmico. Sem os registros contábeis corretos não houve como refletir os riscos. 
A comprovação está no reconhecimento dos créditos anormais logo após a eclosão da crise. A variabilidade dos IRS pós-crise indica que o sistema passou a reconhecer os problemas na realização dos créditos em etapas, marcadamente entre as datas de dezembro de 1997 e março de 2001.

Somente o IRS calculado com base nos indicadores representativos dos desvios-padrão da rentabilidade e da taxa de juros (DROE e DIRTJ) sinalizou o aumento do risco sistêmico antes da crise, permanecendo elevado até setembro de 1999, quando começou a decrescer.

Apesar de alguns resquícios na qualidade do crédito, pode-se avaliar o sistema bancário tailandês com risco sistêmico reduzido após dezembro de 2002, quando os IRS tendem ou estão abaixo de zero.

\subsubsection{Suécia - IRS}

Conforme comentado na análise da Islândia, a Suécia é um dos países nórdicos afetados pela crise bancária iniciada em 1991 e com efeitos percebidos até dezembro de 1996. O Gráfíco 8 mostra os elevados níveis dos IRS nesse período.

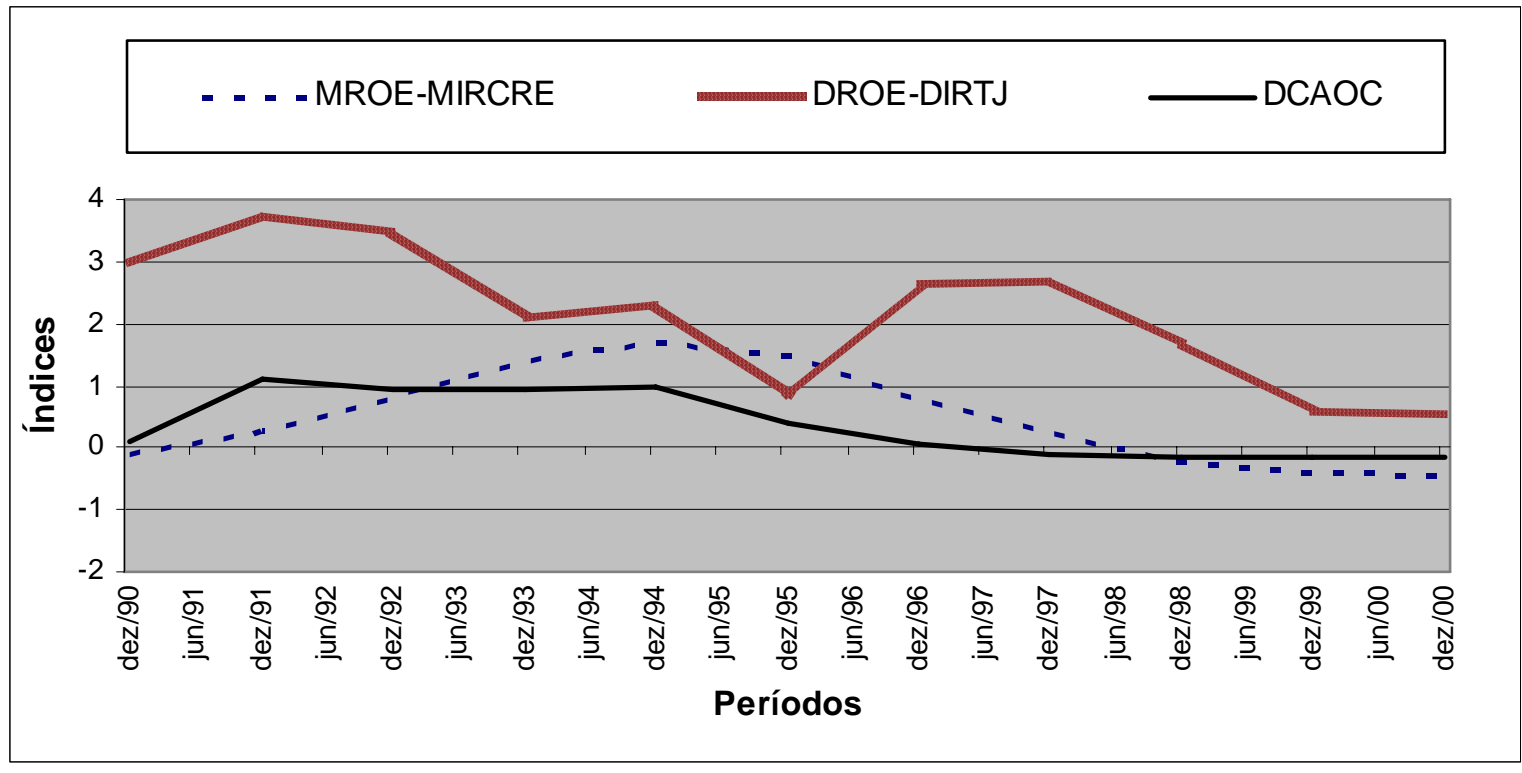

Gráfico 8 - Evolução dos índices de risco sistêmico na Suécia - dez/90 a dez/00

A tendência decrescente no risco sistêmico ocorre a partir de dezembro de 1995, para os IRS2 e IRS5, relacionados às médias do risco de crédito e da rentabilidade e ao desvio-padrão da 
inadimplência, respectivamente, e após dezembro de 1997, para o IRS4, relacionado aos desvios-padrão da taxa de juros e da rentabilidade.

Após dezembro de 1998, o sistema bancário sueco atinge o nível de risco sistêmico considerado não-suscetível à crise. Isso permite inferir que houve a adoção de medidas capazes de debelar as causas da crise sistêmica experimentada.

Por esse motivo, os dados incluídos na análise de regressão são posteriores a junho de 1997, com vistas a isolar possíveis conseqüências ainda remanescentes no sistema. Dessa forma, a Suécia foi classificada como não-suscetível à crise pelas três equações.

\subsubsection{Reino Unido - IRS}

Para os anos de 1990, o Gráfico 9 evidencia a tendência decrescente no nível de risco sistêmico no Reino Unido, com redução dos IRS para valores inferiores a zero.

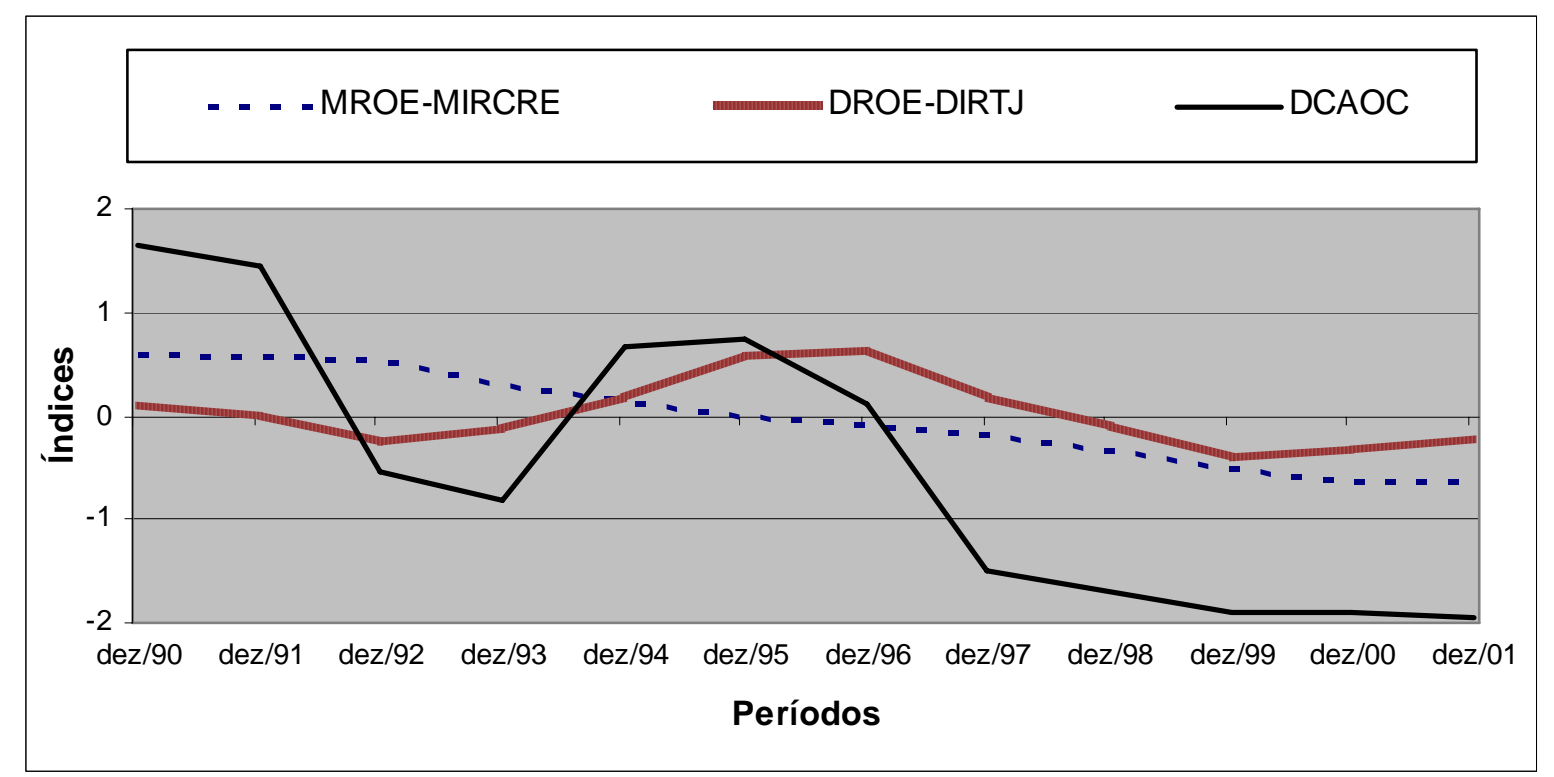

Gráfico 9 - Evolução dos índices de risco sistêmico no Reino Unido - dez/90 a dez/01

A menor volatilidade nos indicadores de risco e o aumento nos de rentabilidade confirmam a classificação atribuída pelas três equações no grupo não-suscetível à crise.

Entre dezembro de 1991 e dezembro de 2001, o índice de risco de crédito, em relação ao patrimônio líquido, despencou de 21,45\% para 2,3\%, o desvio-padrão dos créditos anormais 
caiu de 3,3 para 0,5 , e a rentabilidade aumentou de 4,3\% para $18,5 \%$. Todos esses aspectos favoráveis resultaram em expressiva redução no risco do sistema bancário.

O único ponto de preocupação no período foi o aumento isolado no desvio-padrão da taxa de juros, chegando a 5,15 em dezembro de 1996, mas voltando a 0,5 em dezembro de 2000.

Ante o exposto, não há dúvidas de que o Reino Unido está acertadamente classificado como não-suscetível à crise após essa data.

\subsubsection{Austrália - IRS}

A análise do Gráfico 10 permite concluir que o sistema bancário australiano apresentou reduzido risco sistêmico durante toda a década de 1990.

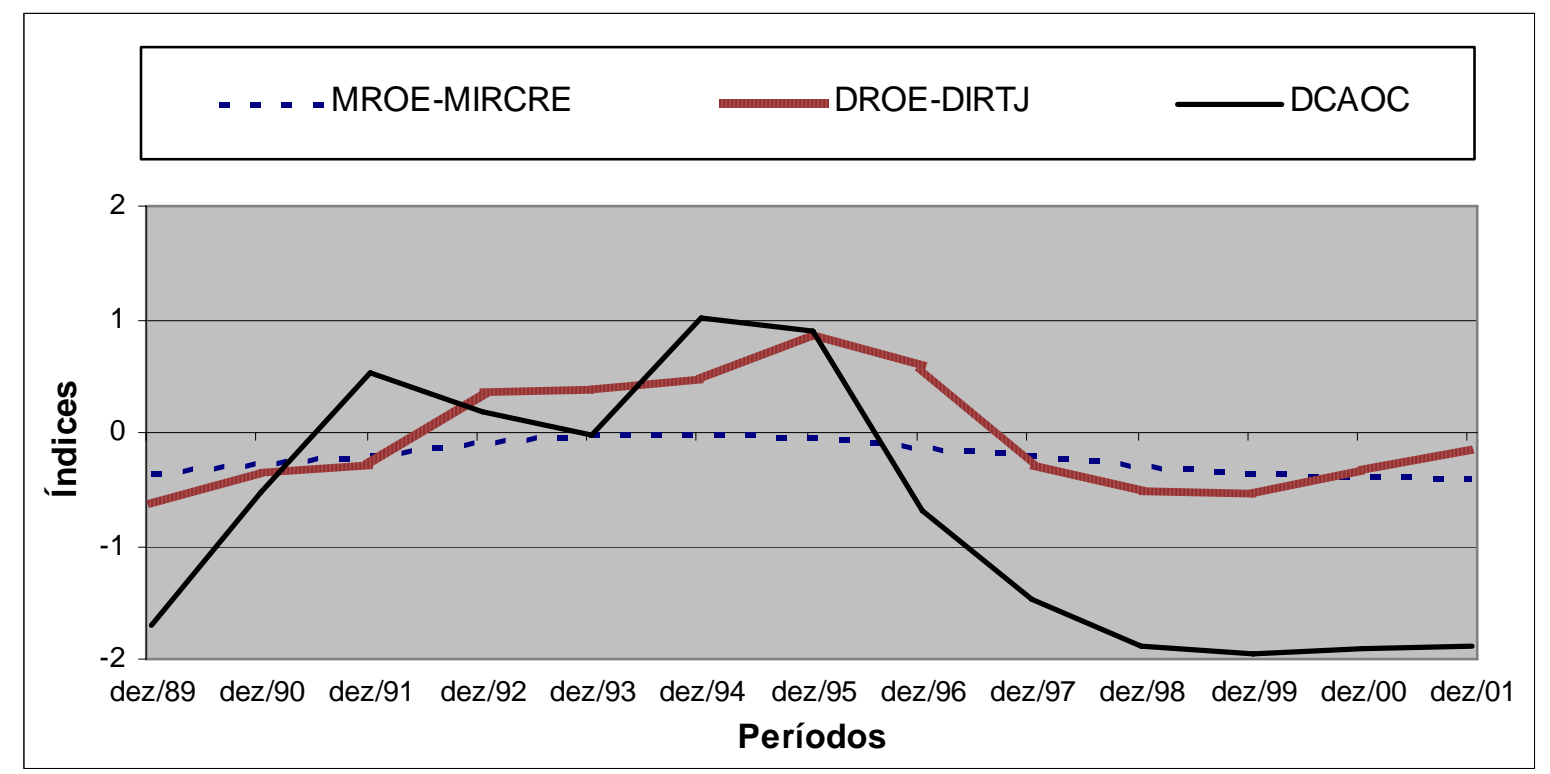

Gráfico 10 - Evolução dos índices de risco sistêmico na Austrália - dez/89 a dez/01

Como no Reino Unido, entre 1994 e 1995, houve elevação nos IRS, indicando aumento no nível de risco sistêmico. O motivo foi o aumento no indicador de risco de crédito e o prejuízo apresentado pelo sistema em 1992, que repercutiu no cálculo do desvio-padrão dos três anos seguintes. Excetuando-se o curto período citado, o sistema bancário da Austrália está corretamente classificado como não-suscetível à crise no período sob análise. 


\subsubsection{Estados Unidos - IRS}

Após os problemas ocorridos no sistema de poupança e empréstimo americano (savings and loans companies), ao final dos anos de 1980, o sistema bancário americano demonstra baixo risco sistêmico durante toda década de 1990.

Os IRS inferiores a zero desde 1993, visualizados no Gráfico 11, indicam que o volume de créditos anormais é baixo e não há variabilidades significativas nas taxas de juros e nos resultados. Aliás, nesse período, as taxas de juros apresentam tendência de queda e os resultados aumentaram, com a média da rentabilidade do patrimônio líquido variando de 4,8\%, em 1990, para 14\% em 2000.

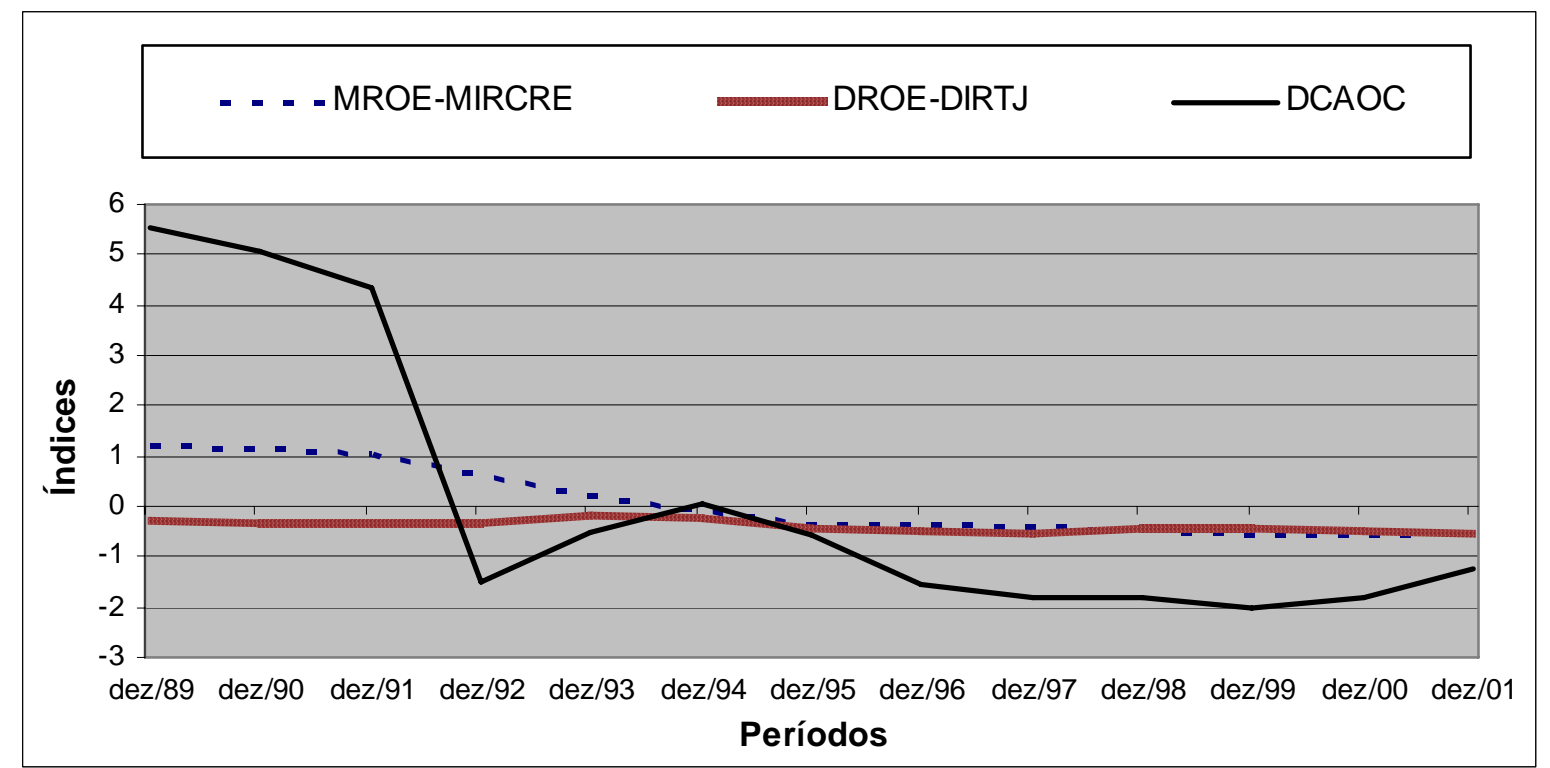

Gráfico 11 - Evolução dos índices de risco sistêmico nos Estados Unidos - dez/89 a dez/01

Ante o exposto, o sistema bancário americano pode ser considerado como de baixo risco sistêmico e ser classificado como não-suscetível à crise a partir de 1992.

\subsubsection{Considerações sobre a aplicação das equações}

A aplicação das equações em períodos diferentes daqueles utilizados no cálculo apresentou resultados satisfatórios. A regra de classificação diferenciou os países e os períodos no tocante à suscetibilidade ou não à crise.

Enquanto alguns países apresentaram risco sistêmico constante em quase todo o período, outros alternaram as situações, interpolando a classificação do país de acordo com os índices 
obtidos. Nesse aspecto, os três índices apresentaram coerência em quase todas as classificações.

As pequenas divergências, quando existiram, foram decorrentes da magnitude ou da omissão da informação no valor dos indicadores. De qualquer forma, haja vista à complementaridade dos índices, a prudência recomenda utilizá-los conjuntamente, pois caso alguma característica importante não seja apontada em um dos índices de risco sistêmico, é bastante provável que os outros a identifiquem.

A comparação com os fatos ocorridos demonstra que os índices são eficazes para classificar os sistemas bancários de acordo com o nível de risco sistêmico. Essa funcionalidade possibilita diagnosticar a situação e adotar medidas adequadas ao nível de risco sistêmico e direcionadas para os aspectos causadores. 


\section{CONCLUSÃO}

O objetivo de mensurar o nível de risco sistêmico no setor bancário dos países da amostra foi atingido. Os testes estatísticos realizados com a regressão logística comprovaram a existência de indicadores contábeis e de riscos capazes de discriminar os sistemas bancários como suscetíveis e não-suscetíveis a crises. As equações apresentaram percentuais de acerto nas classificações superiores a $90 \%$.

Conjuntamente à correta separação dos grupos, as classificações dos países são estabelecidas em percentuais que expressam a probabilidade de pertencer a determinado grupo. $\mathrm{O}$ ordenamento dos países pelo grau de risco sistêmico fornece parâmetros relevantes de comparação, propiciando a tomada de decisão calibrada à exigência de cada situação. Por meio dele, é possível saber qual país apresenta maior ou menor risco sistêmico no setor bancário.

Em adição, o acompanhamento dos IRS de um país no tempo expõe as tendências e os pontos críticos longitudinalmente, os quais permitem análises e alterações no rumo das políticas que visam ajustar o crescimento e o desenvolvimento do sistema bancário à estratégia econômica implantada.

Apesar da metodologia de formulação das equações que geram os IRS utilizarem as características dos momentos que antecedem as crises, a significativa contribuição do instrumento não é a previsão de crises, mas sim o conhecimento do nível de risco sistêmico, a fim de que medidas tempestivas possam ser adotadas para reduzi-lo. Subsidiariamente, como a crise representa o estresse do risco sistêmico, a função de prever está implícita.

Em face da inexistência de um limite a partir do qual um sistema é considerado em crise, os IRS não contêm valores absolutos para indicar essa situação. Existe apenas um ponto de corte que segrega os países e os períodos quanto à suscetibilidade ou não à crise. Por isso, a interpretação deve ser relativa e depende da comparação com outros períodos e países.

As aplicações das equações sobre os dados de países pertencentes a ambos os grupos e em períodos distintos, expostas graficamente no capítulo anterior, exemplificam o aspecto 
relacional dos IRS. Demonstram ainda a fidelidade do comportamento dos IRS com os períodos de tranqüilidade e de maior risco sistêmico, inclusive em situações diversas daquelas que compõem a amostra.

Os resultados satisfatórios são explicados pela diversidade e qualidade das informações contidas nos indicadores testados, pela robustez e adequação da técnica estatística empregada e, principalmente, pela existência de características comuns nos momentos que antecedem as crises, mas diferenciadas em situações normais. Todas essas qualificações contribuíram para a formulação de regras de classificação aplicáveis indistintamente em qualquer um dos países no período após 1990.

A capacidade de mensurar o risco sistêmico, independentemente do tempo ou da localização do sistema bancário, consubstancia o atributo essencial para utilização dos IRS de forma generalizada. Diferentemente dos modelos de previsão de insolvência, usualmente condicionados a restrições conjunturais de determinado país ou período, os IRS propostos são resultantes de informações das crises mais relevantes ocorridas nos anos de 1990, compreendendo diferentes países e períodos que ampliam bastante o espectro para sua aplicação.

Outra contribuição significativa apresentada pelos modelos é identificar os indicadores que estão provocando as alterações indesejáveis, possibilitando a administração de medidas específicas e delimitadas sobre as variáveis que os compõem.

As variáveis contábeis e econômicas mais associadas à ocorrência de crises estão relacionadas com a qualidade dos créditos, o volume de resultados e o nível de taxa de juros. Todos os indicadores construídos com base nessas variáveis foram identificados como relevantes no processo de classificação, destacando-se os referentes à volatilidade da inadimplência, da rentabilidade e da taxa de juros, e à média da rentabilidade e do risco de crédito.

Nesse particular, ressalta-se a importância da informação contábil. Quatro dos cinco indicadores considerados significativos na discriminação dos grupos são puramente contábeis. Somente o índice de risco da taxa de juros, que utiliza a volatilidade de uma variável econômica sobre a posição contábil, aparece como estatisticamente significativo no conjunto. 
Nota-se também que outros indicadores demonstram capacidade de diferenciar os grupos, como a relação entre o ativo total e o patrimônio líquido, a posição líquida em moeda estrangeira e o risco de câmbio. Apesar de significativos, não foram usados porque apresentam correlação com os indicadores anteriores, não sendo admissível integrar a mesma equação. $\mathrm{O}$ critério de escolha para exclusão de um indicador correlacionado baseou-se no percentual de acerto na classificação, permanecendo aqueles com resultado mais elevado.

Essa limitação, entretanto, não invalida a utilização das equações formadas por esses indicadores isoladamente, podendo inclusive ser conveniente em determinadas circunstâncias, na medida em que agregam informações complementares. $\mathrm{O}$ único cuidado é o percentual de acerto menor que aumenta a possibilidade de erro na classificação de algum país.

A constatação da relevância de indicadores de risco na avaliação de sistemas bancários implica em novos desafios à contabilidade. É premente a necessidade de aumentar a quantidade e a qualidade de informações sobre os riscos inerentes às atividades operacionais nas demonstrações contábeis, especialmente das instituições financeiras.

A evidenciação das exposições líquidas em taxas de juros e de câmbio, bem como dos detalhes sobre a composição da liquidez e a mitigação da estrutura de crédito, abrangendo inclusive os instrumentos derivativos, tanto no balanço patrimonial como nos quadros anexos às notas explicativas, são imprescindíveis para mensurar o nível de risco sistêmico. A maior transparência dessas informações proporciona a redução de incertezas e a avaliação mais acurada dos riscos.

Nessa linha, a citação constante no pronunciamento de posse do novo presidente do Conselho Consultivo do IASB (CARVALHO, 2005) é bastante apropriada:

\footnotetext{
Nossa primeira tarefa, na verdade, a tarefa de qualquer um imbuído da responsabilidade de estabelecer padrões para o mundo dos negócios, é reduzir a incerteza [grifo nosso]. A questão é saber como cumprir isto; a resposta, apesar de difícil de atingir, é fácil de identificar evidenciação e transparência [grifo nosso]. ${ }^{67}$
}

67. Tradução livre de "Our very first task, indeed, the task of everyone involved in the standard-setting responsibilities in the business world, is therefore to reduce the unknown. The question is how to accomplish that; the answer, albeit tough to achieve, is easy to identify-disclosure and transparency." 
Ainda sobre os dados contábeis, salienta-se a imprescindibilidade da qualidade para obtenção de resultados fidedignos e utilizáveis. A obediência aos fundamentos contábeis deve ser observada em todo processo de reconhecimento, mensuração e evidenciação. Quanto melhor a qualidade, maior a capacidade de prover informações úteis.

A credibilidade dos dados coletados junto aos órgãos de supervisão e organismos internacionais foi determinante à construção de indicadores que expressassem adequadamente a situação econômico-financeira e os riscos inerentes às atividades operacionais do sistema bancário, propiciando, subseqüentemente, a obtenção de resultados satisfatórios.

A importância atribuída pelo estudo ao acompanhamento do risco sistêmico não deve significar que o monitoramento dos riscos individuais é substituível. A intenção é incorporar os instrumentos de mensuração do risco em todo o sistema aos já existentes para as instituições individualmente, com vistas a proporcionar melhores condições à gestão sistêmica.

Nesse sentido, as ações sobre os indivíduos provocam efeitos colaterais e precisam ser avaliadas conjuntamente, pois as conseqüências dos riscos individuais não alcançam a magnitude daquelas advindas do risco sistêmico.

Em termos estatísticos, a utilização da análise de regressão mostrou-se perfeitamente adequada aos objetivos do estudo. A técnica identificou os indicadores significativos e encontrou os coeficientes capazes de classificar os países em grupos distintos.

Invariavelmente, os testes da regressão logística sobre os indicadores representativos dos coeficientes de variação, das médias e dos desvios-padrão resultaram em modelos estatisticamente válidos, com elevado percentual de acerto na classificação.

Outrossim, os testes com indicadores contábeis e de riscos em separado foram igualmente satisfatórios, sem, contudo, apresentar resultados melhores do que os testes com todos os indicadores, descartando-se assim essa alternativa.

A principal dificuldade no tratamento estatístico residiu na identificação de indicadores significativos conjuntamente. Poucos indicadores apresentaram significância quando testados 
junto com outros. Somente após sucessivas exclusões de indicadores do modelo, a regressão logística conseguiu selecionar os indicadores com significância estatística e coeficientes diferentes de zero. A persistente causa foi a elevada correlação dos indicadores com significância estatística.

Complementarmente, a aplicação da estatística descritiva e da matriz de correlação retornou informações úteis sobre as características distributivas dos indicadores e das correlações existentes. Com base nesses resultados, houve o direcionamento na escolha dos indicadores que deveriam permanecer nos testes de regressão logística.

Em síntese, assim como os estudos sobre as crises monetárias e bancárias, empregando exclusivamente variáveis econômicas, apontam as variações nas reservas internacionais, na taxa de câmbio e no nível de endividamento externo de curto prazo como relevantes na previsão dessas crises, o presente estudo demonstrou a existência de indicadores formados por variáveis contábeis capazes de mensurar eficazmente o risco sistêmico no setor bancário.

A comprovação está na significativa associação entre as informações extraídas da contabilidade e o nível de risco sistêmico. Nos períodos que antecedem as crises bancárias, os indicadores contábeis comportam-se diferentemente, demonstrando a existência de similaridades entre os países que sofreram as crises, especialmente na qualidade dos créditos, nos resultados e na exposição ao risco de taxa de juros.

Enquanto as variáveis econômicas avaliam os riscos sob a ótica macroeconômica das contas nacionais do país, as variáveis contábeis possibilitam avaliar o risco em determinado setor. Essa discricionariedade permite a adoção de medidas diferenciadas, pois nem todos apresentam as mesmas vulnerabilidades e podem ser saneados com medidas genéricas, do tipo "one fits all".

A intensidade da crise no sistema bancário é condicionada ao volume e à característica da exposição dos bancos conjuntamente. Por isso, os IRS mensuram o risco sistêmico em cada país considerando o montante exposto, a volatilidade das variáveis que causam o risco e o patrimônio líquido existente para suportar as variações resultantes. 
Finalmente, a incorporação de instrumentos para mensurar e mapear o risco sistêmico antecipa o conhecimento das vulnerabilidades e propicia o direcionamento dos recursos com mais eficiência.

\subsection{Considerações finais}

Os resultados satisfatórios apresentados no estudo não esgotam o assunto. Pelo contrário, a conclusão instiga à realização de novas pesquisas sobre o risco sistêmico, apontando para um amplo espectro de oportunidades na área contábil. A contabilidade ainda tem muito a oferecer para o entendimento deste complexo fenômeno.

A título de sugestão, a conjugação de variáveis contábeis com valores de riscos obtidos das variáveis econômicas, bem como a inserção da volatilidade nos cálculos dos indicadores, parece ser um novo caminho de pesquisa. Indicadores contábeis, formados sob esse conceito, poderiam ser igualmente testados com outras informações consideradas relevantes, tais como as provenientes do mercado de capitais, a fim de identificar o grau de associação.

Quanto às causas do risco sistêmico, as abordagens são ilimitadas. Estudos empíricos para verificar como ocorre a propagação das crises, identificando as variáveis determinantes do "efeito-contágio", assim como a participação do sistema de pagamentos nesse processo, representam desafios a serem transpostos para melhorar a compreensão e o domínio do risco.

Outro item ainda pouco explorado academicamente é o risco operacional. A vasta quantidade de variáveis envolvidas no conceito, ainda não definidas e identificadas completamente, somada à ausência de métricas à adequada aferição, constituem obstáculos para integrar esse componente do risco no processo de avaliação.

E, finalmente, com o pensamento voltado à continuidade deste estudo, a obtenção de dados individuais das instituições financeiras, de países suscetíveis ou não a crises, possibilita a realização de análises que considerem as correlações nas posições individuais, assim como o grau de concentração no sistema. A verificação da correlação e da concentração existente pode desvendar aspectos ainda não compreendidos na mensuração do risco sistêmico. 


\section{REFERÊNCIAS}

ADES, Alberto; MASIH, Rumi; TENENGAUZER, Daniel. Gs-Watch: a new framework for predicting financial crisis in emerging markets. New York: Goldman Sachs, 1998.

AGÉNOR, Pierre-Richard; BHANDARI, Jagdeep.S; FLOOD, Robert P. Speculative attacks and models of balance-of-payments crises. Working Papers. Cambridge, MA: National Bureau of Economic Research - NBER, n. 3919, 1991.

ALBUQUERQUE Jr. J. Avaliação dos indicadores de predição de insolvência bancária no Brasil para os períodos de 1994/5 e 1997/98. Rio Grande do Sul, 2000. Dissertação (Mestrado). Universidade Federal do Rio Grande do Sul - UFRGS.

ALLEN, Franklin; GALE, Douglas. Optimal financial crises. Journal of Finance, v. 53, n. 4, p. 1245-1284, 1998.

ALLEN, Franklin; GALE, Douglas. Financial contagion. Journal of Political Economy, v. 108, n. 1, p. 1-33, fev. 2000.

ALTMAN, Edward I. Financial ratios, discriminant analysis and the prediction of corporation bankruptcy. Journal of Finance, v. 23, n. 4, p.589-609, set. 1968.

ALTMAN, Edward I. Zeta analysis, a new model to identify bankruptcy risk of corporations. Journal of Banking and Finance, v. 1, n. 6, p.29-51, 1977.

ANDRADE, Maria Margarida de. Como preparar trabalhos para cursos de pósgraduação. $5^{\text {a }}$ ed. São Paulo: Atlas, 2002.

ASSAF NETO, Alexandre. Estrutura e análise de balanços: um enfoque econômicofinanceiro. $5^{\text {a }}$ ed. São Paulo: Atlas, 2000.

BANCO CENTRAL DO BRASIL. Boletim de setembro de 2005, vol.41, n.9, set. 2005.

BANK FOR INTERNATIONAL SETTLEMENTS - BIS. 64th Annual Report. Basel: BIS, 1994.

BANK FOR INTERNATIONAL SETTLEMENTS - BIS. Core principles for systemically important payment systems. Report of the task force on payment system principles and practices. Basel: BIS, 2000.

BARROS, José R. M. de; MANSUETO, Facundo de A. Junior. An analysis of the financial adjustment in Brazil. Secretariat of Economic Policy. Brasília, 1997. Disponível em: $<$ http://www.fazenda.gov.br/ingles/orgaos/ispe/infinan.html >. Acesso em: 18/06/2005. 
BARTHOLOMEW, P.; WHALEN G. Fundamentals of systemic risk. Research in Financial Services: Banking, Financial Markets, and Systemic Risk. Greenwich: JAI Press, v. 7, p.3-18, 1995.

BASEL COMMITTEE ON BANKING SUPERVISION - BCBS. International convergence of capital measurement and capital standards. Basel: BCBS Committee, 1988.

BASEL COMMITTEE ON BANKING SUPERVISION - BCBS. Amendment to the capital accord to incorporate market risks. Basel: BCBS Committee, 1996.

BASEL COMMITTEE ON BANKING SUPERVISION - BCBS. Core principles for effective banking supervision. Basel: BCBS, 1997a.

BASEL COMMITTEE ON BANKING SUPERVISION - BCBS. Principles for the management of interest rate risk. Basel: BCBS, $1997 \mathrm{~b}$.

BASEL COMMITTEE ON BANKING SUPERVISION - BCBS. Principles for the management of credit risk. Basel: BCBS, 2000a.

BASEL COMMITTEE ON BANKING SUPERVISION - BCBS. Sound practices for managing liquidity in banking organisations. Basel: BCBS Committee, 2000b.

BASEL COMMITTEE ON BANKING SUPERVISION - BCBS. Principles for the management and supervision of interest rate risk. Basel: BCBS, 2004.

BERG, Andrew; BORENSZTEIN, Eduardo; PATTILLO, Catherine. Assessing early warning systems: how have they worked in practice? Working Paper.Washington, DC: IMF, 04/52, 2004.

BERG, Andrew; PATTILlO, Catherine. Are currency crises predictable? A test. Staff Papers. Washington, DC: IMF, v. 46, n. 2 , p. 107-138, 1999a.

BERG, Andrew; PATTILLO, Catherine. Predicting currency crises: the indicators approach and an alternative. Journal of International Money and Finance, v. 18, n. 4 , p. 561-586, 1999 b.

BERNSTEIN, Peter L. Desafio dos deuses: a fascinante história do risco. Tradução da 10. edição da obra Against the Gods por Ivo Korytowski. Rio de Janeiro: Campus, 1997.

BESSIS, Joël. Risk management in banking. New York: John Wiley \& Sons, 1998.

BOARD OF GOVERNORS OF THE FEDERAL RESERVE SYSTEM. Supervisory letter SR96-38, de 27/12/1996. Disponível em: <http://www.federalreserve.gov>. Acesso em: 05/07/2005. 
BRUE, Stanley. História do pensamento econômico. Tradução da 6. edição norte-americana por Luciana Penteado Miquelino. São Paulo: Pioneira Thomson Learning, 2005.

BURKART, Oliver; COUDERT, Virginie. Leading indicators of currency crises for emerging countries. Emerging Markets Review, n. 3, p. 107-133, 2002.

BUSSIERE, Matthieu; FRATZSCHER, Marcel. Towards a new early warning system of financial crises. Working Paper. European Central Bank, n. 145, 2002.

CALETTI, E. Bank moral hazard and market discipline. Discussion Paper. London, L. S. E. Financial Markets Group and Political Science, n.326, maio 1999.

CALOMIRIS, Charles W.; KAHN C. M. The role of demandable debt in structuring optimal banking arrangements. American Economic Review, v. 81, n. 3, p. 497-513, 1991.

CAOUETTE, John B.; ALTMAN, Edward I.; NARAYANAN, Paul. Gestão do risco de crédito: o próximo grande desafio financeiro. Rio de Janeiro: Qualitymark, 1999.

CAPELlETTO, Lucio R. Contribuição à avaliação do desempenho operacional de bancos, antes e depois do “Plano Real”. Brasília, 1995. Dissertação (Mestrado) - Programa de Pós-graduação em Administração, Universidade de Brasília - UnB.

CAPRIO Jr., Gerard et al Preventing bank crises: lessons from recent global bank failures. Washington, DC: Economic Development Institute (EDI) - World Bank, 1998.

CAPRIO Jr., Gerard; KLINGEBIEL, Daniela. Episodes of systemic and borderline financial crises. Washington, DC: World Bank, 2003.

CARVALHO, Luiz Nelson G. Pronunciamento de posse como presidente do Conselho Consultivo do IASB em 10/11/2005. Londres, 2005.

CHANG, Roberto; VELASCO, Andres. Financial crises in emerging markets: a canonical model. Working Papers. Cambridge, MA: NBER, n. 6606, 1998.

CHARI, V.; JAGANNATHAN Ravi. Banking panics, information, and rational expectations equilibrium. Journal of Finance, n. 43, p. 749-761, 1988.

CHEN, Yeh-Ning. Banking panics: the role of the first-come, first-served rule and information externalities. Journal of Political Economy, v. 107, n. 5, p. 946-968, 1999.

CORRAR, Luiz. J.; THEOPHILO, Carlos R.; BERGMAN, Daniel R.. Regressões. In: CORRAR, Luiz. J.; THEOPHILO, Carlos R. (Coord.). Pesquisa operacional para decisão em Contabilidade e Administração - Contabilometria. São Paulo: Atlas, 2003. 
CORSETTI, Giancarlo; PESENTI, Paolo A.; ROUBINI, Nouriel. Paper tigers? A model of the Asian crisis. Working Papers. Cambridge, MA: NBER, n. 6783, 1998.

CREDIT SUISSE FIRST BOSTON (CSFB). CreditRisk+: a credit risk management framework. Credit Suisse Financial Products, 1997.

CROUHY, Michel; GALAI, Dan; MARK, Robert. Gerenciamento de risco: abordagem conceitual e prática. Tradução de Carlos Henrique Trieschmann e Luiz Frazão Filho e supervisão de João Carlos Douat. Rio de Janeiro: Qualitymark. São Paulo: SERASA, 2004.

DATZ, Marcelo D. X. da Silveira. Risco sistêmico e regulação bancária no Brasil. Rio de Janeiro, 2002. Dissertação (Mestrado) - Escola de Pós-graduação em Economia da Fundação Getúlio Vargas - EPGE-FGV.

DE BANDT, Olivier. Competition among financial intermediaries and the risk of contagious failures. Notes d.Etudes et de Recherches. Paris: Banque de France, n.30, 1995.

DE BANDT, Olivier; HARTMANN, Phillip. Systemic risk: a survey. Working Paper. Alemanha: European Central Bank, n. 35, 2000.

DEMIRGÜÇ-KUNT, Asli; DETRAGIACHE, Enrica. The determinants of banking crises: evidence from developing and developed countries. Working Papers. Washington, DC: IMF, WP97/106, 1997.

DEMIRGÜÇ-KUNT, Asli; DETRAGIACHE, Enrica. Cross-country empirical studies of systemic bank distress: a survey. Working Paper. Washington, DC: IMF, WP05/96, 2005.

DEUTSCHE BUNDESBANK. The role of economic fundamental in the emergence of currency crises in emerging markets. Deutsche Bundesbank Monthly Report, p. 15-27, abr. 1999. Disponível em: <http://bundesbank.de/download/volkswirtschaft/mba/1999/ 199904mba_art01_ecofunda.pdf>. Acesso em: 19/10/2005.

DIAMOND, Douglas V.; DYBVIG P. Bank runs, deposit insurance, and liquidity. Journal of Political Economy, v. 91, n. 3, p. 401-419, 1983.

DIAMOND, Douglas V.; RAJAN, Raghuram G. Liquidity shortages and banking crises. Working Papers. Cambridge, MA: University of Chicago, NBER, ago. 2003.

DIAS FILHO, José Maria. Gestão tributária na era da responsabilidade fiscal: propostas para otimizar a curva da receita utilizando conceitos de semiótica e regressão logística. São Paulo, 2003. Tese (Doutorado) - Faculdade de Economia, Administração e Contabilidade da Universidade de São Paulo - FEA/USP. 
DOWNING, Douglas; CLARK, Jeffrey. Estatística aplicada. Tradução de Alfredo Alves de Farias. São Paulo: Saraiva, 1998.

EDISON, Hali J. Do indicators of financial crises work? An evaluation of an early warning system. International Finance Discussion Paper. Washington, DC: Board of Governors of the Federal Reserve System, n. 675, 2000.

EICHENGREEN, Barry; ROSE, Andrew K.; WYPLOSZ, Charles. Speculative attacks on peeged exchange rates: an empirical exploration with special reference to the european monetary system. Working Papers. Cambridge, MA: NBER, n. 4898, 1994.

EICHENGREEN, Barry; ROSE, Andrew K.; WYPLOSZ, Charles. Contagious currency crises. Working Papers. Cambridge, MA: NBER, n. 5681, 1996.

ESPAHBODI. Pouran. Identification of problem banks and binary choice models. Journal of Banking and Finance, n. 15, p. 53-71, 1991.

EVANS, Owen et al. Macroprudential indicators of financial system soundness. IMF Occasional Paper. Washington DC: IMF, n. 192, 2000.

FISHER, Irwing. The purchasing power of money. New York: Macmillan, p. 154-157, 1911.

FLOOD, Robert; GARBER, Peter. A systemic banking collapse in a perfect foresight world. Working Papers. Cambridge, MA: NBER, n. 691, 1981.

FLOOD, Robert; GARBER, Peter. Collapsing exchange rate regimes: some linear examples. Journal of International Economics, v. 17, p. 1-13, 1984.

FLOOD, Robert; MARION, Nancy. Perspectives on the recent currency crisis literature. Working Paper. Washington, DC: IMF, WP98/130, 1998.

FONTAINE, Thomson. Currency crises in developed and emerging market economies: a comparative empirical treatment. Working Paper. Washington, DC: IMF, WP05/13, 2005.

FRANKEL, Jeffrey; ROSE, Andrew K. Currency crashes in emerging markets: empirical indicators. Working Paper. Cambridge, MA, NBER, n. 5437, 1996.

FREIXAS, Xavier; PARIGI, Bruno; ROCHET, Jean-Charles. Systemic risk, interbank relations and liquidity provisions by yhe central bank. Journal of Money, Credit, and Banking, v. 32, n. 3, p. 1-37, 1999.

FURFINE, Craig H. Interbank exposures: quantifying the risk of contagion. BIS Working Papers. Basel, Switzerland: BIS, n. 70, 1999. 
GARBER, Peter M.; LUMSDAINE, Robin L; VAN DER LEIJ, Marco. Deutsche Bank alarm clock: forecasting exchange rate and interest rate events in emerging markets. New York: Deutsche Bank, 2000.

GOLDSTEIN, Morris; KAMINSKY, Graciela L.; REINHART Carmen M.. Assessing financial vulnerability: an early warning system for emerging markets. Washington, DC: Institute for International Economics, 2000.

GONZÁLEZ-HERMOSILLO, Brenda. Determinants of ex-ante banking system distress: a macro-micro empirical exploration. Working Papers Series. Washington, DC: IMF WP99/33, 1999.

GORTON, Gary. Banking panics and business cycles. Oxford Economic Papers, n. 40, p.751-781, 1988.

GREUNING, Hennie van; BRATANOVIC, Sonja B. Analyzing banking risk: a framework for assessing corporate governance and financial risk management. Washington, DC: World Bank, 1999.

GRUBEN, William C.; WELCH, John H. Banking and currency crisis recovery: Brazil's turnaround of 1999. Dallas: Federal Reserve Bank of Dallas, 2001.

GUJARATI, Damodar N. Econometria básica. 3. ed. São Paulo: Makron Books, 2000.

HAIR Jr., Joseph et al. Multivariate data analysis. 5. ed. New Jersey: Prentice Hall, 1998.

HENDRIKSEN, Eldon S.; VAN BREDA, Michael F. Teoria da contabilidade. Tradução da 5. ed. americana por Antonio Zoratto Sanvicente. São Paulo: Atlas, 1999.

HONOHAN, Patrick; e KLINGEBIEL, Daniela. Controlling fiscal costs of banking crises. In: KLINGEBIEL, Daniela; e LAEVEN, Luc. Managing the real and fiscal effects of banking crises. World Bank Discussion Paper. Washington, DC: World Bank, WDP428, p.15-29, 2002 .

HOSMER, David W.; LEMESHOW, Stanley. Applied logistic regression. New York: John Wiley \& Sons, 1989.

HUANG, Haizhou; XU, Chenggang. Financial institutions, financial contagion, and financial crises. Working Paper. Washington, DC: IMF, WP00/92, 2000.

INTERNATIONAL MONETARY FUND - IMF. Guide to the data dissemination standards. Module 1: the special data dissemination standard. Washington DC: IMF, 1996. 
INTERNATIONAL MONETARY FUND - IMF. World economic outlook. Washington DC: IMF, 1998a.

INTERNATIONAL MONETARY FUND - IMF. International capital markets. Washington DC: IMF, 1998b.

INTERNATIONAL MONETARY FUND - IMF. Macroprudential analysis: selected aspects. Background paper. Monetary and Exchange Affairs Department. Washington, DC: IMF, 2001a.

INTERNATIONAL MONETARY FUND - IMF. Assessing the determinants and prospects for the pace of market access by countries emerging from crises - country cases. Policy Development and Review Department. Washington DC: IMF, 2001b.

INTERNATIONAL MONETARY FUND - IMF. International financial statistics. Washington DC: IMF, 2003. CD-ROM.

INTERNATIONAL MONETARY FUND - IMF. Debt-related vulnerabilities and financial crises: an application of the balance sheet approach to emerging market countries. The Policy Development and Review Department. Washington DC: IMF, 2004a.

INTERNATIONAL MONETARY FUND - IMF. Compilation guide on financial soundness indicator. Chapter 6. Washington DC: IMF, $2004 \mathrm{~b}$.

INTERNATIONAL MONETARY FUND; WORLD BANK. Financial sector assessment: $a$ handbook. Chapter 3: assessing financial stability. Washington DC: IMF e World Bank, 2005.

IUDICÍBUS, Sérgio de. Teoria da contabilidade. São Paulo: Atlas, 1981.

IUDICÍBUS, Sérgio de et al. Contabilidade introdutória. 9. ed. São Paulo: Atlas, 1998.

JACKLIN, C.; BHATTACHARYA Sudipto. Distinguishing panics and information-based runs: welfare and policy implications. Journal of Political Economy, v. 96, n. 3, p. 568-592, 1988.

JANOT, Márcio M. Previsão de insolvência bancária no Brasil: aplicação de diferentes modelos entre 1995 e 1998. Rio de Janeiro, 1999. Dissertação (Mestrado) - Pontifícia Universidade Católica do Rio de Janeiro - PUC/RJ.

JORION, Philippe. Value at risk: a nova fonte de referência para a gestão do risco financeiro. Tradução da edição norte-americana de Thierry Barbe. 2. ed. São Paulo: Bolsa de Mercadorias e Futuros, 2003. 
KAMIN, Steven B.; SCHINDLER, John W.; SAMUEL, Shawna L. The contribution of domestic and external factors to emerging market devaluation crises: an early warning systems approach. International Finance Discussion Paper. Washington, DC: Board of Governors of the Federal Reserve System, n. 711, 2001.

KAMINSKY, Graciela. Currency and banking crises: the early warnings of distress. Working Paper. Washington, DC: IMF, WP99/178, 1999.

KAMINSKY, Graciela; LIZONDO, Saul; REINHART, Carmem M. Leading indicators of currency crises. Staff Paper. Washington, DC: IMF, v.45, n. 1, 1998.

KAMINSKY, Graciela; REINHART Carmen M. Financial crises in Asia: then and now. American Economic Review, v. 88, n. 2, p. 444-448, 1998.

KAMINSKY, Graciela; REINHART Carmen M. The twin crises: the causes of banking and balance-of-payments problems. American Economic Review, v. 89, n. 3, p. 473-500, 1999.

KANITZ, Stephen C. Como prever falências de empresas. Revista Exame, p.95-102, dezembro 1974.

KAUFMAN, George G. Comment on systemic risk. In: Research in financial services: banking, financial markets, and systemic risk. Greenwich: JAI Press, v. 7, p. 47-52, 1995.

KASSAI, Sílvia. Utilização da análise por envoltória de dados (DEA) na análise de demonstrações contábeis. São Paulo, 2002. Tese (Doutorado) - Faculdade de Economia, Administração e Contabilidade da Universidade de São Paulo - FEA/USP.

KEALHOFER, Stephen; BONH, Jeffrey R. Portfolio management default risk. San Francisco, CA, USA: KMV LLC, 2001.

KELINGER, Fred N. Metodologia de pesquisa em ciências sociais: um tratamento conceitual. São Paulo: EPU, 1980, p.244.

KEYNES, John M. A teoria geral do emprego, do juro e da moeda. Tradução de Mário R. da Cruz. São Paulo: Nova Cultural, 1988.

KINDLEBERGER, Charles. Manias, panics, and crashes. New York: Basic Books, 1978.

KRUGMAN, Paul. A model of balance of payment crises. Journal of Money, Credit, and Banking, v. 11, p. 311-325, 1979.

LEHAR, Alfred. Measuring systemic risk: a risk management approach. Austria: University of Vienna Press, 2003. 
LEVY-YEYATI, Eduardo; PERIA, Maria Soledad M.; SCHMUKLER, Sérgio L. Market discipline under systemic risk: evidence from bank runs in emerging economies. Journal of Financial Intermediation. Washington, DC: World Bank, 2004.

LINDGREN, Carl-Johan; GARCIA Gillian; SAAL, Matthew I. Bank soundness and macroeconomic policy. Washington, DC: IMF, 1996.

LINDGREN, Carl-Johan et al. Financial sector crisis and restructuring: lessons from Asia. Occasional Paper. Washington, DC: IMF, n. 188, 1999.

LUNDBERG, Eduardo. Rede de proteção e saneamento do sistema bancário. In: SADDI, Jairo (Org.). Intervenção e liquidação no sistema financeiro nacional. São Paulo: Texto Novo, 1999.

MAIA, Geraldo. Restructuring the banking system - the case of Brazil. In: Bank restructuring in practice. BIS Policy Papers. Basel, Switzerland: BIS, n. 6, p. 106-123, agosto 1999.

MAIA, Geraldo. Reestruturação Bancária no Brasil: o Caso do PROER. Notas técnicas do Banco Central do Brasil. Brasília-DF: Banco Central do Brasil, n. 38, 2003.

MALHOTRA, Naresh K. Pesquisa de marketing: uma orientação aplicada. 3. ed. Porto Alegre: Bookman, 2001.

MANSO, Fabiano dos Santos. Uma breve análise do comércio exterior venezuelano a partir da década de 1990. Relatório anual feito ao Instituto de Economia da Universidade Federal de Uberlândia, 2005.

MARINS, André. Mercados derivativos e análise de risco. Rio de Janeiro: AMS, v. 1, 2004.

MÁRIO, Poueri C. Contribuição ao estudo da solvência empresarial: uma análise dos modelos de previsão - estudo exploratório aplicado em empresas mineiras. São Paulo, 2002. Dissertação (Mestrado) - Faculdade de Economia, Administração e Contabilidade da Universidade de São Paulo - FEA/USP.

MARKOWITZ, Harry. Portfolio selection. Journal of Finance, v. 7, n. 1, março 1952.

MAROCO, João. Análise estatística: com utilização do SPSS. Lisboa: Sílaba, 2003.

MARQUES, Newton F. da Silva. Estrutura e funções do sistema financeiro no Brasil. Brasília: Thesaurus, 2003.

MARTIN, Daniel. Early warning of banking failure: a logit regression approach. Journal of Banking and Finance, v. 1, p. 249-276, 1977. 
MARTINEZ, Guillermo Ortiz. What lessons does the mexican crisis hold for recovery in Asia? Finance and Development, v. 35, n. 2, junho 1998.

MARTINS, Eliseu; ASSAF NETO, Alexandre. Administração financeira: as finanças das empresas sob condições inflacionárias. São Paulo: Atlas, 1986.

MARTINS, Gilberto de A. Manual para elaboração de monografias e dissertações. 3. ed. São Paulo: Atlas, 2002.

MATIAS, Alberto B. Insucesso de grandes bancos privados brasileiros de varejo. Tese de Livre Docência. Faculdade de Economia, Administração e Contabilidade da Universidade de São Paulo - FEA/USP, São Paulo, 1999.

MATIAS, Alberto B.; SIQUEIRA, José O. Risco bancário: modelo de previsão de insolvência de bancos no Brasil. Revista de Administração - USP. São Paulo, p. 19-28, abril-junho 1996.

MATOS, Orlando C. Econometria básica: teoria e aplicações. $3^{\text {a }}$. edição. São Paulo: Atlas, 2000 .

MEYER, Paul A.; PIFER, Howard W. Prediction of bank failures. Journal of Finance, p. 853-868, setembro 1970.

MILESI-FERRETI, Gian M.; RAZIN, Assaf. Current account reversals and currency crises: empirical regularities. Working Paper. Washington, DC: IMF, WP98/89, 1998.

MISHKIN, Frederick S. Understanding financial crises: a developing country perspective. Working Papers Series. Cambridge, MA: NBER, n. 5600, 1996.

MORGAN, J. P. RiskMetrics. Technical document, New York: J.P. Morgan \& Co. Incorporated, 1995.

MORGAN, J. P. CreditMetrics. Technical document, New York: J.P. Morgan \& Co. Incorporated, 1997.

OBSTFELD, Maurice. Rational and self-fulfilling balance payment crises. Working Paper Series. Cambridge, MA: NBER, n. 1486, 1984.

OLIVEIRA, Paula C. S. de. Avaliação do acompanhamento dos riscos de mercado e de liquidez pelas entidades supervisoras bancárias. Brasília, 2005. Dissertação (Mestrado) Programa de Pós-Graduação em Economia, Departamento de Economia, Universidade de Brasília - UnB. 
OLIVEIRA, Roberta B. S.; BARROSO, Lucia P. Detecção de problemas em instituições financeiras utilizando modelos estatísticos. In: SEMANA DE CONTABILIDADE DO BANCO CENTRAL DO BRASIL, 9, 2000, São Paulo. Anais... Semana de Contabilidade do Banco Central do Brasil, 2000.

ORGANIZATION FOR ECONOMIC CO-OPERATION AND DEVELOPMENT - OECD. Bank profitability: Financial statements of banks. Edição 1999. Paris, França: OECD, 1999.

ORGANIZATION FOR ECONOMIC CO-OPERATION AND DEVELOPMENT - OECD. Bank profitability: Financial statements of banks. Edição 2002. Paris, França: OECD, 2002.

OZKAN, Gulcin F.; SUTHERLAND, Alan. Policy measures to avoid a currency crisis. Journal of the Royal Economic Society, v. 105, p. 510-19, março 1995.

PAULA, J. B. Relações financeiras e flutuações na atividade econômica: uma abordagem em Keynes, Minsky e Stiglitz. Curitiba, 2003. Dissertação (Mestrado em Desenvolvimento Econômico) - Ciências Sociais Aplicadas, Universidade Federal do Paraná.

PEREIRA, Ana Paula M.; SEABRA, Fernando. Crises cambiais e bancárias na década de 1990: uma análise de painel aplicada a mercados emergentes. In: ENCONTRO NACIONAL DE ECONOMIA, XXXII, João Pessoa. 2004. Anais... ANPEC - Associação Nacional dos Centros de Pós-Graduação em Economia, n. 33, 2004.

PEREIRA, Júlio César R. Análise de dados qualitativos: estratégias metodológicas para as ciências da saúde, humanas e sociais. 3. ed. São Paulo: EDUSP, 2001.

ROCHET, Jean C.; TIROLE, Jean. Controlling risk in payment systems. Journal of Money, Credit and Banking, v. 28, n. 4, Chapter 2: Payment Systems Research and Public Policy Risk, Efficiency, and Innovation, p.832-862, 1996.

ROSS, Stephen A.; WESTERFIELD, Randolph W.; JAFFE, Jeffrey F. Administração financeira: corporate finance. Tradução de Antonio Zoratto Sanvicente. São Paulo: Atlas, 1995.

ROSSETTI, José Paschoal. Introdução à economia. 9ª edição. São Paulo: Atlas, 1982.

ROY, Amlan; TUDELA, Maria M. Emerging market risk indicator (Emri): re-estimated Sept 00. New York: Credit Suisse First Boston (CSFB), 2001.

SACHS, Jeffrey D. et al. Financial crises in emerging markets: the lessons from 1995. Brookings Papers on Economic Activity, v. 1996, n. 1, p. 147-215, 1996. 
SANTOMERO, Anthony M.; VINSO, Joseph D. Estimating the probability of failure for commercial banks and the banking system. Journal of Banking and Finance, v. 1, p.185205, 1977.

SAUNDERS, Anthony. Administração de instituições financeiras. Tradução da 2. ed. norte-americana por Antonio Zoratto Sanvicente. São Paulo: Atlas, 2000.

SECURATO, José Roberto. Decisões financeiras em condições de risco. São Paulo: Atlas, 1996.

SECURATO, José Roberto; PEROBELLI, Fernanda F.C. Introdução ao estudo da avaliação do risco da empresa. In: DUARTE, Antonio M.; VARGA, Gyorgy. Gestão de riscos no Brasil. Rio de Janeiro: Financial Consultoria, 2003, p. 711.

SOUZA, Enio B. M. de; ARAGÃO, César. Uma proposta de uso de modelos de simulação para alocação de capital em bancos de atacado. In: DUARTE, Antonio M.; VARGA, Gyorgy. Gestão de riscos no Brasil. Rio de Janeiro: Financial Consultoria, 2003, p.397.

SPSS Inc. SPSS regression models 12.0. In: Manual SPSS 12.0. EUA: SPSS Inc., 2003. Disponível em: <http://www.sc.uevora.pt/pdf/manual_spss_12/spss_regression_models_12>. Acesso em: 11/10/2005.

TABAK, Benjamin M.; STAUB, Roberta B. Estimating the probability of failure for financial institutions: the case of Brazil. Working Paper Series, Banco Central do Brasil, n. 54, novembro 2002.

VALECILLOS, Hector T.; RODRIGUEZ, Omar Bello. La investigación económica en la Venezuela de los 90. In: La economía contemporánea de Venezuela 1990-1999. Ensaios escolhidos, capítulo I, Banco Central da Venezuela, Caracas, Venezuela, 2001.

VERCELLI, A. Financial fragility and cyclical fluctuations. Quaderni di Dipartimento di economia Politica di Università degli Studi di Siena, n. 253, 1999. Disponível em: $<$ http://www.econ-pol.unisi.it/ab_quaderni/ab253.html>. Acesso em: 11/10/2005.

WILSON, Thomas C. Measuring and managing credit portfolio risk: part I - modelling systemic default risk. Risk Magazine, n. 10, sep. 1997a.

WILSON, Thomas C. Measuring and managing credit portfolio risk: part II - portfolio loss distribuitions. Risk Magazine, n. 10, oct. 1997b.

WORREL, DeLisle. Quantitative assessment of the financial sector: an intergrated approach. Working Paper. Washington, DC: IMF, WP04/153, 2004. 


\section{APÊNDICES}

APÊNDICE 1: RELAÇÃO DE FONTES DAS VARIÁVEIS ECONÔMICAS E CONTÁBEIS

APÊNDICE 2: PLANILHAS COM AS VARIÁVEIS CONTÁBEIS E ECONÔMICAS APÊNDICE 3: INDICADORES SUBMETIDOS AOS TESTES ESTATÍSTICOS

APÊNDICE 4: CÁLCULO DA VARIAÇÃO NO INDICADOR DCAOC

APÊNDICE 5: CÁLCULO DO PONTO DE CORTE DAS EQUAÇÕES

APÊNDICE 6: CÁLCULO DOS ÍNDICES DE RISCO SISTÊMICO (IRS) POR PAÍS 


\section{APÊNDICE 1: RELAÇÃO DE FONTES DAS VARIÁVEIS ECONÔMICAS E CONTÁBEIS}

\section{Econômicas}

a) Taxa de juros: International Financial Statistics (IMF, 2003), country tables, economic concept view, deposit monetary banks, interest rates, money market rate, código 19360BZF.

b) Taxa de câmbio: International Financial Statistics (IMF, 2003), country tables, economic concept view, country exchange rates, national currency per SDR, market rate, código 193AAZF. Utilizou-se a paridade da moeda local com o SDR ${ }^{68}$.

c) Reservas internacionais: International Financial Statistics (IMF, 2003), country tables, economic concept view, international liquidity, monetary authorities - reserves, total reserves - millions of SDR, international reserves, código 1931SZF.

d) Produto interno bruto (PIB): International Financial Statistics (IMF, 2003), country tables, economic concept view, national accounts, gross domestic product (GDP), código 12299BZF.

\section{Contábeis}

\subsection{Países com experiência de crise}

a) Patrimônio líquido: International Financial Statistics (IMF, 2003), country tables, economic concept view, financial sector, capital accounts, código 12227AZF.

b) Depósitos: International Financial Statistics (IMF, 2003), country tables, economic concept view, financial sector, demand deposits, código 12224ZF, e time and savings deposits, código 12225ZF.

c) Ativos em moeda estrangeira: International Financial Statistics (IMF, 2003), country tables, economic concept view, financial sector, foreign assets, código 12221ZF.

d) Passivos em moeda estrangeira: International Financial Statistics (IMF, 2003), country tables, economic concept view, financial sector, foreign liabilities, código 12226CZF.

e) Ativo total: demonstrações contábeis do sistema bancário, obtidos nos sítios ou em planilhas enviadas pelos supervisores bancários de cada país. Os sítios estão expostos na planilha de dados individuais.

f) Ativos líquidos: demonstrações contábeis do sistema bancário, obtidos nos sítios ou em planilhas enviadas pelos supervisores bancários de cada país. Os sítios estão expostos na planilha de dados individuais.

g) Operações de crédito e créditos anormais: demonstrações contábeis do sistema bancário, obtidos nos sítios ou em planilhas enviadas pelos supervisores bancários de cada país. Os sítios estão expostos na planilha de dados individuais.

\subsection{Países sem experiência de crise}

Todos os dados contábeis são de países membros da OECD e foram extraídos dos relatórios Bank Profitability, de 1999 e 2002, editado pela OECD. Os dados desses relatórios são anuais e compreendem os períodos entre 1998 e 2001.

68.SDR (Special Drawing Rights) é um ativo internacional que serve de unidade de medida para o IMF. O valor é calculado com base numa cesta de moedas formada pelo Euro, Yen japonês, Libra esterlina e Dólar americano. 


\section{APÊNDICE 2: PLANILHAS COM AS VARIÁVEIS CONTÁBEIS E ECONÔMICAS}

\section{PAÍS COM EXPERIÊNCIA DE CRISE}

\begin{tabular}{|c|c|c|c|c|c|c|c|c|}
\hline \multicolumn{5}{|c|}{ 1. Argentina - mar/1995 } & \multicolumn{4}{|c|}{ Em milhões de pesos argentinos } \\
\hline Variáveis & TRIM-8 & TRIM-7 & TRIM-6 & TRIM-5 & TRIM-4 & TRIM-3 & TRIM-2 & TRIM-1 \\
\hline atrimônio Líquido & 11294814 & 11309266 & 11860812 & 12503323 & 12528782 & 12702085 & 13240995 & 13518971 \\
\hline tal & 59891259 & 61401826 & 66355714 & 69607390 & 83546807 & 88241821 & 5926 & 88030975 \\
\hline issivo & 48596445 & 50092560 & 54494902 & 57104067 & 71018025 & 75539736 & 774 & 2004 \\
\hline tivos Líquidos & 4168498 & 4461349 & 5398961 & 5488338 & 6749853 & 6398150 & 5874350 & 5307 \\
\hline Créd. & 50515628 & 50407574 & 53119447 & 55766047 & 58578536 & 61049183 & 63401436 & 62966659 \\
\hline ormais & 0 & 0,1587 & 0,1624 & 0,16000 & 0,1570 & 0,1675 & 0,1720 & 0,1800 \\
\hline epós & 27395000 & 30223000 & 33394000 & 35386000 & 38782990 & 40025500 & 423 & \\
\hline $\mathrm{xpc}$ & -5655000 & -3563000 & -2974000 & -3894000 & -4483860 & -5188900 & -57 & 940 \\
\hline B & 212627000 & 241255000 & 243494000 & 248644000 & 235083000 & 263684000 & 2608 & 23000 \\
\hline axa & 7 & 5,553 & 6,523 & 6,000 & 5,043 & 297 & 00 & 9,680 \\
\hline & 1 & & & & 1,000 & & & \\
\hline $\mathrm{rar}$ & 0 & & 00 & & 0,000 & 000 & & 000 \\
\hline $2 \mathrm{~s}$ & 7668 & & & 94 & 9517 & 9299 & 59 & 967 \\
\hline Jar & 0 & $-0,056$ & 57 & & $-0,066$ & 0,023 & 26 & 0,100 \\
\hline$\sqrt{2}$ & 0 & 0,056 & $-0,157$ & $-0,217$ & 0,066 & 0,023 & 26 & $-0,100$ \\
\hline réd & 37639458 & 38866005 & 40079870 & 42599879 & 44991771 & 3072 & 008 & 2011 \\
\hline o & 12876170 & 11541569 & 13039577 & 13166168 & 13586765 & 6111 & 2428 & 4648 \\
\hline ep & 4324000 & 4523000 & 4636000 & 5052000 & 5193290 & 2800 & 8260 & 5133120 \\
\hline ep & 23071000 & 25700000 & 28758000 & 30334000 & 33589700 & 34492700 & 37134700 & 37109200 \\
\hline Lucre & & & & 44023 & 33199 & 271503 & 630 & 9626 \\
\hline & 4462000 & 4715000 & 5845000 & 5148000 & 5221770 & 300 & 990 & 5586760 \\
\hline & 10117000 & 8278000 & 8819000 & 2000 & 9705630 & 106 & 500 & 4700 \\
\hline & 55429259 & 56686826 & 60510714 & 64459390 & 78325037 & 828 & 5936 & 82444215 \\
\hline & 38479445 & 41814560 & 45675902 & 48062067 & 61312395 & & & 63517304 \\
\hline & 16949814 & 14872266 & 14834812 & 16397323 & 17012642 & 17890985 & 18987505 & 18926911 \\
\hline ssist & 2376300 & 2414100 & 2431500 & 2233600 & 2351050 & 2302640 & 2240280 & 2184450 \\
\hline Adica & & & & & & & & \\
\hline ROE & & & & & 1,0020 & & & 1,0210 \\
\hline TPL & & & & & 6,6684 & 9470 & 19 & 6,5117 \\
\hline LD & & & & & 0,1134 & 1023 & 0,0857 & 0,0938 \\
\hline $\mathrm{AC}$ & & & & & 0,1570 & 0,1675 & 0,1720 & 0,1800 \\
\hline TOPPL & & & & & $-0,3579$ & $-0,4085$ & $-0,4340$ & $-0,4000$ \\
\hline & & & & & & & & \\
\hline$F$ & & & & & $-0,5455$ & & & $-1,6196$ \\
\hline $\mathrm{RJ}($ & & & & & 2,0696 & 738 & 4,2357 & 5,6684 \\
\hline & & & & & 0,0420 & 0,0666 & 0,0927 & 0,1092 \\
\hline & & & & & 1,6462 & 1,5025 & 1,6195 & 0,8941 \\
\hline IRATPIB & & & & & 0,4369 & 0,4158 & 0,4207 & 0,3482 \\
\hline
\end{tabular}

Fontes: http://www.bcra.gov.ar/pdfs/estadistica/balser.xls; IMF (2003). 


\section{PAÍS COM EXPERIÊNCIA DE CRISE}

2. Argentina - dez/2001

Variáveis

Patrimônio Líquido
Ativo Total

Passivo

Ativos Líquidos

Oper. de Crédito

Créditos Anormais

Depósitos Totais

Expos. Câmbio

PIB (em mil)

Taxa de Juros

Taxa de Câmbio

Variação Câmbio

Reservas Intern.

Variação Reservas

INDPRESCAM

crédito privado

crédito público

depósitos vista

depósitos prazo

Lucro-prejuízo

Ativo em FX

Passivo em FX

Ativo em TJ

Passivo em TJ

Expos. Taxa Juros

Assist. Financ. BC

Indicador Contábil

ROE

ATPL

ALDT

CAOC

NOPPL

Indicador de Riscos

$\operatorname{IRFX}(4,99 \%)$

$\operatorname{IRTJ}(4,99 \%)$

$\operatorname{IRCRE}(4,99 \%)$

IRDTAL

IRATPIB

Fontes: http://www.bcra.gov.ar/pdfs/estadistica/balser.xls; IMF (2003).
Em bilhões de pesos argentinos

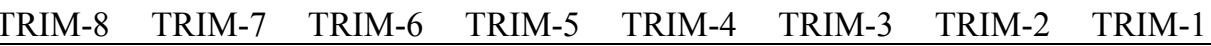

$\begin{array}{rrrrrrrr}16437 & 15428 & 15449 & 15682 & 16726 & 16673 & 16412 & 16588 \\ 154744 & 161941 & 170278 & 172529 & 165154 & 165341 & 153398 & 139253 \\ 138307 & 146514 & 154828 & 156846 & 148428 & 148668 & 136986 & 122664 \\ 3742 & 3013 & 3112 & 2939 & 3198 & 3012 & 2889 & 2850 \\ 96614 & 95847 & 93801 & 94817 & 94564 & 90987 & 90989 & 87559 \\ 0 & 0,1659 & 0,1696 & 0,16702 & 0,1670 & 0,1459 & 0,1495 & 0,1748 \\ 75414 & 77778 & 79743 & 80049 & 77944 & 76929 & 77401 & 70882 \\ -7823 & -5765 & -3581 & -4827 & -6260 & -5476 & -6588 & -6883 \\ 289427 & 270444 & 291796 & 287496 & 287079 & 263331 & 288026 & 271367 \\ 9 & 7,033 & 6,973 & 7,467 & 11,107 & 11,917 & 10,563 & 26,696 \\ 1 & 1,000 & 1,000 & 1,000 & 1,000 & 1,000 & 1,000 & 1,000 \\ & 0,000 & 0,000 & 0,000 & 0,000 & 0,000 & 0,000 & 0,000 \\ 19139 & 18257 & 19214 & 19161 & 19301 & 17388 & 16921 & 15947 \\ & -0,046 & 0,052 & -0,003 & 0,007 & -0,099 & -0,027 & -0,058 \\ 68431 & 66937 & 65969 & 65655 & 65842 & 61583 & 60866 & 57425 \\ 28182 & 28909 & 27831 & 29160 & 28722 & 29403 & 30122 & 30133 \\ 8099 & 7868 & 8100 & 7442 & 7267 & 6429 & 7038 & 5959 \\ 67314 & 69910 & 71643 & 72607 & 70677 & 705005 & 70362 & 64923 \\ & & 73722 & 185766 & 147391 & 150637 & 315413 & 92807 \\ 15007 & 15507 & 18389 & 19348 & 17911 & 19305 & 16122 & 12874 \\ 22831 & 21273 & 21970 & 24175 & 24170 & 24781 & 22709 & 19757 \\ 139736 & 146433 & 151888 & 153181 & 147243 & 146036 & 137276 & 126379 \\ 115476 & 125240 & 132858 & 132671 & 124257 & 123886 & 114276 & 102907 \\ 24259 & 21192 & 19029 & 20509 & 22985 & 22149 & 23000 & 23471 \\ 307 & 293 & 213 & 99 & 78 & 40 & 37 & 148\end{array}$

$\begin{array}{rrrr}0,0088 & 0,0090 & 0,0192 & 0,0056 \\ 9,8740 & 9,9166 & 9,3463 & 8,3945 \\ 0,0400 & 0,0386 & 0,0368 & 0,0381 \\ 0,1670 & 0,1459 & 0,1495 & 0,1748 \\ -0,3742 & -0,3284 & -0,4014 & -0,4149 \\ & & & \\ -1,5022 & -1,6306 & -1,5542 & -6,4967 \\ 5,5164 & 6,5953 & 5,4263 & 22,1532 \\ 0,0180 & 0,1220 & 0,1257 & 0,1475 \\ 0,7653 & 1,0080 & 0,9735 & 2,4632 \\ 0,6091 & 0,6560 & 0,5881 & 0,6050\end{array}$




\section{PAÍS COM EXPERIÊNCIA DE CRISE}

3. Brasil - dez/1995

Em milhões de reais

Variáveis TRIM-

\begin{tabular}{|c|c|c|c|c|c|c|c|c|}
\hline Patrimônio Líquido & 24587 & 25948 & 27418 & 28368 & 29840 & 31559 & 34276 & 33787 \\
\hline Ativo Total & 288910 & 310543 & 319889 & 363590 & 400006 & 412863 & 454158 & 491101 \\
\hline Passivo & 264323 & 284595 & 292472 & 335222 & 370166 & 381303 & 419882 & 457315 \\
\hline Ativos Líquidos & 80938 & 80163 & 99591 & 106659 & 127349 & 128281 & 165826 & 158317 \\
\hline Oper. de Créd. & 105028 & 117051 & 131664 & 143446 & 150920 & 154188 & 165239 & 169125 \\
\hline Créditos Anormais & 0,2172 & 0,2640 & 0,06698 & 0,0839 & 0,0900 & 0,1074 & 0,1066 & 0,1191 \\
\hline Depósitos Totais & 97884 & 106091 & 124284 & 138696 & 143371 & 159443 & 175253 & 176553 \\
\hline Expos. Câmbio & -9271 & -6750 & -3610 & -6754 & -7200 & -9968 & -10050 & -9942 \\
\hline PIB & 66458 & 128495 & 135368 & 143064 & 155013 & 166059 & 182056 & 170262 \\
\hline Taxa de Juros & 11381,0 & 80,740 & 57,020 & 53,530 & 63,530 & 55,210 & 41,210 & 32,680 \\
\hline Taxa de Câmbio & 1,450 & 1,250 & 1,240 & 1,400 & 1,450 & 1,440 & 1,450 & 1,440 \\
\hline Variação Câmbio & 2,085 & $-0,138$ & $-0,008$ & 0,129 & 0,036 & $-0,007$ & 0,007 & $-0,007$ \\
\hline \multicolumn{9}{|l|}{ Reservas Intern. } \\
\hline \multicolumn{9}{|l|}{ Variação Reservas } \\
\hline \multicolumn{9}{|l|}{ INDPRESCAM } \\
\hline crédito privado & 103041 & 155515 & 175533 & 194471 & 201482 & 203461 & 211258 & 223133 \\
\hline crédito público & 33692 & 38519 & 45577 & 53203 & 49229 & 46733 & 56351 & 77956 \\
\hline depósitos vista & 5363 & 10257 & 13979 & 10374 & 9314 & 9604 & 14034 & 13001 \\
\hline depósitos prazo & 93742 & 105595 & 119979 & 141540 & 137508 & 154998 & 159901 & 169837 \\
\hline Lucro-prejuízo & 10 & 35 & 243 & 43 & 446 & -866 & -791 & -524 \\
\hline Ativo em FX & 16919 & 15853 & 17602 & 18908 & 18374 & 17222 & 18159 & 19764 \\
\hline Passivo em FX & 26190 & 22603 & 21212 & 25662 & 25574 & 27190 & 28209 & 29706 \\
\hline Ativo em TJ & 271991 & 294690 & 302287 & 344682 & 381632 & 395641 & 435999 & 471337 \\
\hline Passivo em TJ & 238133 & 261992 & 271260 & 309560 & 344592 & 354113 & 391673 & 427609 \\
\hline Expos. Taxa Juros & 33858 & 32698 & 31028 & 35122 & 37040 & 41527 & 44326 & 43729 \\
\hline Assist. Financ. BC & 24891 & 38865 & 50749 & 54428 & 45344 & 43464 & 47584 & 75024 \\
\hline \multicolumn{9}{|l|}{ Indicador Contábil } \\
\hline ROE & & & & 0,0015 & 0,0149 & $-0,0274$ & $-0,0231$ & $-0,0155$ \\
\hline ATPL & & & & 12,8171 & 13,4048 & 13,0821 & 13,2501 & 14,5354 \\
\hline ALDT & & & & 0,3766 & 0,5720 & 0,5320 & 0,6747 & 0,4718 \\
\hline CAOC & & & & 0,0839 & 0,0900 & 0,1074 & 0,1066 & 0,1191 \\
\hline NOPPL & & & & $-0,2381$ & $-0,2413$ & $-0,3159$ & $-0,2932$ & $-0,2943$ \\
\hline \multicolumn{9}{|l|}{ Indicador de Riscos } \\
\hline $\operatorname{IRFX}(4,99 \%)$ & & & & $-6,6510$ & $-5,8374$ & $-2,7776$ & $-5,4557$ & $-8,2203$ \\
\hline $\operatorname{IRTJ}(4,99 \%)$ & & & & 34,5857 & 30,0303 & 11,5717 & 24,0624 & 36,1558 \\
\hline $\operatorname{IRCRE}(4,99 \%)$ & & & & 0,9947 & 0,9425 & 0,1647 & 0,1153 & 0,1206 \\
\hline IRDTAL & & & & 0,7081 & 0,4128 & 0,3447 & 0,2836 & 0,3779 \\
\hline IRATPIB & & & & 2,9840 & 3,1193 & 2,9933 & 2,9088 & 3,3753 \\
\hline
\end{tabular}

Fontes: http://www.bcb.gov.br/fis/top50; IMF (2003). 


\section{PAIIS COM EXPERIÊNCIA DE CRISE}

4. Brasil - dez/1999

Em milhões de reais

\begin{tabular}{|c|c|c|c|c|c|c|c|c|}
\hline Variáveis & TRIM-8 & TRIM-7 & TRIM-6 & TRIM-5 & TRIM-4 & TRIM-3 & TRIM-2 & TRIM-1 \\
\hline Patrimônio Líquido & 36555 & 36692 & 39813 & 40190 & 35684 & 37000 & 35857 & 44886 \\
\hline Ativo Total & 598929 & 647033 & 665320 & 655108 & 660901 & 677289 & 653558 & 647569 \\
\hline Passivo & 562374 & 610341 & 625507 & 614918 & 625216 & 640290 & 617701 & 602683 \\
\hline Ativos Líquidos & 201140 & 226728 & 235184 & 279340 & 246400 & 257702 & 233708 & 261465 \\
\hline Oper. de Créd. & 191968 & 199963 & 210145 & 177859 & 177031 & 176195 & 180429 & 179494 \\
\hline Créditos Anormais & 0 & 0,2301 & 0,2847 & 0,34976 & 0,4638 & 0,5955 & 0,4257 & 0,5704 \\
\hline Depósitos Totais & 194210 & 203021 & 214203 & 233297 & 238787 & 247046 & 246388 & 249576 \\
\hline Expos. Câmbio & -19323 & -17019 & -17290 & -16729 & -17136 & -18524 & -13477 & -10690 \\
\hline PIB & 192843 & 212139 & 222672 & 243089 & 210139 & 233370 & 234114 & 236565 \\
\hline Taxa de Juros & 22 & 21,220 & 20,890 & 35,770 & 33,280 & 22,930 & 24,620 & 37,180 \\
\hline Taxa de Câmbio & 1 & 1,490 & 1,500 & 1,510 & 1,520 & 1,540 & 1,630 & 1,700 \\
\hline Variação Câmbio & & 0,014 & 0,007 & 0,007 & 0,007 & 0,013 & 0,058 & 0,043 \\
\hline \multicolumn{9}{|l|}{ Reservas Intern. } \\
\hline \multicolumn{9}{|l|}{ Variação Reservas } \\
\hline \multicolumn{9}{|l|}{ INDPRESCAM } \\
\hline \multicolumn{9}{|l|}{ crédito privado } \\
\hline \multicolumn{9}{|l|}{ crédito público } \\
\hline depósitos vista & 24333 & 23720 & 25508 & 27912 & 25869 & 28138 & 27427 & 29059 \\
\hline depósitos prazo & 173646 & 178755 & 194305 & 203992 & 212197 & 222131 & 224586 & 225619 \\
\hline Lucro-prejuízo & 1778 & 3174 & 1486 & -2582 & -1126 & -3311 & 11 & 2432 \\
\hline Ativo em FX & 20637 & 20976 & 19915 & 21810 & 21996 & 21302 & 22686 & 21284 \\
\hline Passivo em FX & 39960 & 37995 & 37205 & 38539 & 39132 & 39826 & 36163 & 31974 \\
\hline Ativo em TJ & 578292 & 626057 & 645405 & 633298 & 638905 & 655987 & 630872 & 626285 \\
\hline Passivo em TJ & 522414 & 572346 & 588302 & 576379 & 586084 & 600464 & 581538 & 570709 \\
\hline Expos. Taxa Juros & 55878 & 53711 & 57103 & 56919 & 52820 & 55524 & 49334 & 55576 \\
\hline \multicolumn{9}{|l|}{ Indicador Contábil } \\
\hline ROE & & & & & $-0,0315$ & $-0,0895$ & 0,0003 & 0,0542 \\
\hline ATPL & & & & & 18,5208 & 18,3053 & 18,2269 & 14,4269 \\
\hline ALDT & & & & & 0,7754 & 0,8197 & 0,7169 & 0,7544 \\
\hline CAOC & & & & & 0,4638 & 0,5955 & 0,4257 & 0,5704 \\
\hline NOPPL & & & & & $-0,4802$ & $-0,5007$ & $-0,3759$ & $-0,2382$ \\
\hline \multicolumn{9}{|l|}{ Indicador de Riscos } \\
\hline IRFX(4,99\%) & & & & & $-7,5991$ & $-7,4750$ & $-4,7875$ & $-3,2854$ \\
\hline IRTJ(4,99\%) & & & & & 23,4235 & 22,4057 & 17,5251 & 17,0806 \\
\hline $\operatorname{IRCRE}(4,99 \%)$ & & & & & 1,0063 & 1,3120 & 1,0437 & 0,6610 \\
\hline IRDTAL & & & & & 0,1813 & 0,1390 & 0,0750 & 0,0498 \\
\hline IRATPIB & & & & & 3,2209 & 2,9835 & 2,8852 & 2,8470 \\
\hline
\end{tabular}

Fonte: http://www.bcb.gov.br/fis/top50; IMF (2003). 


\section{PAÍS COM EXPERIÊNCIA DE CRISE}

5. Coréia do Sul - dez/1997

Em milhões de wons

Variáveis TRIM-8 TR

\begin{tabular}{|c|c|c|c|c|c|c|c|c|}
\hline Patrimônio Líquido & 22523 & 27399 & 28965 & 30140 & 24877 & 30745 & 32841 & 33873 \\
\hline Ativo Total & 379517 & 376954 & 399637 & 432302 & 451180 & 451306 & 467500 & 486929 \\
\hline Passivo & 356994 & 349555 & 370673 & 402163 & 426303 & 420561 & 434659 & 453056 \\
\hline Ativos Líquidos & 37333 & 31157 & 29576 & 34442 & 38568 & 30479 & 32244 & 29151 \\
\hline Oper. de Créd. & 206142 & 210846 & 221890 & 239790 & 245833 & 260131 & 269033 & 282685 \\
\hline Créditos Anormais & 0,0760 & 0,0755 & 0,0586 & 0,0565 & 0,0441 & 0,0285 & 0,0278 & 0,0283 \\
\hline Depósitos Totais & 138744 & 137909 & 146541 & 153781 & 162990 & 168271 & 174158 & 183188 \\
\hline Expos. Câmbio & -2820 & -3205 & -4735 & -6682 & -7827 & -8494 & -9149 & -8992 \\
\hline PIB & 106674 & 94533 & 102169 & 104870 & 116907 & 101061 & 110337 & 113227 \\
\hline Taxa de Juros & 11,27 & 10,53 & 11,15 & 14,22 & 13,85 & 11,94 & 12,21 & 12,38 \\
\hline Taxa de Câmbio & 775 & 783 & 811 & 821 & 844 & 897 & 888 & 915 \\
\hline Variação Câmbio & & 0,010 & 0,036 & 0,013 & 0,028 & 0,063 & $-0,010$ & 0,030 \\
\hline Reservas Intern. & 21995 & 22882 & 25319 & 22819 & 23682 & 21566 & 24555 & 22271 \\
\hline Variação Reservas & & 0,040 & 0,107 & $-0,099$ & 0,038 & $-0,089$ & 0,139 & $-0,093$ \\
\hline INDPRESCAM & & $-0,030$ & $-0,071$ & 0,112 & $-0,010$ & 0,152 & $-0,149$ & 0,123 \\
\hline crédito privado & 200769 & 205540 & 216794 & 234938 & 240936 & 255289 & 263903 & 277323 \\
\hline crédito público & 5373 & 5306 & 5096 & 4852 & 4897 & 4842 & 5130 & 5362 \\
\hline depósitos vista & 23672 & 20488 & 21376 & 22085 & 24221 & 21397 & 22653 & 20940 \\
\hline depósitos prazo & 115072 & 117421 & 125165 & 131696 & 138769 & 146874 & 151505 & 162248 \\
\hline Lucro-prejuízo & & 4876 & 1566 & 1175 & -5262 & 5868 & 2096 & 1032 \\
\hline Ativo em FX & 21542 & 23119 & 24383 & 25481 & 28627 & 29324 & 30012 & 31937 \\
\hline Passivo em FX & 24361 & 26324 & 29118 & 32163 & 36454 & 37818 & 39161 & 40929 \\
\hline Ativo em TJ & 357975 & 353835 & 375254 & 406821 & 422554 & 421982 & 437488 & 454992 \\
\hline Passivo em TJ & 332633 & 323232 & 341555 & 369999 & 389849 & 382743 & 395498 & 412127 \\
\hline Expos. Taxa Juros & 25343 & 30604 & 33700 & 36822 & 32705 & 39239 & 41990 & 42865 \\
\hline Assist. Financ. BC & 28429 & 27847 & 27347 & 27682 & 24460 & 19586 & 20560 & 22178 \\
\hline \multicolumn{9}{|l|}{ Indicador Contábil } \\
\hline ROE & & & & & $-0,212$ & 0,191 & 0,064 & 0,030 \\
\hline ATPL & & & & & 18,136 & 14,679 & 14,235 & 14,375 \\
\hline ALDT & & & & & 0,087 & 0,065 & 0,067 & 0,038 \\
\hline $\mathrm{CAOC}$ & & & & & 0,044 & 0,028 & 0,028 & 0,028 \\
\hline NOPPL & & & & & $-0,315$ & $-0,276$ & $-0,279$ & $-0,265$ \\
\hline \multicolumn{9}{|l|}{ Indicador de Riscos } \\
\hline IRFX $(4,99 \%)$ & & & & & $-1,186$ & $-0,818$ & $-0,640$ & $-0,455$ \\
\hline $\operatorname{IRTJ}(4,99 \%)$ & & & & & 4,954 & 3,780 & 2,938 & 2,171 \\
\hline $\operatorname{IRCRE}(4,99 \%)$ & & & & & 0,258 & 0,237 & 0,228 & 0,134 \\
\hline IRDTAL & & & & & 1,525 & 1,788 & 1,493 & 2,505 \\
\hline IRATPIB & & & & & 4,431 & 4,952 & 4,500 & 4,603 \\
\hline
\end{tabular}

Fontes: http://www.bok.or.kr/eng/index.jsp/; IMF (2003). 


\section{PAÍS COM EXPERIÊNCIA DE CRISE}

\section{Croácia - dez/1998}

Variáveis

Patrimônio Líquid

Ativo Total

Passivo

Ativos Líquidos

Oper. de Créd.

Créditos Anormais

Depósitos Totais

Expos. Câmbio

PIB

Taxa de Juros

Taxa de Câmbio

Variação Câmbio

Reservas Intern.

Variação Reservas

INDPRESCAM

crédito privado

crédito público

depósitos vista

depósitos prazo

Lucro-prejuízo

Ativo em FX

Passivo em FX

Ativo em TJ

Passivo em TJ

Expos. Taxa Juros

Assist. Financ. BC

Indicador Contábil

ROE

ATPL

ALDT

CAOC

NOPPL

Indicador de Riscos

IRFX $(4,99 \%)$

$\operatorname{IRTJ}(4,99 \%)$

IRCRE $(4,99 \%)$

IRDTAL

IRATPIB

Fonte: http://www.hnb.hr/supervizija/esupervizija.htm; IMF (2003).
Em milhões de kunas

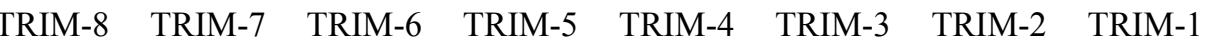

$\begin{array}{rrrrrrrr}15441 & 15571 & 16194 & 16370 & 17027 & 17614 & 18835 & 19146 \\ 67483 & 69558 & 74540 & 81187 & 85309 & 88555 & 90884 & 93110 \\ 52042 & 53986 & 58347 & 64816 & 68282 & 70941 & 72049 & 73964 \\ 4410 & 3879 & 4267 & 4503 & 5046 & 4548 & 4502 & 5238 \\ 42232 & 44345 & 48638 & 52152 & 57363 & 61213 & 64677 & 66653 \\ & 0,0723 & 0,0826 & 0,0985 & 0,1034 & 0,1248 & 0,1541 & 0,1701 \\ 10394 & 10372 & 11473 & 13298 & 14023 & 13662 & 13607 & 14214 \\ -21735 & -23732 & -26359 & -24851 & -28899 & -33300 & -35411 & -37380 \\ & 27120 & 29922 & 32518 & 34252 & 31495 & 34119 & 36625 \\ 9,72 & 10,91 & 10,73 & 8,78 & 8,43 & 9,57 & 12,80 & 11,25 \\ 5,54 & 5,47 & 6,17 & 6,24 & 6,30 & 6,49 & 6,60 & 6,17 \\ & -0,013 & 0,128 & 0,011 & 0,010 & 0,030 & 0,017 & -0,065 \\ 1609 & 1624 & 1676 & 1822 & 1882 & 1840 & 1915 & 2011 \\ & 0,009 & 0,032 & 0,087 & 0,033 & -0,022 & 0,041 & 0,050 \\ & -0,022 & 0,096 & -0,076 & -0,023 & 0,053 & -0,024 & -0,115 \\ 42232 & 44345 & 48638 & 52152 & 57363 & 61213 & 64677 & 66653\end{array}$

\begin{tabular}{|c|c|c|c|c|c|c|c|}
\hline 7007 & 6410 & 7048 & 7999 & 8424 & 7772 & 8055 & 8271 \\
\hline \multirow[t]{2}{*}{3387} & 3962 & 4425 & 5299 & 5599 & 5890 & 5553 & 5944 \\
\hline & 131 & 622 & 176 & 657 & 587 & 1220 & 311 \\
\hline 12550 & 13471 & 14074 & 17355 & 16186 & 16426 & 15469 & 15576 \\
\hline 34285 & 37203 & 40433 & 42206 & 45085 & 49726 & 50879 & 52955 \\
\hline 54933 & 56087 & 60467 & 63832 & 69123 & 72129 & 75416 & 77534 \\
\hline 17757 & 16784 & 17914 & 22610 & 23197 & 21214 & 21170 & 21009 \\
\hline 37176 & 39303 & 42553 & 41222 & 45926 & 50915 & 54246 & 56526 \\
\hline \multirow[t]{11}{*}{2117} & 2000 & 2801 & 6908 & 7042 & 7420 & 7846 & 8357 \\
\hline & & & & 0,039 & 0,033 & 0,065 & 0,016 \\
\hline & & & & 5,010 & 5,027 & 4,825 & 4,863 \\
\hline & & & & $-0,142$ & $-0,210$ & $-0,246$ & $-0,219$ \\
\hline & & & & 0,103 & 0,125 & 0,154 & 0,170 \\
\hline & & & & $-1,697$ & $-1,891$ & $-1,880$ & $-1,952$ \\
\hline & & & & $-4,502$ & $-4,096$ & $-7,575$ & $-7,507$ \\
\hline & & & & 7,154 & 6,263 & 11,605 & 11,353 \\
\hline & & & & 0,098 & 0,122 & 0,175 & 0,209 \\
\hline & & & & $-1,688$ & $-0,796$ & $-0,179$ & $-0,188$ \\
\hline & & & & 2,902 & 3,199 & 2,913 & 2,72 \\
\hline
\end{tabular}




\section{PAÍS COM EXPERIÊNCIA DE CRISE}

7. Equador - mar/1999

Em milhões de sóis

Variáveis

TRIM-8 $\quad$ TRIM-7 $\quad$ TRIM-6 $\quad$ TRIM-5 $\quad$ TRIM-4 $\quad$ TRIM-3 $\quad$ TRIM-2 $\quad$ TRIM-1

\begin{tabular}{lllllllll}
\hline Patrimônio Líquido & 1482130 & 1522170 & 1699030 & 1760060 & 1813200 & 1800620 & 1584370 & 1719820
\end{tabular}

Ativo Total

Passivo

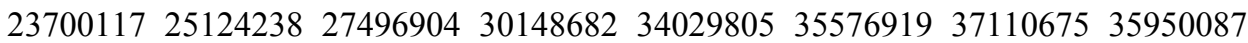

Ativos Líquidos Oper. de Créd.

Créditos Anormais

Depósitos Totais

Expos. Câmbio

PIB

Taxa de Juros

Taxa de Câmbio

Variação Câmbio

Reservas Intern.

Variação Reservas

INDPRESCAM

crédito privado

crédito público

depósitos vista

depósitos prazo

Lucro-prejuízo

Ativo em FX

Passivo em FX

Ativo em TJ

Passivo em TJ

Expos. Taxa Juros

Assist. Financ. BC

Indicador Contábil

ROE

$\mathrm{AT} / \mathrm{PL}$

AL/DT

CA/OC

NOP/PL

Indicador de Riscos

IRFX $(4,99 \%)$

$\operatorname{IRTJ}(4,99 \%)$

IRCRE $(4,99 \%)$

IRDTAL

IRATPIB

Fontes: http://www.bce.fin.ec/frame.php?CNT=ARB0000368; IMF (2003).

$\begin{array}{llllllll}22217987 & 23602068 & 25797874 & 28388622 & 32216605 & 33776299 & 35526305 & 34230267\end{array}$ $\begin{array}{llllllllll}4902766 & 5528801 & 5587136 & 5436899 & 6676037 & 6811007 & 7346585 & 6837574\end{array}$ 1879735119595437219097682471178327353768287659122976409029112513

$\begin{array}{rrrrrrrr}0 & 0,0828 & 0,0768 & 0,06659 & 0,0683 & 0,0750 & 0,0810 & 0,0904 \\ 4994779 & 5090944 & 5188624 & 5293872 & 5052727 & 4919516 & 4462547 & 4582999 \\ 10226 & -61258 & -170723 & -251153 & -388669 & -570371 & -600796 & -459223 \\ 4915740 & 4904640 & 4886980 & 5051830 & 5013150 & 5043970 & 5022070 & 4707650 \\ 47 & 45,000 & 39,650 & 37,460 & 40,770 & 44,130 & 52,970 & 61,840 \\ 3801 & 3989,000 & 4142,000 & 4428,000 & 4887,000 & 5275,000 & 6255,000 & 6825,000 \\ & 0,049 & 0,038 & 0,069 & 0,104 & 0,079 & 0,186 & 0,091 \\ 1416 & 1662 & 1668 & 1566 & 1482 & 1388 & 1158 & 1165 \\ & 0,173 & 0,004 & -0,061 & -0,053 & -0,064 & -0,166 & 0,006 \\ & -0,124 & 0,035 & 0,130 & 0,157 & 0,143 & 0,352 & 0,085\end{array}$

$18797351 \quad 19595437219097682471178327353768287659122976409029112513$

$\begin{array}{rrrrrrrr}786739 & 833894 & 874114 & 883282 & 764547 & 762666 & 635007 & 728989 \\ 4208040 & 4257050 & 4314510 & 4410590 & 4288180 & 4156850 & 3827540 & 3854010 \\ & 40040 & 176860 & 61030 & 53140 & -12580 & -216250 & 135450 \\ 746906 & 827352 & 828287 & 866707 & 978131 & 940679 & 980494 & 901377 \\ 736680 & 888610 & 999010 & 1117860 & 1366800 & 1511050 & 1581290 & 1360600 \\ 22953211 & 24296886 & 26668617 & 29281975 & 33051674 & 34636240 & 36130181 & 35048710 \\ 21481307 & 22713458 & 24798864 & 27270762 & 30849805 & 32265249 & 33945015 & 32869667 \\ 1471904 & 1583428 & 1869753 & 2011213 & 2201869 & 2370991 & 2185166 & 2179043 \\ 21430 & 19455 & 17803 & 18062 & 36789 & 35537 & 34312 & 34518 \\ & & & & & & & \\ & & & & 0,0293 & -0,0070 & -0,1365 & 0,0788 \\ & & & & 18,7678 & 19,7581 & 23,4230 & 20,9034 \\ & & & & 1,3140 & 1,3773 & 1,6386 & 1,4844 \\ & & & & 0,0683 & 0,0750 & 0,0810 & 0,0904 \\ & & & & -0,2144 & -0,3168 & -0,3792 & -0,2670 \\ & & & & -1,3677 & -1,7837 & -5,1425 & -5,1032 \\ & & & & 7,7484 & 7,4146 & 18,7039 & 24,2151 \\ & & & & 0,2310 & 0,1609 & 0,2512 & 0,3207 \\ & & & & 0,0328 & 0,0485 & 0,0964 & 0,0823 \\ & & & 8,3250 & 8,5229 & 8,5906 & 8,1817\end{array}$




\section{PAÍS COM EXPERIÊNCIA DE CRISE}

8. Finlândia - set/1992

Em milhões de marka

Variáveis TRIM-8

\begin{tabular}{|c|c|c|c|c|c|c|c|c|}
\hline Patrimônio Líquido & 39098 & 40591 & 45677 & 47343 & 50563 & 51979 & 53350 & 57430 \\
\hline Ativo Total & 583966 & 606263 & 682451 & 707347 & 734003 & 754557 & 770391 & 829310 \\
\hline Passivo & 544868 & 565672 & 636774 & 660004 & 683440 & 702578 & 717041 & 771879 \\
\hline Ativos Líquidos & 125023 & 127960 & 145842 & 132328 & 143712 & 154444 & 171835 & 231413 \\
\hline Oper. de Créd. & 369240 & 385174 & 404955 & 438562 & 451846 & 457791 & 471224 & 460826 \\
\hline Créditos Anormais & 0,0374 & 0,0391 & 0,0396 & 0,0426 & 0,0624 & 0,0653 & 0,0794 & 0,0811 \\
\hline Depósitos Totais & 204946 & 209993 & 218087 & 226352 & 228976 & 151912 & 158200 & 155450 \\
\hline Expos. Câmbio & -76432 & -82156 & -82558 & -104358 & -119580 & -114150 & -120601 & -107283 \\
\hline PIB & 117510 & 124020 & 134140 & 131470 & 135120 & 125770 & 126790 & 122310 \\
\hline Taxa de Juros & 11,02 & 11,88 & 15,01 & 13,08 & 14,41 & 12,40 & 13,94 & 13,88 \\
\hline Taxa de Câmbio & 5,18 & 5,17 & 5,45 & 5,63 & 5,54 & 5,91 & 6,15 & 5,94 \\
\hline Variação Câmbio & & $-0,002$ & 0,054 & 0,033 & $-0,016$ & 0,067 & 0,041 & $-0,034$ \\
\hline Reservas Intern. & 26568 & 27193 & 29863 & 27096 & 22400 & 24073 & 27162 & 36580 \\
\hline Variação Reservas & & 0,023 & 0,098 & $-0,093$ & $-0,173$ & 0,075 & 0,128 & 0,347 \\
\hline INDPRESCAM & & $-0,025$ & $-0,044$ & 0,126 & 0,157 & $-0,008$ & $-0,088$ & $-0,381$ \\
\hline crédito privado & 366361 & 382458 & 402750 & 436863 & 449853 & 455541 & 467798 & 456609 \\
\hline crédito público & 2879 & 2716 & 2205 & 1699 & 1993 & 2250 & 3426 & 4217 \\
\hline depósitos vista & 29248 & 34288 & 32634 & 35606 & 34837 & 118476 & 121832 & 119462 \\
\hline depósitos prazo & 204946 & 209993 & 218087 & 226352 & 228976 & 151912 & 158200 & 155450 \\
\hline \multicolumn{9}{|l|}{ Lucro-prejuízo } \\
\hline Ativo em FX & 91504 & 94924 & 90280 & 110280 & 98117 & 125482 & 100316 & 99513 \\
\hline Passivo em FX & 167936 & 177080 & 172837 & 214638 & 217697 & 239632 & 220917 & 206796 \\
\hline Ativo em TJ & 492462 & 511339 & 592172 & 597067 & 635886 & 629075 & 670075 & 729797 \\
\hline Passivo em TJ & 376932 & 388592 & 463937 & 445366 & 465743 & 462946 & 496124 & 565083 \\
\hline Expos. Taxa Juros & 115530 & 122747 & 128235 & 151701 & 170143 & 166129 & 173951 & 164713 \\
\hline Assist. Financ. BC & 30671 & 32779 & 52895 & 36769 & 33476 & 29984 & 26962 & 24138 \\
\hline \multicolumn{9}{|l|}{ Indicador Contábil } \\
\hline ROE & & & & & 0,058 & 0,052 & $-0,091$ & $-0,481$ \\
\hline ATPL & & & & & 14,517 & 14,517 & 14,440 & 14,440 \\
\hline ALDT & & & & & 0,481 & 0,819 & 0,916 & 1,333 \\
\hline CAOC & & & & & 0,062 & 0,065 & 0,079 & 0,081 \\
\hline NOPPL & & & & & $-2,365$ & $-2,196$ & $-2,261$ & $-1,868$ \\
\hline \multicolumn{9}{|l|}{ Indicador de Riscos } \\
\hline $\operatorname{IRFX}(4,99 \%)$ & & & & & $-6,735$ & $-5,239$ & $-3,948$ & $-3,153$ \\
\hline IRTJ(4,99\%) & & & & & 9,583 & 7,625 & 5,694 & 4,841 \\
\hline $\operatorname{IRCRE}(4,99 \%)$ & & & & & 0,201 & 0,236 & 0,270 & 0,155 \\
\hline IRDTAL & & & & & 0,157 & 0,593 & 0,585 & 0,360 \\
\hline IRATPIB & & & & & 6,254 & 6,503 & 6,510 & 7,456 \\
\hline
\end{tabular}

* Dados semestrais

Fonte: http://www.bof.fi/eng/5 tilastot/; IMF (2003). 


\section{PAÍS COM EXPERIÊNCIA DE CRISE}

\begin{tabular}{|c|c|c|c|c|c|c|c|c|}
\hline \multicolumn{4}{|c|}{ 9. Indonésia - dez/1997 } & \multicolumn{5}{|c|}{ Em milhões de rúpias } \\
\hline Variáveis & TRIM-8 & TRIM-7 & TRIM-6 & TRIM-5 & TRIM-4 & TRIM-3 & TRIM-2 & TRIM-1 \\
\hline Patrimônio Líquido & 30111 & 31975 & 34062 & 34731 & 37145 & 40935 & 41398 & 44785 \\
\hline Ativo Total & 308618 & 320816 & 339958 & 356469 & 387477 & 399603 & 427031 & 483626 \\
\hline Passivo & 278507 & 288841 & 305896 & 321738 & 350332 & 358668 & 385633 & 438841 \\
\hline Ativos Líquidos & 5140 & 9888 & 9825 & 10482 & 11881 & 12505 & 17495 & 16627 \\
\hline Oper. de Créd. & 260298 & 265940 & 283216 & 297290 & 318594 & 328787 & 352421 & 396912 \\
\hline Créditos & 0,1196 & 0,1210 & 0,1473 & 0,1663 & 0,1814 & 0,1876 & 0,2688 & 0,3004 \\
\hline Depósitos Totais & 162421 & 169466 & 183571 & 193221 & 216140 & 219639 & 233038 & 229008 \\
\hline Expos. Câmbio & -48898 & -53484 & -54372 & -53966 & -58496 & -64623 & -70554 & -97683 \\
\hline PIB & 119183 & 122530 & 128846 & 136940 & 144253 & 145801 & 149406 & 163252 \\
\hline Taxa & 13,99 & 3,99 & 13,99 & 13,96 & 12,80 & 1,07 & 10,50 & 22,00 \\
\hline Таха & 2308 & 2337 & 2342 & 2340 & 2383 & 2419 & 2450 & 3275 \\
\hline Variaç & & 0,013 & 0,002 & $-0,001$ & 0,018 & 015 & 0,013 & 0,337 \\
\hline Reserv & 9330 & 10342 & 10903 & 10870 & 12801 & 13817 & 14759 & 14960 \\
\hline Varia & & 0,108 & 0,054 & $-0,003$ & 0,178 & & 0,068 & 0,014 \\
\hline INDPR & & $-0,096$ & $-0,052$ & 0,002 & $-0,159$ & $-0,064$ & $-0,055$ & 0,323 \\
\hline crédito & 247434 & 252689 & 265409 & 279441 & 299261 & 311108 & 333173 & 378999 \\
\hline rédit & 12864 & 13251 & 17807 & 17849 & 19333 & & 9248 & 17913 \\
\hline еро & 31530 & 31662 & 34839 & 8209 & 41172 & 39871 & 45735 & 41964 \\
\hline depósi & 130891 & 137804 & 148732 & 155012 & 174968 & 179768 & 187303 & 187044 \\
\hline Lucro & & 1864 & 2087 & 669 & 2414 & 3790 & 463 & 3387 \\
\hline Ativ & 17096 & 15089 & 16576 & 7736 & 20820 & 19264 & 7740 & 27080 \\
\hline Pass & 65994 & 3 & 70948 & 2 & 79316 & 83887 & 88294 & 124763 \\
\hline Ati & 291522 & 7 & 323. & 3 & 366657 & 380 & 409291 & 456546 \\
\hline Pas & 212513 & 220 & 234 & 36 & 271016 & & 339 & 314078 \\
\hline $\operatorname{Exp}$ & 79009 & & & & 41 & 105558 & 111952 & 142468 \\
\hline Assist. Finan & 10394 & 11247 & 12241 & 13038 & 11622 & 11966 & 14610 & 23907 \\
\hline & & & & & & & & \\
\hline ROE & & & & & 0,065 &, 093 & 011 & 0,076 \\
\hline ATPL & & & & & 10,431 & 9,762 & 10,315 & 10,799 \\
\hline ALDT & & & & & 0,001 & 0,002 & 0,012 & 0,000 \\
\hline $\mathrm{AO}$ & & & & & 0,181 & 0,188 & 0,269 & 0,300 \\
\hline NOPPL & & & & & $-1,575$ & $-1,579$ & $-1,704$ & $-2,181$ \\
\hline Indicac & & & & & & & & \\
\hline IRFX( & & & & & $-1,854$ & $-4,352$ & $-5,445$ & $-24,295$ \\
\hline (2) & & & & & 3,031 & 7,108 & 8,640 & 35,433 \\
\hline IRCRI & & & & & 0,451 & 0,291 & 0,791 & 1,060 \\
\hline IRDTA & & & & & 152,882 & 65,650 & 11,574 & $-2,187$ \\
\hline IRATPIB & & & & & 3,081 & 3,121 & 3,253 & 3,491 \\
\hline
\end{tabular}

Fontes: http://www.bi.go.id/web/en/Data+Statistik/; IMF (2003). 


\section{PAIIS COM EXPERIÊNCIA DE CRISE}

10. México - dez/1994

Em milhões de pesos mexicanos

Variáveis TRIM

\begin{tabular}{|c|c|c|c|c|c|c|c|c|}
\hline Patrimônio Líquido & 20401 & 20916 & 22692 & 23515 & 27589 & 29592 & 32387 & 31575 \\
\hline Ativo Total & 493626 & 543818 & 565493 & 590166 & 627727 & 651324 & 677979 & 799880 \\
\hline Passivo & 473225 & 522902 & 542801 & 566651 & 600138 & 621732 & 645592 & 768305 \\
\hline Ativos Líquidos & 103187 & 112052 & 116743 & 108583 & 123421 & 122260 & 152577 & 186154 \\
\hline Oper. de Créd. & 294848 & 300290 & 320275 & 331614 & 363269 & 376988 & 371695 & 446572 \\
\hline Créditos Anormais & 0 & 0,0801 & 0,0883 & 0,09355 & 0,0898 & 0,1019 & 0,1047 & 0,0915 \\
\hline Depósitos Totais & 260391 & 273812 & 276210 & 294577 & 302797 & 307236 & 336451 & 351676 \\
\hline Expos. Câmbio & -11752 & -13535 & -16479 & -14444 & -15675 & -18990 & -21589 & -33740 \\
\hline PIB & 1221500 & 1250150 & 1218290 & 1334840 & 1355460 & 1424840 & 1384770 & 1528380 \\
\hline Taxa de Juros & 21 & 18,120 & 16,410 & 14,020 & 10,170 & 18,400 & 17,440 & 19,850 \\
\hline Taxa de Câmbio & 3 & 3,121 & 3,118 & 3,106 & 3,360 & 3,392 & 3,404 & 5,325 \\
\hline Variação Câmbio & & 0,008 & $-0,001$ & $-0,004$ & 0,082 & 0,010 & 0,004 & 0,564 \\
\hline Reservas Intern. & 15239 & 16392 & 16279 & 18298 & 18341 & 11413 & 11174 & 4316 \\
\hline Variação Reservas & & 0,076 & $-0,007$ & 0,124 & 0,002 & $-0,378$ & $-0,021$ & $-0,614$ \\
\hline INDPRESCAM & & $-0,068$ & 0,006 & $-0,128$ & 0,079 & 0,387 & 0,025 & 1,178 \\
\hline crédito privado & 294848 & 300290 & 320275 & 331614 & 363269 & 376988 & 371695 & 446572 \\
\hline crédito público & 19591 & 24045 & 28270 & 31022 & 32632 & 38431 & 38911 & 40879 \\
\hline depósitos vista & 82632 & 86518 & 87972 & 98725 & 95611 & 91904 & 88618 & 91106 \\
\hline depósitos prazo & 177759 & 187294 & 188238 & 195852 & 207186 & 215332 & 247833 & 260570 \\
\hline Lucro-prejuízo & 6267 & 2043 & 4294 & 6523 & 8792 & 2141 & 5053 & 3654 \\
\hline Ativo em FX & 2279 & 2692 & 2873 & 2359 & 3762 & 2942 & 656 & 2315 \\
\hline Passivo em FX & 14031 & 16227 & 19352 & 16803 & 19437 & 21932 & 22245 & 36055 \\
\hline Ativo em TJ & 491347 & 541126 & 562620 & 587807 & 623965 & 648382 & 677323 & 797565 \\
\hline Passivo em TJ & 459194 & 506675 & 523449 & 549848 & 580701 & 599800 & 623347 & 732250 \\
\hline Expos. Taxa Juros & 32153 & 34451 & 39171 & 37959 & 43264 & 48582 & 53976 & 65315 \\
\hline Assist. Financ. BC & 31923 & 34866 & 38387 & 41943 & 45691 & 51480 & 56493 & 99149 \\
\hline \multicolumn{9}{|l|}{ Indicador Contábil } \\
\hline ROE & & & & & 0,3187 & 0,0723 & 0,1560 & 0,1157 \\
\hline ATPL & & & & & 22,7528 & 22,0101 & 20,9337 & 25,3327 \\
\hline ALDT & & & & & 0,2567 & 0,2304 & 0,2856 & 0,2474 \\
\hline CAOC & & & & & 0,0898 & 0,1019 & 0,1047 & 0,0915 \\
\hline NOPPL & & & & & $-0,5682$ & $-0,6417$ & $-0,6666$ & $-1,0686$ \\
\hline \multicolumn{9}{|l|}{ Indicador de Riscos } \\
\hline $\operatorname{IRFX}(4,99 \%)$ & & & & & $-3,8662$ & $-4,3645$ & $-4,7950$ & $-9,8210$ \\
\hline $\operatorname{IRTJ}(4,99 \%)$ & & & & & 10,6710 & 11,1657 & 11,9883 & 19,0119 \\
\hline $\operatorname{IRCRE}(4,99 \%)$ & & & & & 0,1511 & 0,1571 & 0,1615 & 0,2115 \\
\hline IRDTAL & & & & & 0,3663 & 0,3907 & 0,3828 & 0,5440 \\
\hline IRATPIB & & & & & 0,5375 & 0,4983 & 0,5241 & 0,621 \\
\hline
\end{tabular}

Fontes: http://dgcnesyp.inegi.gob.mx/cgi-win/bdieintsi.exe/; IMF (2003). 


\section{PAÍS COM EXPERIÊNCIA DE CRISE}

11. Rússia - set/1998

Variáveis

Patrimônio Líquido

Passivo

Ativos Líquidos

Oper. de Créd.

Créditos Anormais

Depósitos Totais

Expos. Câmbio

PIB

Taxa de Juros

Taxa de Câmbio

Variação Câmbio

Reservas Intern.

Variação Reservas

INDPRESCAM

crédito privado

crédito público

depósitos vista

depósitos prazo

Lucro-prejuízo

Ativo em FX

Passivo em FX

Ativo em TJ

Passivo em TJ

Expos. Taxa Juros

Assist. Financ. BC

Indicador Contábil

ROE

ATPL

ALDT

CAOC

NOPPL

Indicador de Riscos

$\operatorname{IRFX}(4,99 \%)$

IRTJ $(4,99 \%)$

IRCRE $(4,99 \%)$

IRDTAL

IRATPIB

Fontes: http://www.cbr.ru/eng/; IMF (2003).
Em milhões de rublos

\begin{tabular}{llllllll} 
TRIM-8 & TRIM-7 & TRIM-6 & TRIM-5 & TRIM-4 & TRIM-3 & TRIM-2 & TRIM-1 \\
\hline
\end{tabular}

$\begin{array}{rrrrrrrr}109574 & 123818 & 128089 & 140208 & 144171 & 143909 & 153008 & 156157 \\ 345750 & 395843 & 395620 & 427470 & 449592 & 475221 & 511403 & 477149 \\ 236176 & 272025 & 267531 & 287262 & 305421 & 331312 & 358395 & 320992 \\ 206285 & 246722 & 242527 & 265345 & 278864 & 290945 & 212988 & 167616 \\ 139465 & 149122 & 153094 & 162125 & 170728 & 184276 & 298415 & 309533 \\ 0,0828 & 0,0777 & 0,0736 & 0,0651 & 0,0584 & 0,0465 & 0,1103 & 0,1148 \\ 237224 & 252202 & 271182 & 284768 & 298088 & 321248 & 312031 & 312061 \\ 11242 & 13983 & -5261 & -10719 & -29315 & -31480 & -35317 & -32271 \\ 548880 & 565240 & 512370 & 555080 & 634160 & 640910 & 550870 & 602450 \\ 46,80 & 31,67 & 26,43 & 19,70 & 15,37 & 22,37 & 26,77 & 44,40 \\ 5 & 6 & 6 & 6 & 6 & 6 & 6 & 6 \\ & 0,029 & 0,030 & 0,009 & 0,014 & 0,017 & 0,025 & 0,015 \\ 834808 & 831412 & 943602 & 1517740 & 1423420 & 1012730 & 949302 & 896594 \\ & -0,004 & 0,135 & 0,608 & -0,062 & -0,289 & -0,063 & -0,056 \\ 0 & 0,033 & -0,105 & -0,599 & 0,076 & 0,305 & 0,087 & 0,071 \\ 143473 & 157337 & 163572 & 179619 & 205202 & 236439 & 239196 & 249256 \\ 199045 & 220092 & 243093 & 259127 & 263540 & 227907 & 240007 & 237927 \\ 78914 & 87303 & 90977 & 104011 & 116160 & 162532 & 142683 & 136714 \\ 158310 & 164899 & 180205 & 180757 & 181928 & 158716 & 169348 & 175347 \\ & 847 & 2915 & 261 & 1660 & 2999 & 5308 & -4140 \\ 58972 & 72875 & 49700 & 56549 & 63179 & 72717 & 68263 & 73126 \\ 47730 & 58892 & 54961 & 67268 & 92494 & 104197 & 103580 & 105397 \\ 286778 & 322968 & 345920 & 370921 & 386413 & 402504 & 443140 & 404023 \\ 188446 & 213133 & 212570 & 219994 & 212927 & 227115 & 254815 & 215595 \\ 98332 & 109835 & 133350 & 150927 & 173486 & 175389 & 188325 & 188428 \\ 5828 & 6799 & 5450 & 4260 & 2352 & 8780 & 4443 & 10451 \\ & & & & & & & \\ & & & & 0,012 & 0,021 & 0,035 & -0,027 \\ & & & & 3,118 & 3,302 & 3,342 & 3,056 \\ & & & & 0,928 & 0,878 & 0,668 & 0,504 \\ & & & & -0,058 & 0,047 & 0,110 & 0,115 \\ & & & & -0,219 & -0,231 & -0,207 \\ & & & & -2,960 & -2,055 & -2,229 & -5,160 \\ & & & & 17,516 & 11,448 & 11,884 & 30,131 \\ & & & & 0,021 & 0,030 & 0,110 & 0,140 \\ & & & & 0,793 & 0,153 & 0,155 & 0,123 \\ & & & & & & \\ & & & & & & \end{array}$




\section{PAÍS COM EXPERIÊNCIA DE CRISE}

\begin{tabular}{|c|c|c|c|c|c|c|c|c|}
\hline \multicolumn{4}{|c|}{ 12. Tailândia - dez/1997 } & \multicolumn{5}{|c|}{ Em milhões de thai baht } \\
\hline Variáveis & TRIM-8 & TRIM-7 & TRIM-6 & TRIM-5 & TRIM-4 & TRIM-3 & TRIM-2 & TRIM-1 \\
\hline Patrimônio Líquido & 471309 & 486949 & 519503 & 595931 & 600169 & 587824 & 598990 & 631368 \\
\hline Ativo Total & 5066546 & 5262799 & 5419341 & 5508052 & 5717254 & 5972605 & 6189639 & 6814571 \\
\hline Passivo & 4595237 & 4775850 & 4899838 & 4912121 & 5117085 & 5384781 & 5590650 & 6183203 \\
\hline Ativos Líquidos & 366018 & 378964 & 369860 & 395858 & 437960 & 537285 & 646383 & 825231 \\
\hline Oper. de Créd. & 4238275 & 4368568 & 4536003 & 4625155 & 4821287 & 4929908 & 4991171 & 5412996 \\
\hline Créditos Anormais & 0,0180 & 0,0181 & 0,0187 & 0,0191 & 0,0194 & 0,0267 & 0,0279 & 0,0294 \\
\hline Tepósitos Totais & 2905703 & 3036963 & 3116223 & 3161911 & 3257780 & 3348286 & 3505001 & 3680519 \\
\hline xpos. Câmbio & -928234 & -919698 & -964229 & -1007128 & -1069309 & -1154141 & -1148580 & -1318120 \\
\hline IB & 1093140 & 1116550 & 1146090 & 1154270 & 1194120 & 1158080 & 1165720 & 1182020 \\
\hline axa & 10,17 & 7,30 & 7,24 & 41 & 10,98 & 11,31 & 11,99 & 19,32 \\
\hline axa & 25,19 & 25,23 & 25,36 &, 42 & 25,61 & 25,97 & 25,79 & 6,52 \\
\hline Varia & & 0,002 & 0,005 & 0,002 & 0,007 & 0,014 & $-0,007$ & 0,416 \\
\hline eservas Intern. & 24293 & 26050 & 26960 & 26830 & 26326 & 26818 & 22679 & 21052 \\
\hline Reservas & & 0,072 & 0,035 & $-0,005$ & $-0,019$ & 0,019 & $-0,154$ & $-0,072$ \\
\hline NDPRESCAM & & $-0,071$ & $-0,030$ & 0,007 & 0,026 & $-0,005$ & 0,147 & 0,488 \\
\hline rivado & 4089203 & 4227696 & 4394813 & 4498533 & 4688334 & 4812645 & 4872889 & 5301506 \\
\hline édi & 149072 & 140873 & 141189 & 126622 & 132953 & 117263 & 118282 & 111490 \\
\hline depós & 85833 & 106232 & 86814 & 103549 & 87298 & 91788 & 81552 & 79202 \\
\hline depós & 2819870 & 2930732 & 3029409 & 3058363 & 3170482 & 3256498 & 3423449 & 3601318 \\
\hline Lucro & & 15640 & 32554 & 76428 & 58167 & -12345 & 35600 & 32379 \\
\hline Ativo & 235898 & 262370 & 259607 & 206154 & 179985 & 184402 & 198379 & 290915 \\
\hline em FX & 1164132 & 1182068 & 1223836 & 1213281 & 1249294 & 1338543 & 1346958 & 1609035 \\
\hline Ativo & 4830647 & 5000429 & 5159734 & 5301899 & 5537269 & 5788203 & 5991261 & 6523655 \\
\hline Passivo em TJ & 3431105 & 3593782 & 3676002 & 3698840 & 3867791 & 4046239 & 4243692 & 4574168 \\
\hline xpc & 1399543 & 1406647 & 1483733 & 1603059 & 1669477 & 1741964 & 1747569 & 1949488 \\
\hline Assi & 233559 & 226722 & 252571 & 236648 & 282005 & 259943 & 290149 & 474745 \\
\hline & & & & & & & & \\
\hline ROE & & & & & 0,097 & & & 0,051 \\
\hline $\mathrm{Tl}$ & & & & & 9,526 & & 333 & 10,793 \\
\hline ALI & & & & & 0,048 & & 0,102 & 0,095 \\
\hline & & & & & & & 0,028 & 0,029 \\
\hline TOPPL & & & & & $-1,782$ & $-1,963$ & $-1,918$ & $-2,088$ \\
\hline & & & & & & & & \\
\hline IRFX & & & & & 8,171 & $-7,948$ & $-1,611$ & $-17,580$ \\
\hline RTJ ( & & & & & 12,758 & 11,995 & 2,451 & 26,001 \\
\hline $\operatorname{IRCRE}(4,99 \%$ & & & & & 0,010 & 0,065 & 0,079 & 0,077 \\
\hline IRD] & & & & & 1,193 & 0,752 & 0,827 & 1,069 \\
\hline IRATPIB & & & & & 5,108 & 5,586 & 5,824 & 6,566 \\
\hline
\end{tabular}

Fonte: http://www.bot.or.th/bothomepage/databank/EconData/EconData_e.htm; IMF (2003). 


\section{PAÍS COM EXPERIÊNCIA DE CRISE}

\begin{tabular}{|c|c|c|c|c|c|c|c|c|}
\hline \multicolumn{5}{|c|}{ 13. Turquia - mar/2001 } & \multicolumn{4}{|c|}{ Em bilhões de liras turcas } \\
\hline Variáveis & TRIM-8 & TRIM-7 & TRIM-6 & TRIM-5 & TRIM-4 & TRIM-3 & TRIM-2 & TRIM-1 \\
\hline Patrimônio Líquido & 4413350 & 4831650 & 5552730 & 6644760 & 7249680 & 7196210 & 8261300 & 9627600 \\
\hline tal & 38852797 & 46677251 & 54285329 & 68274579 & 73067234 & 79916586 & 24126 & 99570692 \\
\hline issivo & 34439447 & 41845601 & 48732599 & 61629819 & 65817554 & 72720376 & 826 & \\
\hline Líquidos & 13095416 & 16344183 & 19849275 & 24556006 & 26875973 & 29127181 & 623 & 31 \\
\hline per. & 25757381 & 30333068 & 34436054 & 437 & 46191261 & 50789405 & & 6768 \\
\hline Crédito & 0,1011 & 0,1059 & 0,0947 & 68 & 0,1067 & 0,1049 & 0,0998 & 0,1243 \\
\hline epós & 11643010 & 14175910 & 17214240 & 20452940 & 20554540 & 22159170 & 23829780 & 287 \\
\hline $\mathrm{p}$ & -1605010 & -159 & -2120060 & -17( & -1729660 & $-27 c$ & 700 & \\
\hline $\mathrm{B}$ & 11999400 & 16362000 & 25672600 & 233 & 21096600 & 27444200 & 2000 & \\
\hline $\mathrm{ax}$ & 77,53 &, 94 &, 88 & 77 & 42,02 & 0,30 &, 86 &, 72 \\
\hline & 368269 & 0350 & 9497 & 00 & 589478 & 588 & 491 & 385 \\
\hline Varia & & 0,141 & 93 & & 0,089 & 51 & 077 & 0,009 \\
\hline Reser & 15,8716 & 16,3164 & 17,1755 & & 17,2903 & 18,6330 & 193 & 17,3910 \\
\hline rvas & & 0,028 & 0,053 & & 0,009 & 0,078 & 10 & $-0,076$ \\
\hline INDI & & 0,113 & 0,040 & 0,180 & 0,080 & $-0,027$ & 0,067 & 0,085 \\
\hline réc & 14157003 & 15785803 & 17570437 & 19924562 & 22598372 & 25975907 & 158 & 652 \\
\hline réc & 11600378 & 14547265 & 617 & & 23592889 & 248 & 2345 & 792 \\
\hline ep & 1334310 & 1431110 & 1626540 & & 2637140 & 470 & 6780 & 370 \\
\hline 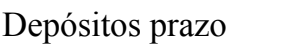 & 10308700 & 12744800 & 15587700 & 176 & 17917400 & 19109700 & 3000 & 300 \\
\hline & 291282 & 641033 & 1196122 & & 227474 & 25335 & 7157 & 838 \\
\hline & 4299890 & 4718820 & & & 8574140 & 0480 & 600 & 000 \\
\hline & 5904900 & & & & 10303800 & 5100 & 300 & 5200 \\
\hline & 34552907 & 41958431 & 48683229 & 601 & 64493094 & 6106 & 1526 & 6692 \\
\hline Pas: & 28534547 & 35531011 & 41010439 & 51842589 & 55513754 & 60975276 & 8526 & 5892 \\
\hline & 6018360 & & 790 & & 8979340 & 9990830 & 11723000 & 9800 \\
\hline & 1144940 & 735080 & 820060 & 2334560 & 2376290 & 2836790 & 2964300 & 5599580 \\
\hline & & & & & & & & \\
\hline ROE & & & & & & & & \\
\hline & & & & & 10,079 & & & 10,342 \\
\hline $\mathrm{J}$ & & & & & 1,192 & 86 & & 0,916 \\
\hline & & & & & & & & 0,124 \\
\hline . & & & & $-0,257$ & $-0,239$ & $-0,388$ & $-0,419$ & $-0,411$ \\
\hline & & & & & & & & \\
\hline & & & & & $-7,454$ & & & $-27,052$ \\
\hline $\operatorname{IRTJ}(4,99 \%)$ & & & & 10,883 & 38,696 & 46,513 & 42,371 & 92,952 \\
\hline$y_{1}$ & & & & 0,124 & 0,116 & 0,129 & 0,097 & 0,152 \\
\hline IRD & & & & 0,346 & 0,250 & 0,159 & 0,120 & 0,271 \\
\hline IRATPIB & & & & 4,002 & 4,632 & 3,709 & 2,500 & 3,404 \\
\hline
\end{tabular}

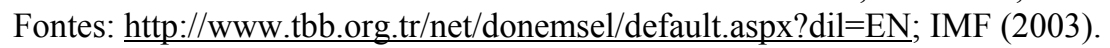




\section{PAIIS COM EXPERIÊNCIA DE CRISE}

14. Uruguai - mar/2002 Em milhões de pesos uruguaios

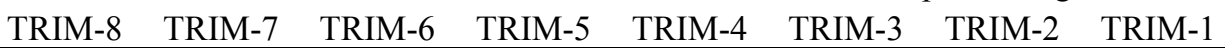

\begin{tabular}{lllllllll}
\hline Patrimônio Líquido & 34837207 & 35103602 & 35595342 & 26892026 & 27400954 & 26735172 & 27097800 & 21355598
\end{tabular} Ativo Total

Passivo

Ativos Líquidos Oper. de Créd.

Créditos Anormais

Depósitos Totais

Expos. Câmbio

PIB

Taxa de Juros

Taxa de Câmbio

Variação Câmbio

Reservas Intern.

Variação Reservas

INDPRESCAM

crédito privado

crédito público

depósitos vista

depósitos prazo

Lucro-prejuízo

Ativo em FX

Passivo em FX

Ativo em TJ

Passivo em TJ

Expos. Taxa Juros

Assist. Financ. BC

Indicador Contábil

ROE

ATPL

ALDT

CAOC

NOPPL

Indicador de Riscos

$\operatorname{IRFX}(4,99 \%)$

$\operatorname{IRTJ}(4,99 \%)$

IRCRE $(4,99 \%)$

IRDTAL

IRATPIB

Fontes: http://www.bcu.gub.uy/autoriza/sieras/boletin/boletines.htm; IMF (2003).

235234518242086038246447697247472015259829465276024263289896788304380356 200397311206982436210852354220579989232428512249289091262798988283024758 $\begin{array}{lllllllll}29476614 & 29919202 & 32035425 & 29191734 & 32368078 & 36308566 & 38564600 & 41177365\end{array}$

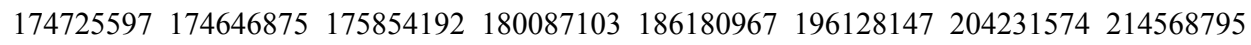
0,077
0,1106
$0,1132 \quad 0,09339 \quad 0,1045$
0,1101
0,1183
0,1137

$\begin{array}{llllllll}106802129 & 111816478 & 113967665 & 121697093 & 129413057 & 140062191 & 147161074 & 163171325\end{array}$

$\begin{array}{llllllll}-6716716 & -8535913 & -8613219 & -11172718 & -10725222 & -12046411 & -12975238 & 11112725\end{array}$

$\begin{array}{llllllll}241279508 & 233716352 & 232826569 & 243027071 & 237423781 & 229860625 & 222000875 & 247211395\end{array}$

$\begin{array}{rrrrrrrr}12 & 11,810 & 19,970 & 15,420 & 13,310 & 13,970 & 31,810 & 29,330 \\ 12 & 12,056 & 12,362 & 12,445 & 12,789 & 13,364 & 13,583 & 14,071 \\ & 0,019 & 0,025 & 0,007 & 0,028 & 0,045 & 0,016 & 0,036 \\ 8880 & 1816510 & 1981320 & 1940390 & 2144610 & 2233730 & 2133720 & 2464680 \\ & 0,088 & 0,091 & -0,021 & 0,105 & 0,042 & -0,045 & 0,155 \\ & -0,068 & -0,065 & 0,027 & -0,078 & 0,003 & 0,061 & -0,119\end{array}$

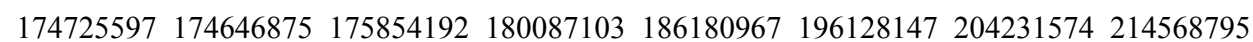

$\begin{array}{rrrrrrrr}6799 & 6688 & 6438 & 7054 & 6806 & 6838 & 6626 & 6641 \\ 98425 & 100170 & 101395 & 105053 & 111593 & 119214 & 120552 & 128570 \\ -302749 & -1380829 & -2109673 & -1268338 & 203745 & -615354 & 3841953 & -6055578 \\ 166367574 & 172305284 & 176963770 & 181817260 & 193168384 & 208207218 & 220374744 & 236320311 \\ 173084290 & 180841197 & 185576989 & 192989979 & 203893606 & 220253630 & 233349982 & 225207586 \\ 68866944 & 69780754 & 69483927 & 65654755 & 66661082 & 67817045 & 69522044 & 68060045 \\ 27313021 & 26141239 & 25275366 & 27590011 & 28534906 & 29035461 & 29449006 & 57817172 \\ 41553923 & 43639515 & 44208562 & 38064744 & 38126176 & 38781584 & 40073038 & 10242873 \\ 10189100 & 10435300 & 10351000 & 10602500 & 10935100 & 11338900 & 11172600 & 11941200\end{array}$

$\begin{array}{rrrr}0,007 & -0,023 & 0,142 & -0,284 \\ 9,482 & 10,324 & 10,698 & 14,253 \\ 0,166 & 0,178 & 0,186 & 0,179 \\ 0,105 & 0,110 & 0,118 & 0,114 \\ -0,391 & -0,451 & -0,479 & 0,520 \\ & & & \\ -2,806 & -2,725 & -8,528 & 10,315 \\ 9,975 & 8,772 & 26,338 & 9,508 \\ 0,121 & 0,129 & 0,159 & 0,118 \\ 0,754 & 0,900 & 0,830 & 0,978 \\ 1,159 & 1,322 & 1,474 & 1,387\end{array}$




\section{PAÍS COM EXPERIÊNCIA DE CRISE}

15. Venezuela - dez/1994

Variáveis *

Patrimônio Líquido

Ativo Total

Passivo

Ativos Líquidos

Oper. de Créd.

Créditos Anormais

Depósitos Totais

Expos. Câmbio

PIB

Taxa de Juros

Taxa de Câmbio

Variação Câmbio

Reservas Intern.

Variação Reservas

INDPRESCAM

crédito privado

crédito público

depósitos vista

depósitos prazo

Lucro-prejuízo

Ativo em FX

Passivo em FX

Ativo em TJ

Passivo em TJ

Expos. Taxa Juros

Assist. Financ. BC

Indicador Contábil

ROE

ATPL

ALDT

CAOC

NOPPL

Indicador de Riscos

$\operatorname{IRFX}(4,99 \%)$

$\operatorname{IRTJ}(4,99 \%)$

$\operatorname{IRCRE}(4,99 \%)$

IRDTAL

IRATPIB

* Dados anuais

Fonte: http://www.bcv.org.ve/c2/indicadores.asp; IMF (2003).

ANO-8

ANO-7

Em milhões de bolívares

$\begin{array}{llllllll}232120 & 288460 & 390580 & 783117 & 1194207 & 1476333 & 1691604 & 2482072\end{array}$

$\begin{array}{llllllll}25150 & 32620 & 41670 & 108250 & 250500 & 279850 & 291610 & 400340\end{array}$

$\begin{array}{llllllll}227160 & 289090 & 339350 & 430620 & 620000 & 836030 & 1079730 & 1388020\end{array}$

$\begin{array}{llllllll}0,0657 & 0,0657 & 0,07753 & 0,0549 & 0,0296 & 0,0656 & 0,1383 & 0,2817\end{array}$

$\begin{array}{llllllll}214150 & 255790 & 365460 & 611610 & 915000 & 1062700 & 1334300 & 2198510\end{array}$

$\begin{array}{llllllll}-50515 & -51049 & -37846 & -41761 & -51060 & -37570 & -20000 & -71771\end{array}$

$\begin{array}{llllllll}679440 & 875500 & 1485540 & 2279260 & 3037490 & 4131480 & 5453900 & 8675170\end{array}$

$\begin{array}{rrrrrrrr}8,000 & 8,000 & 45,000 & 43,000 & 43,000 & 52,200 & 71,250 & 48,000\end{array}$

$\begin{array}{llllllll}20,570 & 19,510 & 56,610 & 71,670 & 88,050 & 109,240 & 145,100 & 248,170\end{array}$

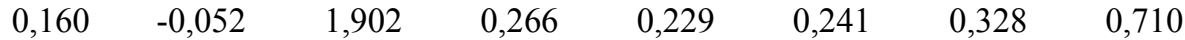

$\begin{array}{lllll}19946 & 16615 & 50794 & 110233 & 192181\end{array}$

$-0,167 \quad 2,057 \quad 1,170 \quad 0,743$

$\begin{array}{llllllll}227160 & 289090 & 339350 & 430620 & 620000 & 836030 & 1079730 & 1388020\end{array}$

$\begin{array}{lllll}597748 & 1029368 & 1251802 & 1423076 & 1991250\end{array}$

$\begin{array}{lllllll}98087 & 109370 & 150905 & 241608 & 245244 & 256542 & 327752\end{array}$

$\begin{array}{lllllll}181848 & 256093 & 460699 & 673391 & 817459 & 1077760 & 1232860\end{array}$

$\begin{array}{lllll}12015 & 16589 & 22224 & 32880 & 60723\end{array}$

$\begin{array}{llllllll}15390 & 19020 & 43190 & 63890 & 84930 & 113190 & 157920 & 192570\end{array}$

$\begin{array}{llllllll}65905 & 70069 & 81036 & 105651 & 135990 & 150760 & 177920 & 264341\end{array}$

$\begin{array}{lllllllll}225530 & 293150 & 378560 & 763547 & 1177417 & 1463513 & 1680544 & 2380052\end{array}$

$\begin{array}{lllllllll}166215 & 218391 & 309544 & 677466 & 1058217 & 1325573 & 1513684 & 2217731\end{array}$

$\begin{array}{llllllll}59315 & 74759 & 69016 & 86081 & 119200 & 137940 & 166860 & 162321\end{array}$

$\begin{array}{llllllll}17970 & 32670 & 25120 & 44640 & 66240 & 72400 & 97870 & 95980\end{array}$

$\begin{array}{rrrrr}0,271 & 0,243 & 0,221 & 0,224 & 0,671 \\ 18,670 & 18,526 & 15,709 & 12,518 & 28,411\end{array}$

$0,104 \quad 0,201 \quad 0,195 \quad 0,145 \quad 0,138$

$\begin{array}{lllll}0,055 & 0,030 & 0,066 & 0,138 & 0,282\end{array}$

$\begin{array}{lllll}-0,942 & -0,749 \quad-0,374 \quad-0,136 & -0,793\end{array}$

$\begin{array}{rrrrr}-40,747 & -27,730 & -3,281 & -3,670 & -19,706 \\ 83,991 & 64,737 & 12,046 & 30,620 & 44,568 \\ 0,181 & 0,375 & 0,343 & 0,692 & 3,449 \\ 5,659 & 3,205 & 3,032 & 3,138 & 3,806 \\ 0,595 & 0,703 & 0,628 & 0,498 & 0,427\end{array}$




\section{PAÍS SEM EXPERIÊNCIA DE CRISE}

\begin{tabular}{|c|c|c|c|c|c|c|c|c|}
\hline \multicolumn{5}{|c|}{ 16. Alemanha - dez/98 } & \multicolumn{4}{|c|}{ Em milhões de marcos alemães } \\
\hline Variáveis & ANO-8 & ANO-7 & ANO-6 & ANO-5 & ANO-4 & ANO-3 & ANO-2 & ANO-1 \\
\hline Patrimônio Líquido & 146444 & 161709 & 187401 & 217654 & 246503 & 267647 & 287905 & 321655 \\
\hline Ativo Total & 3861292 & 4201685 & 4572673 & 5451202 & 5811666 & 6379980 & 7083383 & 7908858 \\
\hline Passivo & 3714848 & 4039976 & 4385272 & 5233548 & 5565163 & 6112333 & 6795478 & 7587203 \\
\hline Ativos Líquidos & 1663220 & 1718110 & 1864547 & 2324609 & 2475633 & 2734306 & 3118597 & 3573091 \\
\hline Oper. de Créd. & 2103045 & 2369096 & 2594859 & 2988906 & 3197909 & 3484013 & 3791309 & 4124950 \\
\hline Créditos & 0,0080 & 0,0059 & 0,0067 & 0,0078 & 0,0094 & 0,0062 & 0,0060 & 0,0062 \\
\hline Depósitos Totais & 2103045 & 2369096 & 2594859 & 2988906 & 3197909 & 3484013 & 3791309 & 4124950 \\
\hline Expos. Câmbio & 252660 & 259130 & 197570 & 303540 & 164260 & 137550 & 180060 & 158960 \\
\hline PIB & 2431200 & 2938000 & 3155200 & 3235400 & 3394400 & 3523000 & 3586000 & 3666560 \\
\hline Taxa de Juros & 7,92 & 8,84 & 9,42 & 7,49 & 5,35 & 4,50 & 3,27 & 3,18 \\
\hline Taxa & 2,13 & 2,17 & 2,22 & 2,37 & 2,26 & 2,13 & 2,24 & 2,42 \\
\hline Variação & & 0,019 & 0,023 & 0,068 & $-0,046$ & $-0,058$ & 0,052 & 0,080 \\
\hline Reser & & & & & & & & \\
\hline & & & & & & & & \\
\hline PDI & & & & & & & & \\
\hline , & & & & & & & & \\
\hline & & & & & & & & \\
\hline Depósitos vista & 391980 & 402280 & 439600 & 484750 & 505310 & 545450 & 631760 & 650040 \\
\hline Depósitos $\mathrm{p}$ & 1176530 & 1261950 & 1337930 & 1500880 & 1523640 & 1572170 & 1649620 & 1692410 \\
\hline Lucro & 8066 & 9711 & 9400 & 13269 & 14926 & 16056 & 16761 & 17051 \\
\hline Ativo & 590860 & 609460 & 624360 & 797490 & 751000 & 828840 & 942240 & 1165380 \\
\hline Passi & 338200 & 350330 & 426790 & 493950 & 586740 & 691290 & 762180 & 1006420 \\
\hline Ativ & 3270432 & 3592 & 3948313 & 465 & 5060666 & 55 & 614 & 6743478 \\
\hline Pas & 76648 & 368 & 395 & 473 & 4978423 & 542 & 603 & 6580783 \\
\hline Exp & -106216 & -9 & -1 & 36 & 82243 & 097 & 107845 & 162695 \\
\hline Assist. Financ. BC & 1078863 & 1150413 & 1252853 & 1477240 & 1627381 & 1862788 & 2079234 & 2408209 \\
\hline Indicador $\mathrm{Cc}$ & & & & & & & & \\
\hline ROE & & & & & 0,061 &, 060 & 058 & 0,053 \\
\hline ATPL & & & & & 23,576 & 23,837 & 24,603 & 24,588 \\
\hline ALDT & & & & & 0,265 & 0,250 & 0,274 & 0,282 \\
\hline CAOC & & & & & 0,009 & 0,006 & 0,006 & 0,006 \\
\hline NOPPL & & & & & 0,666 & 0,514 & 0,625 & 0,494 \\
\hline Indicac & & & & & & & & \\
\hline IRFX & & & & & 2,469 & 2,342 & 2,265 & 0,976 \\
\hline $\operatorname{IRTJ}(4$ & & & & & 1,236 & 2,215 & 1,357 & 0,999 \\
\hline IRCRE & & & & & 0,039 & 0,037 & 0,042 & 0,042 \\
\hline IRDT & & & & & 0,891 & 0,866 & 0,677 & 0,691 \\
\hline IRATPIB & & & & & 2,157 & 2,245 & 2,376 & 2,656 \\
\hline
\end{tabular}




\section{PAÍS SEM EXPERIÊNCIA DE CRISE}

17. Austrália - dez/98

Em milhões de dólares australianos

\begin{tabular}{|c|c|c|c|c|c|c|c|c|}
\hline Variáveis & ANO-8 & ANO-7 & ANO-6 & ANO-5 & ANO-4 & ANO-3 & ANO-2 & ANO-1 \\
\hline Patrimônio Líquido & 39300 & 43289 & 45221 & 46779 & 48803 & 50583 & 61310 & 64483 \\
\hline Ativo Total & 418322 & 433608 & 453971 & 461377 & 466089 & 510026 & 578069 & 644559 \\
\hline Passivo & 379022 & 390319 & 408750 & 414598 & 417286 & 459443 & 516759 & 580076 \\
\hline Ativos Líquidos & 69532 & 72263 & 79423 & 70594 & 67663 & 72709 & 80955 & 78932 \\
\hline Oper. de Créd. & 239051 & 249425 & 256501 & 271828 & 284599 & 298961 & 336345 & 380423 \\
\hline Créditos Anormais & 0,0142 & 0,0205 & 0,0191 & 0,0094 & 0,0050 & 0,0028 & 0,0017 & 0,0018 \\
\hline Depósitos Totais & 228711 & 232934 & 245237 & 260154 & 269323 & 285323 & 326443 & 366137 \\
\hline Expos. Câmbio & -29137 & -36858 & -39882 & -45512 & -33453 & -43530 & -51857 & -62563 \\
\hline PIB & 395300 & 399870 & 414750 & 435790 & 460350 & 484920 & 517180 & 545550 \\
\hline Taxa d & 12,98 & 8,85 & 5,67 & 4,71 & 6,30 & 7,50 & 6,60 & 5,00 \\
\hline Taxa & 1,84 & 1,88 & 2,00 & 2,03 & 1,88 & 2,00 & ,81 & 2,07 \\
\hline Variaça & & 0,022 & 0,064 & 0,015 & $-0,074$ & 0,064 & $-0,095$ & 0,144 \\
\hline Reserv & 1171010 & 1183680 & 842926 & 835920 & 800685 & 827940 & 1034960 & 1257460 \\
\hline Varia & & 0,011 & $-0,288$ & $-0,008$ & $-0,042$ & 0,034 & 0,250 & 0,215 \\
\hline INDPRESCAM & & 0,011 & 0,352 & 0,023 & $-0,032$ & 0,030 & $-0,345$ & $-0,071$ \\
\hline crédito & 255618 & 262093 & 273139 & 290232 & 320032 & 355318 & 388126 & 427280 \\
\hline crédito & 21434 & 24902 & 28405 & 30929 & 28457 & 28072 & 25635 & 19991 \\
\hline depósitos vista & 32335 & 34852 & 43929 & 53719 & 60496 & 64772 & 75801 & 86965 \\
\hline depósitos prazo & 172064 & 171102 & 177390 & 180265 & 197542 & 215949 & 236124 & 247668 \\
\hline Lucro-prejuízo & & & -413 & 2189 & 4350 & 4495 & 5849 & 5703 \\
\hline Ative & 14827 & 12413 & 14969 & 16281 & 17210 & 22562 & 27893 & 35887 \\
\hline Passi & 43964 & 49271 & 54850 & 61793 & 50663 & 66091 & 79750 & 98450 \\
\hline Ativo em TJ & 403495 & 421195 & 439003 & 445096 & 448879 & 487464 & 550176 & 608672 \\
\hline Passivo em TJ & 335058 & 341048 & 353900 & 352805 & 366623 & 393352 & 437009 & 481626 \\
\hline Expos. Taxa Jur & 68437 & 80147 & 85103 & 92291 & 82256 & 94113 & 113167 & 127046 \\
\hline Assis & 36263 & 36914 & 42222 & 35436 & 33052 & 32462 & 33935 & 32337 \\
\hline \multicolumn{9}{|l|}{ Indicador Contábil } \\
\hline ROE & & & & & 9 & & 95 & 88 \\
\hline $\mathrm{A}^{\prime}$ & & & & & & & & 9,996 \\
\hline ALDT & & & & & & & & 0,127 \\
\hline $\mathrm{CAC}$ & & & & & & & & 0,002 \\
\hline NOPPL & & & & & $-0,685$ & $-0,861$ & $-0,846$ & $-0,970$ \\
\hline \multicolumn{9}{|l|}{ Indicador de Riscos } \\
\hline $\operatorname{IRFX(4}$ & & & & & $-2,449$ & $-2,0$ & $-1,997$ & $-1,942$ \\
\hline $\operatorname{IRTJ}(4$ & & & & & 6,022 & 4,425 & 4,358 & 3,943 \\
\hline IRCRE $(4,99 \%$ & & & & & 0,088 & 0,086 & 0,038 & 0,018 \\
\hline IRDTAL & & & & & 0,938 & 0,842 & 1,259 & 1,883 \\
\hline IRATPIB & & & & & 1,075 & 1,157 & 1,329 & 1,471 \\
\hline
\end{tabular}

Fontes: OECD (2002); IMF (2003). 


\section{PAÍS SEM EXPERIÊNCIA DE CRISE}

18. Áustria - dez/98

Em milhões de schillings

\begin{tabular}{|c|c|c|c|c|c|c|c|c|}
\hline Variáveis & ANO-8 & ANO-7 & ANO-6 & ANO-5 & ANO-4 & ANO-3 & ANO-2 & ANO-1 \\
\hline Patrimônio Líquido & 186199 & 202114 & 220564 & 241649 & 263679 & 249820 & 245291 & 269237 \\
\hline Ativo Total & 4040476 & 4276192 & 4540452 & 4826676 & 5078727 & 5378672 & 5664416 & 5977085 \\
\hline Passivo & 3854277 & 4074078 & 4319888 & 4585027 & 4815048 & 5128852 & 5419125 & 5707848 \\
\hline Ativos Líquidos & 1776357 & 1803938 & 1864151 & 2063430 & 2204300 & 2473504 & 2608740 & 2728702 \\
\hline Oper. de Créd. & 2048063 & 2213849 & 2379219 & 2467115 & 2562296 & 2736711 & 2883060 & 3061696 \\
\hline Créditos Anormais & 0,0098 & 0,0100 & 0,0122 & 0,0102 & 0,0099 & 0,0085 & 0,0084 & 0,0074 \\
\hline Depósitos Totais & 2418374 & 2582012 & 2766671 & 2959631 & 3119992 & 3299841 & 3422372 & 3577859 \\
\hline Expos. Câmbio & -83122 & -88779 & -110964 & -121084 & -68860 & -70590 & -71700 & -144600 \\
\hline PIB & 1813480 & 1945820 & 2057270 & 2125340 & 2237940 & 2370720 & 2449960 & 2513480 \\
\hline Taxa de Juros & 8,53 & 9,10 & 9,35 & 7,22 & 5,03 & 4,36 & 3,19 & 3,27 \\
\hline Taxa de Câmbio & 15,19 & 15,29 & 15,61 & 16,68 & 16,01 & 15,00 & 15,75 & 17,05 \\
\hline Variação Câmbio & & 0,007 & 0,021 & 0,069 & $-0,040$ & $-0,063$ & 0,050 & 0,083 \\
\hline Reservas Intern. & 7304520 & 7924030 & 9703170 & 11288100 & 12165200 & 13020000 & 16277000 & 14903200 \\
\hline Variação Reservas & & 0,085 & 0,225 & 0,163 & 0,078 & 0,070 & 0,250 & $-0,084$ \\
\hline INDPRESCAM & & $-0,078$ & $-0,204$ & $-0,095$ & $-0,118$ & $-0,133$ & $-0,200$ & 0,167 \\
\hline \multicolumn{9}{|l|}{ Crédito privado } \\
\hline \multicolumn{9}{|l|}{ Crédito público } \\
\hline \multicolumn{9}{|l|}{ Depósitos vista } \\
\hline \multicolumn{9}{|l|}{ Depósitos prazo } \\
\hline Lucro-prejuízo & 13045 & 14495 & 12523 & 18308 & 18313 & 16108 & 18566 & 20527 \\
\hline Ativo em FX & 696124 & 704584 & 707490 & 758024 & 830804 & 854322 & 928500 & 980800 \\
\hline Passivo em FX & 779246 & 793363 & 818454 & 879108 & 899664 & 924912 & 1000200 & 1125400 \\
\hline Ativo em TJ & 3344352 & 3571608 & 3832962 & 4068652 & 4247923 & 4524350 & 4735916 & 4996285 \\
\hline Passivo em TJ & 3075031 & 3280715 & 3501434 & 3705919 & 3915384 & 4203940 & 4418925 & 4582448 \\
\hline Expos. Taxa Juros & 269321 & 290893 & 331528 & 362733 & 332539 & 320410 & 316991 & 413837 \\
\hline Assist. Financ. BC & 1282086 & 1316670 & 1359785 & 1418866 & 1473758 & 1578388 & 1698067 & 1799405 \\
\hline \multicolumn{9}{|l|}{ Indicador Contábil } \\
\hline $\mathrm{ROE}$ & & & & & 0,069 & 0,064 & 0,076 & 0,076 \\
\hline ATPL & & & & & 19,261 & 21,530 & 23,093 & 22,200 \\
\hline ALDT & & & & & 0,234 & 0,271 & 0,266 & 0,260 \\
\hline CAOC & & & & & 0,010 & 0,008 & 0,008 & 0,007 \\
\hline NOPPL & & & & & $-0,261$ & $-0,283$ & $-0,292$ & $-0,537$ \\
\hline \multicolumn{9}{|l|}{ Indicador de Riscos } \\
\hline $\operatorname{IRFX}(4,99 \%)$ & & & & & $-1,066$ & $-1,317$ & $-1,011$ & $-0,898$ \\
\hline $\operatorname{IRTJ}(4,99 \%)$ & & & & & 5,150 & 5,976 & 4,471 & 2,571 \\
\hline $\operatorname{IRCRE}(4,99 \%)$ & & & & & 0,022 & 0,034 & 0,023 & 0,023 \\
\hline IRDTAL & & & & & 0,645 & 0,512 & 0,450 & 0,420 \\
\hline IRATPIB & & & & & 2,583 & 2,573 & 2,611 & 2,687 \\
\hline
\end{tabular}

Fontes: OECD (1999); IMF (2003). 


\section{PAIIS SEM EXPERIÊNCIA DE CRISE}

19. Canadá - dez/98

Em milhões de dólares canadenses

\begin{tabular}{|c|c|c|c|c|c|c|c|c|}
\hline Variáveis & ANO-8 & ANO-7 & ANO-6 & ANO-5 & ANO-4 & ANO-3 & ANO-2 & ANO-1 \\
\hline Patrimônio Líquido & 27326 & 31066 & 31899 & 35352 & 38635 & 41600 & 43817 & 51183 \\
\hline Ativo Total & 483637 & 521727 & 576040 & 642841 & 723510 & 801432 & 901022 & 1087893 \\
\hline Passivo & 456311 & 490661 & 544141 & 607489 & 684875 & 759832 & 857205 & 1036710 \\
\hline Ativos Líquidos & 87747 & 108577 & 131824 & 158478 & 193362 & 237091 & 257814 & 284272 \\
\hline Oper. de Créd. & 375601 & 393693 & 421772 & 457155 & 501495 & 532732 & 607840 & 704624 \\
\hline Créditos Anormais & 0,0045 & 0,0069 & 0,0143 & 0,0105 & 0,0069 & 0,0048 & 0,0032 & 0,0028 \\
\hline Depósitos Totais & 363985 & 392075 & 418301 & 460504 & 497859 & 533098 & 559459 & 652753 \\
\hline Expos. Câmbio & -25280 & -30320 & -30240 & -30490 & -32000 & -14340 & -16440 & -36450 \\
\hline PIB & 667960 & 680950 & 705850 & 736300 & 786500 & 815240 & 851150 & 886360 \\
\hline Taxa de Juros & 12,90 & 8,97 & 6,64 & 4,63 & 5,05 & 6,92 & 4,33 & 3,26 \\
\hline Taxa de Câmbio & 1,65 & 1,65 & 1,75 & 1,82 & 2,05 & 2,03 & 1,97 & 1,93 \\
\hline Variação Câmbio & & 0,000 & 0,061 & 0,040 & 0,126 & $-0,010$ & $-0,030$ & $-0,020$ \\
\hline \multicolumn{9}{|l|}{ Reservas Intern. } \\
\hline \multicolumn{9}{|l|}{ Variação Reservas } \\
\hline \multicolumn{9}{|l|}{ INDPRESCAM } \\
\hline Crédito privado & 334550 & 348750 & 372220 & 415630 & 450770 & 474890 & 531940 & 607320 \\
\hline Crédito público & 29380 & 46130 & 59580 & 79260 & 91480 & 97210 & 94410 & 87350 \\
\hline Depósitos vista & 75920 & 79020 & 84730 & 91870 & 97840 & 109890 & 126600 & 139610 \\
\hline Depósitos prazo & 230300 & 241870 & 266810 & 301190 & 326970 & 342320 & 348690 & 377660 \\
\hline Lucro-prejuízo & 3608 & 3810 & 1953 & 3016 & 4387 & 5288 & 6456 & 7729 \\
\hline Ativo em FX & 57130 & 50810 & 57440 & 51740 & 73940 & 83180 & 97070 & 109860 \\
\hline Passivo em FX & 82410 & 81130 & 87680 & 82230 & 105940 & 97520 & 113510 & 146310 \\
\hline Ativo em TJ & 426507 & 470917 & 518600 & 591101 & 649570 & 718252 & 803952 & 978033 \\
\hline Passivo em TJ & 373901 & 409531 & 456461 & 525259 & 578935 & 662312 & 743695 & 890400 \\
\hline Expos. Taxa Juros & 52606 & 61386 & 62139 & 65842 & 70635 & 55940 & 60257 & 87633 \\
\hline Assist. Financ. BC & 60252 & 61008 & 81358 & 82201 & 97754 & 113787 & 125963 & 133566 \\
\hline \multicolumn{9}{|l|}{ Indicador Contábil } \\
\hline $\mathrm{ROE}$ & & & & & 0,114 & 0,127 & 0,147 & 0,151 \\
\hline ATPL & & & & & 18,727 & 19,265 & 20,563 & 21,255 \\
\hline ALDT & & & & & 0,192 & 0,231 & 0,236 & 0,231 \\
\hline CAOC & & & & & 0,007 & 0,005 & 0,003 & 0,003 \\
\hline NOPPL & & & & & $-0,828$ & $-0,345$ & $-0,375$ & $-0,712$ \\
\hline \multicolumn{9}{|l|}{ Indicador de Riscos } \\
\hline $\operatorname{IRFX}(4,99 \%)$ & & & & & $-3,227$ & $-0,772$ & $-0,874$ & $-2,231$ \\
\hline $\operatorname{IRTJ}(4,99 \%)$ & & & & & 7,123 & 3,011 & 3,204 & 5,365 \\
\hline $\operatorname{IRCRE}(4,99 \%)$ & & & & & 0,093 & 0,108 & 0,088 & 0,052 \\
\hline IRDTAL & & & & & 0,984 & 0,807 & 0,658 & 0,888 \\
\hline IRATPIB & & & & & 1,143 & 1,225 & 1,320 & 1,586 \\
\hline
\end{tabular}

Fontes: OECD (1988); IMF (2003). 
PAÍS SEM EXPERIÊNCIA DE CRISE

20. Dinamarca - dez/02

Variáveis

Patrimônio Líquido

Ativo Total

Passivo

Ativos Líquidos

Oper. de Créd.

Créditos Anormais

Depósitos Totais

Expos. Câmbio

PIB

Taxa de Juros

Taxa de Câmbio

Variação Câmbio

Reservas Intern.

Variação Reservas

INDPRESCAM

Crédito privado

Crédito público

Depósitos vista

Depósitos prazo

Lucro-prejuízo

Ativo em FX

Passivo em FX

Ativo em TJ

Passivo em TJ

Expos. Taxa Juros

Assist. Financ. BC

Indicador Contábil

ROE

ATPL

ALDT

CAOC

NOPPL

Indicador de Riscos

$\operatorname{IRFX}(4,99 \%)$

IRTJ(4,99\%)

IRCRE(4,99\%)

IRDTAL

IRATPIB

Fontes: OECD (2002); IMF (2003).

ANO-8

883472

469281

433769

126550

6,31

8,88
Em milhões de coroas dinamarquesas

ANO-7 ANO-6

$\begin{array}{llll}62246 & 70419 & 80197 & 84294\end{array}$

$\begin{array}{llll}945718 & 1016791 & 1163879 & 1288570\end{array}$

946372

$946372-1083682$

530067

440765

624674

493336

0,0160

0,0104

586094

650328

132090

104630

274200

289440

3,65

3,95

8,55

9,21

0,077

1204276

653209

576629

0,0071

722193

97520

298960

98960

$$
4,56
$$

8,99

$-0,024$

ANO-4 ANO-3

91931

$1457013-1574$

1574779

ANO-2

ANO-1

$-0,0452 \quad 0,038$

1365082

1479135

1745377

122083

727811

753397

1628536

1979421

609569

778770

609569

690388

0,0062

0,0077

0,0064

755061

850246

869861

1007131

37680

67800

14050

$-24980$

318820

339040

345620

352230

$3,64 \quad 5,46$

3,73

10,57

3,32

$10,15 \quad 10,45$

$0,129 \quad 0,030$

0,011

9,63

$-0,089$

$\begin{array}{rrrrrrrr}248310 & 287090 & 304470 & 321440 & 336340 & 346550 & 373200 & 391630 \\ 262200 & 296170 & 320020 & 325430 & 298270 & 258930 & 253060 & 265420 \\ -320 & 10767 & 10832 & 11542 & 11262 & 11074 & 14371 & 15101 \\ 309900 & 370890 & 448300 & 490190 & 506320 & 569520 & 508520 & 510300 \\ 183350 & 238800 & 343670 & 392670 & 468640 & 501720 & 494470 & 535280 \\ 635818 & 645901 & 715579 & 798380 & 950693 & 1005259 & 1236857 & 1469121 \\ 700122 & 707572 & 740012 & 811606 & 896442 & 977415 & 1134066 & 1322058 \\ -64304 & -61671 & -24433 & -13226 & 54251 & 27844 & 102791 & 147063 \\ 268693 & 283970 & 340744 & 373679 & 411938 & 427647 & 475919 & 571975\end{array}$

$\begin{array}{llll}0,123 & 0,116 & 0,123 & 0,124\end{array}$

$15,849 \quad 16,465 \quad 14,938 \quad 16,214$

$0,418 \quad 0,383 \quad 0,383 \quad 0,350$

$0,008 \quad 0,006 \quad 0,006 \quad 0,008$

$0,410 \quad 0,709 \quad 0,120 \quad-0,205$

$\begin{array}{llll}0,316 & 1,086 & 0,200 & -0,407\end{array}$

$0,456 \quad 0,446 \quad 1,463 \quad 2,397$

$\begin{array}{llll}0,054 & 0,026 & 0,009 & 0,012\end{array}$

$0,482 \quad 0,514 \quad 0,435 \quad 0,595$

$5,753 \quad 5,724 \quad 6,174 \quad 6,919$ 


\section{PAIIS SEM EXPERIÊNCIA DE CRISE}

21. Espanha - dez/98

Variáveis

Patrimônio Líquido

Ativo Total

Passivo

Ativos Líquidos

Oper. de Créd.

Créditos Anormais

Depósitos Totais

Expos. Câmbio

PIB

Taxa de Juros

Taxa de Câmbio

Variação Câmbio

Reservas Intern.

Variação Reservas

INDPRESCAM

Crédito privado

Crédito público

Depósitos vista

Depósitos prazo

Lucro-prejuízo

Ativo em FX

Passivo em FX

Ativo em TJ

Passivo em TJ

Expos. Taxa Juros

Assist. Financ. BC

Indicador Contábil

ROE

ATPL

ALDT

CAOC

NOPPL

Indicador de Riscos

$\operatorname{IRFX}(4,99 \%)$

IRTJ(4,99\%)

IRCRE(4,99\%)

IRDTAL

IRATPIB

Fontes: OECD (2002); IMF (2003).

Em bilhões de pesetas

ANO-8

$\begin{array}{llll}6451 & 8231 & 8428 & 9160\end{array}$

$70137 \quad 78868$

$63686 \quad 70637$

30224

31457

0,0121

45507

$-2669$

50145

14,76

137,87

31809

37341

0,0128

49593

$-2902$

54927

13,20

138,31

0,003
86910

78482

34407

40786

0,0147

52553

$-1629$

59105

13,01

157,61

0,140

103347

94187

41274

43125

0,0315

58086

4231

60953

12,33

195,34

0,239
ANO-4 ANO-3

10219

110692

100473

43343

48589

0,0174

63876

1262

64812

7,81

192,32

$-0,015$

10369

120221

109852

46292

52357

0,0110

70956

4421

72842

8,98

180,47

$-0,062$
ANO-2

$\begin{array}{rr}10857 & 11578 \\ 126276 & 134954 \\ 115419 & 123376 \\ 48558 & 51081 \\ 56615 & 63851 \\ 0,0107 & 0,0088 \\ 74982 & 79112 \\ 621 & -3832 \\ 77245 & 82218 \\ 7,65 & 5,49 \\ 188,77 & 204,68 \\ 0,046 & 0,084\end{array}$

$\begin{array}{rrrrrrrr}9595 & 10270 & 9584 & 9657 & 10159 & 10291 & 11144 & 13391 \\ 23000 & 26219 & 28416 & 32208 & 34492 & 37397 & 37579 & 35679 \\ 637 & 778 & 676 & 110 & 640 & 736 & 829 & 975 \\ 3800 & 4517 & 7868 & 16690 & 14565 & 17737 & 17057 & 16909 \\ 6468 & 7419 & 9497 & 12459 & 13303 & 13316 & 16436 & 20741 \\ 66337 & 74351 & 79042 & 86657 & 96127 & 102484 & 109219 & 118045 \\ 57218 & 63218 & 68985 & 81729 & 87170 & 96536 & 98984 & 102635 \\ 9119 & 11133 & 10057 & 4929 & 8957 & 5948 & 10236 & 15410 \\ 9153 & 11435 & 15856 & 23455 & 24034 & 26143 & 25351 & 25702 \\ & & & & & & & \\ 0,0987 & 0,0945 & 0,0802 & 0,012 & 0,063 & 0,071 & 0,076 & 0,084 \\ & & & & 10,832 & 11,594 & 11,631 & 11,656 \\ & & & & 0,302 & 0,284 & 0,310 & 0,321 \\ & & & & 0,017 & 0,011 & 0,011 & 0,009 \\ & & & & 0,123 & 0,426 & 0,057 & -0,331 \\ & & & & 0,649 & 2,280 & 0,264 & -0,932 \\ & & & & 4,609 & 3,068 & 4,347 & 3,749 \\ & & & & 0,082 & 0,091 & 0,103 & 0,042 \\ & & & & 0,659 & 0,790 & 0,652 & 0,516 \\ & & & & 2,163 & 2,040 & 1,900 & 1,892\end{array}$




\section{PAÍS SEM EXPERIÊNCIA DE CRISE}

22. Estados Unidos - dez/98

Variáveis

Patrimônio Líquido

Passivo

Ativos Líquidos

Oper. de Créd.

Créditos Anormais

Depósitos Totais

Expos. Câmbio

PIB

Taxa de Juros

Taxa de Câmbio

Variação Câmbio

Reservas Intern.

Variação Reservas

INDPRESCAM

Crédito privado

Crédito público

Depósitos vista

Depósitos prazo

Lucro-prejuízo

Ativo em FX

Passivo em FX

Ativo em TJ

Passivo em TJ

Expos. Taxa Juros

Assist. Financ. BC

Indicador Contábil

ROE

ATPL

ALDT

CAOC

NOPPL

Indicador de Riscos

$\operatorname{IRFX}(4,99 \%)$

$\operatorname{IRTJ}(4,99 \%)$

IRCRE(4,99\%)

IRDTAL

IRATPIB

Fontes: OECD (2002); IMF (2003).
Em milhões de dólares americanos ANO-8 ANO-7 ANO-6 \begin{tabular}{ccccc} 
ANO-5 & ANO-4 & ANO-3 & ANO-2 & ANO-1 \\
\hline 310918 & 348223 & 375127 & 414528 & 454242
\end{tabular} $\begin{array}{lllllllll}3417993 & 3492768 & 3691167 & 3988751 & 4289813 & 4551267 & 4971620 & 5379956\end{array}$ $\begin{array}{lllllllll}3187281 & 3230328 & 3395719 & 3677833 & 3941590 & 4176140 & 4557092 & 4925714\end{array}$ $\begin{array}{lllllllll}1057037 & 1143916 & 1222786 & 1213876 & 1221893 & 1259786 & 1360481 & 1444732\end{array}$ $\begin{array}{llllllll}2139569 & 2129905 & 2241078 & 2443073 & 2718622 & 2903505 & 3147302 & 3420545\end{array}$ $\begin{array}{llllllll}0,0163 & 0,0126 & 0,0075 & 0,0045 & 0,0046 & 0,0056 & 0,0061 & 0,0063\end{array}$ $\begin{array}{llllllll}2648422 & 2668472 & 2729726 & 2855174 & 3005031 & 3168912 & 3409584 & 3672687\end{array}$ $\begin{array}{lllllllll}-94960 & -78340 & -121840 & -177420 & -272400 & -271220 & -225500 & -230270\end{array}$ $\begin{array}{rrrrrrrr}5803200 & 5986200 & 6318900 & 6642300 & 7054300 & 7400500 & 7813200 & 8318400\end{array}$

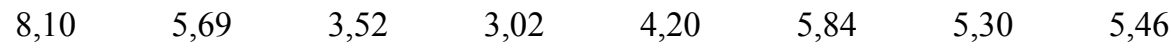

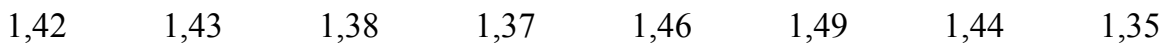
$\begin{array}{lllllll}0,007 & -0,035 & -0,007 & 0,066 & 0,021 & -0,034 & -0,062\end{array}$

$\begin{array}{rrrrrrrr}2494290 & 2545290 & 2623970 & 2754300 & 2940920 & 3223070 & 3422510 & 3750340 \\ 289490 & 335670 & 391890 & 421360 & 387990 & 372050 & 356060 & 366720 \\ 583950 & 621560 & 714320 & 788420 & 756740 & 710840 & 676270 & 656440 \\ 1307660 & 1386500 & 1389160 & 1377200 & 1376220 & 1490100 & 1613220 & 1761490 \\ & & & & & & & \\ 121000 & 147470 & 125400 & 78860 & 38860 & 34080 & 101960 & 150980 \\ 215960 & 225810 & 247240 & 256280 & 311260 & 305300 & 327460 & 381250 \\ 3296993 & 3345298 & 3565767 & 3909891 & 4250953 & 4517187 & 4869660 & 5228976 \\ 2971321 & 3004518 & 3148479 & 3421553 & 3630330 & 3870840 & 4229632 & 4544464 \\ 325672 & 340780 & 417288 & 488338 & 620623 & 646347 & 640028 & 684512 \\ 50077 & 47908 & 45525 & 39083 & 44138 & 56706 & 50956 & 54239 \\ & & & & & & & \\ & & & & 0,128 & 0,130 & 0,127 & 0,130 \\ & & & & 12,319 & 12,133 & 11,993 & 11,844 \\ & & & & 0,392 & 0,380 & 0,384 & 0,379 \\ & & & & 0,005 & 0,006 & 0,006 & 0,006 \\ & & & & -0,782 & -0,723 & -0,544 & -0,507 \\ & & & & -1,854 & -1,821 & -1,369 & -0,687 \\ & & & & 4,223 & 4,340 & 3,885 & 2,042 \\ & & & & 0,060 & 0,022 & 0,012 & 0,011 \\ & & & & 0,255 & 0,318 & 0,366 & 0,423 \\ & & & 0,708 & 0,716 & 0,744 & 0,763\end{array}$




\section{PAIIS SEM EXPERIÊNCIA DE CRISE}

23. Finlândia - dez/98

Variáveis*

Patrimônio Líquido
Ativo Total

Passivo

Ativos Líquidos

Oper. de Créd.

Créditos Anormais

Depósitos Totais

Expos. Câmbio

PIB

Taxa de Juros

Taxa de Câmbio

Variação Câmbio

Reservas Intern.

Variação Reservas

INDPRESCAM

Crédito privado

Crédito público

Depósitos vista

Depósitos prazo

Lucro-prejuízo

Ativo em FX

Passivo em FX

Ativo em TJ

Passivo em TJ

Expos. Taxa Juros

Assist. Financ. BC

Indicador Contábil

ROE

ATPL

ALDT

CAOC

NOPPL

Indicador de Riscos

$\operatorname{IRFX}(4,99 \%)$

$\operatorname{IRTJ}(4,99 \%)$

IRCRE(4,99\%)

IRDTAL

IRATPIB

* Dados trimestrais

Fontes: OECD (2002); IMF (2003).
Em milhões de marka

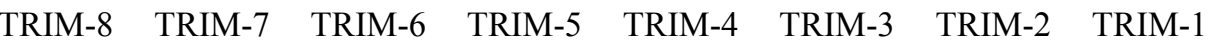

\begin{tabular}{|c|c|c|c|c|c|c|c|}
\hline 30977 & 32143 & 32810 & 34003 & 34581 & 34032 & 34812 & 34113 \\
\hline 424517 & 404694 & 411824 & 396715 & 390877 & 408809 & 414598 & 420638 \\
\hline 393540 & 372552 & 379014 & 362712 & 356296 & 374777 & 379786 & 386525 \\
\hline 55058 & 42221 & 43761 & 21711 & 14113 & 26450 & 17338 & 20774 \\
\hline 369459 & 362473 & 368063 & 375004 & 376764 & 382359 & 397260 & 399864 \\
\hline 0,0292 & 0,0258 & 0,0239 & 0,0198 & 0,0196 & 0,0165 & 0,0148 & 0,0110 \\
\hline 297267 & 300386 & 297359 & 303711 & 302878 & 307189 & 307645 & 315174 \\
\hline-2631 & 14995 & 25912 & 18688 & 11959 & 20776 & 16856 & 9444 \\
\hline 149940 & 157630 & 157830 & 170130 & 165800 & 172010 & 169580 & 182140 \\
\hline 3,07 & 3,08 & 3,17 & 3,61 & 3,46 & 3,70 & 3,61 & 3,51 \\
\hline \multirow[t]{2}{*}{6,93} & 7,20 & 7,24 & 7,31 & 7,49 & 7,31 & 6,99 & 7,18 \\
\hline & 0,039 & 0,006 & 0,010 & 0,025 & $-0,024$ & $-0,044$ & 0,027 \\
\hline \multirow[t]{3}{*}{55058} & 42221 & 43761 & 21711 & 14113 & 26450 & 17338 & 20774 \\
\hline & $-0,233$ & 0,036 & $-0,504$ & $-0,350$ & 0,874 & $-0,345$ & 0,198 \\
\hline & 0,272 & $-0,031$ & 0,514 & 0,375 & $-0,898$ & 0,301 & $-0,171$ \\
\hline 334782 & 335370 & 338195 & 337266 & 340284 & 348942 & 356945 & 358797 \\
\hline 34677 & 27103 & 29868 & 37738 & 36480 & 33417 & 40315 & 41067 \\
\hline 192368 & 195478 & 192830 & 201557 & 201435 & 204501 & 204709 & 211632 \\
\hline 104899 & 104908 & 104529 & 102154 & 101443 & 102688 & 102936 & 103542 \\
\hline 2640 & & & 5597 & & & & 8746 \\
\hline 99964 & 110406 & 130334 & 115806 & 107411 & 106311 & 108819 & 111320 \\
\hline 102595 & 95411 & 104422 & 97118 & 95452 & 85535 & 91963 & 101876 \\
\hline 324553 & 294288 & 281490 & 280909 & 283466 & 302498 & 305779 & 309318 \\
\hline 290945 & 277140 & 274592 & 265594 & 260844 & 289242 & 287823 & 284649 \\
\hline 33608 & 17148 & 6898 & 15315 & 22622 & 13256 & 17956 & 24669 \\
\hline \multirow[t]{11}{*}{46179} & 37930 & 39935 & 30405 & 23351 & 36256 & 24596 & 17970 \\
\hline & & & & 0,000 & 0,085 & 0,165 & 0,256 \\
\hline & & & & 11,303 & 12,013 & 11,910 & 12,331 \\
\hline & & & & $-0,031$ & $-0,032$ & $-0,024$ & 0,009 \\
\hline & & & & 0,020 & 0,017 & 0,015 & 0,011 \\
\hline & & & & 0,346 & 0,610 & 0,484 & 0,277 \\
\hline & & & & 0,168 & 0,276 & 0,080 & 0,045 \\
\hline & & & & 0,319 & 0,176 & 0,085 & 0,118 \\
\hline & & & & 0,067 & 0,069 & 0,056 & 0,085 \\
\hline & & & & $-0,624$ & $-0,838$ & $-0,670$ & 3,676 \\
\hline & & & & 2,469 & 2,493 & 2,574 & 2,452 \\
\hline
\end{tabular}




\section{PAÍS SEM EXPERIÊNCIA DE CRISE}

24. França - dez/98

Em milhões de francos franceses

\begin{tabular}{|c|c|c|c|c|c|c|c|c|}
\hline Variáveis & ANO-8 & ANO-7 & ANO-6 & ANO-5 & ANO-4 & ANO-3 & ANO-2 & ANO-1 \\
\hline Patrimônio Líquido & 508976 & 595549 & 655102 & 748312 & 774819 & 785523 & 773791 & 806959 \\
\hline Ativo Total & 15069719 & 15501548 & 16281038 & 16664311 & 16920699 & 17759588 & 18778536 & 20193498 \\
\hline Passivo & 14560743 & 14905999 & 15625936 & 15915999 & 16145880 & 16974065 & 18004745 & 19386539 \\
\hline Ativos Líquidos & 7399459 & 7787837 & 8247694 & 9046394 & 9278499 & 9852394 & 10848091 & 11597710 \\
\hline Oper. de Créd. & 6063585 & 6374522 & 6605304 & 6677026 & 6681385 & 6839377 & 6812684 & 7263672 \\
\hline Créditos Anormais & 0,0062 & 0,0071 & 0,0123 & 0,0178 & 0,0151 & 0,0159 & 0,0115 & 0,0087 \\
\hline Depósitos Totais & 6337475 & 6964925 & 7628084 & 8259669 & 8363028 & 8783093 & 8801033 & 9490699 \\
\hline Expos. Câmbio & -328400 & -343700 & -75600 & 343800 & 38900 & 208800 & 64400 & 252800 \\
\hline PIB & 6621800 & 6895300 & 7119200 & 7227200 & 7488200 & 7759900 & 7955200 & 8206900 \\
\hline Taxa de Juros & 9,85 & 9,49 & 10,35 & 8,75 & 5,69 & 6,35 & 3,73 & 3,24 \\
\hline Taxa de Câmbio & 7,30 & 7,41 & 7,57 & 8,10 & 7,80 & 7,28 & 7,53 & 8,08 \\
\hline Variação Câmbio & & 0,015 & 0,022 & 0,070 & $-0,037$ & $-0,067$ & 0,034 & 0,073 \\
\hline \multicolumn{9}{|l|}{ Reservas Intern. } \\
\hline \multicolumn{9}{|l|}{ Variação Reservas } \\
\hline \multicolumn{9}{|l|}{ INDPRESCAM } \\
\hline Crédito privado & 6358200 & 6660800 & 6929900 & 6712300 & 6588700 & 6745200 & 6653000 & 6784900 \\
\hline Crédito público & 681300 & 630200 & 698500 & 798400 & 1074200 & 1275100 & 1565600 & 1728800 \\
\hline Depósitos vista & 1430100 & 1350900 & 1348900 & 1364300 & 1414800 & 1557200 & 1553600 & 1669700 \\
\hline Depósitos prazo & 2518500 & 2564600 & 2618800 & 2776100 & 3012300 & 3373600 & 3581700 & 3854700 \\
\hline \multicolumn{9}{|l|}{ Lucro-prejuízo } \\
\hline Ativo em FX & 2337700 & 2367800 & 2822000 & 3427600 & 3207100 & 3454900 & 3582400 & 4412000 \\
\hline Passivo em FX & 2666100 & 2711500 & 2897600 & 3083800 & 3168200 & 3246100 & 3518000 & 4159200 \\
\hline Ativo em TJ & 12732019 & 13133748 & 13459038 & 13236711 & 13713599 & 14304688 & 15196136 & 15781498 \\
\hline Passivo em TJ & 11894643 & 12194499 & 12728336 & 12832199 & 12977680 & 13727965 & 14486745 & 15227339 \\
\hline Expos. Taxa Juros & 837376 & 939249 & 730702 & 404512 & 735919 & 576723 & 709391 & 554159 \\
\hline Assist. Financ. BC & 6525201 & 6422827 & 6295304 & 6496025 & 6658076 & 6864400 & 7506840 & 7872720 \\
\hline \multicolumn{9}{|l|}{ Indicador Contábil } \\
\hline ROE & & & & & $-0,013$ & 0,013 & 0,024 & 0,053 \\
\hline ATPL & & & & & 21,838 & 22,609 & 24,268 & 25,024 \\
\hline ALDT & & & & & 0,313 & 0,340 & 0,380 & 0,392 \\
\hline CAOC & & & & & 0,015 & 0,016 & 0,012 & 0,009 \\
\hline NOPPL & & & & & 0,050 & 0,266 & 0,083 & 0,313 \\
\hline \multicolumn{9}{|l|}{ Indicador de Riscos } \\
\hline $\operatorname{IRFX}(4,99 \%)$ & & & & & 0,208 & 1,182 & 0,351 & 0,909 \\
\hline $\operatorname{IRTJ}(4,99 \%)$ & & & & & 3,942 & 3,264 & 3,863 & 1,993 \\
\hline $\operatorname{IRCRE}(4,99 \%)$ & & & & & 0,080 & 0,040 & 0,047 & 0,061 \\
\hline IRDTAL & & & & & 0,498 & 0,322 & 0,170 & 0,253 \\
\hline IRATPIB & & & & & 2,426 & 2,452 & 2,603 & 2,807 \\
\hline
\end{tabular}

Fontes: OECD (2002); IMF (2003). 


\section{PAÍS SEM EXPERIÊNCIA DE CRISE}

25. Holanda - dez/98

Variáveis

Patrimônio Líquido

Passivo

Ativos Líquidos

Oper. de Créd.

Créditos Anormais

Depósitos Totais

Expos. Câmbio

PIB

Taxa de Juros

Taxa de Câmbio

Variação Câmbio

Reservas Intern.

Variação Reservas

INDPRESCAM

Crédito privado

Crédito público

Depósitos vista

Depósitos prazo

Lucro-prejuízo

Ativo em FX

Passivo em FX

Ativo em TJ

Passivo em TJ

Expos. Taxa Juros

Assist. Financ. BC

Indicador Contábil

ROE

ATPL

ALDT

CAOC

NOPPL

Indicador de Riscos

$\operatorname{IRFX}(4,99 \%)$

$\operatorname{IRTJ}(4,99 \%)$

IRCRE $(4,99 \%)$

IRDTAL

IRATPIB

Fontes: OECD (1999); IMF (2003).

ANO-8

Em milhões de guilders

$\begin{array}{rrrrrrrr}45047 & 47634 & 50459 & 56031 & 59681 & 64039 & 71526 & 93151 \\ 1122490 & 1167660 & 1255536 & 1363907 & 1401994 & 1538948 & 1745915 & 2171788 \\ 1077443 & 1120026 & 1205077 & 1307876 & 1342313 & 1474909 & 1674389 & 2078637 \\ 406883 & 404018 & 434760 & 474769 & 483777 & 522796 & 584040 & 763993 \\ 685356 & 731174 & 789757 & 856348 & 883475 & 976245 & 1117256 & 1355185 \\ 0,0035 & 0,0046 & 0,0042 & 0,0036 & 0,0027 & 0,0024 & 0,0026 & 0,0027 \\ 685356 & 731174 & 789757 & 856348 & 883475 & 976245 & 1117256 & 1355185 \\ 54910 & 54190 & 45460 & 51530 & 23250 & 21150 & -12240 & -54850 \\ 537870 & 564950 & 589430 & 605440 & 639600 & 666040 & 694300 & 734850 \\ 8,29 & 9,01 & 9,27 & 7,10 & 5,14 & 4,22 & 2,89 & 3,07 \\ 2,40 & 2,45 & 2,49 & 2,67 & 2,53 & 2,38 & 2,51 & 2,72 \\ & 0,021 & 0,016 & 0,072 & -0,052 & -0,059 & 0,055 & 0,084\end{array}$

$\begin{array}{rrrrrrrr}86630 & 92000 & 98000 & 111920 & 114040 & 134710 & 155580 & 170490 \\ 310490 & 325650 & 342320 & 355150 & 353920 & 363230 & 372140 & 395160 \\ 4100 & 4396 & 5005 & 6222 & 6828 & 7602 & 9214 & 10395 \\ 314210 & 323350 & 345750 & 379940 & 347670 & 375660 & 416240 & 531720 \\ 259300 & 269160 & 300290 & 328410 & 324420 & 354510 & 428480 & 586570 \\ 808280 & 844310 & 909786 & 983967 & 1054324 & 1163288 & 1329675 & 1640068 \\ 818143 & 850866 & 904787 & 979466 & 1017893 & 1120399 & 1245909 & 1492067 \\ -9863 & -6556 & 4999 & 4501 & 36431 & 42889 & 83766 & 148001 \\ 274642 & 288390 & 303612 & 333261 & 331978 & 358201 & 422361 & 558232\end{array}$

$\begin{array}{llll}0,114 & 0,119 & 0,129 & 0,112\end{array}$

$23,491 \quad 24,031 \quad 24,410 \quad 23,315$

$0,172 \quad 0,169 \quad 0,145 \quad 0,152$

$\begin{array}{llll}0,003 & 0,002 & 0,003 & 0,003\end{array}$

$0,390 \quad 0,330 \quad 0,171 \quad 0,589$

$1,531 \quad 1,523 \quad-0,616 \quad-1,175$

$2,399 \quad 3,088 \quad 4,217 \quad 3,169$

$0,023 \quad 0,025 \quad 0,017 \quad 0,004$

$0,910 \quad 0,948 \quad 1,469 \quad 2,013$

$\begin{array}{llll}2,528 & 2,665 & 3,017 & 3,878\end{array}$ 
PAÍS SEM EXPERIÊNCIA DE CRISE

26. Islândia - dez/98

Em milhões de coroas islandês

\begin{tabular}{|c|c|c|c|c|c|c|c|c|}
\hline Variáveis & ANO-8 & ANO-7 & ANO-6 & ANO-5 & ANO-4 & ANO-3 & ANO-2 & ANO-1 \\
\hline Patrimônio Líquido & 16163 & 19536 & 16718 & 19025 & 19885 & 20982 & 24157 & 26458 \\
\hline Ativo Total & 213368 & 237501 & 245065 & 256861 & 251391 & 263258 & 302735 & 360486 \\
\hline Passivo & 197205 & 217965 & 228347 & 237836 & 231506 & 242276 & 278578 & 334028 \\
\hline Ativos Líquidos & 44049 & 47681 & 48714 & 54378 & 46707 & 52321 & 68628 & 100399 \\
\hline Oper. de Créd. & 158736 & 178640 & 185216 & 191021 & 194164 & 197695 & 219624 & 246502 \\
\hline Créditos Anormais & 0,0163 & 0,0142 & 0,0367 & 0,0317 & 0,0243 & 0,0148 & 0,0135 & 0,0099 \\
\hline Depósitos Totais & 142098 & 161990 & 168664 & 180437 & 183009 & 187893 & 206428 & 233951 \\
\hline Expos. Câmbio & -34584 & -35111 & -39092 & -36292 & -23592 & -22143 & -35456 & -52139 \\
\hline PIB & 370925 & 401372 & 401025 & 413331 & 439108 & 452139 & 485192 & 512679 \\
\hline Taxa de Juros & 9,50 & 15,00 & 9,90 & 6,57 & 4,87 & 6,53 & 7,56 & 7,14 \\
\hline Taxa de Câmbio & 78,80 & 79,56 & 87,89 & 99,90 & 99,71 & 96,96 & 96,19 & 97,39 \\
\hline Variação Câmbio & & 0,010 & 0,105 & 0,137 & $-0,002$ & $-0,028$ & $-0,008$ & 0,012 \\
\hline \multicolumn{9}{|l|}{ Reservas Intern. } \\
\hline \multicolumn{9}{|l|}{ Variação Reservas } \\
\hline \multicolumn{9}{|l|}{ INDPRESCAM } \\
\hline Crédito privado & 157123 & 175155 & 187675 & 193643 & 196262 & 208982 & 236720 & 348883 \\
\hline Crédito público & 18416 & 18848 & 20577 & 26746 & 19168 & 11432 & 13241 & 10578 \\
\hline Depósitos vista & 21587 & 26317 & 26351 & 27663 & 30313 & 33146 & 36081 & 42600 \\
\hline Depósitos prazo & 103258 & 118696 & 124088 & 132526 & 132482 & 133341 & 140725 & 150977 \\
\hline \multicolumn{9}{|l|}{ Lucro-prejuízo } \\
\hline Ativo em FX & 4488 & 4644 & 4524 & 6835 & 8105 & 5213 & 7285 & 11076 \\
\hline Passivo em FX & 39072 & 39755 & 43616 & 43127 & 31697 & 27356 & 42741 & 63215 \\
\hline Ativo em TJ & 208880 & 232857 & 240541 & 250026 & 243286 & 258045 & 295450 & 349410 \\
\hline Passivo em TJ & 158133 & 178210 & 184731 & 194709 & 199809 & 214920 & 235837 & 270813 \\
\hline Expos. Taxa Juros & 50747 & 54647 & 55810 & 55317 & 43477 & 43125 & 59613 & 78597 \\
\hline Assist. Financ. BC & 5817 & 5853 & 4924 & 3411 & 5254 & 12918 & 13259 & 22868 \\
\hline \multicolumn{9}{|l|}{ Indicador Contábil } \\
\hline ROE & & & & & 0,038 & 0,060 & 0,084 & 0,110 \\
\hline ATPL & & & & & 12,642 & 12,547 & 12,532 & 13,625 \\
\hline ALDT & & & & & 0,227 & 0,210 & 0,268 & 0,331 \\
\hline $\mathrm{CAOC}$ & & & & & 0,024 & 0,015 & 0,013 & 0,010 \\
\hline NOPPL & & & & & $-1,186$ & $-1,055$ & $-1,468$ & $-1,971$ \\
\hline \multicolumn{9}{|l|}{ Indicador de Riscos } \\
\hline $\operatorname{IRFX}(4,99 \%)$ & & & & & $-10,650$ & $-4,585$ & $-3,324$ & $-4,702$ \\
\hline $\operatorname{IRTJ}(4,99 \%)$ & & & & & 19,627 & 8,929 & 5,588 & 7,088 \\
\hline $\operatorname{IRCRE}(4,99 \%)$ & & & & & 0,193 & 0,181 & 0,157 & 0,116 \\
\hline IRDTAL & & & & & 0,482 & 0,418 & 0,428 & 0,601 \\
\hline IRATPIB & & & & & 0,611 & 0,617 & 0,721 & 0,897 \\
\hline
\end{tabular}

Fontes: OECD (2002); IMF (2003). 


\section{PAIIS SEM EXPERIÊNCIA DE CRISE}

27. Itália - dez/98

\begin{tabular}{|c|c|c|c|c|c|c|c|c|}
\hline Variáveis & ANO-8 & ANO-7 & ANO-6 & ANO-5 & ANO-4 & ANO-3 & ANO-2 & ANO-1 \\
\hline Patrimônio Líquido & 92686 & 122069 & 147918 & 155355 & 165646 & 164302 & 168848 & 174789 \\
\hline Ativo Total & 1699027 & 1938112 & 2254107 & 2412247 & 2464892 & 2529985 & 2680633 & 2810581 \\
\hline Passivo & 1606341 & 1816043 & 2106189 & 2256892 & 2299246 & 2365683 & 2511785 & 2635792 \\
\hline Ativos Líquidos & 445143 & 504273 & 616959 & 629388 & 643448 & 582632 & 642675 & 614419 \\
\hline Oper. de Créd. & 775334 & 885151 & 988281 & 1028446 & 1039247 & 1073005 & 1077372 & 1157992 \\
\hline Créditos Anormais & 0,0129 & 0,0106 & 0,0131 & 0,0170 & 0,0182 & 0,0175 & 0,0160 & 0,0164 \\
\hline Depósitos Totais & 887135 & 972452 & 1017627 & 1113228 & 1139420 & 1151008 & 1225889 & 1257866 \\
\hline Expos. Câmbio & -116010 & -154880 & -202310 & -140920 & -173700 & -112460 & -68350 & -81100 \\
\hline PIB & 1320830 & 1440650 & 1517600 & 1563270 & 1653400 & 1787280 & 1902280 & 1987160 \\
\hline Taxa de Juros & 12,38 & 12,21 & 14,02 & 10,20 & 8,51 & 10,46 & 8,82 & 6,88 \\
\hline Taxa de Câmbio & 1607,82 & 1646,51 & 2022,43 & 2340,51 & 2379,18 & 2355,67 & 2200,90 & 2373,59 \\
\hline Variação Câmbio & & 0,024 & 0,228 & 0,157 & 0,017 & $-0,010$ & $-0,066$ & 0,078 \\
\hline \multicolumn{9}{|l|}{ Reservas Intern. } \\
\hline \multicolumn{9}{|l|}{ Variação Reservas } \\
\hline \multicolumn{9}{|l|}{ INDPRESCAM } \\
\hline \multicolumn{9}{|l|}{ Crédito privado } \\
\hline \multicolumn{9}{|l|}{ Crédito público } \\
\hline Depósitos vista & 385620 & 430800 & 426200 & 454920 & 471380 & 471060 & 498870 & 531720 \\
\hline Depósitos prazo & 363970 & 389560 & 430860 & 469880 & 458910 & 476500 & 469390 & 359510 \\
\hline Lucro-prejuízo & 8967 & 8790 & 6750 & 5561 & 1188 & 631 & 4528 & 1149 \\
\hline Ativo em FX & 116100 & 124900 & 165190 & 229060 & 201960 & 231120 & 295730 & 311640 \\
\hline Passivo em FX & 232110 & 279780 & 367500 & 369980 & 375660 & 343580 & 364080 & 392740 \\
\hline Ativo em TJ & 1582927 & 1813212 & 2088917 & 2183187 & 2262932 & 2298865 & 2384903 & 2498941 \\
\hline Passivo em TJ & 1374231 & 1536263 & 1738689 & 1886912 & 1923586 & 2022103 & 2147705 & 2243052 \\
\hline Expos. Taxa Juros & 208696 & 276949 & 350228 & 296275 & 339346 & 276762 & 237198 & 255889 \\
\hline Assist. Financ. BC & 112970 & 112079 & 168167 & 181808 & 169478 & 174018 & 192552 & 201942 \\
\hline \multicolumn{9}{|l|}{ Indicador Contábil } \\
\hline ROE & & & & & 0,007 & 0,004 & 0,027 & 0,007 \\
\hline ATPL & & & & & 14,880 & 15,398 & 15,876 & 16,080 \\
\hline ALDT & & & & & 0,416 & 0,355 & 0,367 & 0,328 \\
\hline CAOC & & & & & 0,018 & 0,017 & 0,016 & 0,016 \\
\hline NOPPL & & & & & $-1,049$ & $-0,684$ & $-0,405$ & $-0,464$ \\
\hline \multicolumn{9}{|l|}{ Indicador de Riscos } \\
\hline $\operatorname{IRFX}(4,99 \%)$ & & & & & $-5,203$ & $-3,321$ & $-0,836$ & $-1,338$ \\
\hline $\operatorname{IRTJ}(4,99 \%)$ & & & & & 10,165 & 8,172 & 2,900 & 4,221 \\
\hline $\operatorname{IRCRE}(4,99 \%)$ & & & & & 0,045 & 0,030 & 0,012 & 0,014 \\
\hline IRDTAL & & & & & 0,335 & 0,299 & 0,217 & 0,281 \\
\hline IRATPIB & & & & & 1,780 & 1,549 & 1,532 & 1,572 \\
\hline
\end{tabular}

Em bilhões de liras italianas 


\section{PAIIS SEM EXPERIÊNCIA DE CRISE}

28. Nova Zelândia - dez/98

Em milhões de dólares neozelandeses

Variáveis

Patrimônio Líquido ANO-8

Ativo Total

Passivo

Ativos Líquidos

Oper. de Créd.

Créditos Anormais

Depósitos Totais

Expos. Câmbio

PIB

Taxa de Juros

Taxa de Câmbio

Variação Câmbio

Reservas Intern.

Variação Reservas

INDPRESCAM

Crédito privado

Crédito público

Depósitos vista

Depósitos prazo

Lucro-prejuízo

Ativo em FX

Passivo em FX

Ativo em TJ

Passivo em TJ

Expos. Taxa Juros

Assist. Financ. BC

Indicador Contábil

ROE

ATPL

ALDT

CAOC

NOPPL

Indicador de Riscos

$\operatorname{IRFX}(4,99 \%)$

$\operatorname{IRTJ}(4,99 \%)$

IRCRE(4,99\%)

IRDTAL

IRATPIB

Fontes: OECD (1999); IMF (2003).
ANO-4 ANO-3 ANO-2 ANO-1

$\begin{array}{rrrrrrrr}4870 & 4606 & 3571 & 4093 & 4420 & 4887 & 4364 & 6289 \\ 78005 & 80353 & 83279 & 85293 & 91984 & 103292 & 118601 & 130164 \\ 73135 & 75747 & 79708 & 81200 & 87564 & 98405 & 114237 & 123875 \\ 24909 & 25811 & 25604 & 23038 & 18951 & 19434 & 18505 & 18889 \\ 49376 & 50001 & 54730 & 59393 & 68898 & 79793 & 89660 & 98916 \\ 0,0080 & 0,0104 & 0,0096 & 0,0009 & -0,0014 & -0,0001 & -0,0005 & 0,0009 \\ 71171 & 73752 & 77514 & 78997 & 84183 & 94017 & 93915 & 100641 \\ -9769 & -10423 & -14870 & -14478 & -16747 & -19108 & -19328 & -25975 \\ 73151 & 72938 & 75246 & 81388 & 87051 & 92679 & 96910 & 99982 \\ 13,42 & 9,94 & 6,63 & 6,25 & 6,13 & 8,91 & 9,38 & 7,38 \\ 2,42 & 2,64 & 2,67 & 2,46 & 2,27 & 2,28 & 2,04 & 2,32 \\ & 0,091 & 0,011 & -0,079 & -0,077 & 0,004 & -0,105 & 0,137\end{array}$

$\begin{array}{rrrrrrrr}8448 & 8530 & 8538 & 9287 & 9591 & 10047 & 9531 & 10119 \\ 46811 & 47030 & 48430 & 51715 & 55986 & 61667 & 74020 & 77726 \\ 406 & 315 & 313 & 701 & 839 & 1015 & 1016 & 1118 \\ 3099 & 2411 & 2314 & 2074 & 2427 & 2993 & 5031 & 3292 \\ 12868 & 12834 & 17184 & 16552 & 19174 & 22101 & 24359 & 29267 \\ 74906 & 77942 & 80965 & 83219 & 89557 & 100299 & 113570 & 126872 \\ 60268 & 62913 & 62524 & 64648 & 68390 & 76304 & 89878 & 94609 \\ 14639 & 15029 & 18441 & 18571 & 21167 & 23995 & 23692 & 32264\end{array}$

$\begin{array}{rrrr}0,190 & 0,208 & 0,233 & 0,178 \\ 20,811 & 21,136 & 27,177 & 20,697 \\ 0,225 & 0,207 & 0,197 & 0,188 \\ -0,001 & 0,000 & 0,000 & 0,001 \\ -3,789 & -3,910 & -4,429 & -4,130 \\ & & & \\ -14,438 & -10,551 & -15,451 & -12,240 \\ 18,248 & 13,250 & 18,940 & 15,204 \\ 0,189 & 0,164 & 0,039 & 0,030 \\ 0,460 & 0,775 & 0,813 & 0,724 \\ 1,171 & 1,311 & 1,527 & 1,641\end{array}$




\section{PAIIS SEM EXPERIÊNCIA DE CRISE}

29. Noruega - dez/02

Em milhões de coroas norueguesas

\begin{tabular}{|c|c|c|c|c|c|c|c|c|}
\hline Variáveis & ANO-8 & ANO-7 & ANO-6 & ANO-5 & ANO-4 & ANO-3 & ANO-2 & ANO-1 \\
\hline Patrimônio Líquido & 45089 & 51675 & 58594 & 65196 & 72988 & 83903 & 93690 & 98116 \\
\hline Ativo Total & 695179 & 708356 & 843219 & 952103 & 1056538 & 1175187 & 1334522 & 1451435 \\
\hline Passivo & 650090 & 656681 & 784625 & 886907 & 983550 & 1091284 & 1240832 & 1353319 \\
\hline Ativos Líquidos & 123219 & 124436 & 174689 & 165242 & 174330 & 186929 & 208672 & 217445 \\
\hline Oper. de Créd. & 540180 & 552986 & 632189 & 750049 & 839673 & 923055 & 1054490 & 1160342 \\
\hline Créditos Anormais & 0,0021 & 0,0014 & 0,0016 & 0,0002 & 0,0013 & 0,0007 & 0,0006 & 0,0037 \\
\hline Depósitos Totais & 567721 & 557574 & 613375 & 662568 & 743977 & 812958 & 919251 & 1023865 \\
\hline Expos. Câmbio & -13350 & -13550 & -69560 & -115850 & -133190 & -155970 & -192380 & -222280 \\
\hline PIB & 233970 & 246810 & 276310 & 296430 & 296330 & 345770 & 397310 & 386710 \\
\hline Taxa de Juros & 6,34 & 5,58 & 4,55 & 3,94 & 8,57 & 6,03 & 7,51 & 7,15 \\
\hline Taxa de Câmbio & 9,87 & 9,39 & 9,26 & 9,87 & 10,70 & 11,03 & 11,53 & 11,33 \\
\hline Variação Câmbio & & $-0,049$ & $-0,014$ & 0,066 & 0,084 & 0,031 & 0,045 & $-0,017$ \\
\hline \multicolumn{9}{|l|}{ Reservas Intern. } \\
\hline \multicolumn{9}{|l|}{ Variação Reservas } \\
\hline \multicolumn{9}{|l|}{ INDPRESCAM } \\
\hline Crédito privado & 479680 & 527460 & 599820 & 708010 & 801580 & 849700 & 969640 & 1075450 \\
\hline Crédito público & 94420 & 89140 & 101690 & 85690 & 125960 & 74010 & 64560 & 33950 \\
\hline Depósitos vista & 314800 & 316290 & 349700 & 371960 & 453200 & 479340 & 521010 & 616020 \\
\hline Depósitos prazo & 149240 & 164570 & 166710 & 150520 & 157800 & 141030 & 159080 & 128060 \\
\hline Lucro-prejuízo & 7674 & 8885 & 8875 & 8415 & 7907 & 11549 & 13430 & 10976 \\
\hline Ativo em FX & 49140 & 47220 & 58550 & 71560 & 93670 & 99840 & 135210 & 136010 \\
\hline Passivo em FX & 62490 & 60770 & 128110 & 187410 & 226860 & 255810 & 327590 & 358290 \\
\hline Ativo em TJ & 646039 & 661136 & 784669 & 880543 & 962868 & 1075347 & 1199312 & 1315425 \\
\hline Passivo em TJ & 587600 & 595911 & 656515 & 699497 & 756690 & 835474 & 913242 & 995029 \\
\hline Expos. Taxa Juros & 58439 & 65225 & 128154 & 181046 & 206178 & 239873 & 286070 & 320396 \\
\hline Assist. Financ. BC & 43144 & 48914 & 98724 & 134991 & 132888 & 151615 & 165550 & 166766 \\
\hline \multicolumn{9}{|l|}{ Indicador Contábil } \\
\hline $\mathrm{ROE}$ & 0,1702 & 0,1719 & 0,1515 & 0,129 & 0,108 & 0,138 & 0,143 & 0,112 \\
\hline ATPL & & & & & 14,476 & 14,006 & 14,244 & 14,793 \\
\hline ALDT & & & & & 0,056 & 0,043 & 0,047 & 0,049 \\
\hline CAOC & & & & & 0,001 & 0,001 & 0,001 & 0,004 \\
\hline NOPPL & & & & & $-1,825$ & $-1,859$ & $-2,053$ & $-2,265$ \\
\hline \multicolumn{9}{|l|}{ Indicador de Riscos } \\
\hline $\operatorname{IRFX}(4,99 \%)$ & & & & & $-7,659$ & $-7,817$ & $-8,338$ & $-4,904$ \\
\hline $\operatorname{IRTJ}(4,99 \%)$ & & & & & 11,856 & 12,022 & 12,398 & 7,068 \\
\hline $\operatorname{IRCRE}(4,99 \%)$ & & & & & 0,015 & 0,014 & 0,010 & 0,035 \\
\hline IRDTAL & & & & & 3,849 & 5,039 & 5,089 & 4,884 \\
\hline IRATPIB & & & & & 4,581 & 4,228 & 4,193 & 4,660 \\
\hline
\end{tabular}

Fontes: OECD (2002); IMF (2003). 


\section{PAÍS SEM EXPERIÊNCIA DE CRISE}

30. Portugal - dez/98

Em milhões de escudos

\begin{tabular}{|c|c|c|c|c|c|c|c|c|}
\hline Variáveis & ANO-8 & ANO-7 & ANO-6 & ANO-5 & ANO-4 & ANO-3 & ANO-2 & ANO-1 \\
\hline Patrimônio Líquido & 1289880 & 1732169 & 2087256 & 2343014 & 2522409 & 2556361 & 2953656 & 3360935 \\
\hline Ativo Total & 11764251 & 14952651 & 19178345 & 24715672 & 27990698 & 31073857 & 35572320 & 41362075 \\
\hline Passivo & 10474371 & 13220482 & 17091089 & 22372658 & 25468289 & 28517496 & 32618664 & 38001140 \\
\hline Ativos Líquidos & 5981340 & 7999684 & 9864035 & 12479477 & 14720565 & 16654290 & 19148403 & 20908888 \\
\hline Oper. de Créd. & 4765890 & 5952732 & 8059651 & 8859756 & 9240971 & 10358136 & 11631400 & 13996425 \\
\hline Créditos Anormais & 0,0487 & 0,0398 & 0,0282 & 0,0213 & 0,0165 & 0,0116 & 0,0109 & 0,0107 \\
\hline Depósitos Totais & 8181874 & 9948713 & 12344426 & 13923347 & 15107903 & 16614542 & 17977424 & 19922982 \\
\hline Expos. Câmbio & 50550 & -123390 & 239610 & 1090540 & 1109330 & 521420 & 82080 & -152360 \\
\hline PIB & 9838050 & 11306700 & 12743200 & 13445500 & 14616800 & 16204300 & 17287600 & 18647700 \\
\hline Taxa de Juros & 13,12 & 15,50 & 17,48 & 13,25 & 10,62 & 8,91 & 7,38 & 5,78 \\
\hline Taxa de Câmbio & 190,07 & 191,94 & 201,79 & 242,86 & 232,25 & 222,10 & 224,88 & 247,35 \\
\hline Variação Câmbio & & 0,010 & 0,051 & 0,204 & $-0,044$ & $-0,044$ & 0,013 & 0,100 \\
\hline \multicolumn{9}{|l|}{ Reservas Intern. } \\
\hline \multicolumn{9}{|l|}{ Variação Reservas } \\
\hline \multicolumn{9}{|l|}{ INDPRESCAM } \\
\hline \multicolumn{9}{|l|}{ Crédito privado } \\
\hline \multicolumn{9}{|l|}{ Crédito público } \\
\hline Depósitos vista & 1766650 & 2072770 & 2556660 & 2861630 & 3038670 & 3434960 & 3914560 & 4637880 \\
\hline Depósitos prazo & 5709140 & 7248640 & 8503390 & 9414920 & 10360400 & 11116500 & 11465100 & 11956000 \\
\hline \multicolumn{9}{|l|}{ Lucro-prejuízo } \\
\hline Ativo em FX & 823090 & 1182180 & 2040310 & 3543740 & 4534120 & 5367230 & 5864460 & 8698930 \\
\hline Passivo em FX & 772540 & 1305570 & 1800700 & 2453200 & 3424790 & 4845810 & 5782380 & 8851290 \\
\hline Ativo em TJ & 10941161 & 13770471 & 17138035 & 21171932 & 23456578 & 25706627 & 29707860 & 32663145 \\
\hline Passivo em TJ & 9701831 & 11914912 & 15290389 & 19919458 & 22043499 & 23671686 & 26836284 & 29149850 \\
\hline Expos. Taxa Juros & 1239330 & 1855559 & 1847646 & 1252474 & 1413079 & 2034941 & 2871576 & 3513295 \\
\hline Assist. Financ. BC & 1286074 & 1991752 & 3348603 & 5102124 & 6423324 & 8029496 & 10257649 & 11969288 \\
\hline \multicolumn{9}{|l|}{ Indicador Contábil } \\
\hline ROE & 0,0953 & 0,0913 & 0,0692 & 0,073 & 0,058 & 0,061 & 0,061 & 0,071 \\
\hline ATPL & & & & & 11,097 & 12,156 & 12,043 & 12,307 \\
\hline ALDT & & & & & 0,549 & 0,519 & 0,495 & 0,449 \\
\hline CAOC & & & & & 0,016 & 0,012 & 0,011 & 0,011 \\
\hline NOPPL & & & & & 0,440 & 0,204 & 0,028 & $-0,045$ \\
\hline \multicolumn{9}{|l|}{ Indicador de Riscos } \\
\hline $\operatorname{IRFX}(4,9$ & & & & & 2,637 & 1,560 & 0,146 & $-0,184$ \\
\hline $\operatorname{IRTJ}(4,99 \%)$ & & & & & 3,359 & 6,087 & 5,106 & 4,240 \\
\hline $\operatorname{IRCRE}(4,99 \%)$ & & & & & 0,075 & 0,058 & 0,038 & 0,023 \\
\hline IRDTAL & & & & & 0,542 & 0,423 & 0,401 & 0,462 \\
\hline IRATPIB & & & & & 2,714 & 2,551 & 2,597 & 2,847 \\
\hline
\end{tabular}




\section{PAIIS SEM EXPERIÊNCIA DE CRISE}

31. Reino Unido - dez/98

Variáveis

Patrimônio Líquido

Ativo Total

Passivo

Ativos Líquidos

Oper. de Créd.

Créditos Anormais

Depósitos Totais

Expos. Câmbio

PIB

Taxa de Juros

Taxa de Câmbio

Variação Câmbio

Reservas Intern.

Variação Reservas

INDPRESCAM

Crédito privado

Crédito público

Depósitos vista

Depósitos prazo

Lucro-prejuízo

Ativo em FX

Passivo em FX

Ativo em TJ

Passivo em TJ

Expos. Taxa Juros

Assist. Financ. BC

Indicador Contábil

ROE

ATPL

ALDT

CAOC

NOPPL

Indicador de Riscos

$\operatorname{IRFX}(4,99 \%)$

$\operatorname{IRTJ}(4,99 \%)$

IRCRE(4,99\%)

IRDTAL

IRATPIB

Fontes: OECD (2002); IMF (2003).

24440

532351

507911

132279

322240

0,0214

482020

$-46480$

557300

11,58

0,76
Em milhões de libras esterlinas ANO-7

$\begin{array}{rr}1229 & 805 \\ 516710 & 649720 \\ 563190 & 688160 \\ 15641 & -2866 \\ -55279 & -65824 \\ 70920 & 62958 \\ 0 & 0\end{array}$

3202
686900
712750
3227
-48851
52078
0

5376
741280
764580
-19388
-72208
52820
0

5903

7232

8620

1033980

10198

$845360 \quad 835980$

866810

844330

1051100

1143910

$\begin{array}{llll}-39374 & 179073 & 111363 & 55152\end{array}$

$\begin{array}{llll}-92091 & 128153 & 46531 & 27446\end{array}$

$\begin{array}{llll}52717 & 50920 & 64832 & 27706\end{array}$

$\begin{array}{llll}123328 & 248663 & 130571 & 142039\end{array}$

$\begin{array}{rrrr}0,189 & 0,170 & 0,181 & 0,200 \\ 25,778 & 23,844 & 24,005 & 23,499 \\ 0,362 & 0,097 & 0,323 & 0,310 \\ 0,005 & 0,003 & 0,003 & 0,004 \\ -0,686 & -0,196 & -0,359 & 0,457 \\ & & & \\ -2,820 & -0,219 & -0,518 & 0,566 \\ 6,929 & 1,334 & 1,961 & 0,672 \\ 0,186 & 0,142 & 0,039 & 0,026 \\ 1,115 & 3,838 & 1,432 & 1,497 \\ 1,382 & 1,822 & 2,014 & 1,914\end{array}$




\section{PAÍS SEM EXPERIÊNCIA DE CRISE}

32. Suécia - dez/02

Em milhões de coroas suecas

\begin{tabular}{|c|c|c|c|c|c|c|c|c|}
\hline Variáveis & SEM-8 & SEM-7 & SEM-6 & SEM-5 & SEM-4 & SEM-3 & SEM-2 & SEM-1 \\
\hline Patrimônio Líquido & 76840 & 74370 & 82030 & 82990 & 87520 & 88530 & 97900 & 95950 \\
\hline Ativo Total & 1483089 & 1574519 & 1714245 & 1757187 & 1714688 & 1768377 & 2168303 & 2320696 \\
\hline Passivo & 1406249 & 1500149 & 1632215 & 1674197 & 1627168 & 1679847 & 2070403 & 2224746 \\
\hline Ativos Líquidos & 698493 & 732911 & 775768 & 816290 & 726067 & 752535 & 1074293 & 1131678 \\
\hline Oper. de Créd. & 784596 & 841608 & 938477 & 940897 & 988621 & 1015842 & 1094010 & 1189018 \\
\hline Créditos Anormais & 0,0171 & 0,0158 & 0,0162 & 0,0147 & 0,0129 & 0,0116 & 0,0110 & 0,0103 \\
\hline Depósitos Totais & 740490 & 753290 & 737860 & 748020 & 781040 & 814050 & 827170 & 820670 \\
\hline Expos. Câmbio & -74900 & -105950 & -215800 & -287540 & -244510 & -183310 & -225710 & -295640 \\
\hline PIB & 481610 & 506590 & 500840 & 526560 & 523230 & 560750 & 557720 & 586580 \\
\hline Taxa de Juros & 4,20 & 4,23 & 4,39 & 3,91 & 3,00 & 3,17 & 3,85 & 3,90 \\
\hline Таха & 10,71 & 10,63 & 10,60 & 11,35 & 11,29 & 11,70 & 11,78 & 12,42 \\
\hline Varia & & $-0,007$ & $-0,003$ & 0,071 & $-0,005$ & 0,036 & 0,007 & 0,054 \\
\hline \multicolumn{9}{|l|}{ Reservas Intern. } \\
\hline \multicolumn{9}{|l|}{ Variação Reservas } \\
\hline \multicolumn{9}{|l|}{ INDPRESCAM } \\
\hline Crédito privado & 662470 & 711060 & 767110 & 771670 & 828440 & 848410 & 910310 & 958690 \\
\hline Crédito público & 111770 & 146000 & 165380 & 205510 & 197760 & 129730 & 120300 & 155380 \\
\hline \multicolumn{9}{|l|}{ Depósitos vista } \\
\hline \multicolumn{9}{|l|}{ Depósitos prazo } \\
\hline Lucro-prejuízo & 5979 & -325 & 6963 & 3109 & 5307 & 7525 & 11299 & 6989 \\
\hline Ativo & 711420 & 682150 & 720610 & 698050 & 711920 & 741630 & 893420 & 961140 \\
\hline Passivo em FX & 786320 & 788100 & 936410 & 985590 & 956430 & 924940 & 1119130 & 1256780 \\
\hline Ativo em TJ & 771669 & 892369 & 993635 & 1059137 & 1002768 & 1026747 & 1274883 & 1359556 \\
\hline Passivo em TJ & 619929 & 712049 & 695805 & 688607 & 670738 & 754907 & 951273 & 967966 \\
\hline Expos. & 151740 & 180320 & 297830 & 370530 & 332030 & 271840 & 323610 & 391590 \\
\hline Assist. Financ. BC & 8210 & 31650 & 24110 & 29260 & 38180 & 34440 & 24520 & 45780 \\
\hline \multicolumn{9}{|l|}{ Indicador Contábil } \\
\hline ROE & & & & & 1 & 0,085 & 0,115 & 0,073 \\
\hline ATPL & & & & & 19,592 & 19,975 & 22,148 & 24,187 \\
\hline ALDT & & & & & 0,881 & 0,882 & 1,269 & 1,323 \\
\hline $\mathrm{CAO}$ & & & & & 0,013 & 0,012 & 0,011 & 0,010 \\
\hline NOPPL & & & & & $-2,794$ & $-2,071$ & $-2,306$ & $-3,081$ \\
\hline \multicolumn{9}{|l|}{ Indicador de Riscos } \\
\hline $\operatorname{IRFX}(4,99 \%)$ & & & & & $-3,517$ & $-2,728$ & $-2,247$ & $-2,950$ \\
\hline IRTJ(4,99\%) & & & & & 4,775 & 4,045 & 3,221 & 3,907 \\
\hline IRCRE $(4,99 \%$ & & & & & 0,034 & 0,047 & 0,037 & 0,028 \\
\hline IRDTAL & & & & & 0,054 & 0,097 & 0,068 & 0,038 \\
\hline IRATPIB & & & & & 3,584 & 3,255 & 4,655 & 4,981 \\
\hline
\end{tabular}

Fontes: OECD (2002); IMF (2003). 


\section{APÊNDICE 3: INDICADORES SUBMETIDOS AOS TESTES ESTATÍSTICOS}

\section{Coeficientes de variação}

\begin{tabular}{|c|c|c|c|c|c|c|c|c|c|c|c|}
\hline VDICP & 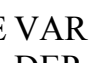 & & & & & & & & & & \\
\hline PAÍS & DEP & ATPL & ALDT & CAOC & NOPPL & ROE & IRFX & IRTJ & IRCRE & IRDT & ATPIB \\
\hline ARG1 & & 0,025 & 0,104 & 0,037 & 0,068 & 6,410 & 0,340 & 0,324 & 0,477 & 0,216 & 0,084 \\
\hline RG2 & & 0,065 & 0,030 & 0,075 & 0,087 & 0,480 & 0,764 & 0,713 & 0,486 & & דיט, \\
\hline QU & & 0,084 & 0,085 & 0,103 & 0,207 & 9,006 & 0,531 & 0,496 & 0,2 & & 01 \\
\hline IDO & & 0,036 & 1,225 & 0,219 & 41 & 0,498 & 0,994 & & 0,460 & & $J$ \\
\hline AI & & 0,045 & 0,254 & 0,148 & 56 & 0,915 & 0,646 & 0,630 & 0,489 & & ,091 \\
\hline OR & & 0,105 & 0,269 & 0,214 & 0,065 & 7,913 & 0,348 & & 0,223 & & 043 \\
\hline EX & & 0,071 & 0,078 & 0,066 & 0,265 & 0,562 & 0,388 & 0,2 & 0 , & & 50. \\
\hline RU & & 0,163 & 0,042 & 0,045 & 2 , & 3,915 & 7,382 & & 0 & & 886 \\
\hline US & & 0,038 & 0,228 & 0,368 &, 050 & 2,241 & 0,399 & 0,425 & 0 , & & 112 \\
\hline UR & & 0,038 & 38 & 0,058 & 42 & 26,771 & 0,497 & & & & 209 \\
\hline ROA & & 0,018 & 0,187 & 0,187 & 0,051 & 0,455 & 0,275 & 0,265 & 0,290 & &, 058 \\
\hline $\mathrm{N}$ & & 0,003 & 0,3 & 0,115 & 0,086 & 1,898 & 0,285 & 0 & 0,1 & & 06 \\
\hline RA95 & & 0,017 & 9 & 06 & 23 & 2,053 & 0,280 & & 0 , & & 025 \\
\hline RA99 & & 0,0 & & 0,138 & 61 & & 0,316 & & & & 49 \\
\hline ULIA & & 0,029 & 0,055 & 0,473 & 0,121 & 0,032 & 0,095 & & 0, & & 122 \\
\hline UST & & 0,06 & 0 , & 0,101 & 0 , & 0,068 & 0,143 & 0,2 & 0,2 & & 017 \\
\hline $\mathrm{AN}$ & & 0 & 0 & 64 & 71 & 3 & 0,572 & & 0 , & & 126 \\
\hline RA & & 0,054 & 0,088 & 0,226 & 0,636 & 32 & 0,601 & 0,239 & 0,267 & & 059 \\
\hline ERM & & 0,019 & & ,203 & & & 0,300 & & & & 80 \\
\hline A & & 0,030 & 0,087 & 0,052 & 0,388 & 0,825 & 0,647 & 0,460 & 0,526 & & 0,062 \\
\hline OLA & & 0,018 & 0,0 & 0,047 & 0 , & 0,055 & 3,887 & 0,2 & 0, & &, 174 \\
\hline ZEL & & 0,122 & 68 & 2,963 & 0,060 & 3 & 0,145 & 40 & 0,676 & &, 129 \\
\hline ORT & & 0,040 & 0,073 & 0,190 & 1,194 & & 1,088 & & 0,405 & & 043 \\
\hline SPA & & 0,030 & 0,0 & 0,271 & 3,906 & & 2,033 & & 0,2 & & 0,056 \\
\hline UE97 & & 0,0 & & 0,084 & & & 0,160 & & & &, 174 \\
\hline $\mathrm{K}$ & & 0,0 & 0,4 & 0,282 & 0,473 & 8 & 0,904 & & 0,4 & &, 165 \\
\hline USA & & 0,015 & 0,014 & 0,113 & 0,182 & 0,012 & 0,329 & & 0,763 & & 0,030 \\
\hline IN97 & & 0,031 & 0,859 & 0,201 & 0,299 & 0,415 & 0,628 & 0 & 0,147 & 4,926 & 0,019 \\
\hline IV & & 0,0 & 0,063 & 0,103 & & & 1,777 & 0,680 & 0,705 & & 0,079 \\
\hline LAI & & 0,036 & & 0,342 & & 0,369 & 0,489 & & & & 0,163 \\
\hline OR95 & & 0,020 & 0,092 & 0,810 & 0,088 & 0,123 & 0,186 & 0,202 & 0,521 & 0,107 & 0,047 \\
\hline VEN88 & & 0,153 & 0,246 & 0,560 & 1,778 & 0,083 & 3,443 & 0,519 & 0,465 & 0,292 & 0,121 \\
\hline
\end{tabular}




\section{Médias}

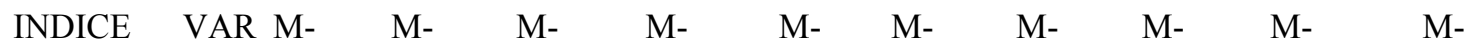
PAÍS DEP ATPL ALDT CAOC NOPPL ROE IRFX IRTJ IRCRE IRDTAL IRATPIB

\begin{tabular}{|c|c|c|c|c|c|c|c|c|c|c|c|}
\hline ARG1 & 1 & 6,745 & 0,099 & 0,195 & $-0,400$ & 0,002 & $-1,143$ & 3,962 & 0,078 & 1,416 & 0,405 \\
\hline ARG2 & 1 & 9,383 & 0,038 & 0,159 & $-0,380$ & 0,011 & $-2,796$ & 9,923 & 0,103 & 1,302 & 0,615 \\
\hline EQU & 1 & 20,713 & 1,454 & 0,079 & $-0,294$ & $-0,009$ & $-3,349$ & 14,521 & 0,241 & 0,065 & 8,405 \\
\hline INDO & 1 & 10,327 & 0,004 & 0,235 & $-1,760$ & 0,061 & $-8,986$ & 13,553 & 0,648 & 25,012 & 3,237 \\
\hline TAI & 1 & 10,203 & 0,082 & 0,026 & $-1,938$ & 0,047 & $-8,827$ & 13,301 & 0,058 & 0,960 & 5,771 \\
\hline KOR & 1 & 15,356 & 0,064 & 0,032 & $-0,284$ & 0,018 & $-0,775$ & 3,461 & 0,214 & 1,828 & 4,621 \\
\hline MEX & 1 & 22,757 & 0,255 & 0,097 & $-0,736$ & 0,166 & $-5,745$ & 13,337 & 0,170 & 0,421 & 0,545 \\
\hline URU & 1 & 11,190 & 0,177 & 0,112 & $-0,200$ & $-0,039$ & $-0,936$ & 13,648 & 0,132 & 0,866 & 336 \\
\hline RUS & 1 & 3,205 & 0,744 & 0,082 & $-0,215$ & 0,010 & $-3,101$ & 17,745 & 0,075 & 0,143 & 0,894 \\
\hline TUR & 1 & 10,444 & 1,147 & 0,107 & $-0,326$ & $-0,001$ & $-8,801$ & 34,616 & 0,116 & 0,219 & 3,711 \\
\hline CROA & 1 & 4,932 & $-0,204$ & 0,138 & $-1,855$ & 0,038 & $-5,920$ & 9,094 & 0,151 & $-0,713$ & 2,935 \\
\hline FIN & 1 & 14,478 & 0,887 & 0,072 & $-2,172$ & $-0,115$ & $-4,769$ & 6,936 & 0,215 & 0,424 & 6,681 \\
\hline BRA95 & 1 & 13,139 & 0,539 & 0,097 & $-0,272$ & $-0,009$ & $-5,180$ & 25,063 & 0,554 & 0,437 & 3,001 \\
\hline BRA99 & 1 & 17,370 & 0,767 & 0,514 & $-0,399$ & $-0,017$ & $-5,787$ & 20,109 & 1,006 & 0,111 & 2,984 \\
\hline AULIA & 0 & 9,764 & 0,135 & 0,003 & $-0,841$ & 0,090 & $-2,109$ & 4,687 & 0,058 & 1,230 & 1,25 \\
\hline AUST & 0 & 21,521 & 0,258 & 0,009 & $-0,343$ & 0,071 & $-1,073$ & 4,542 & 0,025 & 0,507 & 2,614 \\
\hline CAN & 0 & 19,953 & 0,222 & 0,004 & $-0,565$ & 0,135 & $-1,776$ & 4,675 & 0,085 & 0,834 & 1,319 \\
\hline FRA & 0 & 23,435 & 0,356 & 0,013 & 0,178 & 0,019 & 0,662 & 3,265 & 0,057 & 0,311 & 2,572 \\
\hline GERM & 0 & 24,151 & 0,268 & 0,007 & 0,575 & 0,058 & 2,013 & 1,452 & 0,040 & 0,782 & 2,359 \\
\hline ITA & 0 & 15,559 & 0,367 & 0,017 & $-0,650$ & 0,011 & $-2,674$ & 6,364 & 0,025 & 0,283 & 1,608 \\
\hline HOLA & 0 & 23,812 & 0,159 & 0,003 & 0,370 & 0,118 & 0,316 & 3,218 & 0,017 & 1,335 & 3,022 \\
\hline NZEL & 0 & 22,455 & 0,204 & 0,000 & $-4,065$ & 0,202 & $-13,170$ & 16,410 & 0,106 & 0,693 & 1,413 \\
\hline PORT & 0 & 11,901 & 0,503 & 0,012 & 0,157 & 0,063 & 1,040 & 4,698 & 0,048 & 0,457 & 2,67 \\
\hline ESPA & 0 & 11,428 & 0,304 & 0,012 & 0,069 & 0,074 & 0,565 & 3,943 & 0,079 & 0,654 & 1,999 \\
\hline SUE97 & 0 & 21,475 & 1,089 & 0,011 & $-2,563$ & 0,083 & $-2,860$ & 3,987 & 0,036 & 0,064 & 4,119 \\
\hline UK & 0 & 24,520 & 0,221 & 0,005 & $-0,508$ & 0,180 & $-2,137$ & 5,386 & 0,135 & 3,221 & 1,557 \\
\hline USA & 0 & 12,072 & 0,384 & 0,006 & $-0,639$ & 0,129 & $-1,433$ & 3,622 & 0,026 & 0,340 & 0,733 \\
\hline FIN97 & 0 & 11,889 & $-0,019$ & 0,015 & 0,429 & 0,169 & 0,142 & 0,174 & 0,069 & 0,386 & 2,49 \\
\hline DIN95 & 0 & 15,866 & 0,384 & 0,007 & 0,259 & 0,121 & 0,299 & 1,190 & 0,025 & 0,507 & 6,143 \\
\hline ISLAN & 0 & 12,836 & 0,259 & 0,016 & $-1,420$ & 0,073 & $-5,815$ & 10,308 & 0,162 & 0,482 & 0,71 \\
\hline NOR95 & 0 & 14,380 & 0,049 & 0,002 & $-2,001$ & 0,125 & $-7,179$ & 10,836 & 0,018 & 4,715 & 4,416 \\
\hline VEN88 & 1 & 16,356 & 0,161 & 0,072 & 0,066 & 0,240 & 0,945 & 28,046 & 0,398 & 3,758 & 0,0 \\
\hline
\end{tabular}




\section{Desvios-padrão}

\begin{tabular}{|c|c|c|c|c|c|c|c|c|c|c|c|}
\hline CE & IAR & D- & D- & D- & & D- & & & & & 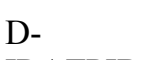 \\
\hline PAÍS & DEP & ATPL & ALDT & CAOC & NOPPL & ROE & IRFX & IRTJ & IRCRE & IRDTAL & IRATPIB \\
\hline ARG1 & & 0,168 & 0,010 & 0,008 & 0,027 & 0,013 & 0,389 & 1,282 & 0,039 & 0,306 & 0,034 \\
\hline ARG2 & & 0,613 & 0,001 & 0,012 & 0,033 & 0,005 & 2,137 & 7,076 & 0,050 & 0,677 & 0,025 \\
\hline EQU & & 1,738 & 0,123 & 0,008 & 0,061 & 0,080 & 1,780 & 7,208 & 0,057 & 0,025 & 0,162 \\
\hline INDO & & 0,372 & 0,005 & 0,051 & 0,249 & 0,030 & 8,934 & 12,798 & 0,298 & 29,279 & 0,160 \\
\hline TAI & & 0,454 & 0,021 & 0,004 & 0,109 & 0,043 & 5,699 & 8,382 & 0,028 & 0,178 & 0,526 \\
\hline KOR & & 1,613 & 0,017 & 0,007 & 0,019 & 0,146 & 0,270 & 1,033 & 0,048 & 0,407 & 0,200 \\
\hline MEX & & 1,621 & 0,020 & 0,006 & 0,195 & 0,093 & 2,228 & 3,028 & 0,024 & 0,072 & 0,046 \\
\hline URU & & 1,823 & 0,007 & 0,005 & 0,417 & 0,154 & 6,909 & 7,339 & 0,016 & 0,083 & 0,115 \\
\hline RUS & & 0,121 & 0,170 & 0,030 & 0,011 & 0,023 & 1,237 & 7,541 & 0,051 & 0,013 & 0,100 \\
\hline TUR & & 0,392 & 0,044 & 0,006 & 0,079 & 0,028 & 4,374 & 13,978 & 0,012 & 0,087 & 0,775 \\
\hline CROA & & 0,089 & 0,038 & 0,026 & 0,095 & 0,017 & 1,628 & 2,407 & 0,044 & 0,616 & 0,169 \\
\hline FIN & & 0,038 & 0,304 & 0,008 & 0,186 & 0,219 & 1,358 & 1,831 & 0,043 & 0,180 & 0,459 \\
\hline BRA95 & & 0,218 & 0,107 & 0,010 & 0,033 & 0,017 & 1,453 & 8,637 & 0,415 & 0,163 & 0,076 \\
\hline BRA99 & & 1,703 & 0,037 & 0,071 & 0,104 & 0,052 & 1,830 & 2,833 & 0,231 & 0,052 & 0,145 \\
\hline AULIA & ( & 0,280 & 0,007 & 0,001 & 0,102 & 0,003 & 0,200 & 0,793 & 0,030 & 0,407 & 0,153 \\
\hline AUST & ( & 1,418 & 0,014 & 0,001 & 0,112 & 0,005 & 0,153 & 1,257 & 0,005 & 0,086 & 0,045 \\
\hline CAN & ( & 1,006 & 0,018 & 0,002 & 0,209 & 0,015 & 1,017 & 1,688 & 0,021 & 0,119 & 0,166 \\
\hline FRA & ( & 1,270 & 0,031 & 0,003 & 0,113 & 0,024 & 0,398 & 0,780 & 0,015 & 0,121 & 0,152 \\
\hline GERM & ( & 0,454 & 0,012 & 0,001 & 0,073 & 0,003 & 0,603 & 0,459 & 0,002 & 0,098 & 0,188 \\
\hline ITA & ( & 0,463 & 0,032 & 0,001 & 0,252 & 0,009 & 1,731 & 2,929 & 0,013 & 0,043 & 0,100 \\
\hline HOLA & ( & 0,435 & 0,011 & 0,000 & 0,149 & 0,007 & 1,227 & 0,650 & 0,008 & 0,450 & 0,525 \\
\hline NZEL & ( & 2,731 & 0,014 & 0,001 & 0,243 & 0,021 & 1,906 & 2,303 & 0,071 & 0,138 & 0,183 \\
\hline PORT & ( & 0,473 & 0,037 & 0,002 & 0,187 & 0,005 & 1,131 & 1,012 & 0,020 & 0,054 & 0,115 \\
\hline ESPA & ( & 0,345 & 0,013 & 0,003 & 0,270 & 0,008 & 1,149 & 0,594 & 0,023 & 0,097 & 0,112 \\
\hline SUE97 & ( & 1,844 & 0,208 & 0,001 & 0,397 & 0,020 & 0,456 & 0,552 & 0,007 & 0,022 & 0,718 \\
\hline UK & ( & 0,759 & 0,104 & 0,001 & 0,240 & 0,007 & 1,931 & 4,053 & 0,058 & 3,453 & 0,257 \\
\hline USA & ( & 0,175 & 0,005 & 0,001 & 0,116 & 0,001 & 0,471 & 0,928 & 0,020 & 0,062 & 0,022 \\
\hline FIN97 & ( & 0,372 & 0,017 & 0,003 & 0,129 & 0,070 & 0,089 & 0,089 & 0,010 & 1,901 & 0,047 \\
\hline DIN95 & ( & 0,579 & 0,024 & 0,001 & 0,339 & 0,003 & 0,531 & 0,810 & 0,018 & 0,058 & 0,483 \\
\hline ISLAN & ( & 0,457 & 0,047 & 0,005 & 0,351 & 0,027 & 2,843 & 5,509 & 0,030 & 0,073 & 0,116 \\
\hline NOR95 & ( & 0,291 & 0,004 & 0,001 & 0,176 & 0,015 & 1,338 & 2,184 & 0,010 & 0,506 & 0,207 \\
\hline VEN88 & & 2,510 & 0,040 & 0,040 & 0,118 & 0,020 & 3,255 & 14,551 & 0,185 & 1,099 & 0,073 \\
\hline
\end{tabular}


APÊNDICE 4: CÁLCULO DA VARIAÇÃO NO INDICADOR DCAOC

\section{Países com experiência de crise}

\begin{tabular}{|c|c|c|c|c|c|}
\hline $\begin{array}{l}\text { coluna } 1 \\
\text { PAÍS }\end{array}$ & $\begin{array}{l}\text { coluna } 2 \\
\text { DCAOC }\end{array}$ & $\begin{array}{c}\text { coluna } 3 \\
\text { Z(i) }\end{array}$ & $\begin{array}{c}\text { coluna } 4 \\
\operatorname{EXP}(-Z(i))\end{array}$ & $\begin{array}{c}\text { coluna } 5 \\
1 / 1+\operatorname{EXP}(-Z(i))\end{array}$ & $\begin{array}{c}\text { Variação na } \\
\text { probabilidade }\end{array}$ \\
\hline ARG1 & 8,308 & 7,4404 & 0,00059 & $99,94 \%$ & \\
\hline DCAOC+1 & 9,308 & 9,3324 & 0,00009 & $99,99 \%$ & $0,05 \%$ \\
\hline ARG2 & 11,993 & 14,4110 & 0,00000 & $100,00 \%$ & \\
\hline DCAOC+1 & 12,993 & 16,3030 & 0,00000 & $100,00 \%$ & $0,00 \%$ \\
\hline EQU & 8,132 & 7,1061 & 0,00082 & $99,92 \%$ & \\
\hline DCAOC+1 & 9,132 & 8,9981 & 0,00012 & $99,99 \%$ & $0,07 \%$ \\
\hline INDO & 51,319 & 88,8159 & 0,00000 & $100,00 \%$ & \\
\hline DCAOC+1 & 52,319 & 90,7079 & 0,00000 & $100,00 \%$ & $0,00 \%$ \\
\hline TAI & 3,840 & $-1,0138$ & 2,75592 & $26,62 \%$ & \\
\hline DCAOC +1 & 4,840 & 0,8782 & 0,41551 & $70,65 \%$ & $165,34 \%$ \\
\hline KOR & 6,880 & 4,7375 & 0,00876 & $99,13 \%$ & \\
\hline DCAOC+1 & 7,880 & 6,6295 & 0,00132 & $99,87 \%$ & $0,74 \%$ \\
\hline MEX & 6,417 & 3,8629 & 0,02101 & $97,94 \%$ & \\
\hline DCAOC+1 & 7,417 & 5,7549 & $\mathbf{0 , 0 0 3 1 7}$ & $99,68 \%$ & $1,78 \%$ \\
\hline URU & 5,048 & 1,2710 & 0,28054 & $78,09 \%$ & \\
\hline DCAOC+1 & 6,048 & 3,1630 & 0,04230 & $95,94 \%$ & $22,86 \%$ \\
\hline RUS & 30,364 & 49,1698 & 0,00000 & $100,00 \%$ & \\
\hline DCAOC +1 & 31,364 & 51,0618 & 0,00000 & $100,00 \%$ & $0,00 \%$ \\
\hline TUR & 6,175 & 3,4036 & 0,03325 & $96,78 \%$ & \\
\hline DCAOC+1 & 7,175 & 5,2956 & 0,00501 & $99,50 \%$ & $2,81 \%$ \\
\hline CROA & 25,793 & 40,5213 & 0,00000 & $100,00 \%$ & \\
\hline DCAOC +1 & 26,793 & 42,4133 & 0,00000 & $100,00 \%$ & $0,00 \%$ \\
\hline FIN & 8,284 & 7,3934 & 0,00062 & $99,94 \%$ & \\
\hline DCAOC+1 & 9,284 & 9,2854 & 0,00009 & $99,99 \%$ & $0,05 \%$ \\
\hline BRA95 & 10,266 & 11,1447 & 0,00001 & $100,00 \%$ & \\
\hline DCAOC+1 & 11,266 & 13,0367 & 0,00000 & $100,00 \%$ & $0,00 \%$ \\
\hline BRA99 & 70,944 & 125,9464 & 0,00000 & $100,00 \%$ & \\
\hline DCAOC +1 & 71,944 & 127,8384 & 0,00000 & $100,00 \%$ & $0,00 \%$ \\
\hline VEN88 & 40,408 & 68,1722 & 0,00000 & $100,00 \%$ & \\
\hline DCAOC +1 & 41,408 & 70,0642 & 0,00000 & $100,00 \%$ & $0,00 \%$ \\
\hline
\end{tabular}


2. Países sem experiência de crise

\begin{tabular}{|c|c|c|c|c|c|}
\hline $\begin{array}{l}\text { coluna } 1 \\
\text { PAIIS }\end{array}$ & $\begin{array}{l}\text { Coluna } 2 \\
\text { DCAOC } \\
\end{array}$ & coluna $3 \mathrm{Z}(\mathrm{i})$ & $\begin{array}{c}\text { coluna } 4 \\
\operatorname{EXP}(-Z(i))\end{array}$ & \begin{tabular}{|c|} 
coluna 5 \\
$1 /\left(1+\mathrm{e}^{\wedge}(-\mathrm{Z}(\mathrm{i}))\right.$ \\
\end{tabular} & $\begin{array}{c}\text { Variação na } \\
\text { probabilidade }\end{array}$ \\
\hline AULIA & 1,344 & $-5,7363$ & 309,91757 & $0,32 \%$ & \\
\hline DCAOC +1 & 2,344 & $-3,8443$ & 46,72626 & $2,10 \%$ & $551,46 \%$ \\
\hline AUST & 0,867 & $-6,6393$ & 764,58255 & $0,13 \%$ & \\
\hline DCAOC +1 & 1,867 & $-4,7473$ & 115,27609 & $0,86 \%$ & $558,42 \%$ \\
\hline CAN & 1,614 & $-5,2250$ & 185,86409 & $0,54 \%$ & \\
\hline DCAOC +1 & 2,614 & $-3,3330$ & 28,02272 & $3,45 \%$ & $543,85 \%$ \\
\hline FRA & 2,894 & $-2,8030$ & 16,49325 & $5,72 \%$ & \\
\hline DCAOC +1 & 3,894 & $-0,9110$ & 2,48669 & $28,68 \%$ & $401,72 \%$ \\
\hline GERM & 1,406 & $-5,6185$ & 275,47229 & $0,36 \%$ & \\
\hline DCAOC+1 & 2,406 & $-3,7265$ & 41,53295 & $2,35 \%$ & $550,02 \%$ \\
\hline ITA & 0,889 & $-6,5979$ & 733,55597 & $0,14 \%$ & \\
\hline DCAOC +1 & 1,889 & $-4,7059$ & 110,59821 & $0,90 \%$ & $558,21 \%$ \\
\hline HOLA & 0,122 & $-8,0476$ & 3126,41725 & $0,03 \%$ & \\
\hline DCAOC +1 & 1,122 & $-6,1556$ & 471,36983 & $0,21 \%$ & $562,07 \%$ \\
\hline NZEL & 0,823 & $-6,7223$ & 830,70689 & $0,12 \%$ & \\
\hline DCAOC+1 & 1,823 & $-4,8303$ & 125,24565 & $0,79 \%$ & $558,80 \%$ \\
\hline PORT & 2,357 & $-3,8202$ & 45,61336 & $2,15 \%$ & \\
\hline DCAOC+1 & 3,357 & $-1,9282$ & 6,87712 & $12,69 \%$ & $491,76 \%$ \\
\hline ESPA & 3,240 & $-2,1498$ & 8,58314 & $10,43 \%$ & \\
\hline DCAOC+1 & 4,240 & $-0,2578$ & 1,29408 & $43,59 \%$ & $317,73 \%$ \\
\hline SUE97 & 0,967 & $-6,4498$ & 632,59941 & $0,16 \%$ & \\
\hline DCAOC +1 & 1,967 & $-4,5578$ & 95,37699 & $1,04 \%$ & $557,42 \%$ \\
\hline UK & 1,300 & $-5,8201$ & 337,01190 & $0,30 \%$ & \\
\hline DCAOC+1 & 2,300 & $-3,9281$ & 50,81127 & $1,93 \%$ & $552,39 \%$ \\
\hline USA & 0,638 & $-7,0726$ & 1179,20638 & $0,08 \%$ & \\
\hline DCAOC +1 & 1,638 & $-5,1806$ & 177,78891 & $0,56 \%$ & $560,11 \%$ \\
\hline FIN97 & 3,111 & $-2,3939$ & 10,95589 & $8,36 \%$ & \\
\hline $\mathrm{DCAOC}+1$ & 4,111 & $-0,5019$ & 1,65182 & $37,71 \%$ & $350,86 \%$ \\
\hline DIN95 & 0,725 & $-6,9067$ & 998,95107 & $0,10 \%$ & \\
\hline DCAOC +1 & 1,725 & $-5,0147$ & 150,61182 & $0,66 \%$ & $559,55 \%$ \\
\hline ISLAN & 5,330 & 1,8061 & 0,16430 & $85,89 \%$ & \\
\hline $\mathrm{DCAOC}+1$ & 6,330 & 3,6981 & 0,02477 & $97,58 \%$ & $13,62 \%$ \\
\hline NOR95 & 1,268 & $-5,8805$ & 358,00211 & $0,28 \%$ & \\
\hline DCAOC+1 & 2,268 & $-3,9885$ & 53,97597 & $1,82 \%$ & $553,02 \%$ \\
\hline
\end{tabular}


APÊNDICE 5: CÁLCULO DO PONTO DE CORTE DAS EQUAÇÕES

1. Equação 2: $P\left(\right.$ crise $\left._{i}\right)=$

1

$1+e^{-\left(-2,147-0,032^{*} M R O E_{i}+0,042^{*} M I R C R E_{i}\right)}$

\begin{tabular}{|l|c|c|c|c|c|}
\hline PAÍSES & M-ROE & M-IRCRE & Z(i) * & EXP(-Zi) & $1 /(1+\mathrm{EXP}(-\mathrm{Zi}))$ \\
\hline ARG1 & 0,0020 & 0,0776 & $-2,1438$ & 8,5318 & 0,1049 \\
\hline ARG2 & 0,0107 & 0,1033 & $-2,1430$ & 8,5250 & 0,1050 \\
\hline EQU & $-0,0089$ & 0,2410 & $-2,1366$ & 8,4706 & 0,1056 \\
\hline INDO & 0,0611 & 0,6482 & $-2,1217$ & 8,3456 & 0,1070 \\
\hline TAI & 0,0467 & 0,0576 & $-2,1461$ & 8,5512 & 0,1047 \\
\hline KOR & 0,0184 & 0,2141 & $-2,1386$ & 8,4875 & 0,1054 \\
\hline MEX & 0,1657 & 0,1703 & $-2,1452$ & 8,5433 & 0,1048 \\
\hline URU & $-0,0393$ & 0,1319 & $-2,1402$ & 8,5012 & 0,1053 \\
\hline RUS & 0,0101 & 0,0750 & $-2,1442$ & 8,5350 & 0,1049 \\
\hline TUR & $-0,0010$ & 0,1163 & $-2,1421$ & 8,5172 & 0,1051 \\
\hline CROA & 0,0382 & 0,1511 & $-2,1419$ & 8,5154 & 0,1051 \\
\hline FIN & $-0,1155$ & 0,2154 & $-2,1343$ & 8,4508 & 0,1058 \\
\hline BRA95 & $-0,0085$ & 0,5543 & $-2,1234$ & 8,3599 & 0,1068 \\
\hline BRA99 & $-0,0166$ & 1,0057 & $-2,1042$ & 8,2008 & 0,1087 \\
\hline VEN88 & 0,2400 & 0,3981 & $-2,1380$ & 8,4821 & 0,1055 \\
\hline AULIA & 0,0905 & 0,0577 & $-2,1475$ & 8,5632 & 0,1046 \\
\hline AUST & 0,0715 & 0,0254 & $-2,1482$ & 8,5696 & 0,1045 \\
\hline CAN & 0,1348 & 0,0850 & $-2,1477$ & 8,5655 & 0,1045 \\
\hline FRA & 0,0192 & 0,0569 & $-2,1452$ & 8,5440 & 0,1048 \\
\hline GERM & 0,0579 & 0,0401 & $-2,1472$ & 8,5606 & 0,1046 \\
\hline ITA & 0,0111 & 0,0252 & $-2,1463$ & 8,5531 & 0,1047 \\
\hline HOLA & 0,1184 & 0,0173 & $-2,1501$ & 8,5854 & 0,1043 \\
\hline NZEL & 0,2020 & 0,1055 & $-2,1490$ & 8,5766 & 0,1044 \\
\hline PORT & 0,0628 & 0,0485 & $-2,1470$ & 8,5589 & 0,1046 \\
\hline ESPA & 0,0735 & 0,0793 & $-2,1460$ & 8,5508 & 0,1047 \\
\hline SUE97 & 0,0835 & 0,0363 & $-2,1481$ & 8,5690 & 0,1045 \\
\hline UK & 0,1848 & 0,0981 & $-2,1488$ & 8,5745 & 0,1044 \\
\hline USA & 0,1287 & 0,0260 & $-2,1500$ & 8,5851 & 0,1043 \\
\hline FIN97 & 0,1687 & 0,0694 & $-2,1495$ & 8,5805 & 0,1044 \\
\hline DIN95 & 0,1212 & 0,0254 & $-2,1498$ & 8,5833 & 0,1043 \\
\hline ISLAN & 0,0730 & 0,1618 & $-2,1425$ & 8,5211 & 0,1050 \\
\hline NOR95 & 0,1253 & 0,0185 & $-2,1502$ & 8,5869 & 0,1043 \\
\hline \multicolumn{1}{|c|}{ VALOR LOCALIZADO NO PERCENTIL 0,53125 =-> } & $\mathbf{0 , 1 0 4 7 8}$ \\
\hline & & Valor mínimo $==>$ & 0,10431 \\
\hline & & & & 0,10869 \\
\hline
\end{tabular}

$* \mathrm{Z}(\mathrm{i})=-2,147-0,032 * \mathrm{MROE}+0,042 * \mathrm{MIRCRE}$ 
2. Equação 4: $P\left(\right.$ crise $\left._{i}\right)=$

1

$\overline{1+e^{-\left(-3,871+0,046^{*} D R O E_{i}+0,001^{*} D I R T J_{i}\right)}}$

\begin{tabular}{|l|c|c|c|c|c|}
\hline PAÍSES & DROE & DIRTJ & Z(i) * & EXP(-Zi) & $1 /(1+\mathrm{EXP}(-\mathrm{Zi}))$ \\
\hline ARG1 & 0,0129 & 1,2821 & $-3,8691$ & 47,9005 & 0,0204 \\
\hline ARG2 & 0,0051 & 7,0762 & $-3,8637$ & 47,6407 & 0,0206 \\
\hline EQU & 0,0797 & 7,2083 & $-3,8601$ & 47,4712 & 0,0206 \\
\hline INDO & 0,0305 & 12,7978 & $-3,8568$ & 47,3138 & 0,0207 \\
\hline TAI & 0,0427 & 8,3818 & $-3,8607$ & 47,4964 & 0,0206 \\
\hline KOR & 0,1456 & 1,0328 & $-3,8633$ & 47,6208 & 0,0206 \\
\hline MEX & 0,0932 & 3,3831 & $-3,8633$ & 47,6238 & 0,0206 \\
\hline URU & 0,1540 & 7,3390 & $-3,8566$ & 47,3031 & 0,0207 \\
\hline RUS & 0,0227 & 7,5411 & $-3,8624$ & 47,5801 & 0,0206 \\
\hline TUR & 0,0281 & 13,9784 & $-3,8557$ & 47,2631 & 0,0207 \\
\hline CROA & 0,0174 & 2,4074 & $-3,8678$ & 47,8366 & 0,0205 \\
\hline FIN & 0,2192 & 1,8312 & $-3,8591$ & 47,4221 & 0,0207 \\
\hline BRA95 & 0,0175 & 8,6367 & $-3,8616$ & 47,5394 & 0,0206 \\
\hline BRA99 & 0,0520 & 2,8332 & $-3,8658$ & 47,7402 & 0,0205 \\
\hline VEN88 & 0,0199 & 28,1518 & $-3,8419$ & 46,6155 & 0,0210 \\
\hline AULIA & 0,0029 & 0,7926 & $-3,8701$ & 47,9460 & 0,0204 \\
\hline AUST & 0,0048 & 1,2567 & $-3,8695$ & 47,9194 & 0,0204 \\
\hline CAN & 0,0153 & 1,6884 & $-3,8686$ & 47,8758 & 0,0205 \\
\hline FRA & 0,0237 & 0,7803 & $-3,8691$ & 47,9007 & 0,0204 \\
\hline GERM & 0,0030 & 0,4592 & $-3,8704$ & 47,9618 & 0,0204 \\
\hline ITA & 0,0092 & 2,9286 & $-3,8677$ & 47,8299 & 0,0205 \\
\hline HOLA & 0,0065 & 0,6498 & $-3,8700$ & 47,9448 & 0,0204 \\
\hline NZEL & 0,0207 & 2,3033 & $-3,8677$ & 47,8343 & 0,0205 \\
\hline PORT & 0,0051 & 1,0123 & $-3,8698$ & 47,9305 & 0,0204 \\
\hline ESPA & 0,0079 & 0,5935 & $-3,8700$ & 47,9445 & 0,0204 \\
\hline SUE97 & 0,0204 & 0,5518 & $-3,8695$ & 47,9190 & 0,0204 \\
\hline UK & 0,0110 & 2,4702 & $-3,8680$ & 47,8478 & 0,0205 \\
\hline USA & 0,0015 & 0,9278 & $-3,8700$ & 47,9426 & 0,0204 \\
\hline FIN97 & 0,0699 & 0,0895 & $-3,8677$ & 47,8319 & 0,0205 \\
\hline DIN95 & 0,0032 & 0,8099 & $-3,8700$ & 47,9445 & 0,0204 \\
\hline ISLAN & 0,0269 & 5,5088 & $-3,8643$ & 47,6676 & 0,0205 \\
\hline NOR95 & 0,0154 & 2,1843 & $-3,8681$ & 47,8518 & 0,0205 \\
\hline \multicolumn{1}{|c|}{ VALOR LOCALIZADO NO PERCENTIL 0,53125 ==> } & $\mathbf{0 , 0 2 0 4 8}$ \\
\hline & & Valor mínimo ==> & 0,02042 \\
\hline & & & & 0,02100 \\
\hline
\end{tabular}

$* \mathrm{Z}(\mathrm{i})=-3,871+0,046 *$ DROE $+0,001 *$ DIRTJ 
3. Equação 5: $P\left(\right.$ crise $\left._{i}\right)=\frac{1}{1+e^{-\left(-8,279+1,892 * D C A O C_{i}\right)}}$

\begin{tabular}{|l|c|c|c|c|}
\hline PAÍSES & DCAOC & Z(i) $*$ & EXP(-Zi) & $1 /(1+\mathrm{EXP}(-\mathrm{Zi}))$ \\
\hline ARG1 & 0,0083 & $-8,26328$ & 3878,7978 & 0,000258 \\
\hline ARG2 & 0,0120 & $-8,25631$ & 3851,8546 & 0,000260 \\
\hline EQU & 0,0081 & $-8,26361$ & 3880,0948 & 0,000258 \\
\hline INDO & 0,0513 & $-8,18191$ & 3575,6602 & 0,000280 \\
\hline TAI & 0,0038 & $-8,27173$ & 3911,7290 & 0,000256 \\
\hline KOR & 0,0069 & $-8,26598$ & 3889,2960 & 0,000257 \\
\hline MEX & 0,0064 & $-8,26686$ & 3892,6994 & 0,000257 \\
\hline URU & 0,0050 & $-8,26945$ & 3902,8018 & 0,000256 \\
\hline RUS & 0,0304 & $-8,22155$ & 3720,2687 & 0,000269 \\
\hline TUR & 0,0062 & $-8,26732$ & 3894,4876 & 0,000257 \\
\hline CROA & 0,0258 & $-8,23020$ & 3752,5829 & 0,000266 \\
\hline FIN & 0,0083 & $-8,26333$ & 3878,9803 & 0,000258 \\
\hline BRA95 & 0,0103 & $-8,25958$ & 3864,4564 & 0,000259 \\
\hline BRA99 & 0,0709 & $-8,14477$ & 3445,3288 & 0,000290 \\
\hline VEN88 & 0,0404 & $-8,20255$ & 3650,2421 & 0,000274 \\
\hline AULIA & 0,0013 & $-8,27646$ & 3930,2460 & 0,000254 \\
\hline AUST & 0,0009 & $-8,27736$ & 3933,7967 & 0,000254 \\
\hline CAN & 0,0016 & $-8,27595$ & 3928,2370 & 0,000255 \\
\hline FRA & 0,0029 & $-8,27352$ & 3918,7341 & 0,000255 \\
\hline GERM & 0,0014 & $-8,27634$ & 3929,7830 & 0,000254 \\
\hline ITA & 0,0009 & $-8,27732$ & 3933,6338 & 0,000254 \\
\hline HOLA & 0,0001 & $-8,27877$ & 3939,3407 & 0,000254 \\
\hline NZEL & 0,0008 & $-8,27744$ & 3934,1230 & 0,000254 \\
\hline PORT & 0,0024 & $-8,27454$ & 3922,7225 & 0,000255 \\
\hline ESPA & 0,0032 & $-8,27287$ & 3916,1754 & 0,000255 \\
\hline SUE97 & 0,0010 & $-8,27717$ & 3933,0514 & 0,000254 \\
\hline UK & 0,0009 & $-8,27730$ & 3933,5515 & 0,000254 \\
\hline USA & 0,0006 & $-8,27779$ & 3935,5015 & 0,000254 \\
\hline FIN97 & 0,0031 & $-8,27311$ & 3917,1314 & 0,000255 \\
\hline DIN95 & 0,0007 & $-8,27763$ & 3934,8487 & 0,000254 \\
\hline ISLAN & 0,0053 & $-8,26891$ & 3900,7141 & 0,000256 \\
\hline NOR95 & 0,0013 & $-8,27660$ & 3930,8129 & 0,000254 \\
\hline VALOR LOCALIZADO NO PERCENTIL 0,53125==> & $\mathbf{0 , 0 0 0 2 5 6}$ \\
\hline & & & Valor mínimo ==> & 0,000254 \\
\hline Valor máximo=-> & 0,000290 \\
\hline Z(i) -8,279 & & &
\end{tabular}

$* \mathrm{Z}(\mathrm{i})=-8,279+1,892 * \mathrm{DCAOC}$ 


\section{APÊNDICE 6: CÁLCULO DOS ÍNDICES DE RISCO SISTÊMICO (IRS) POR PAÍS}

\section{Brasil - mar/1995 a set/2005}

\begin{tabular}{|c|c|c|c|c|c|c|c|c|c|c|c|}
\hline \multirow[t]{2}{*}{ Período } & \multicolumn{2}{|c|}{ Indicadores } & \multirow{2}{*}{ Eq. 2} & \multirow{2}{*}{\begin{tabular}{|c|} 
IRS2 \\
0,10478 \\
\end{tabular}} & \multicolumn{2}{|c|}{ Indicadores } & \multirow{2}{*}{ Eq. 4} & \multirow{2}{*}{\begin{tabular}{|c|} 
IRS4 \\
0,02048 \\
\end{tabular}} & \multirow{2}{*}{\begin{tabular}{|l|} 
Indicad \\
DCAOC \\
\end{tabular}} & \multirow[t]{2}{*}{ Eq. 5} & \multirow{2}{*}{\begin{tabular}{|c|} 
IRS 5 \\
0,00026 \\
\end{tabular}} \\
\hline & MROE & MIRCRE & & & DROE & DIRTJ & & & & & \\
\hline ar-95 & 0,0030 & 0,9947 & 0,1086 & 3,7994 & 0,0034 & 6,9757 & 0,0206 & 0,7645 & 0,0891 & 0,00 & 44,4760 \\
\hline jun-95 & 0067 & 686 & 1085 & 6820 & 0,0057 & 8733 & 0,0206 & 64 & 0,0800 & 0003 & ,3140 \\
\hline set-95 & $\mid-0,0005$ & 0,7006 & 0,1074 & 2,6206 & 0,0162 & 13,2162 & 0,0207 & 1446 & 0,0145 & 0,0003 & 4,9178 \\
\hline dez-95 & $-0,0085$ & 0,5543 & 0,1068 & 2,0572 & 0,0175 & 8,6367 & 0,0206 & 2299 & 0,0103 &, 0003 & 8516 \\
\hline mar-96 & $|-0,0128|$ & 0,3358 & 1060 & 974 & 0,0166 & 0847 &, 0206 & & 0,0103 & 0003 & 8878 \\
\hline jun-96 & $-0,0515$ & 0,1241 & 0,1053 & 0,4746 & 0,0512 & 9,1112 & 0,0206 & 1,6392 & 0,0106 & 0,0003 & 0222 \\
\hline set-96 & $\mid-0,0381$ & 0,1234 & 0,1052 & 0,4314 & 0,0617 & 6,1824 & 0,0206 & 1,1452 & 0,0150 & 0,0003 & ,1726 \\
\hline dez-96 & $|-0,0168|$ & & 0,1053 & 5082 & 0,0762 & & 0,0207 & & 0228 & 0003 & 0651 \\
\hline mar-97 & $\mid-0,0007$ & 0,2126 & 0,1055 & 0,6717 & 0,0814 & 9,0906 & 0,0207 & ,9155 & 0,0274 & 0,0003 & ,3498 \\
\hline jun-97 & 0,0559 & 0,2855 & 0,1056 & 0,7900 & 0,0219 & 5,4894 & 0,0205 & 0,6364 & 0,0305 & 0,0003 & ,9524 \\
\hline set-97 & 0,0586 & 650 & 0,1059 & 972 & 0,0183 & 2,3053 & 0,0205 & 359 & 0,0390 & 0003 & 3142 \\
\hline dez-97 & 0,0271 & 0,4459 & 0,1063 & 1,5155 & 0,0558 & 6,5038 & 0,0206 & 1,1550 & 0,0564 & 0,0003 &, 4436 \\
\hline mar-98 & 0,0070 & 0,6138 & 0,1070 & 2,2485 & 0,0587 & 8,4843 & 0,0206 & 1,5825 & 0,0871 & 0,0003 & 2927 \\
\hline jun-98 & $-0,0370$ & 0,8450 & 0,1081 & 3,3155 & 0,0476 & & 0,0206 & 3407 & 1182 & 0003 & 4693 \\
\hline set-98 & \begin{tabular}{|l|}
$-0,0462$ \\
\end{tabular} & 0,9859 & 0,1087 & 3,9162 & 0,0338 & 2,2420 & 0,0205 & 0,0945 & 0,0890 & 0,0003 & 4037 \\
\hline dez-98 & $|-0,0166|$ & 1,0057 & 0,1087 & 3,9051 & 0,0520 & 2,8332 & 0,0205 & 814 & 0,0709 & 0,0003 & 3138 \\
\hline mar-99 & 0,0553 & 1,0943 & 0,1088 & 4,0426 & 0,0740 & 192 & 0,0205 & 614 & 0,1534 & 0003 & ,2772 \\
\hline jun-99 & 0,1038 & 1,3022 & 0,1095 & 4,7410 & 0,0555 & 2,3973 & 0,0205 & 0,3256 & 0,1773 & 0,0004 & 98,9602 \\
\hline set-99 & 0,1071 & 1,1039 & 0,1087 & 3,9208 & 0,0369 & & 0,0205 & 212 & 0078 & 0003 & 6471 \\
\hline dez-99 & 0,1004 & 0,8723 & 0,1078 & 3,0027 & 0,0312 & 390 & 0,0205 & 1301 & 0221 & 0003 & 6904 \\
\hline mar-00 & 0,0801 & 0,5937 & 0,1067 & 1,9443 & 0,0420 & 4,6075 & 0,0205 & 0,6450 & 0,0572 & 0,0003 & 8488 \\
\hline jun- 00 & 0,0629 & 0,3177 & 0,1057 & 8965 & 0,0197 & 1338 & 0,0206 & 1,3509 & 0,0673 & 0003 & ,3225 \\
\hline set-00 & 0,0574 & 0,4331 & 0,1062 & 1,3720 & 0,0215 & 9,2673 & 0,0206 & 1,3945 & 0,0647 & 0,0003 & 30,9257 \\
\hline dez- 00 & 0,0482 & 0,3995 & 0,1060 & 1,2662 & 0,0173 & 4,4610 & 0,0205 & 374 & 0,0051 & 0,0003 & 3438 \\
\hline mar-01 & 0,0527 & 0,2975 & 0,1056 & 0,8470 & 0,0141 & 0,6829 & 0,0204 & $-0,3999$ & 0,0067 & 0003 & 0899 \\
\hline jun-01 & 0,0175 & 0,1660 & 0,1052 & 0,4324 & 0,0472 & 0,7582 & 0,0205 & $-0,0802$ & 0,0059 & 0,0003 & ,7199 \\
\hline set-01 & 0,0270 & 0,0382 & 0,1047 & $-0,1003$ & 0,0545 & 1,0376 & 0,0205 & 441 & 0,0024 & 0,0003 & \begin{tabular}{|l|}
$-0,9585$ \\
\end{tabular} \\
\hline dez-01 & 0,0376 & 0,0343 & 0,1046 & $-0,1473$ & 0,0604 & 1,1929 & 0,0205 & 296 & 0,0042 & 0003 & \begin{tabular}{|l|}
$-0,0826$ \\
\end{tabular} \\
\hline mar-02 & 0,0396 & 0,0268 & 0,1046 & $-0,1828$ & 0,0609 & 1,2231 & 0,0205 & 0,1398 & 0,0043 & 0,0003 & $-0,0534 \mid$ \\
\hline jun- 02 & 0,0905 & 0,0243 & 0,1044 & $-0,3449$ & 0,0303 & 1,6500 & 0,0205 & $-0,0567$ & 0,0042 & 0,0003 & $|-0,0797|$ \\
\hline set-02 & 0,0921 & 0,0276 & 0,1044 & $-0,3369$ & 0,0299 & 1,6799 & 0,0205 & $-0,0543$ & 0,0046 & 0,0003 & 0,1132 \\
\hline dez-02 & 0,1054 & 0,0272 & 0,1044 & $-0,3784$ & 0,0354 & 1,3510 & 0,0205 & $-0,0698$ & 0,0042 & 0,0003 & $-0,1174$ \\
\hline mar-03 & 0,1076 & 0,0244 & 0,1044 & $-0,3960$ & 0,0325 & 2,2843 & 0,0205 & 0,0907 & 0,0029 & 0,0003 & $\mid-0,7090$ \\
\hline jun-03 & 0,0992 & 0,0200 & 0,1044 & $-0,3880$ & 0,0271 & 2,3034 & 0,0205 & 0,0446 & 0,0021 & 0,0003 & $-1,1346$ \\
\hline set-03 & 0,0898 & 0,0149 & 0,1044 & $-0,3798$ & 0,0350 & 1,1067 & 0,0205 & $-0,1222$ & 0,0022 & 0,0003 & \begin{tabular}{|l}
$-1,0866$ \\
\end{tabular} \\
\hline dez- 03 & 0,0790 & 0,0110 & 0,1044 & $-0,3630$ & 0,0227 & 0,8705 & 0,0205 & $-0,2828$ & 0,0021 & 0,0003 & \begin{tabular}{|l|}
$-1,1239$ \\
\end{tabular} \\
\hline mar-04 & 0,0735 & 0,0102 & 0,1044 & $-0,3495$ & 0,0276 & 0,9309 & 0,0205 & $-0,2262$ & 0,0023 & 0,0003 & \begin{tabular}{|l|}
$-0,9966$ \\
\end{tabular} \\
\hline jun-04 & \begin{tabular}{|l|}
0,0710 \\
\end{tabular} & 0,0113 & 0,1044 & $-0,3380$ & 0,0248 & 1,8705 & 0,0205 & $-0,0633$ & 0,0028 & 0,0003 & \begin{tabular}{|l}
$-0,7955$ \\
\end{tabular} \\
\hline set-04 & 0,0699 & 0,0122 & 0,1045 & $-0,3312$ & 0,0258 & 3,1322 & 0,0205 & 0,1991 & 0,0027 & 0,0003 & $|-0,8446|$ \\
\hline dez-04 & 0,0677 & 0,0135 & 0,1045 & $-0,3193$ & 0,0238 & 2,7582 & 0,0205 & $\mathbf{0 , 1 0 5 5}$ & 0,0029 & 0,0003 & \begin{tabular}{|l}
$-0,7412$ \\
\end{tabular} \\
\hline mar- 05 & 0,0710 & 0,0130 & 0,1045 & $-0,3312$ & 0,0208 & 1,0660 & 0,0205 & $-0,2611$ & 0,0018 & 0,0003 & $-1,2615$ \\
\hline jun- 05 & 0,0744 & 0,0110 & 0,1044 & $-0,3492$ & 0,0252 & 0,9048 & 0,0205 & $-0,2536$ & 0,0011 & 0,0003 & 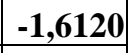 \\
\hline set-05 & $|0,0767|$ & 0,0089 & 0,1044 & $-0,3645$ & 0,0226 & 0,5682 & 0,0204 & $-0,3442$ & 0,0009 & 0,0003 & $-1,691$ \\
\hline
\end{tabular}


2. Argentina - dez/1994 a jun/2005

\begin{tabular}{|c|c|c|c|c|c|c|c|c|c|c|c|}
\hline \multirow[t]{2}{*}{ Período } & \multicolumn{2}{|c|}{ Indicadores } & \multirow[t]{2}{*}{ Eq. 2} & \multirow{2}{*}{\begin{tabular}{|c|} 
IRS2 \\
0,10478 \\
\end{tabular}} & \multicolumn{2}{|c|}{ Indicadores } & \multirow[t]{2}{*}{ Eq. 4} & \multirow{2}{*}{\begin{tabular}{|c|} 
IRS4 \\
0,02048 \\
\end{tabular}} & \multirow{2}{*}{\begin{tabular}{|l|} 
Indicad \\
DCAOC \\
\end{tabular}} & \multirow[t]{2}{*}{ Eq. 5} & \multirow{2}{*}{$\begin{array}{c}\text { IRS } 5 \\
0,00026 \\
\end{array}$} \\
\hline & & MIRCRE & & & DROE & $\mathrm{TJ}$ & & & & & \\
\hline-94 & 0,0031 & 0,0782 & 1049 & 1,2926 & 0,0123 & 0,9845 & 0,0204 & $-0,3562$ & 0,0049 & 0,0003 & 0,2389 \\
\hline mar-95 & 0,0019 & 0,1132 & 1051 & 2,7093 & 0,0124 & 3,6479 & 0,0205 & $\mathbf{0 , 1 7 9 2}$ & 0,0142 & 0,0003 & 7950 \\
\hline jun-95 & $-0,0078$ & 43 & 1052 & & 0,0205 & 3,7821 & 0,0205 & 0,2807 & 0,0225 & 0,0003 & 9228 \\
\hline set-95 & $-0,0122$ & 576 & 1053 & & 0,0152 & 7441 & 0,0205 & 239 & 190 & 0,0003 & 837 \\
\hline dez-95 & $-0,0086$ & &, 1053 & & 0,0160 & 0,8675 & 0,0204 & & 097 & 0,0003 & 704 \\
\hline mar-96 & $-0,0065$ & & 1053 & & 0,0173 & 3,6636 & 0,0205 & 2271 & 0092 & 0,0003 & 093 \\
\hline jun-96 & 0,0041 & 196 & 1052 & & 028 & 8617 & 0,0205 & 3339 & 0154 & 0,0003 & 3901 \\
\hline set-96 & 0,0055 & 0,1423 & 0,1052 & 3,7512 & 0,0032 & 4,5534 & 0,0205 & 0,2759 & 0,0156 & 0,0003 & 4724 \\
\hline dez-96 & 0,0061 & & 052 & & & 113 & 0,0204 & & 167 & 0003 & 360 \\
\hline mar-97 & 0,0085 & & 0,1052 & & & & 204 & & 100 & 0003 & 096 \\
\hline jun-97 & 0,0149 & &, 1052 & & 0,0111 & 813 & 0204 & 382 & 134 &, 0003 & 765 \\
\hline set-97 & 0,0142 & 31 &, 1052 & 23 & 0,0115 & 197 & 0,0204 & 363 & 127 & 0003 & 428 \\
\hline dez-97 & 0,0124 & 78 &, 1051 & 64 & 0,0137 & 0,7282 & 0,0204 & 948 & 103 & 0,0003 & 684 \\
\hline mar-98 & 0,0103 & 25 & 0,1051 & 07 & 135 & 790 & 204 & 866 & 041 & 0,0003 & 340 \\
\hline jun-98 & 0,0041 & & 0,1050 & & & & 204 & & 063 & 0,0003 & \\
\hline set-98 & & & 0,1050 & & & & 204 & & 076 & & \\
\hline dez-98 & 0,0066 & & 0,1048 & & 0,0039 & 0,3673 & 0,0204 & 573 & 010 & 0,0003 & 436 \\
\hline mar-99 & 0,0083 & 0,0489 & 0,1048 & 84 & 0,0046 & 0,4183 & 0,0204 & -0 & 026 & 0,0003 & 776 \\
\hline jun-99 & 0,0079 & 0,0323 & 0,1047 & \begin{tabular}{|l|}
$-0,6626$ \\
\end{tabular} & 0,0044 & 558 & 0,0204 & 950 & 037 & 0,0003 & 553 \\
\hline set-99 & 0,0072 & 493 & 0,1048 & 276 & 0,0040 & 208 & 0,0204 & 858 & 0075 & 003 & 928 \\
\hline dez-99 & 0,0046 & 0664 & 0,1049 & 23 & 0,0080 & 212 & 0,0204 & 482 & 060 & 0003 & 578 \\
\hline mar-00 & & & 0,1049 & & & & & & & 0003 & 278 \\
\hline jun-00 & & & 0,1050 & & & & 204 & & & 003 & 115 \\
\hline set-00 & $-0,0046$ & & 049 & & & & 204 & -1 & 052 & 003 & 616 \\
\hline dez-00 & $-0,0002$ & 0,0621 & 0,1049 & 68 & 0,0153 & 1,5209 & 0,0205 & 11 & 014 & 0003 & 653 \\
\hline mar-01 & 0,0086 & 0,0712 & 0,1049 & 0,8501 & 0,0025 & 2,2362 & 0,0205 & 1955 & 096 & 0,0003 & 5216 \\
\hline jun-01 & 0,0122 &, 0846 & 0,1049 & 1,2677 & 0,0042 & & 0,0205 & $-0,2403$ & 097 & 0,0003 & 890 \\
\hline set-01 & & & 0,1050 & & & & 0,0206 & 0,7961 & 120 & 0,0003 & 6978 \\
\hline dez-01 & $-0,0$ & & 0,1053 & & & & 209 & & 236 & 003 & 700 \\
\hline mar-02 & -0 & & 056 & & & & 211 & 20 & 197 & 003 & 301 \\
\hline jun-02 & $-0,1150$ & 0,2163 & 0,1058 & 10 , & 0,1053 & 695 & 0,0210 & 59 & 136 & 003 & 645 \\
\hline set-02 & $-0,1612$ & 0,2460 & 0,1061 & 12,9024 & 0,0797 & 824 & 0,0208 & & 213 & 0,0003 & \\
\hline dez-02 & & 0,2479 & 0,1061 & 13,6319 & 0,0493 & & 0,0208 & 3,6126 & & 0,0003 & 794 \\
\hline mar-03 & $-0,1605$ & 0,2466 & 0,1061 & 12,9058 & 0,0676 & & 0,0208 & 2,8629 & 0,0190 & 0,0003 & ,1469 \\
\hline jun-03 & $-0,1215$ & 0,2676 & 0,1060 & 12,5602 & 0,0370 & 9,6541 & 0,0206 & 1,6164 & 0,0176 & 0,0003 & 4589 \\
\hline set- 03 & $-0,0886$ & 0,2479 & 0,1059 & 10,7768 & 0,0284 & 13,1474 & 0,0207 & 2,2441 & 0,0124 & 0,0003 & 222 \\
\hline dez-03 & $-0,0622$ & & 0,1056 & & & 7729 & 0,0207 & & & 003 & \\
\hline mar-04 & $-0,0552$ & 0,1838 & 0,1055 & 7,2204 & 0,0311 & & 0,0205 & 0,5241 & 0,0143 & 0,0003 & 8558 \\
\hline jun-04 & $-0,0234$ & 0,2103 & 0,1055 & 7,3151 & 0,0296 & 6,7286 & 0,0206 & 0,9576 & 0,0219 & 0,0003 & 3,6220 \\
\hline set-04 & $-0,0098$ & 0,2541 & 0,1056 & 8,6379 & 0,0277 & 7,3465 & 0,0206 & 1,0649 & 0,0220 & 0,0003 & 8,6816 \\
\hline dez-04 & $-0,0103$ & 0,2994 & 0,1058 & 10,4507 & 0,0279 & 5,8993 & 0,0206 & 0,7747 & 0,0166 & 0,0003 & $\mathbf{9 , 9 7 7 0}$ \\
\hline mar-05 & 0,0023 & 0,3059 & 0,1058 & \begin{tabular}{|l|}
10,3277 \\
\end{tabular} & 0,0152 & 1,7208 & 0,0205 & $-0,1816$ & 0,0168 & 0,0003 & 6,0604 \\
\hline jun-05 & 0,0009 & 0,2835 & 0,1057 & 9,4802 & 0,0134 & 1,5102 & 0,0205 & $-0,2403$ & 0,0174 & 0,0003 & 6,3643 \\
\hline
\end{tabular}


3. México - set/1995 a set/2005

\begin{tabular}{|c|c|c|c|c|c|c|c|c|c|c|c|}
\hline \multirow[t]{2}{*}{ Período } & \multicolumn{2}{|c|}{ Indicadores } & \multirow[t]{2}{*}{ Eq. 2} & \multirow{2}{*}{\begin{tabular}{|c|} 
IRS2 \\
0,10478 \\
\end{tabular}} & \multicolumn{2}{|c|}{ Indicadores } & \multirow[t]{2}{*}{ Eq. 4} & \multirow{2}{*}{\begin{tabular}{|c|} 
IRS4 \\
0,02048 \\
\end{tabular}} & \multirow{2}{*}{\begin{tabular}{|l|} 
Indicad \\
DCAOC
\end{tabular}} & \multirow[t]{2}{*}{ Eq. 5} & \multirow{2}{*}{$\begin{array}{l}\text { IRS } 5 \\
0,0003 \\
\end{array}$} \\
\hline & MROE & MIRCRE & & & DROE & DIRTJ & & & & & \\
\hline set-95 & $-0,270$ & 0,644 & 0,108 & 32,23 & 0,19 & 13,56 & 0,021 & 3,84 & 0,010 & 0,000 & 2,881 \\
\hline dez-95 & $-0,457$ & 0,503 & 0,108 & 32,27 & 0,26 & 11,07 & 0,021 & 3,98 & 0,010 & 0,000 & 2,561 \\
\hline mar-96 & $-0,919$ & 0,486 & 0,109 & 45,93 & 0,62 & 20,93 & 0,021 & 9,49 & 0,008 & 0,000 & 1,96 ? \\
\hline jun-96 & $-1,770$ & 0,528 & 0,112 & 74,47 & 1,27 & 22,83 & 0,022 & 16,21 & 0,008 & 0,000 & 1,977 \\
\hline set-96 & $-1,872$ & 0,422 & 0,112 & 73,27 & 1,18 & 27,49 & 0,022 & 16,32 & 0,009 & 0,000 & 2,317 \\
\hline dez-96 & $-2,008$ & 0,364 & 0,112 & 75,20 & 1,07 & 15,10 & 0,022 & 12,65 & 0,004 & 0,000 & $\mathbf{0 , 0 3 5}$ \\
\hline mar-97 & $-2,031$ & 0,500 & 0,113 & 81,61 & 1,07 & 12,91 & 0,022 & 12,18 & 0,037 & 0,000 & 16,357 \\
\hline jun-97 & $-1,653$ & 0,636 & 0,112 & 75,28 & 0,52 & 7,56 & 0,021 & 5,77 & 0,043 & 0,000 & 19,298 \\
\hline set-97 & $-2,058$ & 0,875 & 0,115 & 98,40 & 0,44 & 4,04 & 0,021 & 4,25 & 0,038 & 0,000 & 16,716 \\
\hline dez-97 & $-7,836$ & 2,280 & 0,142 & 370,11 & 9,61 & 1,07 & 0,031 & 109,54 & 0,022 & 0,000 & 8,691 \\
\hline mar-98 & $-8,191$ & 2,274 & 0,143 & 383,67 & 9,41 & 4,75 & 0,031 & 107,93 & 0,026 & 0,000 & 10,531 \\
\hline jun- 98 & $-9,448$ & 2,457 & 0,149 & 443,46 & 8,85 & 6,12 & 0,031 & 100,65 & 0,024 & 0,000 & 9,496 \\
\hline set-98 & $-12,570$ & 2,502 & 0,163 & 577,26 & 8,04 & 7,20 & 0,029 & 90,08 & 0,008 & 0,000 & 1,969 \\
\hline dez-98 & $-10,228$ & 1,423 & 0,147 & 420,16 & 5,04 & 13,20 & 0,026 & 54,50 & 0,008 & 0,000 & 1,657 \\
\hline mar-99 & $\mid-38,182$ & $-0,811$ & 0,277 & 1722,51 & 44,63 & 24,71 & 0,143 & 1221,79 & 0,007 & 0,000 & 1,413 \\
\hline jun-99 & $-37,906 \mid$ & $-1,414$ & 0,270 & 1654,58 & 44,82 & 24,82 & 0,144 & 1232,82 & 0,012 & 0,000 & 3,759 \\
\hline set-99 & $-41,794 \mid$ & $-2,882$ & 0,283 & 1780,16 & 51,97 & 22,72 & 0,189 & 1683,69 & 0,011 & 0,000 & 3,345 \\
\hline dez-99 & $-17,500$ & 4,160 & 0,196 & 910,95 & 17,63 & 18,48 & 0,046 & 251,10 & 0,030 & 0,000 & 12,614 \\
\hline mar-00 & $-28,139$ & 0,562 & 0,227 & 1226,40 & 17,22 & 22,49 & 0,045 & 244,58 & 0,024 & 0,000 & 9,761 \\
\hline jun- 00 & $-28,855$ & $-2,145$ & 0,212 & 1070,82 & 14,96 & 22,27 & 0,041 & 202,02 & 0,029 & 0,000 & 12,098 \\
\hline set- 00 & $|-35,167|$ & $-0,289$ & 0,262 & 1575,72 & 5,35 & 24,31 & 0,027 & 60,97 & 0,020 & 0,000 & 7,464 \\
\hline dez-00 & $|-84,397|$ & $-20,592$ & 0,423 & 3180,45 & 89,51 & 30,65 & 0,569 & 5483,20 & 0,023 & 0,000 & 9,037 \\
\hline mar-01 & $\mid-79,955$ & $-18,727 \mid$ & 0,407 & 3025,57 & 92,10 & 32,38 & 0,598 & 5776,94 & 0,019 & 0,000 & 6,964 \\
\hline jun-01 & $\mid-76,339$ & $-16,705$ & 0,400 & 2951,46 & 94,21 & 32,55 & 0,621 & 6008,33 & 0,014 & 0,000 & 4,734 \\
\hline set-01 & $-72,036$ & $-18,739$ & 0,348 & 2429,79 & 96,63 & 26,78 & 0,646 & 6253,15 & 0,009 & 0,000 & 2,108 \\
\hline dez-01 & \begin{tabular}{|l|}
$-14,946$ \\
\end{tabular} & $-1,871$ & 0,148 & 436,05 & 3,75 & 6,66 & 0,024 & 38,46 & 0,007 & 0,000 & 1,067 \\
\hline mar-02 & $-13,281$ & $-1,148$ & 0,146 & 407,30 & 2,12 & 10,28 & 0,023 & 22,00 & 0,009 & 0,000 & 2,149 \\
\hline jun- 02 & $-11,233$ & $-0,706$ & 0,140 & 349,88 & 1,93 & 11,28 & 0,023 & 20,30 & 0,007 & 0,000 & 1,268 \\
\hline set- 02 & \begin{tabular}{|l|}
$-10,499$ \\
\end{tabular} & $-0,596$ & 0,138 & 327,37 & 2,07 & 7,63 & 0,023 & 20,91 & 0,007 & 0,000 & 1,381 \\
\hline dez-02 & $-11,447$ & $-0,799$ & 0,140 & 353,44 & 2,80 & 11,42 & 0,023 & 29,33 & 0,010 & 0,000 & 2,938 \\
\hline mar- 03 & $-16,713$ & $-1,582$ & 0,157 & 524,95 & 10,70 & 81,78 & 0,036 & 151,92 & 0,012 & 0,000 & 3,786 \\
\hline jun-03 & $-118,01$ & 10,313 & 0,887 & 7824,13 & 170,89 & 1093,2 & 0,994 & 9733,58 & 0,011 & 0,000 & 3,308 \\
\hline set-03 & $|-124,99|$ & 11,122 & 0,910 & 8057,16 & 166,81 & 1078,6 & 0,992 & 9719,89 & 0,007 & 0,000 & 1,339 \\
\hline dez- 03 & $\mid-166,73$ & 16,163 & 0,980 & 8747,28 & 154,44 & 1044,6 & 0,986 & 9658,35 & 0,010 & 0,000 & 2,538 \\
\hline mar-04 & \begin{tabular}{|l|}
$-159,49$ \\
\end{tabular} & 17,357 & 0,976 & 8707,51 & 160,99 & 1007,0 & 0,989 & 9689,78 & 0,010 & 0,000 & 2,714 \\
\hline jun-04 & $-57,47$ & 5,724 & 0,483 & 3783,61 & 72,86 & 105,92 & 0,398 & 3775,51 & 0,009 & 0,000 & 2,262 \\
\hline set- 04 & $-49,94$ & 5,208 & 0,418 & 3134,11 & 76,08 & 111,10 & 0,435 & 4147,97 & 0,008 & 0,000 & 1,773 \\
\hline dez-04 & $-4,443$ & 0,544 & 0,121 & 163,25 & 2,77 & 0,58 & 0,023 & 26,59 & 0,013 & 0,000 & 3,983 \\
\hline mar-05 & $-2,920$ & 0,394 & 0,115 & $\mathbf{1 0 5 , 8 8}$ & 3,25 & 0,50 & 0,024 & 31,61 & 0,013 & 0,000 & 4,086 \\
\hline jun- 05 & $-1,475$ & 0,258 & 0,110 & 53,92 & 3,08 & 0,51 & 0,023 & 29,77 & 0,010 & 0,000 & 2,695 \\
\hline set-05 & 0,312 & 0,106 & 0,104 & $-6,86$ & 0,02 & 0,92 & 0,020 & $-0,29$ & 0,010 & 0,000 & 2,879 \\
\hline
\end{tabular}

* Os valores dos IRS2, IRS4 e IRS5 estão multiplicados por 10000, 10000 e 1000000, respectivamente. 
4. Rússia - set/1995 a dez/2004

\begin{tabular}{|c|c|c|c|c|c|c|c|c|c|c|c|}
\hline eríodo & Indicas & es & Eq. 2 & IRS2 & Indica & es & Eq. 4 & RS4 & Indicador & Eq. 5 & IRS 5 \\
\hline & MROE $\Lambda$ & MIRCRE & & 0,10478 & DROE & DIRTJ & & 0,02048 & DCAOC & & 0,0003 \\
\hline set-95 & $-0,075$ & 0,022 & 1049 & ,434 & 0,02 & 27,21 & 0,0210 & 5.035 & 0,005 & 0,0003 & 0,248 \\
\hline dez-95 & $-0,076$ & 22 & 1049 & 428 & 0,02 & 65,54 & 218 & & 005 & 0003 & 15 \\
\hline mar-96 & $-0,071$ & 0,020 & 0,1049 & 1,250 & 0,02 & 67,25 & 0,0218 & & 005 & 0003 & 120 \\
\hline jun-96 & $-0,053$ & 19 & 048 & 0,644 & 0,03 & 68,34 & 0,0219 & & 004 & 0003 & $-0,101$ \\
\hline set-96 & $-0,020$ & 15 & 047 & 24 & 0,03 & 90,37 & 223 & & 002 & 0003 & 329 \\
\hline dez-96 & $-0,004$ & 11 & 1047 & & 0,03 & 37,89 & 0,0212 & 7,299 & 0,003 & 0,0003 & $-0,708$ \\
\hline mar-97 & 0,012 & 0,010 &, 1046 & $-1,676$ & 0,02 & 32,77 & 0,0211 & 141 & 004 & 0,0003 & 331 \\
\hline $1-97$ & 0,015 & 10 & 1046 & & 0,01 & 7,55 & 206 & & 006 & 0,0003 & 000 \\
\hline set-97 & 0,011 & 0,014 &, 1046 & & 0,01 & 4,30 & 0,0205 & 67 & 007 & 0003 & ,491 \\
\hline dez-97 & 0,014 & 0,020 & 0,1046 & 56 & 0,01 & 6,72 & 0,0206 & 59 & 010 & 0003 & 678 \\
\hline mar-98 & 0,017 & 44 & 1047 & $-0,468$ & 0,01 & 5,49 & 0,0205 & 546 & 024 & 0003 & ,734 \\
\hline jun-98 & 010 & 75 & 049 & 555 & 0,02 & 7,55 & 206 & 060 & 030 & 0,0003 & 875 \\
\hline set-98 & $-0,062$ & & 0,1054 & & 0,13 & & 0,0210 & & 041 & 0003 & \\
\hline $\mathrm{z}-98$ & $-0,147$ & & 0,1059 & & 0,15 & 20,37 & 210 & & 35 & 0003 & \\
\hline r-99 & $-0,261$ & & 063 & & 0,14 & 15,46 & 209 & 04 & 30 & 003 & 581 \\
\hline jun-99 & $-0,324$ & 27 & 0,1065 & 17,082 & 0,06 & 14,46 & 0,0208 & 84 & 14 & 0003 & 801 \\
\hline set-99 & $-0,309$ & 23 & 0,1060 & 12,497 & 0,08 & 13,45 & 0,0208 & 999 & 005 & 0,0003 & 0,151 \\
\hline dez-99 & $-0,238$ & 64 & 056 & 82 & 0,03 & 15,50 & 208 & 750 & 11 & 003 & ,262 \\
\hline mar-00 & & & 55 & & 0,02 & 1,87 & 05 & & 18 & 0003 & 767 \\
\hline jun-00 & & & 56 & & 0,02 & 1,67 & 05 & & 29 & 003 & 206 \\
\hline set-00 & $-0,176$ & 26 & 056 & 74 & 0,02 & 0,70 & 204 & & 27 & 003 & 404 \\
\hline dez- 00 & $-0,162$ & 38 & 056 & 20 & 0,02 & 0,68 & 204 & & 19 & 003 & 301 \\
\hline mar-01 & $-0,151$ & 0,120 & 0,1055 & 04 & 0,02 & 0,66 & 204 & 88 & 06 & 003 & 780 \\
\hline jun-01 & 40 & 86 & 054 & 10 & 0,01 & 0,66 & 204 & 462 & 05 & 003 & 303 \\
\hline set-01 & & & & & 0,01 & 0,46 & 204 & 169 & 02 & 0003 & $-1,021$ \\
\hline dez-01 & $-0,116$ & & 051 & & 0,02 & 1,23 & 205 & & 08 & 003 & 666 \\
\hline $\mathrm{r}-02$ & $-0,096$ & & 50 & & 0,03 & 34 & 205 & 8 & 008 & 0,0003 & 1,543 \\
\hline jun-02 & $-0,075$ & 37 & 0,1050 & 35 & 0,03 & 1,50 & 205 & 10 & 07 & 003 & 325 \\
\hline set-02 & $-0,056$ & 37 & 0,1049 & 33 & 0,02 & 0,55 & 204 & 16 & 02 & 0003 & 95 \\
\hline dez-02 & $-0,044$ & & 0,1049 & 0,901 & 0,01 & 6,78 & 0,0206 & 0,764 & 004 & 0003 & $-0,133$ \\
\hline mar-03 & $-0,010$ & & 0,1047 & $-0,319$ & 0,05 & 8,24 & 0,0206 & 1,494 & 004 & 0,0003 & $-0,140$ \\
\hline jun-03 & 0,020 & & 0,1046 & $-1,468$ & 0,06 & 7,32 & 0,0206 & 1,337 & 002 & 0,0003 & $-1,009$ \\
\hline set-03 & 0,051 & 0,020 & 0,1045 & $-2,434$ & 0,05 & 0,96 & 0,0205 & $-0,008$ & 001 & 0,0003 & $-1,509$ \\
\hline dez-03 & 0,088 & 0,021 & 0,1044 & $-3,506$ & 0,01 & 8,32 & 0,0206 & 1,136 & 003 & 0,0003 & 574 \\
\hline mar-04 & 0,105 & 21 & 0,1044 & 14 & 0,03 & 9,41 & 0,0206 & 16 & 003 & 0,0003 & $-0,592$ \\
\hline jun-04 & 0,117 & 0,026 & 0,1044 & $-4,169$ & 0,02 & 7,81 & 0,0206 & 1,128 & 0,004 & 0,0003 & $-0,283$ \\
\hline set-04 & 0,132 & 0,044 & 0,1044 & $-3,910$ & 0,02 & 0,26 & 0,0204 & $-0,447$ & 0,008 & 0,0003 & 1,676 \\
\hline dez-04 & 0,148 & 0,061 & 0,1044 & $-3,745$ & 0,02 & 0,86 & 0,0204 & $-0,309$ & 0,009 & 0,0003 & 2,020 \\
\hline
\end{tabular}


5. Islândia - dez/1993 a dez/2001

\begin{tabular}{|c|c|c|c|c|c|c|c|c|c|c|c|}
\hline 0 & \multicolumn{2}{|c|}{ Indicadores } & q. 2 & $\mathrm{RS} 2$ & \multicolumn{2}{|c|}{ Indicadores } & q. 4 & RS4 & ndi & q. 5 & RS 5 \\
\hline & MROE & MIRCRE & & 0,10478 & DROE & DIRTJ & & 0,02048 & DCAOC & & 0003 \\
\hline 3 & $-0,022$ & & & 9008 & 0,087 & 37 & $0,0<0$ & 5621 & 0,0097 & & ,5577 \\
\hline & & & & & 0,08 & & & & & & \\
\hline dez-95 & $-0,019$ & 0 & 055 & 6,7867 & 0,088 & 68 & 206 & 71 & 83 & 0,00026 & 8751 \\
\hline dez-96 & 043 & 0 & 052 & 76 & 0,034 & $\frac{1}{4}$ & 6 & & & 0, & 60 \\
\hline dez-97 & & & 50 & & 0,027 & 90 & 205 & & & 26 & 1476 \\
\hline dez-98 & 0,091 & 0,126 & 1048 & 0,5378 & 0,021 & 1,077 & 0205 & & 23 & 0,00025 & 0280 \\
\hline dez-99 & & 090 & 046 & 508 & 0,023 & 227 & 205 & 085 & 016 & 0,00025 & 3542 \\
\hline dez- 00 & & & & &, 021 & 65 & & & & & ,9688 \\
\hline dez-01 & 0,112 & 0,030 & 0,1044 & $-3,8847$ & 0,022 & 5,242 & 0,0205 & 0,5886 & 0,0010 & 0,00025 & $-1,6444$ \\
\hline
\end{tabular}

* Os valores dos IRS2, IRS4 e IRS5 estão multiplicados por 10000, 10000 e 1000000, respectivamente.

** Dados anuais 
6. Tailândia - jun/1996 a dez/2004

\begin{tabular}{|c|c|c|c|c|c|c|c|c|c|c|c|}
\hline \multirow[t]{2}{*}{ Período } & \multicolumn{2}{|c|}{ Indicadores } & Eq. 2 & \multirow{2}{*}{\begin{tabular}{|c|} 
IRS2 \\
$\mathbf{0 , 1 0 4 7 8}$ \\
\end{tabular}} & \multicolumn{2}{|c|}{ Indicadores } & \multirow[t]{2}{*}{ Eq. 4} & \multirow{2}{*}{$\begin{array}{c}\text { IRS4 } \\
0,02048 \\
\end{array}$} & \multirow{2}{*}{\begin{tabular}{|l|} 
Indicad \\
DCAOC
\end{tabular}} & \multirow[t]{2}{*}{ Eq. 5} & \multirow{2}{*}{\begin{tabular}{|c|} 
IRS 5 \\
0,00026 \\
\end{tabular}} \\
\hline & MROE & MIRCRE & & & DROE & DIRTJ & & & & & \\
\hline jun-96 & 0,047 & 0,321 & 0,1057 & 0,0096 & 0,015 & 0,274 & 0,0204 & $-0,4710$ & 0,0293 & 0,00027 & 0,0012 \\
\hline set-96 & 0,074 & 0,484 & 0,1063 & 0,0152 & 0,040 & 0,965 & 0,0205 & $-0,1037$ & 0,0423 & 0,00027 & 0,0019 \\
\hline dez-96 & 0,080 & 0,604 & 0,1068 & 0,0199 & 0,036 & 1,440 & 0,0205 & $-0,0456$ & 0,0515 & 0,00028 & 0,0024 \\
\hline mar-97 & 0,067 & 2,220 & 0,1135 & 0,0868 & 0,056 & 1,359 & 0,0205 & & 0,3335 & 0,00048 & 0,0221 \\
\hline jun-97 & 0,066 & 4,039 & 0,1214 & 0,1660 & 0,056 & 4,143 & 0,0205 & 0,6793 & 0,4052 & 0,00055 & 0,0290 \\
\hline set-97 & 0,047 & 5,755 & 0,1293 & 0,2456 & 0,043 & 7,411 & 0,0206 & 1,2167 & 0,3840 & 0,00052 & 0,0269 \\
\hline dez-97 & $-0,016$ & 10,125 & 0,1517 & 0,4693 & 0,086 & 8,517 & 0,0207 & 1,8401 & 0,9356 & 0,00149 & 0,1232 \\
\hline mar-98 & $-0,036$ & 14,535 & 0,1772 & 0,7243 & 0,093 & 8,392 & 0,0207 & 1,8843 & 1,5583 & 0,00482 & 0,4562 \\
\hline jun-98 & $-0,095$ & 20,445 & 0,2167 & & 0,089 & 5,490 & 0,0206 & & 2,2312 & 0,01700 & 6741 \\
\hline set-98 & $-0,112$ & 25,176 & 0,2524 & 1,4759 & 0,062 & 4,668 & 0,0206 & & 2,102 & 0,0134 & 1,3112 \\
\hline dez-98 & $-0,120$ & 27,970 & 0,2752 & 1,7041 & 0,068 & 5,327 & 0,0206 & 1,0322 & 2,561 & 0,0313 & 3,1019 \\
\hline mar-99 & $-0,115$ & 27,581 & 0,2719 & 1,6714 & 0,070 & 5,366 & 0,0206 & 1,0591 & 2,064 & 0,0125 & 1,2197 \\
\hline jun-99 & $-0,106$ & 23,974 & 0,2429 & 1,3815 & 0,064 & 5,578 & 0,0206 & 1,0426 & 1,732 & 0,0067 & 0,6423 \\
\hline set-99 & $-0,111$ & 19,351 & 0,2090 & 1,0426 & 0,057 & 8,465 & 0,0206 & 1,5643 & 0,839 & 0,0012 & 0,0983 \\
\hline dez-99 & $-0,099$ & & 0,1733 & & & & 0,0206 & & 0,752 & 0,0011 & 0796 \\
\hline mar-00 & $-0,087$ & & 0,1496 & & 0,053 & 3,269 & 0,0205 & & 0,594 & 0,0008 & 0525 \\
\hline jun-00 & $-0,071$ & 9,231 & 0,1472 & 0,4238 & 0,042 & 0,863 & 0,0205 & $-0,1092$ & 1,300 & 0,0030 & $\mathbf{0 , 2 7 0 5}$ \\
\hline set-00 & $-0,034$ & 15,415 & 0,1827 & 0,7787 & 0,091 & 0,348 & 0,0205 & 0,2397 & 2,427 & 0,0244 & 2,4183 \\
\hline dez-00 & 0,025 & 22,791 & 0,2332 & 1,2837 & 0,083 & 0,187 & 0,0205 & 0,1320 & 2,707 & 0,0408 & 4,0554 \\
\hline mar-01 & 0,036 & 25,760 & 0,2561 & 1,5134 & 0,077 & 0,204 & 0,0205 & 0,0861 & 1,335 & 0,0032 & 0,2908 \\
\hline jun-01 & 0,087 & 26,360 & 0,2606 & & 0,045 & 0,135 & 0,0205 & $-0,2216$ & 1,295 & 0,0029 & 0,2676 \\
\hline set-01 & 0,063 & & 0,2327 & & 0,052 & & 0,0205 & -0 , & 1,296 & 0,0029 & 0,2681 \\
\hline dez-01 & 0,037 & 17,416 & 0,1952 & & 0,052 & & 0,0205 & & 1,148 & 0,0022 & 1967 \\
\hline mar-02 & 0,039 & 14,690 & 0,1778 & 0,7303 & 0,052 & & 0,0205 & & 0,553 & 0,0007 & 0,0466 \\
\hline jun-02 & 0,013 & 14,226 & 0,1751 & 0,7032 & 0,009 & 0,023 & 0,0204 & $-0,5767$ & 1,295 & 0,0029 & 0,2678 \\
\hline set-02 & 0,013 & 13,612 & 0,1714 & 0,6662 & 0,009 & 0,037 & 0,0204 & $-0,5739$ & 1,352 & 0,0033 & 0,3010 \\
\hline dez-02 & 0,013 & 12,400 & 0,1643 & 0,5951 & 0,008 & 0,096 & 0,0204 & $-0,5699$ & 0,932 & 0,0015 & 0,1222 \\
\hline mar-03 & 0,014 & 11,300 & 0,1580 & 0,5327 & 0,009 & 0,108 & 0,0204 & $-0,5650$ & 0,221 & 0,0004 & 0,0130 \\
\hline jun-03 & 0,018 & 7,971 & 0,1403 & & 0,014 & 0,075 & 0,0204 & $-0,5227$ & 0,219 & 0,0004 & 0,0128 \\
\hline set-03 & 0,014 & 4,298 & 0,1227 & 0,1794 & 0,016 & & 0,0204 & & 0,115 & 0,0003 & 0,0060 \\
\hline dez-03 & 0,018 & 2,566 & 0,1151 & 0,1030 & 0,014 & 0,120 & 0,0204 & $-0,5129$ & 0,351 & 0,0005 & 0,0237 \\
\hline mar-04 & 0,016 & 2,789 & 0,1161 & 0,1127 & 0,014 & 0,114 & 0,0204 & $-0,5105$ & 0,321 & 0,0005 & 0,0210 \\
\hline jun-04 & 0,005 & 3,332 & 0,1184 & 0,1367 & 0,008 & 0,123 & 0,0204 & $-0,5670$ & 0,420 & 0,0006 & $\mathbf{0 , 0 3 0 5}$ \\
\hline set-04 & 0,016 & 4,260 & 0,1225 & $\mathbf{0 , 1 7 7 6}$ & 0,018 & 0,129 & 0,0204 & $-0,4722$ & 0,450 & 0,0006 & 0,0338 \\
\hline dez-04 & 0,006 & 5,143 & 0,1266 & 0,2184 & 0,025 & 0,182 & 0,0204 & $-0,3968$ & 0,651 & 0,0009 & 0,0614 \\
\hline
\end{tabular}

* Os valores dos IRS2, IRS4 e IRS5 estão multiplicados por 10, 10000 e 100, respectivamente. 
7. Suécia - dez/1990 a dez/2000

\begin{tabular}{|c|c|c|c|c|c|c|c|c|c|c|c|}
\hline lo & \multicolumn{2}{|c|}{ Indicadores } & 2 & IRS2 & \multicolumn{2}{|c|}{ Indicadores } & 4 & RS4 & Indicad & Eq. 5 & \begin{tabular}{|l} 
IRS 5 \\
\end{tabular} \\
\hline & MROE & MIRCRE & & 0,10478 & DROE & DIRTJ & & 0,02048 & DCAOC & & 0,0003 \\
\hline dez-90 & 0,043 & 0,043 & 0,10465 & $-0,1304$ & 0,016 & 17,315 & 0,0208 & 2,9702 & 0,0060 & 0,00026 & 0,0794 \\
\hline dez-91 & 0,157 & 32 & 51 & & & & 0,0208 & & & 0,00027 & \\
\hline dez-92 & & & & & & & 0,0208 & & & 0,00027 & \\
\hline dez-93 & 0,117 & 0,480 & 0,1062 & 1,3791 & 0,155 & 6,550 & 0,0207 & 2,0859 & 238 & 0,00027 & 0,9573 \\
\hline dez-94 & 0,149 & 0,585 & 0,1065 & 1,7010 & 0,146 & 7,836 & 0,0207 & 2,2650 & 245 & 0,00027 & 0,9900 \\
\hline dez-95 & 0,098 & 0,488 & 0,1063 & 1,4687 & 0,072 & 4,143 & 0,0206 & 0,8276 & 128 & 0,00026 & 0,4085 \\
\hline dez-96 & 0,135 & 0,337 & 0,1055 & 0,7535 & 0,075 & 12,871 & 0,0207 & 2,6201 & 0,0054 & 0,00026 & 0,0482 \\
\hline dez-97 & 0,153 & 0,213 & 0,1050 & & & & 0,0207 & & & 0,00025 & $-0,1273$ \\
\hline dez-98 & 0,149 & 0,091 & 0,1045 & $-0,2$ & 0,045 & 9,369 & 0,0206 & & 0,0013 & 0,00025 & -0 \\
\hline dez-99 & 0,136 & & 0,1044 & & & & 0,0205 & & 0,001 & 0,0003 & $-0,1485$ \\
\hline dez-00 & 0,124 & 0,023 & 0,1043 & $-0,4509$ & 0,028 & 4,545 & 0,0205 & 0,5016 & 0,001 & 0,0003 & $-0,1519$ \\
\hline
\end{tabular}

* Os valores dos IRS2, IRS4 e IRS5 estão multiplicados por 1000, 10000 e 100000, respectivamente.

** Dados anuais. 
8. Reino Unido - dez/1990 a dez/2001

\begin{tabular}{|c|c|c|c|c|c|c|c|c|c|c|c|}
\hline \multirow[t]{2}{*}{ Período } & \multicolumn{2}{|c|}{ Indicadores } & & IRS2 & \multicolumn{2}{|c|}{ Indicadores } & & & & & \multirow{2}{*}{$\begin{array}{c}\text { IRS } 5 \\
\mathbf{0 , 0 0 0 3}\end{array}$} \\
\hline & MROE & MIRC & & 0,10478 & DROE & DIRTJ & & & & & \\
\hline & & & & & & & 200 & & & 0,00026 & 1,6566 \\
\hline-91 & & & & & & & & & & & \\
\hline & & & & & & & & & & & \\
\hline & & & & & & & & & & & \\
\hline dez-94 & & & & & & & & & & 26 & \\
\hline & & & & & & & 205 & & & 026 & \\
\hline dez-96 & & & & & & & 205 & & & 026 & \\
\hline & & & & & & & 205 & & & 0,00025 & \\
\hline & & & & & & & & & & & \\
\hline dez-99 & & & & & & & & & & & \\
\hline & & & & & & & & & & & \\
\hline dez-01 & 0,174 & 0,013 & 0,1041 & $-0,6409$ & 0,031 & 0,686 & 0,0205 & $-0,2433$ & 0,0004 & 0,00025 & $-1,9392$ \\
\hline
\end{tabular}

* Os valores dos IRS2, IRS4 e IRS5 estão multiplicados por 1000, 10000 e 1000000, respectivamente.

** Dados anuais. 
9. Austrália - dez/1989 a dez/2001

\begin{tabular}{|c|c|c|c|c|c|c|c|c|c|c|c|}
\hline \multirow[t]{2}{*}{ Período } & \multicolumn{2}{|c|}{ Indicadores } & 2 & \multirow{2}{*}{\begin{tabular}{|c|} 
IRS2 \\
0,10478 \\
\end{tabular}} & \multicolumn{2}{|c|}{ Indicadores } & \multirow[t]{2}{*}{ Eq. 4} & \multirow{2}{*}{\begin{tabular}{|c|} 
IRS4 \\
0,02048 \\
\end{tabular}} & \multirow{2}{*}{\begin{tabular}{|l|} 
Indicador \\
DCAOC \\
\end{tabular}} & \multirow[t]{2}{*}{ Eq. 5} & \multirow{2}{*}{\begin{tabular}{|l|} 
IRS 5 \\
0,0003 \\
\end{tabular}} \\
\hline & MROE & MIR & & & DROE & DIRTJ & & & & & \\
\hline-89 & & & 4 & & 03 & & 04 & & ח & & (2) \\
\hline $\mathrm{de}$ & & & & & 21 & & 4 & & & & \\
\hline-91 & & & & & 2 & & & & & & \\
\hline 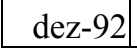 & & & & & 32 & & 05 & & & & \\
\hline C2-93] & & & & & & & 05 & & & 20 & \\
\hline dez-94 & & & & & 35 & & 205 & & & & \\
\hline dez-95 & & & 47 & & 40 & 1 & 06 & & & 然 & \\
\hline 50 & & & & & & & & & & & \\
\hline & & & & & & & & & & 0025 & \\
\hline d & & & & & & & & & 05 & 0,0 & \\
\hline de & 90 & 0 , & & & ? & 7 & 04 & & 04 & 25 & \\
\hline dez-00 & & & & & & & & & & 0,00025 & \\
\hline dez-01 & 0,089 & 0,004 & 0,1044 & $-0,4203$ & 0,003 & 2,373 & 0,0205 & $-0,1606$ & 0,0005 & 0,00025 & $-1,875$ \\
\hline
\end{tabular}

* Os valores dos IRS2, IRS4 e IRS5 estão multiplicados por 1000, 10000 e 1000000, respectivamente.

** Dados anuais. 
10. Estados Unidos - dez/1989 a dez/2001

\begin{tabular}{|c|c|c|c|c|c|c|c|c|c|c|c|}
\hline eríodo & & ores & Eq. 2 & IRS2 & Indic & dores & Eq. 4 & IRS4 & Indice & Eq. 5 & IRS 5 \\
\hline & ИROE & MIRC & & 0,1047 & $\mathrm{ROE}$ & DIRTJ & & $\mathbf{0 , 0 2 0 4}$ & DCAOC & & 0,000 \\
\hline 89 & 036 & & 0, & & 0,036 & & & & & & 5235 \\
\hline & & & & & & & & & & & \\
\hline & & & & & & & & & & & \\
\hline & & & & & & & & & & & \\
\hline & & & 0 & & 31 & & & & & & $-0,527$ \\
\hline & & & & & & & & & & & \\
\hline & & & & & & & & & & & 46 \\
\hline & & 6 & 0 & & & & & & & & \\
\hline & & & & & & & 0, & & & & 806 \\
\hline & & & & & & & t. & & & & 838 \\
\hline & & & & & & & & & & 0,0 & 008 \\
\hline & & & & & & & & & & & 321 \\
\hline & & & 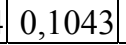 & $-0,5220$ & | & I0, & - & $-0,5684$ &, 00 &, 00025 & $\mid-1,2$ \\
\hline
\end{tabular}

* Os valores dos IRS2, IRS4 e IRS5 estão multiplicados por 1000, 10000 e 1000000, respectivamente.

** Dados anuais. 
ANEXOS

ANEXO A: ESTATÍSTICA DESCRITIVA

ANEXO B: MATRIZ DE CORRELAÇÃO DE PEARSON

ANEXO C: RESULTADOS DA ANÁLISE FATORIAL

ANEXO D: RESULTADO DA REGRESSÃO LOGÍSTICA - 10 COEFICIENTES

ANEXO E: RESULTADO DA REGRESSÃO LOGÍSTICA - 10 MÉDIAS

ANEXO F: RESULTADO DA REGRESSÃO LOGÍSTICA - 10 DESVIOS-PADRÃO

ANEXO G: RESULTADO DA REGRESSÃO LOGÍSTICA - CROE E CIRTJ

ANEXO H: RESULTADO DA REGRESSÃO LOGÍSTICA - MROE E MIRCRE

ANEXO I: RESULTADO DA REGRESSÃO LOGÍSTICA - MROE E MIRTJ

ANEXO J: RESULTADO DA REGRESSÃO LOGÍSTICA - DROE E DIRTJ

ANEXO K: RESULTADO DA REGRESSÃO LOGÍSTICA - DCAOC

ANEXO L: RESULTADO DA REGRESSÃO LOGÍSTICA - MROE 
ANEXO A: ESTATÍSTICA DESCRITIVA

\begin{tabular}{|c|c|c|c|c|c|c|}
\hline & $\mathrm{N}$ & Mínimo & Máximo & Média & Desvio-padrão & $\begin{array}{l}\text { Coeficiente } \\
\text { de variação }\end{array}$ \\
\hline CATPL & 32 & 3 & 163 & 52,25 & 39,81 & 0,76 \\
\hline CALDT & 32 & 14 & 1.225 & 184,66 & 251,91 & 1,36 \\
\hline CCAOC & 32 & 37 & 2.963 & 289,50 & 516,33 & 1,78 \\
\hline CNOPPL & 32 & 50 & 3.906 & 495,41 & 799,13 & 1,61 \\
\hline CROE & 32 & 12 & 26.771 & $2.194,50$ & $5.047,61$ & 2,30 \\
\hline CIRFX & 32 & 95 & 7.382 & 964,75 & $1.463,69$ & 1,52 \\
\hline CIRTJ & 32 & 138 & 944 & 379,34 & 204,87 & 0,54 \\
\hline CIRCRE & 32 & 51 & 763 & 373,22 & 204,97 & 0,55 \\
\hline CIRLIQ & 32 & 88 & 4.926 & 465,00 & 856,20 & 1,84 \\
\hline CIRATPIB & 32 & 17 & 209 & 83,97 & 51,81 & 0,62 \\
\hline MATPL & 32 & 3.205 & 24.520 & $15.112,97$ & $5.918,57$ & 0,39 \\
\hline MALDT & 32 & -204 & 1.454 & 354,91 & 371,71 & 1,05 \\
\hline MCAOC & 32 & 0 & 514 & 67,47 & 102,48 & 1,52 \\
\hline \begin{tabular}{|l} 
MNOPPL \\
\end{tabular} & 32 & -4.065 & 575 & $-710,09$ & $1.023,06$ & $-1,44$ \\
\hline MROE & 32 & -115 & 240 & 66,38 & 77,62 & 1,17 \\
\hline MIRFX & 32 & -13.170 & 2.013 & $-3.136,22$ & $3.594,00$ & $-1,15$ \\
\hline MIRTJ & 32 & 174 & 34.616 & $9.877,25$ & $8.271,63$ & 0,84 \\
\hline MIRCRE & 32 & 17 & 1.006 & 161,72 & 213,15 & 1,32 \\
\hline MIRLIQ & 32 & -713 & 25.012 & $1.657,81$ & $4.403,62$ & 2,66 \\
\hline MIRATPIB & 32 & 405 & 8.405 & $2.711,38$ & $1.970,52$ & 0,73 \\
\hline DATPL & 32 & 38 & 2.731 & 838,28 & 744,00 & 0,89 \\
\hline DALDT & 32 & 1 & 304 & 48,19 & 67,92 & 1,41 \\
\hline DCAOC & 32 & 0 & 71 & 9,97 & 16,35 & 1,64 \\
\hline DNOPPL & 32 & 11 & 417 & 162,31 & 110,16 & 0,68 \\
\hline DROE & 32 & 1 & 219 & 36,97 & 50,82 & 1,37 \\
\hline DIRFX & 32 & 89 & 8.934 & $1.895,47$ & $2.015,02$ & 1,06 \\
\hline DIRTJ & 32 & 89 & 14.551 & $3.953,56$ & $4.143,86$ & 1,05 \\
\hline DIRCRE & 32 & 2 & 415 & 59,44 & 92,69 & 1,56 \\
\hline DIRLIQ & 32 & 13 & 29.279 & $1.278,91$ & $5.154,37$ & 4,03 \\
\hline DIRATPIB & 32 & 22 & 775 & 207,94 & 197,91 & 0,95 \\
\hline \multicolumn{6}{|c|}{ COEFICIENTE DE VARIAÇÃO MÉDIO (SOMATÓRIO / 32) = } & 1,15 \\
\hline
\end{tabular}

Fonte: Saída SPSS v.10.0, adaptada pelo autor. 


\section{ANEXO B: MATRIZ DE CORRELAÇÃO DE PEARSON}

Coeficientes de variação

\begin{tabular}{|l|l|l|l|l|l|l|l|l|l|l|}
\hline INDICADOR & CATPL & CALDT & CCAOC & CNOPPL & CROE & CIRFX & CIRTJ & CIRCRE & CIRLIQ & CIRATPIB \\
\hline
\end{tabular}

\begin{tabular}{|lr|r|r|r|r|r|r|r|r|r|r|}
\hline CATPL & 1 & $-0,132$ & 0,299 & 0,254 & 0,079 & $\mathbf{0 , 4 8}$ & 0,023 & $-0,201$ & $-0,139$ & 0,065 \\
\hline & & 0,471 & 0,096 & 0,16 & 0,667 & $\mathbf{0 , 0 0 5}$ & 0,899 & 0,27 & 0,447 & 0,722 \\
\hline CALDT & $-0,132$ & 1 & $-0,052$ & $-0,155$ & $-0,121$ & $-0,066$ & $\mathbf{0 , 5 6 5}$ & $-0,031$ & $\mathbf{0 , 6 5 6}$ & $-0,12$ \\
\hline & 0,471 & & 0,778 & 0,398 & 0,508 & 0,72 & $\mathbf{0 , 0 0 1}$ & 0,865 & $\mathbf{0} *$ & 0,511 \\
\hline CCAOC & 0,299 & $-0,052$ & 1 & $-0,069$ & $-0,155$ & $-0,128$ & $-0,222$ & 0,307 & $-0,061$ & 0,175 \\
\hline CNOPPL & 0,096 & 0,778 & & 0,707 & 0,397 & 0,484 & 0,222 & 0,087 & 0,741 & 0,339 \\
\hline & 0,254 & $-0,155$ & $-0,069$ & 1 & $-0,108$ & $\mathbf{0 , 6 0 5}$ & $-0,026$ & $-0,088$ & $-0,11$ & $-0,042$ \\
\hline CROE & 0,16 & 0,398 & 0,707 & & 0,557 & $\mathbf{0} *$ & 0,889 & 0,633 & 0,55 & 0,818 \\
\hline & 0,08 & $-0,12$ & $-0,16$ & $-0,11$ & 1,00 & $-0,04$ & 0,03 & $-0,29$ & $-0,05$ & 0,27 \\
\hline CIRFX & 0,67 & 0,51 & 0,40 & 0,56 & & 0,85 & 0,89 & 0,10 & 0,77 & 0,14 \\
\hline & 0,48 & $-0,07$ & $-0,13$ & 0,61 & $-0,04$ & 1,00 & 0,21 & $-0,09$ & $-0,08$ & 0,15 \\
\hline CIRTJ & 0,01 & 0,72 & 0,48 & 0,00 & 0,85 & & 0,26 & 0,63 & 0,68 & 0,40 \\
\hline & 0,02 & 0,57 & $-0,22$ & $-0,03$ & 0,03 & 0,21 & 1,00 & 0,13 & 0,25 & 0,00 \\
\hline CIRCRE & 0,90 & 0,00 & 0,22 & 0,89 & 0,89 & 0,26, & 0,49 & 0,17 & 0,99 \\
\hline & $-0,20$ & $-0,03$ & 0,31 & $-0,09$ & $-0,29$ & $-0,09$ & 0,13 & 1,00 & $-0,20$ & $-0,10$ \\
\hline CIRLIQ & 0,27 & 0,87 & 0,09 & 0,63 & 0,10 & 0,63 & 0,49 & & 0,28 & 0,60 \\
\hline & $-0,14$ & 0,66 & $-0,06$ & $-0,11$ & $-0,05$ & $-0,08$ & 0,25 & $-0,20$ & 1,00 & $-0,20$ \\
\hline CIRATPIB & 0,45 & 0,00 & 0,74 & 0,55 & 0,77 & 0,68 & 0,17 & 0,28 & & 0,26 \\
\hline & 0,07 & $-0,12$ & 0,18 & $-0,04$ & 0,27 & 0,15 & 0,00 & $-0,10$ & $-0,20$ & 1,00 \\
\hline N & 0,72 & 0,51 & 0,34 & 0,82 & 0,14 & 0,40 & 0,99 & 0,60 & 0,26, & 32 \\
\hline
\end{tabular}

* Correlação significativa ao nível de significância de 1\% (2-tailed)

Médias

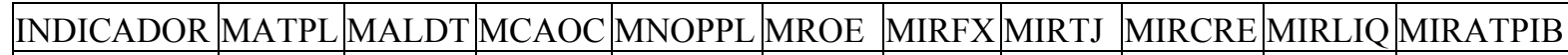

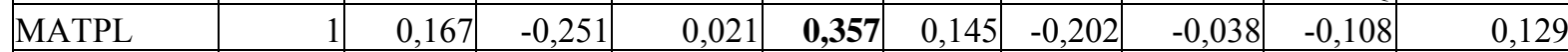

\begin{tabular}{|lr|r|r|r|r|r|r|r|r|r|r|}
\hline & & 0,362 & 0,167 & 0,91 & $\mathbf{0 , 0 4 5} * *$ & 0,428 & 0,268 & 0,835 & 0,557 & 0,481 \\
\hline MALDT & 0,167 & 1 & 0,127 & 0,009 & $\mathbf{- 0 , 4 0 2}$ & $-0,082$ & 0,339 & 0,152 & $-0,257$ & $\mathbf{0 , 4 7 2}$ \\
\hline & 0,362 & & 0,489 & 0,96 & $\mathbf{0 , 0 2 3} * *$ & 0,655 & 0,058 & 0,407 & 0,156 & $\mathbf{0 , 0 0 6} *$ \\
\hline MCAOC & $-0,251$ & 0,127 & 1 & 0,016 & $\mathbf{- 0 , 3 9 3}$ & $-0,274$ & $\mathbf{0 , 4 1 8}$ & $\mathbf{0 , 8 2 3}$ & 0,245 & $-0,031$ \\
\hline & 0,167 & 0,489 & & 0,932 & $\mathbf{0 , 0 2 6} * *$ & 0,128 & $\mathbf{0 , 0 1 7} *$ & $\mathbf{0} *$ & 0,176 & 0,866 \\
\hline MNOPPL & 0,021 & 0,009 & 0,016 & 1 & $-0,063$ & $\mathbf{0 , 7 8 6}$ & $-0,133$ & $-0,025$ & $-0,181$ & $-0,135$ \\
\hline MROE & 0,91 & 0,96 & 0,932 & & 0,732 & $\mathbf{0} *$ & 0,467 & 0,893 & 0,321 & 0,461 \\
\hline & 0,357 & $-0,402$ & $-0,393$ & $-0,063$ & 1 & 0,052 & $-0,102$ & $-0,207$ & 0,097 & $\mathbf{- 0 , 3 5 8}$ \\
\hline MIRFX & 0,045 & 0,023 & 0,026 & 0,732 & & 0,779 & 0,58 & 0,255 & 0,598 & $\mathbf{0 , 0 4 4} * *$ \\
\hline & 0,145 & $-0,082$ & $-0,274$ & 0,786 & 0,052 & 1 & $-\mathbf{0 , 5 3 8}$ & $-0,298$ & $-0,269$ & $-0,147$ \\
\hline MIRTJ & 0,428 & 0,655 & 0,128 & 0 & 0,779 & & $\mathbf{0 , 0 0 2 *}$ & 0,098 & 0,137 & 0,421 \\
\hline & $-0,202$ & 0,339 & 0,418 & $-0,133$ & $-0,102$ & $-0,538$ & 1 & $\mathbf{0 , 5 1 2}$ & 0,096 & $-0,011$ \\
\hline MIRCRE & 0,268 & 0,058 & 0,017 & 0,467 & 0,58 & 0,002 & & $\mathbf{0 , 0 0 3} *$ & 0,602 & 0,95 \\
\hline & $-0,038$ & 0,152 & 0,823 & $-0,025$ & $-0,207$ & $-0,298$ & 0,512 & 1 & $\mathbf{0 , 3 9 3}$ & 0,075 \\
\hline MIRLIQ & 0,835 & 0,407 & 0 & 0,893 & 0,255 & 0,098 & 0,003 & & $\mathbf{0 , 0 2 6} * *$ & 0,682 \\
\hline & $-0,108$ & $-0,257$ & 0,245 & $-0,181$ & 0,097 & $-0,269$ & 0,096 & 0,393 & 1 & 0,02 \\
\hline MIRATPIB & 0,557 & 0,156 & 0,176 & 0,321 & 0,598 & 0,137 & 0,602 & 0,026 & & 0,913 \\
\hline & 0,129 & 0,472 & $-0,031$ & $-0,135$ & $-0,358$ & $-0,147$ & $-0,011$ & 0,075 & 0,02 & 1 \\
\hline
\end{tabular}

* Correlação significativa ao nível de significância de 1\% (2-tailed)

** Correlação significativa ao nível de significância de 5\% (2-tailed) 
Correlação de Pearson - desvios-padrão

\begin{tabular}{|l|r|r|r|r|r|r|r|r|r|r|}
\hline INDICADOR & DATPL & DALDT & DCAOC & DNOPPL & DROE & DIRFX & DIRTJ & DIRCRE & DIRLIQ & DIRATPIB \\
\hline DATPL & 1 & $-0,053$ & 0,154 & 0,215 & 0,194 & 0,082 & 0,114 & 0,067 & $-0,119$ & $-0,049$ \\
\hline & & 0,775 & 0,399 & 0,238 & 0,287 & 0,656 & 0,535 & 0,714 & 0,517 & 0,791 \\
\hline DALDT & $-0,053$ & 1 & 0,039 & 0,066 & $\mathbf{0 , 4 2 9}$ & $-0,132$ & 0,049 & 0,087 & $-0,114$ & $\mathbf{0 , 3 6 9}$ \\
\hline & 0,775 & & 0,832 & 0,718 & $\mathbf{0 , 0 1 4}$ & 0,471 & 0,79 & 0,637 & 0,536 & $\mathbf{0 , 0 3 8}$ \\
\hline DCAOC & 0,154 & 0,039 & 1 & $-0,194$ & 0,052 & $\mathbf{0 , 3 8 2}$ & $\mathbf{0 , 4 5 2}$ & $\mathbf{0 , 6 3 6}$ & $\mathbf{0 , 4 5 1}$ & $-0,178$ \\
\hline & 0,399 & 0,832 & & 0,287 & 0,779 & $\mathbf{0 , 0 3 1}$ & $\mathbf{0 , 0 0 9}$ & $\mathbf{0}$ & $\mathbf{0 , 0 0 9}$ & 0,33 \\
\hline DNOPPL & 0,215 & 0,066 & $-0,194$ & 1 & 0,082 & 0,286 & $-0,117$ & $-0,188$ & 0,14 & 0,239 \\
\hline & 0,238 & 0,718 & 0,287 & & 0,657 & 0,113 & 0,523 & 0,302 & 0,445 & 0,188 \\
\hline DROE & 0,194 & 0,429 & 0,052 & 0,082 & 1 & 0,2 & 0,034 & $-0,025$ & $-0,034$ & 0,091 \\
\hline & 0,287 & 0,014 & 0,779 & 0,657 & & 0,272 & 0,852 & 0,891 & 0,853 & 0,622 \\
\hline DIRFX & 0,082 & $-0,132$ & 0,382 & 0,286 & 0,2 & 1 & $\mathbf{0 , 7 4 5}$ & 0,341 & $\mathbf{0 , 6 2 8}$ & 0,134 \\
\hline & 0,656 & 0,471 & 0,031 & 0,113 & 0,272 & & $\mathbf{0}$ & 0,056 & $\mathbf{0}$ & 0,466 \\
\hline DIRTJ & 0,114 & 0,049 & 0,452 & $-0,117$ & 0,034 & 0,745 & 1 & $\mathbf{0 , 5 0 6}$ & $\mathbf{0 , 3 9 1}$ & 0,1 \\
\hline & 0,535 & 0,79 & 0,009 & 0,523 & 0,852 & 0 & & $\mathbf{0 , 0 0 3}$ & $\mathbf{0 , 0 2 7}$ & 0,587 \\
\hline DIRCRE & 0,067 & 0,087 & 0,636 & $-0,188$ & $-0,025$ & 0,341 & 0,506 & 1 & $\mathbf{0 , 4 6 9}$ & $-0,21$ \\
\hline & 0,714 & 0,637 & 0 & 0,302 & 0,891 & 0,056 & 0,003 & & $\mathbf{0 , 0 0 7}$ & 0,25 \\
\hline DIRLIQ & $-0,119$ & $-0,114$ & 0,451 & 0,14 & $-0,034$ & 0,628 & 0,391 & 0,469 & 1 & $-0,054$ \\
\hline & 0,517 & 0,536 & 0,009 & 0,445 & 0,853 & 0 & 0,027 & 0,007 & & 0,769 \\
\hline DIRATPIB & $-0,049$ & 0,369 & $-0,178$ & 0,239 & 0,091 & 0,134 & 0,1 & $-0,21$ & $-0,054$ & 1 \\
\hline & 0,791 & 0,038 & 0,33 & 0,188 & 0,622 & 0,466 & 0,587 & 0,25 & 0,769 & \\
\hline
\end{tabular}

* Correlação significativa ao nível de significância de 1\% (2-tailed)

** Correlação significativa ao nível de significância de 5\% (2-tailed) 


\section{ANEXO C: RESULTADOS DA ANÁLISE FATORIAL}

\section{Todos indicadores}

KMO and Bartlett's Test

\begin{tabular}{|c|c|c|}
\hline \multicolumn{2}{|c|}{$\begin{array}{l}\text { Kaiser-Meyer-Olkin Measure of Sampling } \\
\text { Adequacy. }\end{array}$} & 174, \\
\hline $\begin{array}{l}\text { Bartlett's Test of } \\
\text { Sphericity }\end{array}$ & $\begin{array}{l}\text { Approx. Chi-Square } \\
\text { df } \\
\text { Sig. }\end{array}$ & $\begin{array}{r}1145,741 \\
435 \\
, 000\end{array}$ \\
\hline
\end{tabular}

\section{Coeficientes de variação}

KMO and Bartlett's Test

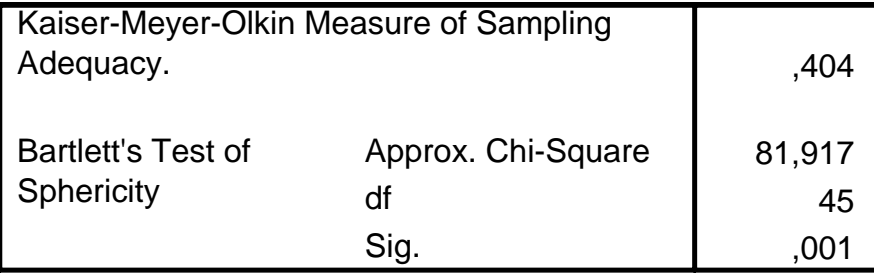

\section{Médias}

KMO and Bartlett's Test

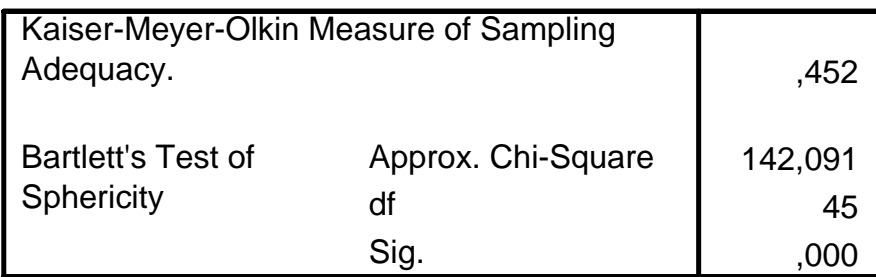

\section{Desvios-padrão}

KMO and Bartlett's Test

\begin{tabular}{|c|c|c|}
\hline \multicolumn{2}{|c|}{$\begin{array}{l}\text { Kaiser-Meyer-Olkin Measure of Sampling } \\
\text { Adequacy. }\end{array}$} & 386, \\
\hline \multirow{3}{*}{$\begin{array}{l}\text { Bartlett's Test of } \\
\text { Sphericity }\end{array}$} & Approx. Chi-Square & 119,994 \\
\hline & df & 45 \\
\hline & Sig. & 000, \\
\hline
\end{tabular}


ANEXO D: RESULTADO DA REGRESSÃO LOGÍSTICA - 10 COEFICIENTES

Block 0: Beginning Block

\section{Classification Table ${ }^{a, b}$}

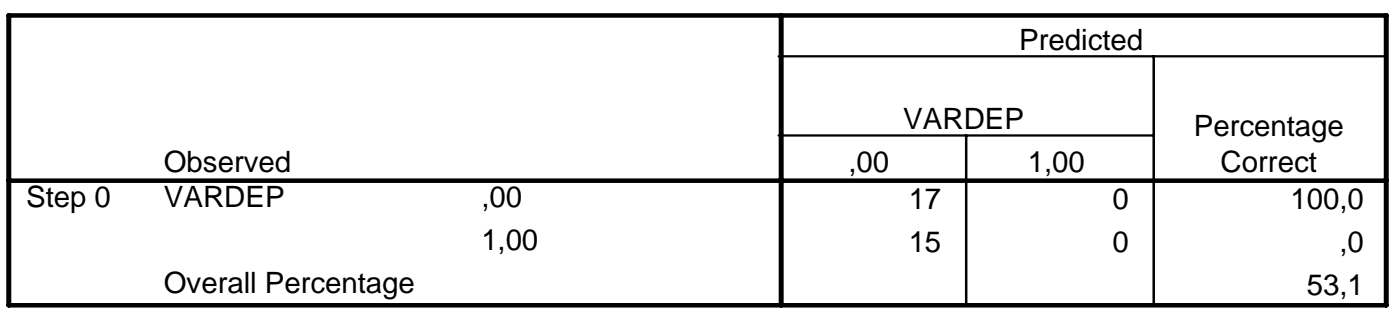

a. Constant is included in the model.

b. The cut value is, 500

Variables in the Equation

\begin{tabular}{|c|c|c|c|c|c|c|c|}
\hline & & $\mathrm{B}$ & S.E. & Wald & df & Sig. & $\operatorname{Exp}(B)$ \\
\hline Step 0 & Constant &,- 125 & ,354 & ,125 & 1 & ,724 & ,882 \\
\hline
\end{tabular}

Variables not in the Equation

\begin{tabular}{|c|c|c|c|c|c|}
\hline & & & Score & $d f$ & Sig. \\
\hline \multirow{11}{*}{$\begin{array}{l}\text { Step } \\
0\end{array}$} & \multirow[t]{10}{*}{ Variables } & CATPL & 2,510 & 1 & ,113 \\
\hline & & CALDT & ,748 & 1 & ,387 \\
\hline & & CCAOC & 1,761 & 1 & , 185 \\
\hline & & CNOPPL & ,706 & 1 & ,401 \\
\hline & & CROE & 5,676 & 1 & ,017 \\
\hline & & CIRFX & ,353 & 1 & , 552 \\
\hline & & CIRTJ & 2,193 & 1 & , 139 \\
\hline & & CIRCRE & , 182 & 1 & ,669 \\
\hline & & CIRLIQ & ,212 & 1 & ,645 \\
\hline & & CIRATPIB & ,667 & 1 & ,414 \\
\hline & \multicolumn{2}{|c|}{ Overall Statistics } & 17,314 & 10 & ,068 \\
\hline
\end{tabular}

Block 1: Method = Enter

Omnibus Tests of Model Coefficients

\begin{tabular}{|rl|r|r|r|}
\hline & & Chi-square & \multicolumn{1}{|c|}{ df } & \multicolumn{1}{c|}{ Sig. } \\
\hline Step 1 & Step & 44,236 & 10 &, 000 \\
& Block & 44,236 & 10 &, 000 \\
& Model & 44,236 & 10 &, 000 \\
\hline
\end{tabular}

Model Summary

\begin{tabular}{|l|r|r|r|}
\hline Step & $\begin{array}{c}-2 \text { Log } \\
\text { likelihood }\end{array}$ & $\begin{array}{c}\text { Cox \& Snell } \\
\text { R Square }\end{array}$ & $\begin{array}{c}\text { Nagelkerke } \\
\text { R Square }\end{array}$ \\
\hline 1 &, 000 &, 749 & 1,000 \\
\hline
\end{tabular}

Hosmer and Lemeshow Test

\begin{tabular}{|l|r|r|r|}
\hline Step & Chi-square & df & Sig. \\
\hline 1 &, 000 & & 6 \\
\hline
\end{tabular}


Contingency Table for Hosmer and Lemeshow Test

\begin{tabular}{|ll|r|r|r|r|r|}
\hline & & \multicolumn{2}{|c|}{ VARDEP $=, 00$} & \multicolumn{2}{c|}{ VARDEP $=1,00$} & \multicolumn{2}{|c|}{} \\
\cline { 2 - 6 } & & Observed & Expected & Observed & Expected & \multicolumn{2}{|c|}{ Total } \\
\hline Step & 1 & 3 & 3,000 & 0 &, 000 & 3 \\
1 & 2 & 3 & 3,000 & 0 &, 000 & 3 \\
& 3 & 3 & 3,000 & 0 &, 000 & 3 \\
& 4 & 3 & 3,000 & 0 &, 000 & 3 \\
& 5 & 2 & 3,000 & 0 &, 000 & 3 \\
& 6 & 0 & 2,000 & 1 & 1,000 & 3 \\
& 7 & 0 &, 000 & 2 & 2,000 & 2 \\
& 8 & & & 12 & 12,000 & 12 \\
\hline
\end{tabular}

Classification Table ${ }^{a}$

\begin{tabular}{|c|c|c|c|c|c|}
\hline & & & & Predicte & \\
\hline & & & & & Percentage \\
\hline & Observec & &, 00 & 1,00 & Correct \\
\hline Step 1 & VARDEP & ,00 & 17 & 0 & 100,0 \\
\hline & & 1,00 & 0 & 15 & 100,0 \\
\hline & Overall P & & & & 100,0 \\
\hline
\end{tabular}

a. The cut value is, 500

Variables in the Equation

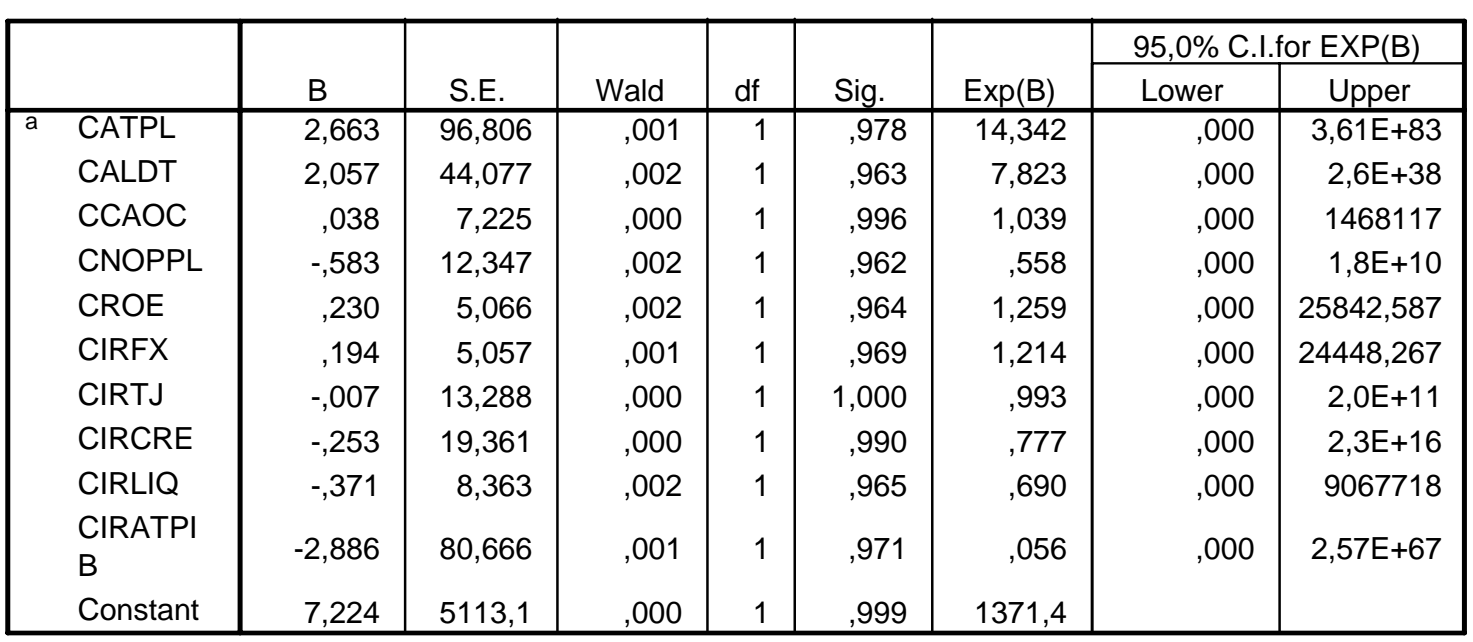

a. Variable(s) entered on step 1: CATPL, CALDT, CCAOC, CNOPPL, CROE, CIRFX, CIRTJ, CIRCRE, CIRLIQ, CIRATPIB. 
ANEXO E: RESULTADO DA REGRESSÃO LOGÍSTICA - 10 MÉDIAS

Block 0: Beginning Block

\section{Classification Table ${ }^{a, b}$}

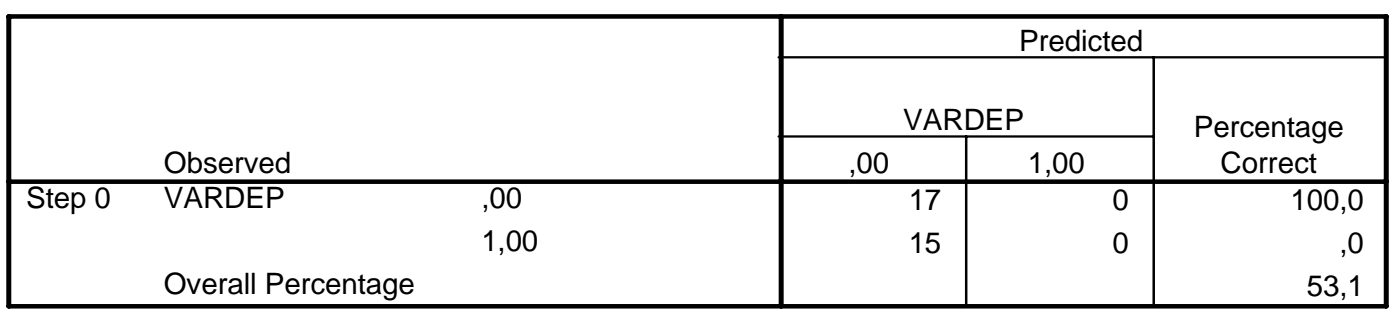

a. Constant is included in the model.

b. The cut value is ,500

Variables in the Equation

\begin{tabular}{|c|c|c|c|c|c|c|c|}
\hline & & B & S.E. & Wald & $\mathrm{df}$ & Sig. & $\operatorname{Exp}(B)$ \\
\hline$\overline{\text { Step } 0}$ & Constant &,- 125 & ,354 & ,125 & 1 & ,724 & ,882 \\
\hline
\end{tabular}

\begin{tabular}{|c|c|c|c|c|c|}
\hline & & & Score & $\mathrm{df}$ & Sig. \\
\hline \multirow{11}{*}{$\begin{array}{l}\text { Step } \\
0\end{array}$} & \multirow[t]{10}{*}{ Variables } & MATPL & 5,945 & 1 & ,015 \\
\hline & & MALDT & ,743 & 1 & ,389 \\
\hline & & MCAOC & 12,457 & 1 & ,000 \\
\hline & & MNOPPL & ,033 & 1 & ,857 \\
\hline & & MROE & 7,551 & 1 & ,006 \\
\hline & & MIRFX & 3,295 & 1 & ,069 \\
\hline & & MIRTJ & 11,863 & 1 & ,001 \\
\hline & & MIRCRE & 8,614 & 1 & ,003 \\
\hline & & MIRLIQ & ,865 & 1 & ,352 \\
\hline & & MIRATPIB & ,860 & 1 & ,354 \\
\hline & \multicolumn{2}{|c|}{ Overall Statistics } & 23,224 & 10 & ,010 \\
\hline
\end{tabular}

Block 1: Method = Enter

Omnibus Tests of Model Coefficients

\begin{tabular}{|ll|r|r|r|}
\hline & & Chi-square & df & \multicolumn{1}{c|}{ Sig. } \\
\hline Step 1 & Step & 44,236 & 10 &, 000 \\
& Block & 44,236 & 10 &, 000 \\
& Model & 44,236 & 10 &, 000 \\
\hline
\end{tabular}

Model Summary

\begin{tabular}{|l|r|r|r|}
\hline Step & $\begin{array}{c}-2 \text { Log } \\
\text { likelihood }\end{array}$ & $\begin{array}{c}\text { Cox \& Snell } \\
\text { R Square }\end{array}$ & $\begin{array}{c}\text { Nagelkerke } \\
\text { R Square }\end{array}$ \\
\hline 1 &, 000 &, 749 & 1,000 \\
\hline
\end{tabular}

Hosmer and Lemeshow Test

\begin{tabular}{|l|r|r|r|}
\hline Step & Chi-square & df & Sig. \\
\hline 1 &, 000 & 7 & 1,000 \\
\hline
\end{tabular}


Contingency Table for Hosmer and Lemeshow Test

\begin{tabular}{|c|c|c|c|c|c|c|}
\hline & \multicolumn{2}{|c|}{ VARDEP $=, 00$} & \multicolumn{2}{|c|}{ VARDEP $=1,00$} & \multirow[b]{2}{*}{ Total } \\
\hline & & Observed & Expected & Observed & Expected & \\
\hline \multirow{9}{*}{$\begin{array}{l}\text { Step } \\
1\end{array}$} & 1 & 3 & 3,000 & $\overline{0}$ & ,000 & $\overline{3}$ \\
\hline & 2 & 3 & 3,000 & 0 & ,000 & 3 \\
\hline & 3 & 3 & 3,000 & 0 & 000 & 3 \\
\hline & 4 & 3 & 3,000 & 0 & 000 & 3 \\
\hline & 5 & 3 & 3,000 & 0 & ,000 & 3 \\
\hline & 6 & 2 & 2,000 & 1 & 1,000 & 3 \\
\hline & 7 & 0 & ,000 & 3 & 3,000 & 3 \\
\hline & 8 & 0 & ,000 & 3 & 3,000 & 3 \\
\hline & 9 & 0 & ,000 & 8 & 8,000 & 8 \\
\hline
\end{tabular}

\section{Classification Table ${ }^{\mathrm{a}}$}

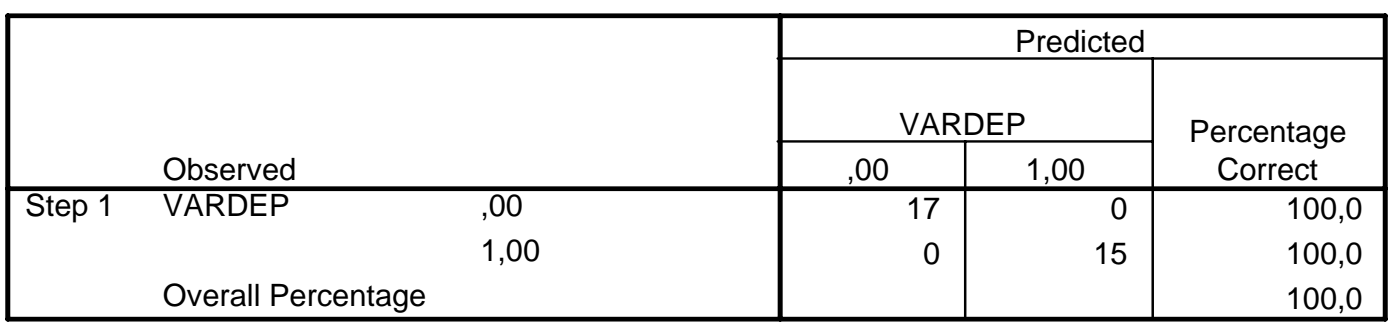

a. The cut value is, 500

\begin{tabular}{|c|c|c|c|c|c|c|c|c|c|}
\hline & \multirow[b]{2}{*}{ B } & \multirow[b]{2}{*}{ S.E. } & \multirow[b]{2}{*}{ Wald } & \multirow[b]{2}{*}{ df } & \multirow[b]{2}{*}{ Sig. } & \multirow[b]{2}{*}{$\operatorname{Exp}(B)$} & \multicolumn{2}{|c|}{ 95,0\% C.I.for EXP(B) } \\
\hline & & & & & & & & Lower & Upper \\
\hline \multirow[t]{11}{*}{$\mathrm{a}$} & MATPL &, 000 & 800 & ,000 & 1 & 1,000 & 1,000 & ,208 & 4,798 \\
\hline & MALDT &,- 057 & 23,57 & ,000 & 1 & ,998 & ,945 & ,000 & $1,1 \mathrm{E}+20$ \\
\hline & MCAOC & ,433 & 235,1 & ,000 & 1 & ,999 & 1,541 & ,000 & $2,16+200$ \\
\hline & MNOPPL &,- 007 & 34,42 & ,000 & 1 & 1,000 & ,993 & ,000 & $2,0 E+29$ \\
\hline & MROE &,- 056 & 168,1 & ,000 & 1 & 1,000 & ,945 & ,000 & $1,18+143$ \\
\hline & MIRFX & ,005 & 13,19 & ,000 & 1 & 1,000 & 1,005 & ,000 & $1,7 \mathrm{E}+11$ \\
\hline & MIRTJ & ,004 & 3,861 & ,000 & 1 & 1,000 & 1,004 & ,001 & 1940,202 \\
\hline & MIRCRE & ,053 & 84,00 & ,000 & 1 & 1,000 & 1,054 & ,000 & $3,35 E+71$ \\
\hline & MIRLIQ &,- 004 & 2,521 & ,000 & 1 & ,999 & ,996 & ,007 & 139,405 \\
\hline & MIRATPIB & ,006 & 2,583 & ,000 & 1 & ,998 & 1,006 & ,006 & 159,121 \\
\hline & Constant & $-34,04$ & 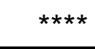 & ,000 & 1 & 1,000 & ,000 & & \\
\hline
\end{tabular}

a. Variable(s) entered on step 1: MATPL, MALDT, MCAOC, MNOPPL, MROE, MIRFX, MIRTJ, MIRCRE, MIRLIQ, MIRATPIB. 
ANEXO F: RESULTADO DA REGRESSÃO LOGÍSTICA - 10 DESVIOS-PADRÃO

Block 0: Beginning Block

\section{Classification Table ${ }^{a, b}$}

\begin{tabular}{|c|c|c|c|c|c|}
\hline & & & & Predicte & \\
\hline & & & & & Percentage \\
\hline & Observed & & ,00 & 1,00 & Correct \\
\hline Step 0 & VARDEP & ,00 & 17 & $c$ & 100,0 \\
\hline & & 1,00 & 15 & c & , 0 \\
\hline & Overall $\mathrm{P}$ & & & & 53,1 \\
\hline
\end{tabular}

a. Constant is included in the model.

b. The cut value is ,500

Variables in the Equation

\begin{tabular}{|c|c|c|c|c|c|c|c|}
\hline & & B & S.E. & Wald & $\mathrm{df}$ & Sig. & $\operatorname{Exp}(B)$ \\
\hline$\overline{\text { Step } 0}$ & Constant &,- 125 & ,354 & ,125 & 1 & ,724 & ,882 \\
\hline
\end{tabular}

Variables not in the Equation

\begin{tabular}{|c|c|c|c|c|c|}
\hline & & & Score & df & Sig. \\
\hline \multirow{11}{*}{$\begin{array}{l}\text { Step } \\
0\end{array}$} & \multirow[t]{10}{*}{ Variables } & DATPL & ,189 & 1 &, 664 \\
\hline & & DALDT & 1,374 & 1 & ,241 \\
\hline & & DCAOC & 9,693 & 1 & ,002 \\
\hline & & DNOPPL & 5,211 & 1 & ,022 \\
\hline & & DROE & 7,453 & 1 & ,006 \\
\hline & & DIRFX & 7,225 & 1 & ,007 \\
\hline & & DIRTJ & 12,447 & 1 & ,000 \\
\hline & & DIRCRE & 6,360 & 1 & ,012 \\
\hline & & DIRLIQ & ,963 & 1 & ,326 \\
\hline & & DIRATPIB & ,010 & 1 & ,922 \\
\hline & \multicolumn{2}{|c|}{ Overall Statistics } & 26,370 & 10 & ,003 \\
\hline
\end{tabular}

Block 1: Method = Enter

Omnibus Tests of Model Coefficients

\begin{tabular}{|ll|r|r|r|}
\hline & & Chi-square & df & \multicolumn{1}{c|}{ Sig. } \\
\hline Step 1 & Step & 44,236 & 10 &, 000 \\
& Block & 44,236 & 10 &, 000 \\
& Model & 44,236 & 10 &, 000 \\
\hline
\end{tabular}

Model Summary

\begin{tabular}{|l|r|r|r|}
\hline Step & $\begin{array}{c}-2 \text { Log } \\
\text { likelihood }\end{array}$ & $\begin{array}{c}\text { Cox \& Snell } \\
\text { R Square }\end{array}$ & $\begin{array}{c}\text { Nagelkerke } \\
\text { R Square }\end{array}$ \\
\hline 1 &, 000 &, 749 & 1,000 \\
\hline
\end{tabular}

Hosmer and Lemeshow Test

\begin{tabular}{|l|r|r|r|}
\hline Step & Chi-square & df & Sig. \\
\hline 1 &, 000 & 7 & 1,000 \\
\hline
\end{tabular}


Contingency Table for Hosmer and Lemeshow Test

\begin{tabular}{|ll|r|r|r|r|r|}
\hline & & \multicolumn{2}{|c|}{ VARDEP $=, 00$} & \multicolumn{2}{c|}{ VARDEP $=1,00$} & \multirow{2}{*}{ Total } \\
\cline { 2 - 6 } & & Observed & Expected & Observed & Expected & \multicolumn{2}{c|}{} \\
\hline Step & 1 & 3 & 3,000 & 0 &, 000 & 3 \\
& 2 & 3 & 3,000 & 0 &, 000 & 3 \\
& 3 & 3 & 3,000 & 0 &, 000 & 3 \\
& 4 & 3 & 3,000 & 0 &, 000 & 3 \\
& 5 & 3 & 3,000 & 0 &, 000 & 3 \\
6 & 2 & 2,000 & 1 & 1,000 & 3 \\
& 7 & 0 &, 000 & 3 & 3,000 & 2 \\
& 8 & 0 &, 000 & 2 & 2,000 & 9 \\
\hline
\end{tabular}

Classification Table $^{\mathrm{a}}$

\begin{tabular}{|c|c|c|c|c|c|}
\hline & & & & Predicted & \\
\hline & & & & & Percentage \\
\hline & Observed & &, 00 & 1,00 & Correct \\
\hline Step 1 & VARDEP & ,00 & $\overline{17}$ & 0 & 100,0 \\
\hline & & 1,00 & 0 & 15 & 100,0 \\
\hline & Overall $\mathrm{P}$ & & & & 100,0 \\
\hline
\end{tabular}

a. The cut value is, 500

Variables in the Equation

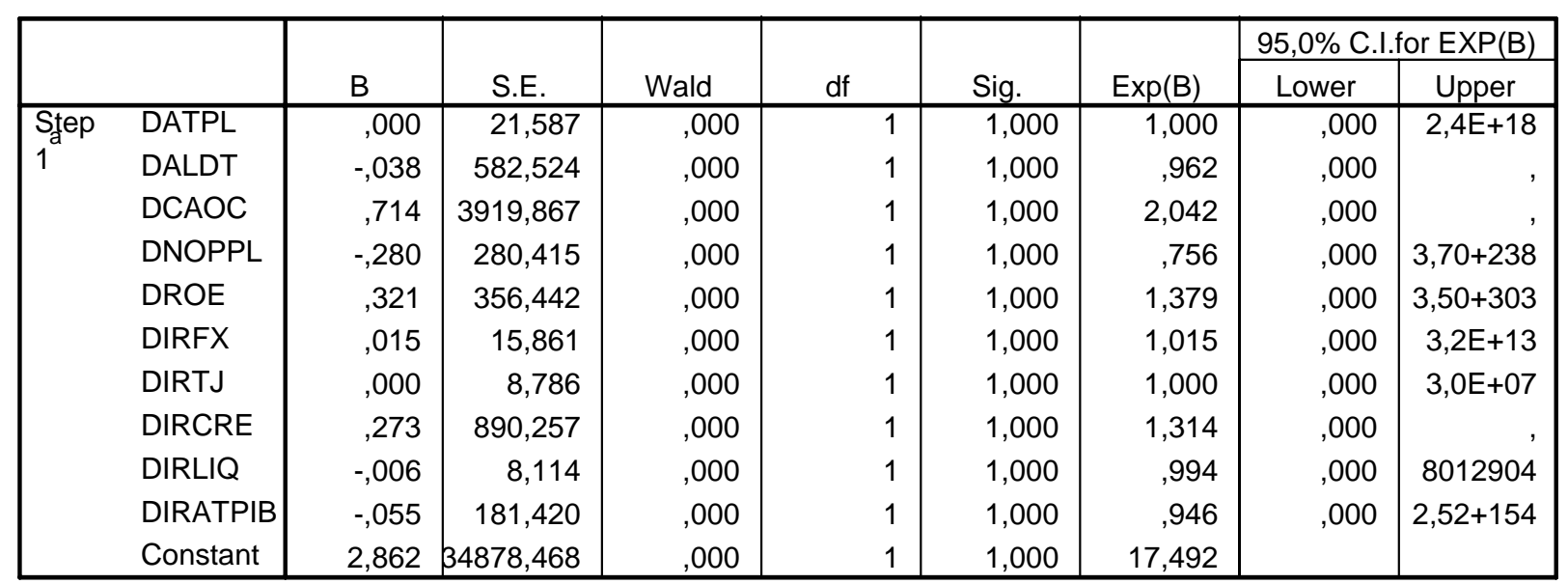

a. Variable(s) entered on step 1: DATPL, DALDT, DCAOC, DNOPPL, DROE, DIRFX, DIRTJ, DIRCRE, DIRLIQ, DIRATPIB. 
ANEXO G: RESULTADO DA REGRESSÃO LOGÍSTICA - CROE E CIRTJ

Block 0: Beginning Block

\begin{tabular}{|lll|r|r|r|}
\hline & & Score & df & \multicolumn{1}{c|}{ Sig. } \\
\hline Step & Variables & CROE & 5,676 & 1 &, 017 \\
0 & & CIRTJ & 2,193 & 1 &, 139 \\
& Overall Statistics & & 7,697 & 2 &, 021 \\
\hline
\end{tabular}

Block 1: Method = Enter

\begin{tabular}{|ll|r|r|r|}
\hline & & Chi-square & df & \multicolumn{1}{c|}{ Sig. } \\
\hline Step 1 & Step & 23,610 & &, 000 \\
& Block & 23,610 & 2 &, 000 \\
& Model & 23,610 & 2 &, 000 \\
\hline
\end{tabular}

\begin{tabular}{|l|c|c|c|}
\hline Step & $\begin{array}{c}-2 \text { Log } \\
\text { likelihood }\end{array}$ & $\begin{array}{c}\text { Cox \& Snell } \\
\text { R Square }\end{array}$ & $\begin{array}{c}\text { Nagelkerke } \\
\text { R Square }\end{array}$ \\
\hline 1 & 20,626 &, 522 &, 697 \\
\hline
\end{tabular}

\begin{tabular}{|l|r|r|r|}
\hline Step & Chi-square & df & Sig. \\
\hline 1 & 8,214 & & 8 \\
\hline
\end{tabular}

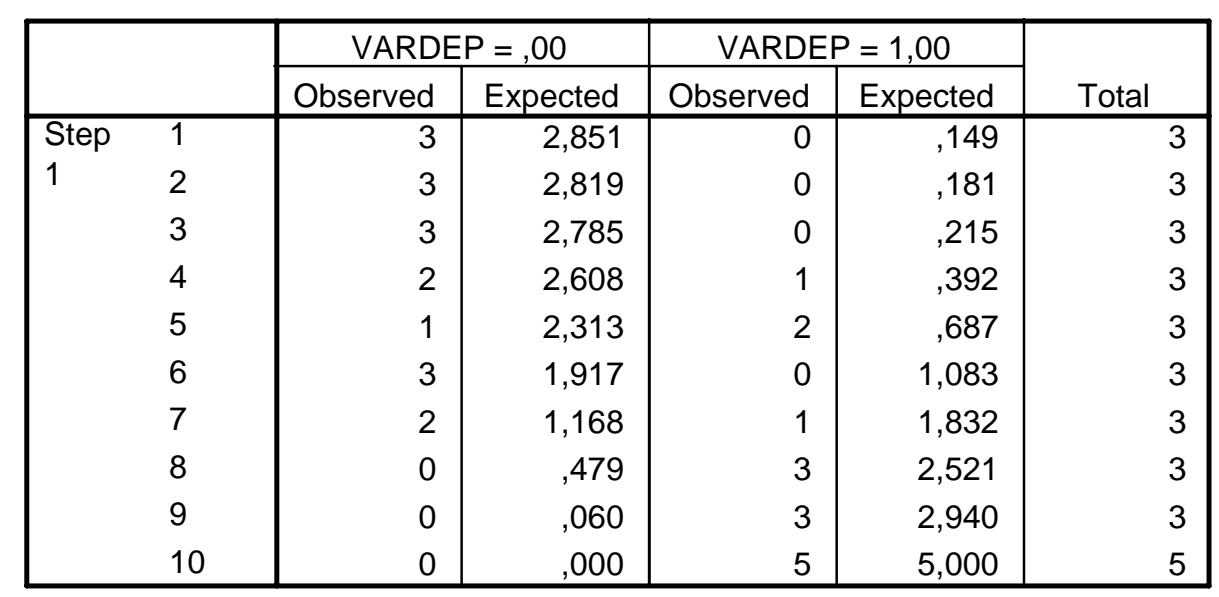

\begin{tabular}{|c|c|c|c|c|c|}
\hline & & & \multicolumn{3}{|c|}{ Predicted } \\
\hline & \multirow{2}{*}{\multicolumn{2}{|c|}{ Observed }} & \multicolumn{2}{|c|}{ VARDEP } & \multirow{2}{*}{$\begin{array}{c}\text { Percentage } \\
\text { Correct }\end{array}$} \\
\hline & & & ,00 & 1,00 & \\
\hline \multirow[t]{3}{*}{ Step 1} & VARDEP &, 00 & 15 & 2 & 88,2 \\
\hline & & 1,00 & 3 & 12 & 80,0 \\
\hline & Overall $\mathrm{P}$ & & & & 84,4 \\
\hline
\end{tabular}

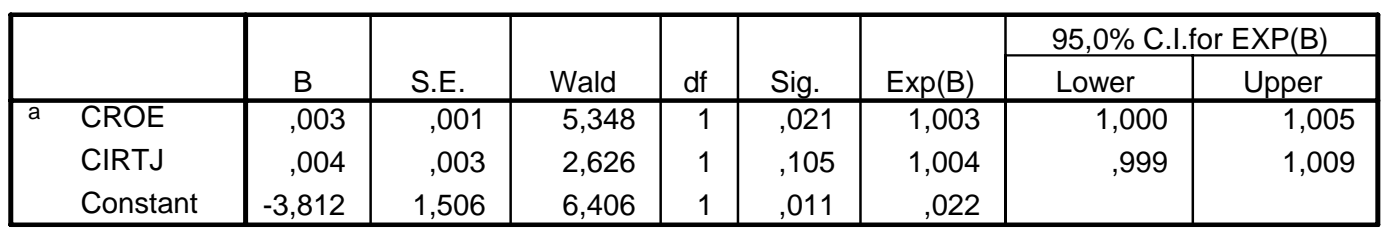

a. Variable(s) entered on step 1: CROE, CIRTJ. 


\section{ANEXO H: RESULTADO DA REGRESSÃO LOGÍSTICA - MROE E MIRCRE}

Block 0: Beginning Block

\begin{tabular}{|lll|r|r|r|}
\hline & & \multicolumn{1}{|c|}{ Score } & df & \multicolumn{1}{c|}{ Sig. } \\
\hline Step & Variables & MROE & 7,551 & 1 &, 006 \\
0 & & MIRCRE & 8,614 & 1 &, 003 \\
& Overall Statistics & & 13,399 & 2 &, 001 \\
\hline
\end{tabular}

Block 1: Method = Enter

\begin{tabular}{|rl|r|r|r|}
\hline & & Chi-square & \multicolumn{1}{c|}{ df } & \multicolumn{1}{c|}{ Sig. } \\
\hline Step 1 & Step & 29,771 & 2 &, 000 \\
& Block & 29,771 & 2 &, 000 \\
& Model & 29,771 & 2 &, 000 \\
\hline
\end{tabular}

\begin{tabular}{|l|c|c|c|}
\hline Step & $\begin{array}{c}-2 \text { Log } \\
\text { likelihood }\end{array}$ & $\begin{array}{c}\text { Cox \& Snell } \\
\text { R Square }\end{array}$ & $\begin{array}{c}\text { Nagelkerke } \\
\text { R Square }\end{array}$ \\
\hline 1 & 14,465 &, 606 &, 809 \\
\hline
\end{tabular}

\begin{tabular}{|l|r|r|r|}
\hline Step & Chi-square & df & Sig. \\
\hline 1 & 5,113 & & 8 \\
\hline
\end{tabular}

\begin{tabular}{|c|c|c|c|c|c|c|}
\hline & \multicolumn{2}{|c|}{ VARDEP $=, 00$} & \multicolumn{2}{|c|}{ VARDEP $=1,00$} & \multirow[b]{2}{*}{ Total } \\
\hline & & Observed & Expected & Observed & Expected & \\
\hline \multirow{10}{*}{$\begin{array}{l}\text { Step } \\
1\end{array}$} & 1 & 3 & 2,985 & 0 & ,015 & 3 \\
\hline & 2 & 3 & 2,970 & 0 & ,030 & 3 \\
\hline & 3 & 3 & 2,884 & 0 & 116 & 3 \\
\hline & 4 & 3 & 2,758 & 0 & ,242 & 3 \\
\hline & 5 & 2 & 2,488 & 1 & ,512 & 3 \\
\hline & 6 & 2 & 1,978 & 1 & 1,022 & 3 \\
\hline & 7 & 0 & ,712 & 3 & 2,288 & 3 \\
\hline & 8 & 1 & ,211 & 2 & 2,789 & 3 \\
\hline & 9 & 0 & ,013 & 3 & 2,987 & 3 \\
\hline & 10 & 0 & , 000 & 5 & 5,000 & 5 \\
\hline
\end{tabular}

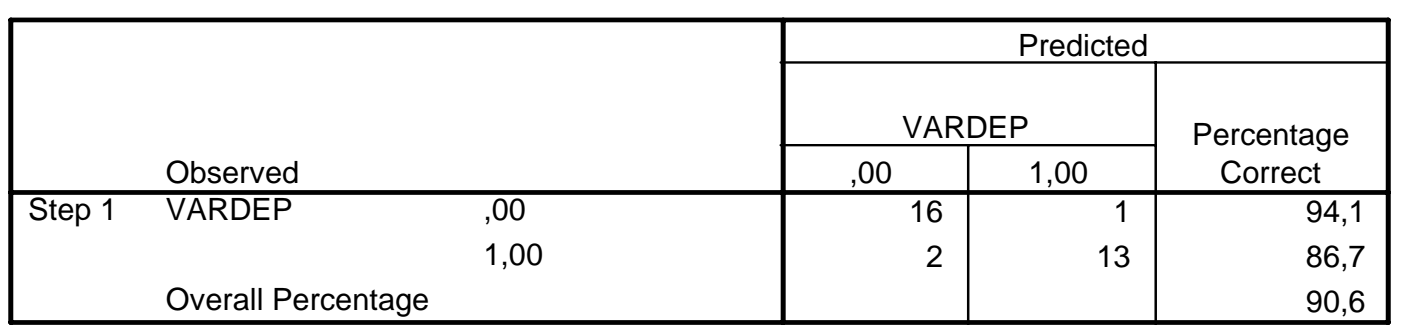

\begin{tabular}{|c|c|c|c|c|c|c|c|c|c|}
\hline & \multirow[b]{2}{*}{ B } & \multirow[b]{2}{*}{ S.E. } & \multirow[b]{2}{*}{ Wald } & \multirow[b]{2}{*}{ df } & \multirow[b]{2}{*}{ Sig. } & \multirow[b]{2}{*}{$\operatorname{Exp}(B)$} & \multicolumn{2}{|c|}{ 95,0\% C.I.for EXP(B) } \\
\hline & & & & & & & & Lower & Upper \\
\hline \multirow{3}{*}{$\begin{array}{l}\text { Step } \\
1\end{array}$} & MROE &,- 032 & ,014 & 5,257 & 1 & ,022 & 968 & ,942 & ,995 \\
\hline & MIRCRE & ,042 & ,018 & 5,318 & 1 & ,021 & 1,042 & 1,006 & 1,080 \\
\hline & Constant & $-2,147$ & 1,455 & 2,179 & 1 & , 140 & ,117 & & \\
\hline
\end{tabular}

a. Variable(s) entered on step 1: MROE, MIRCRE. 
ANEXO I: RESULTADO DA REGRESSÃO LOGÍSTICA - MROE E MIRTJ

Block 0: Beginning Block

\begin{tabular}{|lll|r|r|r|}
\hline & & \multicolumn{1}{|c|}{ Score } & df & \multicolumn{1}{c|}{ Sig. } \\
\hline Step & Variables & MIRTJ & 11,863 & 1 &, 001 \\
0 & & MROE & 7,551 & 1 &, 006 \\
& & & 17,674 & & 2 \\
\hline
\end{tabular}

Block 1: Method = Enter

\begin{tabular}{|rl|r|r|r|}
\hline & & Chi-square & \multicolumn{1}{c|}{ df } & \multicolumn{1}{c|}{ Sig. } \\
\hline Step 1 & Step & 29,138 & 2 &, 000 \\
& Block & 29,138 & 2 &, 000 \\
& Model & 29,138 & 2 &, 000 \\
\hline
\end{tabular}

\begin{tabular}{|l|r|r|r|}
\hline Step & $\begin{array}{c}-2 \text { Log } \\
\text { likelihood }\end{array}$ & $\begin{array}{c}\text { Cox \& Snell } \\
\text { R Square }\end{array}$ & $\begin{array}{c}\text { Nagelkerke } \\
\text { R Square }\end{array}$ \\
\hline 1 & 15,098 &, 598 &, 798 \\
\hline
\end{tabular}

\begin{tabular}{|l|r|r|r|}
\hline Step & Chi-square & df & \multicolumn{1}{c|}{ Sig. } \\
\hline 1 & 4,295 & & 8 \\
\hline
\end{tabular}

\begin{tabular}{|c|c|c|c|c|c|c|}
\hline & & \multicolumn{2}{|c|}{ VARDEP $=, 00$} & \multicolumn{2}{|c|}{ VARDEP $=1,00$} & \multirow[b]{2}{*}{ Total } \\
\hline & & Observed & Expected & Observed & Expected & \\
\hline \multirow{10}{*}{$\begin{array}{l}\text { Step } \\
1\end{array}$} & 1 & 3 & 2,995 & 0 & ,005 & 3 \\
\hline & 2 & 3 & 2,979 & 0 & ,021 & 3 \\
\hline & 3 & 3 & 2,887 & 0 & 113 & 3 \\
\hline & 4 & 3 & 2,747 & 0 & ,253 & 3 \\
\hline & 5 & 2 & 2,316 & 1 & ,684 & 3 \\
\hline & 6 & 1 & 1,994 & 2 & 1,006 & 3 \\
\hline & 7 & 2 & ,884 & 1 & 2,116 & 3 \\
\hline & 8 & 0 & , 163 & 3 & 2,837 & 3 \\
\hline & 9 & 0 & ,032 & 3 & 2,968 & 3 \\
\hline & 10 & 0 & ,002 & 5 & 4,998 & 5 \\
\hline
\end{tabular}

\begin{tabular}{|c|c|c|c|c|c|}
\hline & \multirow[b]{3}{*}{ Observed } & & \multicolumn{3}{|c|}{ Predicted } \\
\hline & & & \multicolumn{2}{|c|}{ VARDEP } & \multirow{2}{*}{$\begin{array}{c}\text { Percentage } \\
\text { Correct }\end{array}$} \\
\hline & & & ,00 & 1,00 & \\
\hline \multirow[t]{3}{*}{ Step 1} & VARDEP &, 00 & 15 & 2 & 88,2 \\
\hline & & 1,00 & 3 & 12 & 80,0 \\
\hline & Overall $\mathrm{P}$ & & & & 84,4 \\
\hline
\end{tabular}

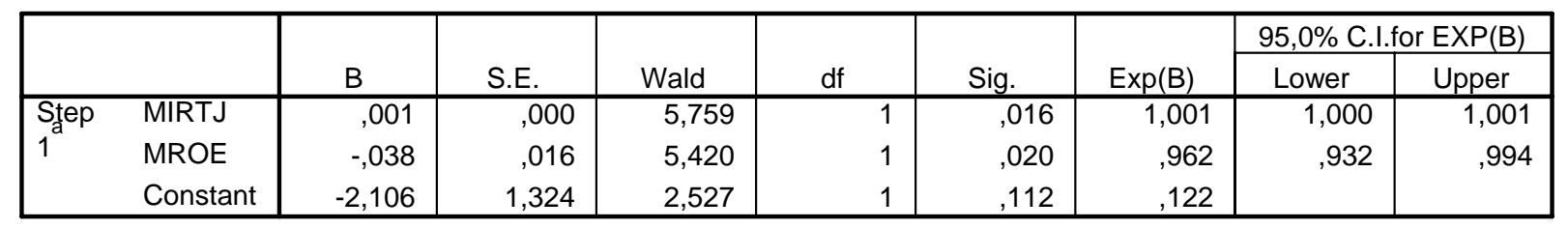

a. Variable(s) entered on step 1: MIRTJ, MROE. 


\section{ANEXO J: RESULTADO DA REGRESSÃO LOGÍSTICA - DROE E DIRTJ}

Block 0: Beginning Block

\begin{tabular}{|lll|r|r|r|}
\hline & & \multicolumn{1}{|c|}{ Score } & df & \multicolumn{1}{c|}{ Sig. } \\
\hline Step & Variables & DROE & 7,453 & 1 &, 006 \\
0 & & DIRTJ & 12,447 & 1 &, 000 \\
& Overall Statistics & & 19,261 & 2 &, 000 \\
\hline
\end{tabular}

Block 1: Method = Enter

\begin{tabular}{|rl|r|r|r|}
\hline & & Chi-square & \multicolumn{1}{c|}{ df } & \multicolumn{1}{c|}{ Sig. } \\
\hline Step 1 & Step & 26,863 & 2 &, 000 \\
& Block & 26,863 & 2 &, 000 \\
& Model & 26,863 & 2 &, 000 \\
\hline
\end{tabular}

\begin{tabular}{|l|r|r|r|}
\hline Step & $\begin{array}{c}-2 \text { Log } \\
\text { likelihood }\end{array}$ & $\begin{array}{c}\text { Cox \& Snell } \\
\text { R Square }\end{array}$ & $\begin{array}{c}\text { Nagelkerke } \\
\text { R Square }\end{array}$ \\
\hline 1 & 17,374 &, 568 &, 758 \\
\hline
\end{tabular}

\begin{tabular}{|l|r|r|r|}
\hline Step & Chi-square & df & \multicolumn{1}{c|}{ Sig. } \\
\hline 1 & 4,345 & 8 &, 825 \\
\hline
\end{tabular}

\begin{tabular}{|ll|r|r|r|r|r|}
\hline & & \multicolumn{2}{|c|}{ VARDEP $=, 00$} & \multicolumn{2}{c|}{ VARDEP $=1,00$} & \multirow{2}{*}{ Total } \\
\cline { 2 - 6 } & & Observed & Expected & Observed & Expected & 3 \\
\hline Step & 1 & 3 & 2,889 & 0 &, 111 & 3 \\
& 2 & 3 & 2,874 & 0 &, 126 & 3 \\
& 3 & 3 & 2,821 & 0 &, 179 & 3 \\
& 4 & 2 & 2,703 & 1 &, 297 & 3 \\
& 5 & 2 & 2,460 & 1 &, 540 & 3 \\
6 & 3 & 2,118 & 0 &, 882 & 3 \\
& 1 &, 854 & 2 & 2,146 & 3 \\
& 0 & 0 &, 218 & 3 & 2,782 & 3 \\
9 & 0 &, 058 & 3 & 2,942 & 5 \\
\hline
\end{tabular}

\begin{tabular}{|c|c|c|c|c|c|}
\hline & & & & Predicte & \\
\hline & & & VAF & & Percentage \\
\hline & Observed & &, 00 & 1,00 & Correct \\
\hline$\overline{\text { Step } 1}$ & VARDEP & 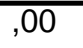 & 16 & 1 & 94,1 \\
\hline & & 1,00 & 2 & 13 & 86,7 \\
\hline & Overall $\mathrm{P}$ & & & & 90,6 \\
\hline
\end{tabular}

\begin{tabular}{|c|c|c|c|c|c|c|c|c|c|}
\hline & & \multirow[b]{2}{*}{ B } & \multirow[b]{2}{*}{ S.E. } & \multirow[b]{2}{*}{ Wald } & \multirow[b]{2}{*}{ df } & \multirow[b]{2}{*}{ Sig. } & \multirow[b]{2}{*}{$\operatorname{Exp}(B)$} & \multicolumn{2}{|c|}{ 95,0\% C.I.for EXP(B) } \\
\hline & & & & & & & & Lower & Upper \\
\hline \multirow{3}{*}{$\begin{array}{l}\text { Step } \\
1\end{array}$} & DROE & ,046 & ,024 & 3,617 & 1 & ,057 & 1,047 & 999 & 1,098 \\
\hline & DIRTJ & ,001 & ,000 & 6,217 & 1 & ,013 & 1,001 & 1,000 & 1,001 \\
\hline & Constant & $-3,871$ & 1,287 & 9,043 & 1 & ,003 & ,021 & & \\
\hline
\end{tabular}

a. Variable(s) entered on step 1: DROE, DIRTJ. 
ANEXO K: RESULTADO DA REGRESSÃO LOGÍSTICA - DCAOC

Block 0: Beginning Block

\begin{tabular}{|c|c|c|c|c|}
\hline & & Score & df & Sig. \\
\hline \multirow[t]{2}{*}{ Step 0} & Variables & 9,693 & 1 &, 002 \\
\hline & Overall Statistics & 9,693 & 1 & ,002 \\
\hline
\end{tabular}

Block 1: Method = Enter

\begin{tabular}{|rl|r|r|r|}
\hline & & Chi-square & \multicolumn{1}{c|}{ df } & \multicolumn{1}{c|}{ Sig. } \\
\hline Step 1 & Step & 37,862 & 1 &, 000 \\
& Block & 37,862 & 1 &, 000 \\
& Model & 37,862 & 1 &, 000 \\
\hline
\end{tabular}

\begin{tabular}{|l|r|r|r|}
\hline Step & $\begin{array}{c}-2 \text { Log } \\
\text { likelihood }\end{array}$ & $\begin{array}{c}\text { Cox \& Snell } \\
\text { R Square }\end{array}$ & $\begin{array}{c}\text { Nagelkerke } \\
\text { R Square }\end{array}$ \\
\hline 1 & 6,374 &, 694 &, 926 \\
\hline
\end{tabular}

\begin{tabular}{|l|r|r|r|}
\hline Step & Chi-square & df & Sig. \\
\hline 1 &, 397 & 7 & 1,000 \\
\hline
\end{tabular}

\begin{tabular}{|ll|r|r|r|r|r|}
\hline & & \multicolumn{2}{|c|}{ VARDEP $=, 00$} & \multicolumn{2}{c|}{ VARDEP $=1,00$} & \multicolumn{2}{c|}{} \\
\cline { 2 - 6 } & & Observed & Expected & Observed & Expected & \multicolumn{2}{|c}{ Total } \\
\hline Step & 1 & 1 & 1,000 & 0 &, 000 & 1 \\
1 & 2 & 10 & 9,983 & 0 &, 017 & 10 \\
& 3 & 2 & 1,978 & 0 &, 022 & 2 \\
& 4 & 3 & 2,793 & 0 &, 207 & 3 \\
& 5 & 1 & 1,141 & 2 & 1,859 & 3 \\
& 6 & 0 &, 103 & 4 & 3,897 & 4 \\
& 7 & 0 &, 002 & 3 & 2,998 & 3 \\
& 0 & 0 &, 000 & 1 & 1,000 & 1 \\
9 & & & 5 & 5,000 & 5 \\
\hline
\end{tabular}

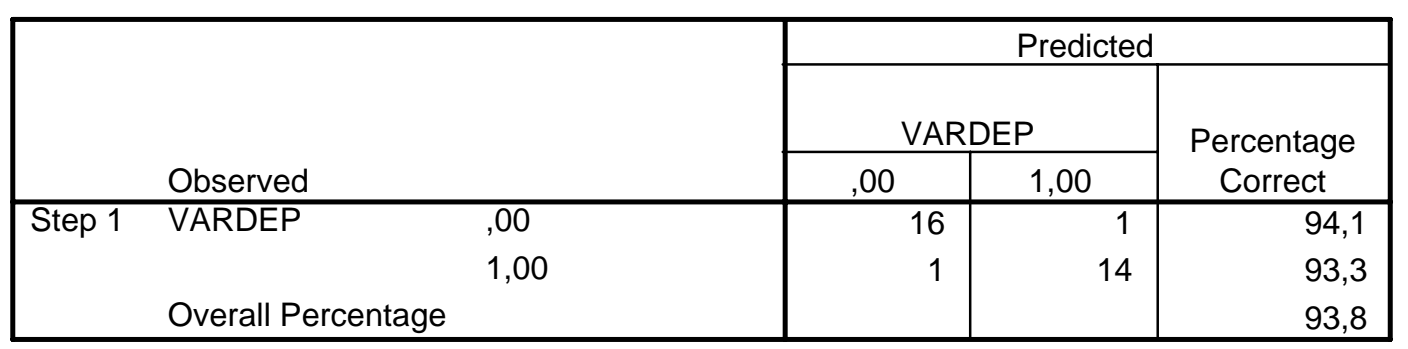

\begin{tabular}{|c|c|c|c|c|c|c|c|c|c|}
\hline & \multirow[b]{2}{*}{ B } & \multirow[b]{2}{*}{ S.E. } & \multirow[b]{2}{*}{ Wald } & \multirow[b]{2}{*}{ df } & \multirow[b]{2}{*}{ Sig. } & \multirow[b]{2}{*}{$\operatorname{Exp}(B)$} & \multicolumn{2}{|c|}{$95,0 \%$ C.I.for EXP(B) } \\
\hline & & & & & & & & Lower & Upper \\
\hline Step & DCAOC & 1,892 & ,913 & 4,290 & 1 & ,038 & 6,630 & 1,107 & 39,710 \\
\hline 1 & Constant & $-8,279$ & 4,082 & 4,114 & 1 & ,043 &, 000 & & \\
\hline
\end{tabular}

a. Variable(s) entered on step 1: DCAOC. 
ANEXO L: RESULTADO DA REGRESSÃO LOGÍSTICA - MROE

Block 0: Beginning Block

\begin{tabular}{|lll|r|r|r|}
\hline & & Score & df & \multicolumn{1}{c|}{ Sig. } \\
\hline Step 0 & Variables & MROE & 7,551 & &, 006 \\
& Overall Statistics & & 7,551 & & 1 \\
& 006 \\
\hline
\end{tabular}

Block 1: Method = Enter

\begin{tabular}{|rl|r|r|r|}
\hline & & Chi-square & \multicolumn{1}{c|}{ df } & \multicolumn{1}{c|}{ Sig. } \\
\hline Step 1 & Step & 8,643 & 1 &, 003 \\
& Block & 8,643 & 1 &, 003 \\
& Model & 8,643 & 1 &, 003 \\
\hline
\end{tabular}

\begin{tabular}{|l|r|r|r|}
\hline Step & $\begin{array}{c}-2 \text { Log } \\
\text { likelihood }\end{array}$ & $\begin{array}{c}\text { Cox \& Snell } \\
\text { R Square }\end{array}$ & $\begin{array}{c}\text { Nagelkerke } \\
\text { R Square }\end{array}$ \\
\hline 1 & 35,593 &, 237 &, 316 \\
\hline
\end{tabular}

\begin{tabular}{|c|c|c|c|}
\hline Step & Chi-square & $\mathrm{df}$ & Sig. \\
\hline 1 & 10,988 & 8 & ,202 \\
\hline
\end{tabular}

\begin{tabular}{|ll|r|r|r|r|r|}
\hline & & \multicolumn{2}{|c|}{ VARDEP $=, 00$} & \multicolumn{2}{c|}{ VARDEP $=1,00$} & \multirow{2}{*}{ Total } \\
\cline { 2 - 6 } & & Observed & Expected & Observed & Expected & \multicolumn{2}{|c}{ Tot } \\
\hline Step & 1 & 2 & 2,773 & 1 &, 227 & 3 \\
1 & 2 & 2 & 2,535 & 1 &, 465 & 3 \\
& 3 & 3 & 2,296 & 0 &, 704 & 3 \\
& 4 & 3 & 2,004 & 0 &, 996 & 3 \\
& 5 & 3 & 1,724 & 0 & 1,276 & 3 \\
6 & 2 & 1,573 & 1 & 1,427 & 3 \\
& 7 & 1 & 1,249 & 2 & 1,751 & 3 \\
& 1 &, 995 & 2 & 2,005 & 3 \\
& 9 & 0 &, 890 & 3 & 2,110 & 3 \\
& 10 & 0 &, 961 & 5 & 4,039 & 5 \\
\hline
\end{tabular}

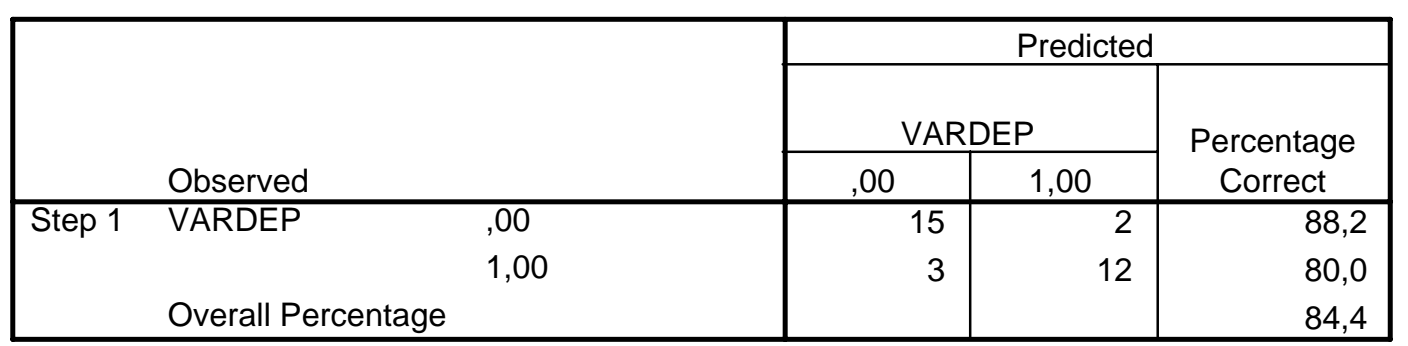

\begin{tabular}{|c|c|c|c|c|c|c|c|c|c|}
\hline & \multirow[b]{2}{*}{ B } & \multirow[b]{2}{*}{ S.E. } & \multirow[b]{2}{*}{ Wald } & \multirow[b]{2}{*}{$d f$} & \multirow[b]{2}{*}{ Sig. } & \multirow[b]{2}{*}{$\operatorname{Exp}(B)$} & \multicolumn{2}{|c|}{ 95,0\% C.I.for EXP(B) } \\
\hline & & & & & & & & Lower & Upper \\
\hline Step & MROE &,- 017 & ,007 & 5,919 & 1 & ,015 & ,983 & 970 & 997 \\
\hline & Constant & ,926 & ,572 & 2,626 & 1 & 105 & 2,525 & & \\
\hline
\end{tabular}

a. Variable(s) entered on step 1: MROE. 